\title{
Unsaturated Fractured Rock Characterization Methods and Data Sets at the Apache Leap Tuff Site
}

Manuscript Completed: June 1990

Date Published: August 1990

Prepared by

T. C. Rasmussen, D. D. Evans, P. J. Sheets, J. H. Blanford

Department of Hydrology and Water Resources College of Engineering and Mines

University of Arizona

Tucson, AZ 85721

Prepared for

Division of Engineering

Office of Nuclear Regulatory Research

U.S. Nuclear Regulatory Commission

Washington, DC 20555

NRC FIN D1662 


\section{OTHER REPORTS IN THIS SERIES}

Evans, D.D., 1983, Unsaturated Flow and Transport Through Fractured Rock Related to High-Level Waste Repositories, NUREG/CR-3206, 231 pp.

Schrauf, T.W. and D.D. Evans, 1984, Relationship Between the Gas Conductivity and Geometry of a Natural Fracture, NUREG/CR-3680, 131 pp.

Huang, C. and D.D. Evans, 1985, A 3-Dimensional Computer Model to Simulate Fluid Flow and Contaminant Transport Through a Rock Fracture System, NUREG/CR-4042, 109 pp.

Green, R.T. and D.D. Evans, 1987, Radionuclide Transport as Vapor Through Unsaturated Fractured Rock, NUREG-CR-4654, 163 pp.

Rasmussen, T.C. and D.D. Evans, 1987, Unsaturated Flow and Transport Through Fractured Rock - Related to High-Level Waste Repositories, NUREG/CR-4655, $.474 \mathrm{pp}$.

Yeh, T.C.J., T.C. Rasmussen and D.D. Evans, 1988, Simulation of Liquid and Vapor Movement in Unsaturated Fractured Rock at the Apache Leap Tuff Site: Models and Strategies, NUREG/CR-5097, 73 pp.

Weber, D.S. and D.D. Evans, 1988, Stable Isotopes of Authigenic Minerals in Variably-Saturated Fractured Tuff, NUREG/CR-5255, 70 pp.

Rasmussen, T.C. and D.D. Evans, 1989, Fluid Flow and Solute Transport Modeling Through Three-Dimensional Networks of Variably Saturated Discrete Fractures, NUREG/CR-5239, $193^{\text {ppp. }}$

Chuang, Y., W.R. Haldeman, T.C. Rasmussen, and D.D. Evans, 1990, Laboratory Analysis of Fluid Flow and Solute Transport Through a Variably Saturated Fracture Embedded in Porous Tuff, NUREG/CR-5482, 328 pp. 


\section{DISCLAIMER}

This report was prepared as an account of work sponsored by an agency of the United States Government. Neither the United States Government nor any agency thereof, nor any of their employees, make any warranty, express or implied, or assumes any legal liability or responsibility for the accuracy, completeness, or usefulness of any information, apparatus, product, or process disclosed, or represents that its use would not infringe privately owned rights. Reference herein to any specific commercial product, process, or service by trade name, trademark, manufacturer, or otherwise does not. necessarily constitute or imply its endorsement, recommendation, or favoring by the United States Government or any agency thereof. The views and opinions of authors expressed herein do not necessarily state or reflect those of the United States Government or any agency thereof. 


\section{DISCLAIMER}

\section{Portions of this document may be illegible in electronic image products. Images are produced from the best available original document.}




\section{ABSTRACT}

Performance assessment of high-level nuclear waste containment feasibility requires representative values of parameters as input, including parameter moments, distributional characteristics, and covariance "structures between parameters. To meet this need, characterization methods and data sets for interstitial, hydraulic, pneumatic and thermal parameters for a slightly welded fractured tuff at the Apache Leap Tuff site situated in central Arizona are reported in this document. The data sets include the influence of matric suction on measured parameters. Spatial variability is investigated by sampling along nine boreholes at regular distances. Laboratory parameter estimates for 105 core segments are provided, as well as field estimates centered on the intervals where the core segments were collected. Measurement uncertainty is estimated by repetitively testing control samples. 


\section{TABLE OF CONTENTS}

Page

0. Executive Summary ................... xiii

1. Introduction .................... 1

1.1 Objective .................. 1

1.2 Field Site Description .............. 2

2. Interstitial Characterization Parameters . . . . . . . 9

2.1 Matrix Interstitial Properties . . . . . . . . . 9

2.1 .1 Bulk Density ....... . . . . . . . 9

2.1.2 Effective Porosity ............ 10

2.1.3 Skeletal Density .............. 12

2.1.4 Pore Surface Area ............... 13

2.1.5 Pore Size Distribution ............ 14

2.2 Fracture Interstitial Properties........... 16

2.2.1 Location ................ 16

2.2.2 Density and Spacing ............ 16

2.2 .3 Orientation ............. 17

3. Hydraulic Characterization Parameters . . . . . . . . . 19

3.1 Matrix Hydraulic Properties . . . . . . . . . . 19

3.1.1 Saturated Hydraulic Conductivity. . . . . . 19

3.1.2 Moisture Characteristic Curve ......... 20

3.1.3 Unsaturated Hydraulic Conductivity . . . . . 24

3.2 Field Hydraulic Properties .............. . 26

3.2.1 Field Hydraulic Conductivity . . . . . . 26

3.2.2 Field Water Content............ 27

4. Pneumatic Characterization Parameters .......... 33

4.1 Matrix Pneumatic Permeability . . . . . . . . . 33

4.2 Field Pneumatic Properties ............. 35

5. Thermal Characterization Parameters . . . . . . . . . 38

5.1 Matrix Thermal Properties .. . . . . . . . . . 38

5.2 Field Thermal Properties... . . . . . . . . 41

6. Quantification of Parameter Uncertainties . . . . . . . 42

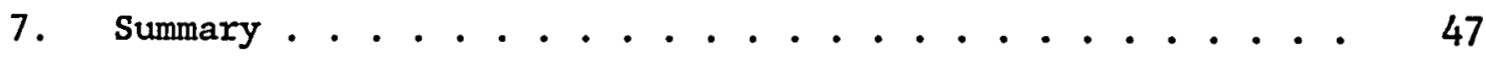

8. References ................... 48

A. Appendix . . . . . . . . . . . . . . 50 


\section{LIST OF FIGURES}

Figure

Page:

1 Site location map for the Apache Leap Tuff site in central Arizona.

2 Aerial view of ALTS and surrounding terrain showing extensive fracture network.

3 Borehole configuration showing inclined boreholes and $30 \mathrm{~m}$ by $50 \mathrm{~m}$ plastic cover.

4 Core sample locations with associated two letter identification label.

5 Diagram of three borehole core segments and uses.

6 Permeameter used to obtain saturated hydraulic conductivity for large core segments.

7 Laboratory apparatus for obtaining unsaturated hydraulic conductivity using the outflow method.

8 Location of neutron water content calibration boreholes.

9 Diagram of field single hole air injection experiment: 37

10 Apparatus used to es'imate water content dependent thermal properties. 


\section{LIST OF TABLES}

Table

Page

1 Sumnary of bulk density values obtained from core segments at the Apache Leap Tuff Site.

2 Summary of effective porosity values obtained from core segments at the Apache Leap Tuff site.

3 Summary of skeletal density values obtained from core segments at the Apache Leap Tuff Site.

4 Summary of pore area values obtained from medium core segments at the Apache Leap Tuff Site.

5 Summary of cumulative intrusion volume as a function of equivalent pore diameter obtained from medium core segments at the Apache Leap Tuff Site.

6 Summary of fracture density and orientation obtained from borehole cores at the Apache Leap Tuff Site.

7 Summary of saturated hydraulic conductivity values obtained from large core segments at the Apache Leap Tuff site.

8 Summary of laboratory moisture characteristic curve values obtained from pressure extraction vessel and Tempe Pressure Cells using large core segments and from thermocouple psychrometer data using small core segments at the Apache Leap Tuff site. Mean wetting curves for 10 large core segments are also presented. Also shown are summary statistics for Van Genuchten moisture characteristic curve function.

9 Summary of unsaturated hydraulic conductivity values obtained from large core segments at the Apache Leap Tuff Site.

10 Summary of field determined outflow rates and saturated hydraulic conductivity values at the Apache Leap Tuff site.

11 Observed neutron counts with depth at two callbration bore holes, Apache Leap Tuff site.

12 Results for neutron calibration borehole tests, Apache Leap Tuff Site.

13 Field water contents for various dates at the Apache Leap Tuff site.

vii . 


\section{LIST OF TABLES (Continued)}

Table

Page

14 Summary of laboratory air permeabilities. 34

15 Summary of laboratory determined Klinkenberg slip flow 35 coefficient.

16 Summary of field determined air permeability. $\quad 36$

17 Summary of laboratory thermal conductivity. 40

18 Oven dry air permeability for parameter variation 43 estimation.

19 Saturated hydraulic permeability for parameter variation 44 estimation.

20 Moisture characteristic curves for parameter variation 45 estimation.

21 Unsaturated hydraulic conductivity values for parameter 46 variation estimation.

Al Local coordinates in meters of borehole casing lip, ground 50 surface and borehole bottom at the Apache Leap Tuff Site.

A2 Local coordinates in meters of borehole sample locations at 51 the Apache Leap Tuff Site.

A3 Bulk and skeletal densities for three core segment sizes. 52

A4 Effective porosity for three core segment sizes and pore 55 area values for small core segment sizes at 105 locations at the Apache Leap Tuff Site.

A5a Equivalent pore diameters (in micrometers) for mercury 58 intrusion injection pressures.

A5b Cumulative volumetric porosity determined from mercury 69 intrusion volumes for 105 medium core segments.

A6 Fracture geometric information obtained from oriented dri11 80 core. 


\section{LIST OF TABLES (Continued)}

Table

Page

A7 Fracture density values obtained from borehole cores at the Apache Leap Tuff Site.

A8 Saturated hydraulic conductivity (Ksat) obtained from 105

large core segments at the Apache Leap Tuff Site.

A9a Laboratory moisture characteristic curves for 105 large. core segments as a function of matric suction using pressure extractor.

A9b Laboratory moisture characteristic curves for 105 small segments using themocouple psychrometer device.

A9c Laboratory moisture characteristic curves for 105 large core segments as a function of matric suction using Tempe Pressure cells.

A9d Laboratory moisture characteristic curves for 10 large core segments as a function of matric suction for wetting phase.

A9e Van Genuchten moisture characteristic curve function parameters. Least squares estimate using relative saturation objective function and a constant $n$-value for all samples. Optimal parameter estimates obtained when residual saturation is zero and when the $n$-parameter is equal to 1.26 .

A10 Laboratory determined unsaturated hydraulic conductivity values for large core segments obtained using outflow method.

All Field determined saturated hydraulic conductivity values at the Apache Leap Tuff Site using three methods:

(1) Philip, (2) Glover, and (3) Dachler.

A12 Outflow rates during borehole flooding experiments.

A13 Field volumetric water content in percent determined from neutron count data.

A14 Laboratory unsaturated air permeability.

A15 Klinkenberg coefficients obtained from laboratory air/water permeability ratios for 105 large core segments. 


\section{LIST OF TABLES (Continued)}

Table

Page

A16 Field observed flow rates and interpreted air permeability. 117

A17 Laboratory-estimated thermal conductivity and dry

122 rock specific heat for saturated, variably saturated and oven-dried large core segments.

A18 Field observed temperatures in Borehole Y3. 


\section{$\because$ ACKNOWLEDGEMENTS: $\because \because$,}

Professor Daniel D. Evans was responsible for project management and supervision. Dr. Todd C. Rasmussen assisted in project management and was responsible for the preparation of this manuscript. Priscilla Sheets performed much of the laboratory analysis, with contributions by Gerald Vogt for the mercury intrusion. analysis and Guo. Zede for the design of the thermal properties procedure. Jim Blanford was responsible for much of the field testing program, with contributions by. Vince Tidwell. This research was funded by the US Nuclear Regulatory Commission (USNRC) under contract number. NRC-04-86-114. The USNRC: project monitor was. Thomas J. Nicholson. Additional funding was provided by the Center for Nuclear Waste Regulatory Analysis (CNWRA) under subcontract number 65626. The CNWRA project monitor was Dr. John Russell. 


\section{EXECUTIVE SUMMARY}

The feasibility of long-term containment of radioactive and toxic wastes in geologic media is the concern of regulatory agencies empowered with the responsibility of assuring the continued health and safety of the public. In particular, the U.S. Nuclear Regulatory Commission (USNRC) has promulgated regulations which require that high-level nuclear wastes (HLW), consisting chiefly of spent fuel from nuclear reactors, be stored in a safe manner. The feasibility of HLW storage in unsaturated fractured rock remains uncertain, and data bases which can be used to determine the feasibility of long-term containment are lacking.

In 1986, USNRC funded a field and laboratory program (Contract NRC-0486-114, FIN D1662) whose purpose was to provide data sets related to the interstitial, hydraulic, pneumatic and thermal properties of unsaturated fractured rock. The purpose of these data sets was to provide USNRC with estimates of parameter uncertainties related to measurement errors and geologic variability. Task 1 of the program was to determine the important contributors to measurement errors and uncertainties associated with hydrologic instrumentation and measurement in the unsaturated zone. An additional purpose of the data sets will be the application to the INTRAVAL program to evaluate numerical models of flow and transport in unsaturated fractured rock systems.

To meet the needs specified by USNRC, a field site in unsaturated fractured tuff near the town of Superior in central Arizona, termed the Apache Leap Tuff Site (ALTS), was selected for acquiring characterization data sets. Boreholes were drilled at ALTS to a maximum depth of $30 \mathrm{~m}$ and at a vertical angle of $45^{\circ}$ for the purpose of intersecting vertical fractures at the site. Over $270 \mathrm{~m}$ of oriented core were collected from the nine boreholes. Characterization parameters for core segments of three sizes collected at approximately three meter intervals have been estimated for 105 samples. The three core segments sizes are:

- $1 \mathrm{~cm}$ long by $1 \mathrm{~cm}$ in diameter;

- $2.5 \mathrm{~cm}$ long by $2.5 \mathrm{~cm}$ in diameter; and

: $5 \mathrm{~cm}$ long by $6 \mathrm{~cm}$ in diameter.

Field parameters are obtained at the same three meter interval centered on the position where the core segments were collected. Data obtained from field and laboratory tests are of the following types:

- Rock matrix interstitial properties, consisting of bulk and skeletal densities, effective porosity, pore surface area, and pore size distributions collected from the core segments;

- Rock fracture interstitial properties, consisting of fracture location, density, and orientation, collected from oriented cores;

- Rock matrix hydraulic properties, consisting of the laboratory saturated hydraulic conductivity, moisture characteristic curves, and unsaturated 
hydraulic conductivity curves collected from core segments, as well as field saturated hydraulic conductivity determined from borehole interval testing.

- Time series of field borehole water contents derived from neutron count measurements;

- Water content dependent pneimatic permeability of unfractured rock cores for a range of water contents, as well as the air permeability of fractured rock at ambient water contents at the ALTS; and

- Water content dependent thermal conductivity and specific heat of unfractured rock core segments.

Summary statistical data are presented for the parameters, including the mean, coefficient of variation, minimum, median and maximum values. The data were collected either from 105 core segments located at approximately three meter intervals, or from borehole test intervals which test three meter intervals coincident with the core segment locations.

For the 105 samples tested, bulk densities of the largest segments lie between 1.86 and $2.20 \mathrm{Mg} / \mathrm{m}^{3}$, with an arithmetic average of $2.10 \mathrm{Mg} / \mathrm{m}^{3}$ and a coefficient of variation of 38 . The effective porosity of the largest segments ranges between 14.30 and 27.51 percent volumetric, with a mean of 17.54 percent and a variation of $13 \%$. Mean skeletal density is $2.55 \mathrm{Mg} / \mathrm{m}^{3}$ with a variation of 28 . Mean pore area of the medium sized segments is $3.466 \mathrm{~m}^{2} / \mathrm{gm}$ with a variation of 658 . For the 105 borehole intervals examined, the fracture density ranged from 0 to 4.33 fractures per meter, with a mean of 0.77 and a coefficient of variation of 1088 .

The relative saturation of rock core segments decreases from a mean of 95.5 percent at $10 \mathrm{kPa}$, to 70.2 percent at $100 \mathrm{kPa}$, to 47.5 percent at $1000 \mathrm{kPa}$, to 22.2 percent at $10,000 \mathrm{kPa}$, to 12.8 at $100,000 \mathrm{kPa}$. Results of hydraulic testing of core segments indicate a mean saturated hydraulic conductivity of $21.31 \times 10^{-9} \mathrm{~m} / \mathrm{s}$ with a coefficient of variation of 3018 and a range of approximately three orders of magnitude. The unsaturated hydraulic conductivity means at $10,25,50$ and $100 \mathrm{kPa}$ are $3.346,1.475$, 0.908 , and $0.364 \times 10^{-9} \mathrm{~m} / \mathrm{s}$. Field estimates of saturated hydraulic conductivity range from a mean of 29.19 to $59.42 \times 10^{-9} \mathrm{~m} / \mathrm{s}$ depending upon the method used to interpret the field tests. The variation of the field estimate is approximately 7008 and ranges over five orders of magnitude. Field water contents are estimated using neutron count data calibrated in the field at two locations with different water contents. Field volumetric water contents range from a low of 9.53 percent to a high of 18.75 percent on different dates.

Data sets for core segments yield an oven-dried air permeability of $57.12 \mathrm{x}$ $10^{-16} \mathrm{~m}^{2}$, decreasing to half that value at approximately $100 \mathrm{kPa}$. The laboratory air permeability also displays great variability, ranging over three orders of magnitude with a coefficient of variation of 2728 . A difference between air and water permeability is explained by the Klinkenberg effect. Measured field air permeabilities are generally less than oven-dried core segments. 
A mean saturated thermal conductivity of $1.821 \mathrm{~J} / \mathrm{ms}^{\circ} \mathrm{C}$ is observed for large core segments, with a coefficient of variation of 10.78. The mean thermal conductivity for oven-dried samples is $1.266 \mathrm{~J} / \mathrm{ms}^{\circ} \mathrm{C}$, with a coefficient of variation of 11.58 . For the thermal conductivity parameter, the influence of relative saturation is substantially less than for the hydraulic

conductivity. A thermal conductivity of $1.95 \mathrm{~J} / \mathrm{ms}^{\circ} \mathrm{C}$ and a heat capacity of $2.4 \times 10^{6} \mathrm{~J} / \mathrm{m}^{30} \mathrm{C}$ provide a good fit to field observations of thermal responses to an annual thermal cycle.

Characterization parameters demonstrate substantial spatial variability, with some parameters evidencing variations over many orders of magnitude. In particular, the saturated and unsaturated hydraulic conductivities and the air permeability parameters range over at least three orders of magnitude. Other parameters have less significant variation, such as the bulk density and thermal conductivity which range over just ten percent of the mean. 


\section{Introduction}

A program to characterize fluid flow and solute transport in unsaturated fractured rock related to high-level waste repositories is being conducted by the University of Arizona, Department of Hydrology and Water Resources under the sponsorship of the U.S. Nuclear Regulatory Commission (USNRC). The activities are conducted in support of USNRC's licensing actions with respect to the site characterization program conducted by the U.S. Department of Energy at the candidate high level repository site at Yucca.

Mountain, Nevada. Characterization is being performed with respect to the fluid, heat, and solute transport properties of fractured tuffaceous rock.

An earlier document (Yeh et al., 1988) described proposed simulation models and modeling strategies to be used for investigating liquid and vapor movement in unsaturated fractured rock. Other documents (Evans, 1983; Rasmussen and Evans, 1987) which focused on characterization methods for unsaturated fractured rock contain additional details regarding characterization strategies. This document focuses on other aspects of the characterization process for use in parameterizing, calibrating and validating models of fluid, heat and solute transport;

- Procedures necessary for obtaining characterization data sets;

- Representative data sets for the Apache Leap site; and

- Limited interpretations based on gathered data sets.

Characterization methods for interstitial, hydraulic, pneumatic, and thermal properties under conditions of variable saturation in both the rock matrix and embedded fractures are presented using laboratory and field techniques. This report summarizes the properties for a regular sampling grid of 105 points, both in the laboratory for core segments, and in the field for corresponding intervals. A description of the field test, site where the samples were collected and the intervals were tested is presented in this chapter. The second chapter describes the interstitial properties of the matrix and fractures. Chapter three presents the hydraulic properties, while chapters four and five present the pneumatic and thermal properties, respectively. Chapter six presents data summarizing the precision of the laboratory testing techniques employed.

\subsection{Objective}

One objective of the characterization process is to understand the mechanisms which govern solute and contaminant transport through unsaturated fractured rock. The objective of this document is to provide data sets suitable for the characterization of the interstitial, hydraulic, pneumatic and thermal properties of unsaturated fractured rock at a field site located in tuff. By quantifying these properties, analytic and numeric models can be employed to forecast solute transport behavior. 


\subsection{Field Site Description}

To meet the objectives of the research program, a field site has been selected in unsaturated fractured tuff. The field site, named the Apache Leap Tuff Site (ALTS) is located near Superior, Arizona, approximately 160 $\mathrm{km}$ north of Tucson, Arizona, (Figure 1). ALTS lies in the uppermost part of an approximately $20 \mathrm{~m} . \mathrm{y}$. old tuff formation which varies from a slightly welded unit on top (where the Apache Leap site is'situated) through a moderately welded unit below, to a densely welded unit near the base of the formation. The base of the unit is composed of a non-welded unit underlying a vitrophyre. The entire formation was originally $600 \mathrm{~m}$ thick on average, but has weathered to an average thickness of approximately $150 \mathrm{~m}$ (Peterson, 1961, 1968).

An aerial view of the Apache Leap site is shown in Figure 2. The exposed rock at the site is the uppermost unit of a sequence of ash-flow tuff sheets. At the site, the tuff is over $300 \mathrm{~m}$ thick and grades from densely welded near the bottom to slightly welded at the top with the different units dipping to the east. In addition to the volcanic groundmass, the tuff contains various mixtures of phenocrysts, pumice fragments, and entrained foreign rocks. Peterson (1968) gives a detailed description of the origin and spatial characteristics of the tuff; which covers an area of $1000 \mathrm{~km}^{2}$ and has a maximum depth of $600 \mathrm{~m}$. About one kilometer to the west of the Apache Leap site is a $600-\mathrm{m}$ escarpment and immediately to the north there is a $200-\mathrm{m}$ drop-off. The rest of the surface is dissected by ephemeral streams. The topography of the experimental area is nearly level compared to the surroundings.

Linear fracture traces are evident in Figure 2 with some extending through the study site. A slight depression with a thin layer of unconsolidated material and sparse vegetation normally occurs along surface fracture traces. These conditions provide an important water reservoir for water intake by the fractures (Yeh et al., 1988). The annual average precipitation at the $1200-\mathrm{m}$ elevation site is approximately $640^{\circ} \mathrm{mm}$. The precipitation occurs in two seasons, from mid-July to late-September (characterized by high-intensity, short-duration thunderstorms during periods of high temperature and evapotranspiration demand), and from mid-November to late-March (characterized by longer duration and lower intensity storms during cooler periods with much lower evapotranspiration demands) (Yeh et al., 1988). The regional ground-water level has been lowered by mine dewatering operations to a depth of over $1500 \mathrm{~m}$ below surface.

To obtain parameters for the rock matrix and the fractures at the site, three sets (named $\mathrm{X}-, \mathrm{Y}-$, and $\mathrm{Z}$-series) of three boreholes (named 1,2 , and 3) each were installed with each borehole at a $45^{\circ}$ angle from the horizontal. A diamond bit drill was used for installing the boreholes. The drill was also used to cut a $6.35-\mathrm{cm}$ diameter core. A specialiy designed scribing technique provided an orientation mark every 1.52 or $3.05 \mathrm{~m}$ along the borehole. Nearly 100 percent core orientation for all boreholes was obtained by using the scribe marks. Approximately $270 \mathrm{~m}$ of oriented core were obtained. 




Figure 1: Site location map for the Apache Leap Tuff Site in central Arizona. 


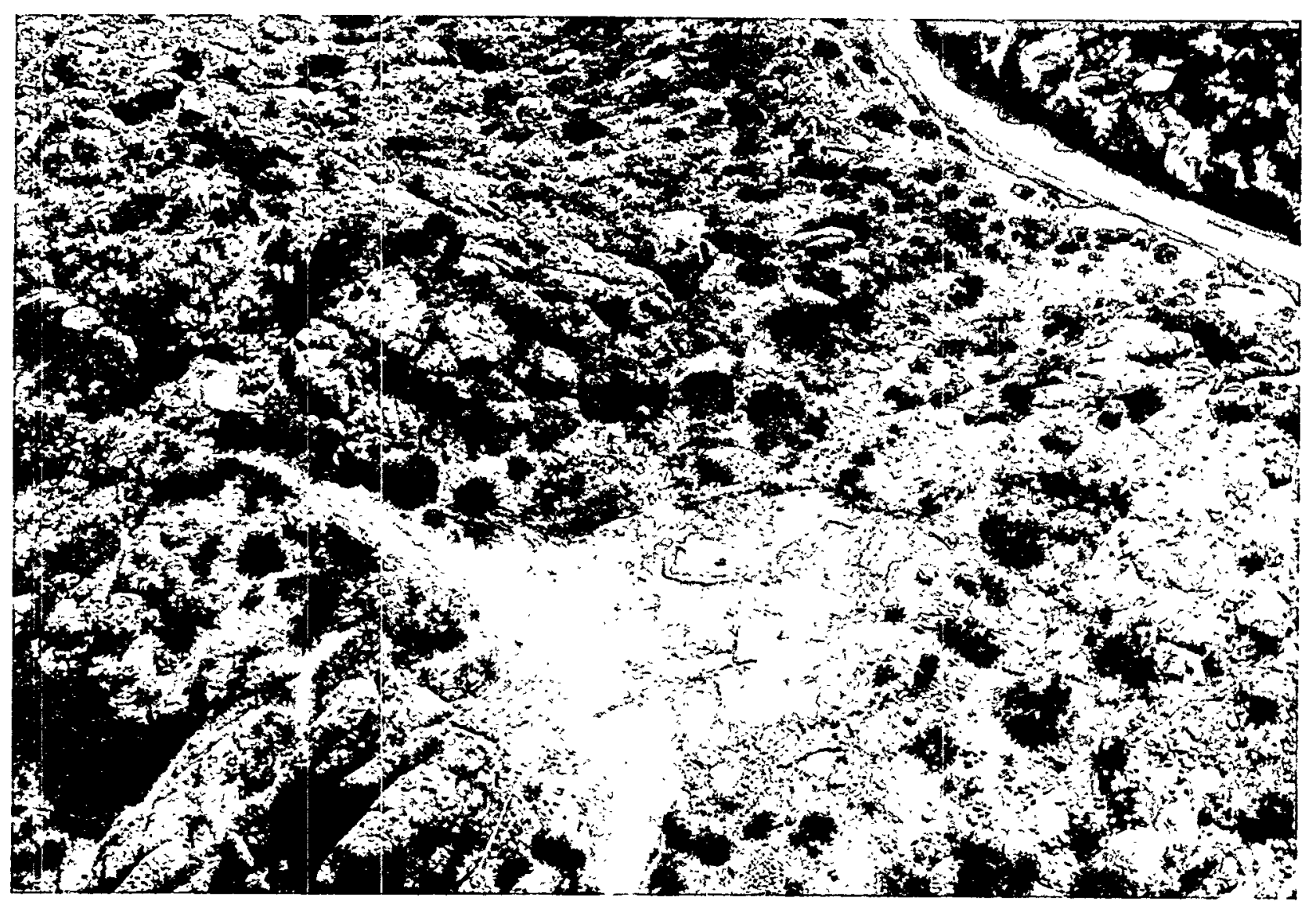

Figure 2: Aerial view of ALTS and surrounding terrain showing extensive fracture network. 
The $10-\mathrm{cm}$ diameter boreholes of each set are in a vertical plane and offset by $10 \mathrm{~m}$ as shown in Figure 3 . The sets are parallel and offset by $5 \mathrm{~m}$. Sets $X$ and $Y$ dip to the west while set $Z$ dips to the east. The variable lengths, approximately 15,30 and $45 \mathrm{~m}$, provide fracture-borehole intersections for individual fractures at different depths below the surface. The double letter designations in Figure 4 indicate common core sampling and field measurement locations.

Characterization data sets for the tuff matrix were obtained from the oriented cores using sections cut from the core at approximately three meter increments. Three segments are removed from each section, as indicated in Figure 5. The segments are labeled 'large' $(5 \mathrm{~cm}$ long by $6 \mathrm{~cm}$ diameter), 'medium' ( $2.5 \mathrm{~cm}$ long by $2.5 \mathrm{~cm}$ diameter) and 'small' (1 cm long by $1 \mathrm{~cm}$ diameter) to differentiate between the three segments. Table Al in the appendix presents geometric relationships between the boreholes and a local coordinate system, while Table A2 presents the estimated $(x, y, z)$ coordinates for each of the samples. All coordinates are local to the site, with the base elevation arbitrarily set to the elevation of the Iip of the casing of Borehole XI.

The nine boreholes provide ready access for various in situ measurements while the cores provide information on fracture spacing and orientation as well as samples for measuring matrix properties in the laboratory. To control water inputs (e.g., precipitation) and outputs (e.g., evaporation) at the test area, the area was covered with plastic to a distance of $10 \mathrm{~m}$ in all directions beyond the boreholes for a total area of $1500 \mathrm{~m}^{2}$. Surface water is directed away from the site to prevent wetting of the region around the boreholes. 

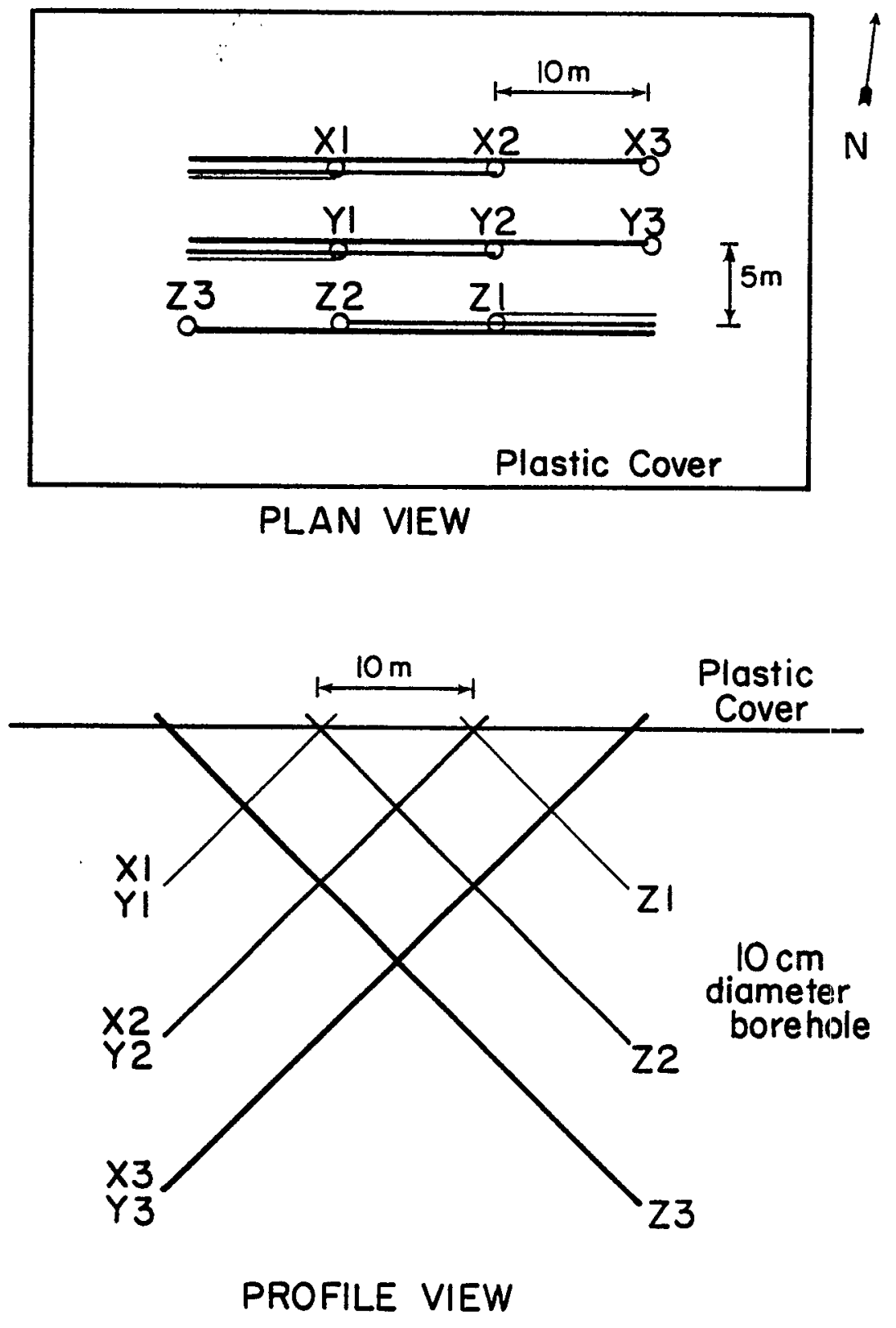

Figure 3: Borehole configuration showing inclined boreholes and $30 \mathrm{~m} \mathrm{x} 50$ m plastic cover. 


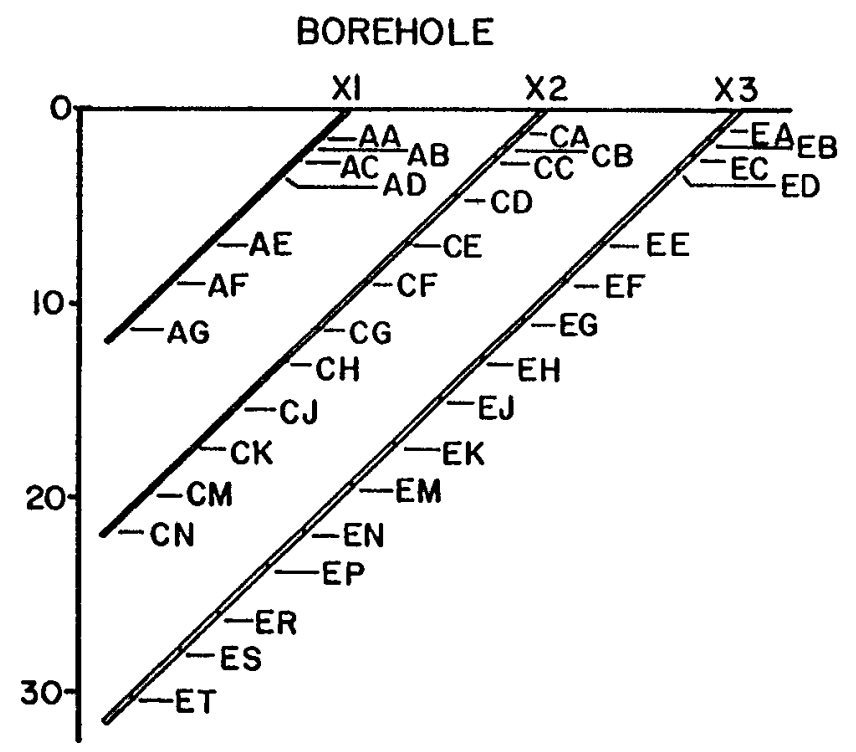

\section{APACHE LEAP TUFF SITE CORE SAMPLE LOCATIONS}
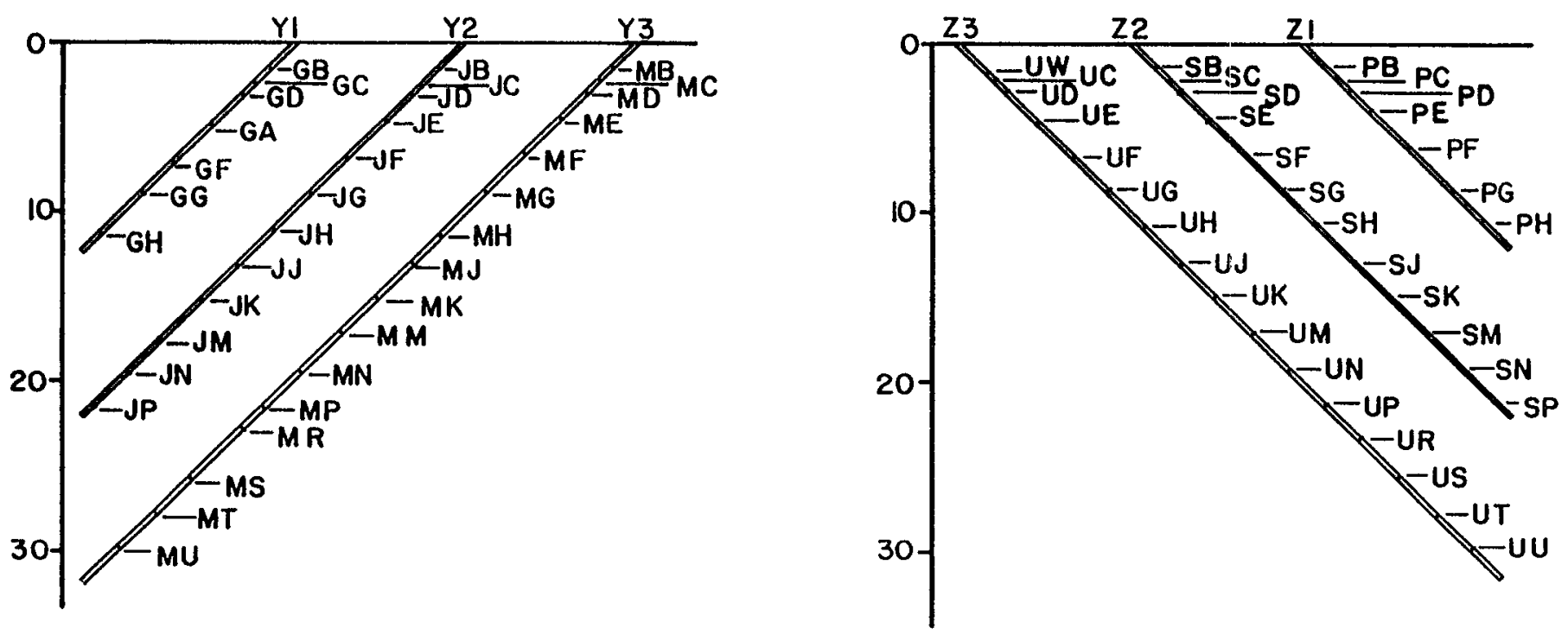

Figure 4: Core sample locations with associated two letter identification label. 


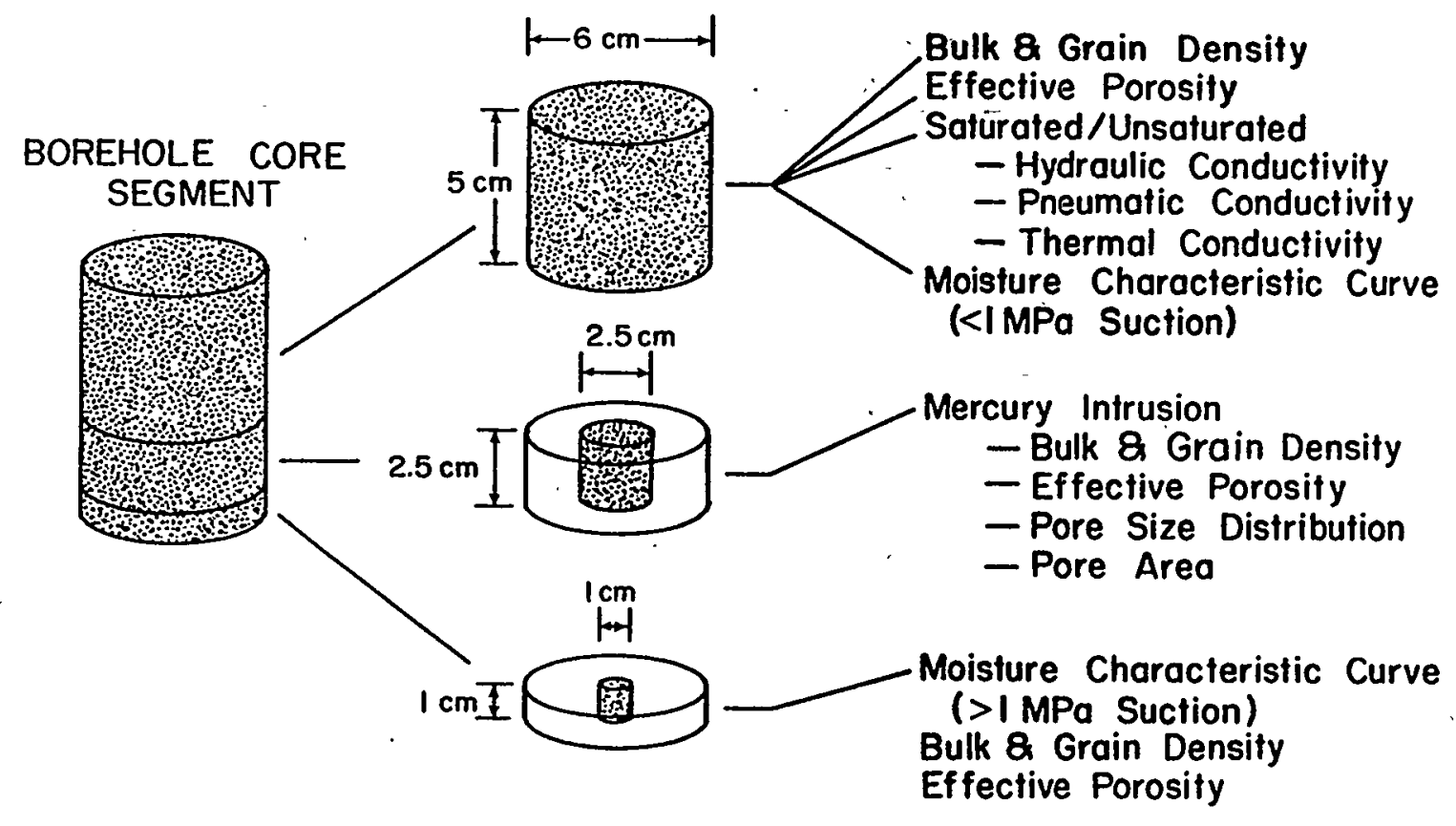

Figure 5: Diagram of three borehole core segments and uses. 


\section{Interstitial Characterization Parameters}

Characterization of the rock interstitial properties is performed using oriented cores obtained during borehole drilling. The cores were extracted during the drilling of the $10 \mathrm{~cm}$ diameter boreholes, and measure $6.34 \mathrm{~cm}$ in diameter for the $\mathrm{X}$-boreholes, and $6.08 \mathrm{~cm}$ in diameter for the $\mathrm{Y}$ - and z-boreholes. Approximately $270 \mathrm{~m}$ of core were obtained from the nine boreholes. Properties of the rock matrix were obtained using a regular sampling system, while fracture parameters were obtained by performing an inventory of all apparent fissures observed in the cores. A description of the matrix and fracture parameters follows, along with data sets and the procedures employed to collect the data.

\subsection{Matrix Interstitial Properties}

Interstitial properties of the rock matrix are obtained at 105 sample locations using rock core samples of the three segment sizes described above. The measured interstitial properties of the core segments include the bulk density, skeletal density, effective porosity, and pore area. The pore area is available only for the medium segment, while the other properties are reported. for the three segment sizes.

\subsubsection{Bulk Density}

The bulk density is the dry rock mass per unit volume, determined by oven drying the rock sample at $105^{\circ} \mathrm{C}$ until a constant mass is obtained, weighing the rock segment to determine its mass, and then measuring the dimensions of the segment for computing its volume if it is a regular solid:

$$
\rho_{b}=M_{d} / \mathrm{V}
$$

where

$\rho_{\mathrm{b}}$ segment bulk density, $\mathrm{Mg} / \mathrm{m}^{3}$;

$\mathrm{M}_{\mathrm{d}}$ segment dry mass, $\mathrm{Mg}$; and

$\mathrm{V}$ segment volume, $\mathrm{m}^{3}$.

For segments that are not regular, the volume is determined using Archimedes' principle:

$$
\mathrm{V}=\mathrm{M}_{\mathrm{t}} / \rho_{\mathrm{w}}
$$

where

$M_{t}$ tare mass of sample suspended under water with respect to initial mass of water, $\mathrm{kg}$; and

$\rho_{w}$ density of water, $\mathrm{Mg} / \mathrm{m}^{3}$.

The tare mass of the suspended segment is determined by first saturating the segment by placing the segment in a vacuum chamber for a day and then introducing a sterile, $0.001 \mathrm{M} \mathrm{CaSO}_{4}$ solution of previously deionized water into the chamber (which is still under a vacuum) and allowing the segment 
to remain immersed for another day. Biological activity is prevented by adding thymol to the water. The segment is then removed from the chamber, blotted so that no free water coats the surface of the sample, suspended by a fine wire and immersed in a beaker of water which has been previously tared to zero. If significant, the mass of the fine wire can be subtracted from the tare mass by noting the depth of immersion of the fine wire and measuring the tare mass of the wire without the segment.

Equations (1) and (2) are used to determine the bulk density of the large and small segments. The bulk density of the medium segment was determined using the mercury intrusion method, which takes advantage of the nonwetting property of mercury. A rock. segment with a known dry mass is placed inside a chamber of known volume and the mass of mercury needed to fill the chamber is measured. The volume of the rock segment is calculated by subtracting the volume of intruded mercury (equal to the mass of the mercury intruded divided by the density of mercury) from the volume of the chamber. Equation (1) is used to find bulk density.

Table 1 summarizes bulk density data for all 105 samples and for all three segments. Table A3 presents bulk density data at each location within each borehole. Only moderate dispersion about the mean is evident, equal to approximately three percent of the mean value of $2.10 \mathrm{Mg} / \mathrm{m}^{3}$ for the large segment. The range of values shown in Table 1 varies with the segment size, and is between 1.75 and $2.25 \mathrm{Mg} / \mathrm{m}^{3}$. A substantial skew in the data is not evident, as noted by the similarity between the mean and median values in Table 1 . The bulk density data for the small segment is generally less than for the other segments.

Table 1: Summary of bulk density values obtained from core segments at the Apache Leap Tuff Site.

\begin{tabular}{lrrr} 
& \multicolumn{3}{c}{ BULK DENSITY $\left(\mathrm{Mg} / \mathrm{m}^{3}\right)$} \\
& small & medium & large \\
Mean & 1.99 & 2.13 & 2.10 \\
Coef. Var. & 48 & 38 & 38 \\
& 1.75 & 1.94 & 1.86 \\
Minimum & 2.00 & 2.14 & 2.12 \\
Median & 2.17 & 2.25 & 2.20
\end{tabular}

\subsubsection{Effective Porosity}

The effective porosity of the rock matrix is the volume of interconnected voids per unit volume of rock, exclusive of any isolated pores or large openings, such as fractures and sizable solution openings. The effective 
porosity is measured for the small and large segments by determining the difference in mass between a saturated segment and an oven-dried segment. The difference in mass is divided by the density of water and the volume of the segment, or:

$$
n_{e}=\left(M_{s}-M_{d}\right) / \rho_{w} V
$$

where

$\mathrm{n}_{\mathrm{c}}$ effective porosity, $\mathrm{m}^{3} / \mathrm{m}^{3}$; and

$M_{s}$ mass of saturated rock segment, $\mathrm{kg}$ :

For the medium segments, mercury is forced under pressure into the segment. The effective porosity is calculated by measuring the volume of mercury intruded into the sample and dividing by the volume of the sample and the density of mercury. The mercury intrusion method will underestimate the effective porosity because the volume of mercury intruded at the maximum pressure is less than the volume of water intruded due to the nonwetting property of mercury. Using capillary theory, rock pores and crevices with curvatures corresponding to a diameter of less than approximately $6 \mathrm{~nm}$ will not be intruded with mercury for the experimental equipment we used.

Table 2 presents a summary of effective porosity data for all three segments at all 105 sample locations, while Table A4 presents effective porosity data for each segment. The mean effective porosity varies from 14.62 to 17.50 percent, depending upon the method of analysis, with the mercury intrusion method consistently underestimating the porosity due to the non-wetting property of mercury. The variability using both methods is greater than the estimated bulk density, with the coefficient of variation ranging from 13 to 26 percent of the mean value. The range is also large, 11 to 25 percent for the small, 9 to 48 percent for the medium segment, and 14 to 28 percent for the large sêgment.

Table 2: Summary of effective porosity values obtained from core segments at the Apache Leap Tuff Site. Medium segment obtained using mercury intrusion method which underestimates effective porosity.

\begin{tabular}{lcrr} 
& \multicolumn{4}{c}{ EFFECTIVE POROSITY (8) } \\
& small & medium & large \\
Mean & 17.15 & 14.62 & 17.54 \\
Coef. Var. & $16 \%$ & 268 & $13 \%$ \\
Minimum & & & \\
Median & 11.02 & 9.18 & 14.30 \\
Maximum & 16.52 & 14.31 & 17.21 \\
& 24.73 & 47.58 & 27.51
\end{tabular}




\subsubsection{Skeletal Density}

Skeletal density, $\rho_{s}$, is a measure of the density of the rock matrix, expressed in units of $\mathrm{Mg} / \mathrm{m}^{3}$. The skeletal density is determined from the bulk density in conjunction with the effective porosity, according to the expression:

$$
\rho_{\mathrm{s}}=\rho_{\mathrm{b}} /\left(1-\mathrm{n}_{\mathrm{e}}\right)
$$

The estimated skeletal density will underestimate the true density due to the inclusion of isolated pores within the matrix. If the total porosity of the sample were available, then a more accurate estimate of the skeletal density would be possible. In spite of this bias, skeletal densities have been computed using data in Tables A3 and A4 for the three segments at all 105 core locations, and are reported in Tables 3 and A3, for summaries and individual measurements, respectively.

The mean skeletal density reported by Peterson (1961) is $2.53 \mathrm{Mg} / \mathrm{m}^{3}$ for the Apache Leap tuff samples he examined which compares favorably to the observed mean values of 2.50 to $2.55 \mathrm{Mg} / \mathrm{m}^{3}$ obtained using the medium and large segments, but compares poorly to the mean value of $2.40 \mathrm{Mg} / \mathrm{m}^{3} \mathrm{ob}$ tained using the small segments. The low value obtained from the small segment could possibly be attributed to the presence of unconnected microfractures induced during drilling. The variation in the skeletal density is low, from two to seven percent depending on the method used, with a range from 2.21 to $2.68 \mathrm{Mg} / \mathrm{m}^{3}$ excluding one anomaly.

Table 3: Summary of skeletal density values obtained from core segments at the Apache Leap Tuff Site.

\begin{tabular}{|c|c|c|c|}
\hline & $\begin{array}{l}\text { SKELETAL } \\
\text { smal1 }\end{array}$ & $\begin{array}{l}\text { DENSTTY } \\
\text { medium }\end{array}$ & $\begin{array}{c}\left(\mathrm{Mg} / \mathrm{m}^{3}\right) \\
\text { large }\end{array}$ \\
\hline $\begin{array}{l}\text { Mean } \\
\text { Coef. Var. }\end{array}$ & $\begin{array}{r}2.40 \\
38\end{array}$ & $\begin{array}{r}2.51 \\
78\end{array}$ & $\begin{array}{r}2.55 \\
28\end{array}$ \\
\hline $\begin{array}{l}\text { Minimum } \\
\text { Median } \\
\text { Maximum }\end{array}$ & $\begin{array}{l}2.23 \\
2.41 \\
2.53\end{array}$ & $\begin{array}{l}2.21 \\
2.51 \\
4.11\end{array}$ & $\begin{array}{l}2.34 \\
2.55 \\
2.68\end{array}$ \\
\hline
\end{tabular}




\subsubsection{Pore Surface Area}

The pore surface area is the interfacial area between the wetting fluid and the rock matrix, obtained using the mercury intrusion method. The medium sized segment is placed inside a penetrometer, which is then evacuated and filled with mercury. The volume of mercury added is measured gravimetrically and the volume of the sample is determined by subtracting the volume of mercury from the volume of the penetrometer. Mercury is then intruded under pressures up to $175 \mathrm{MPa}$ in predetermined increments. The volume of intruded mercury at each pressure increment is determined by measuring the change in electrical capacitance of mercury in a fill tube. The applied pressure is used to determine a pore diameter using capillary theory (Micromeritics, 1986):

$$
\mathrm{d}=4 \tau \cos (\alpha) / \mathrm{P}
$$

where

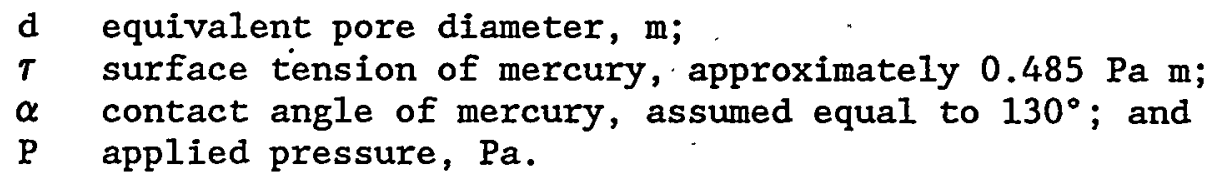

The surface area for each increment of intruded volume is calculated by noting that the total work expended per unit area of surface covered during a pressure step is equal to (Micromeritics, 1986):

$$
\mathrm{dW} / \mathrm{dA}=\tau \cos (\alpha)
$$

where $W$ is work, $J$, and $A$ is area, $\mathrm{m}^{2}$. The amount of work expended to cover pore surfaces is calculated using:

$$
d W=W_{f}-W_{1}=P_{f}\left(V_{f}-V_{0}\right)-P_{1}\left(V_{1}-V_{0}\right)=P_{f}\left(V_{f}-V_{1}\right)=P_{f} d V
$$

where

$\mathrm{W}_{1}, \mathrm{~W}_{1} \quad$ initial and final work, $\mathrm{J}$;

$\mathrm{P}_{1}, \mathrm{P}_{\mathrm{f}}$ initial and final pressure, $\mathrm{Pa}$; and

$V_{0}, V_{1}, V_{1}$ reference, initial and final volume of intruded mercury, $\mathrm{m}^{3}$.

Equation (7) assumes that the initial work is taken as the reference (i.e., $\mathrm{V}_{1}=\mathrm{V}_{\mathrm{o}}$ ). Equations (6) and (7) can be combined and, by assuming constant contact angle and surface tension, used to obtain the change in area as a function of the final pressure and the volume increment:

$$
\mathrm{dA}=P_{\mathrm{f}} \mathrm{dV} / \tau \cos (\alpha)
$$

The total area is obtained by accumulating the calculated pore area at every pressure increment. Table 4 presents summary pore surface area statistics, while Table A4 presents the results for all samples. The data indicate that the mean pore area is $3,466 \mathrm{~m}^{2} / \mathrm{kg}$ with a coefficient of variation of 65 percent, which is large relative to other matrix interstitial parameters, and ranges from 1960 to $16,510 \mathrm{~m}^{2} / \mathrm{kg}$. 
Table 4: Summary of pore area values obtained from medium core segments at the Apache Leap Tuff Site.

PORE AREA $\left(\mathrm{m}^{2} / \mathrm{kg}\right)$

Mean

Coef. Var.

3,466 .

$65 \%$

Minimum

1,960 .

Median

3,009 .

Maximum

16,510 .

\subsubsection{Pore Size Distribution}

The distribution of pore sizes can be estimated using the mercury intrusion technique described in the previous section. If a uniform contact angle and surface tension is assumed between the mercury and the rock surface, then an equivalent pore diameter can be estimated using capillary theory, i.e., Equation (5). As part of the mercury intrusion procedure, the cumulative intrusion volume is measured for each pressure increment, which can then be used to construct a distribution of intrusion volume as a function of equivalent pore diameter. Table 5 summarizes cumulative intrusion volumes. Tables $\mathrm{A5a}$ and $\mathrm{A} 5 \mathrm{~b}$ present laboratory data for all samples for the associated effective pore diameter, and incremental intrusion volumes, respectively. 
Table 5: Summary of cumulative intrusion volume as a function of equivalent pore diameter.

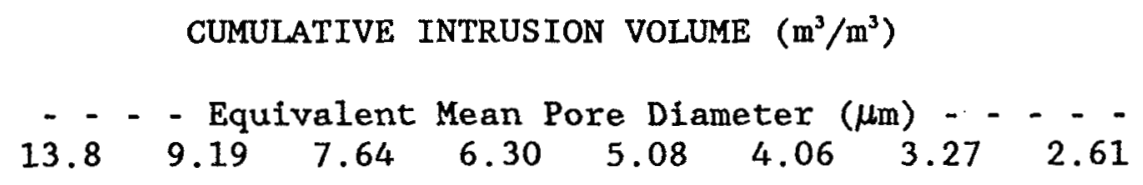

Mean

$\begin{array}{llllllllll}0.0003 & 0.0005 & 0.0011 & 0.0024 & 0.0060 & 0.0125 & 0.0213 & 0.0308\end{array}$

$\begin{array}{llllllllllllllllll}\text { Coef. Var. } & 869 & 8 & 601 & 8 & 317 & 8 & 173 & 8 & 108 & 8 & 79 & 8 & 58 & 8 & 44 & 8\end{array}$

$\begin{array}{lllllllll}\text { Minimum } & 0.0000 & 0.0000 & 0.0000 & 0.0000 & 0.0000 & 0.0000 & 0.0000 & 0.0000\end{array}$

$\begin{array}{llllllllll}\text { Median } & \quad 0.0000 & 0.0002 & 0.0004 & 0.0009 & 0.0032 & 0.0106 & 0.0205 & 0.0310\end{array}$

$\begin{array}{llllllllll}\text { Maximum } & 0.0295 & 0.0310 & 0.0318 & 0.0329 & 0.0346 & 0.0447 & 0.0580 & 0.0684\end{array}$

$\begin{array}{lrrrrrrrrrr}\text { Mean } & 0.0410 & 0.0487 & 0.0544 & 0.0590 & 0.0631 & 0.0666 & 0.0696 & 0.0726 \\ \text { Coef. Var. } & 36 & 36 & 35 & 8 & 35 & 8 & 34 & 33 & 32 & 32 \\ & & & & & & & & & & \\ \text { Minimum } & 0.0000 & 0.0000 & 0.0000 & 0.0000 & 0.0000 & 0.0006 & 0.0019 & 0.0029 \\ \text { Median } & 0.0426 & 0.0494 & 0.0560 & 0.0608 & 0.0643 & 0.0672 & 0.0714 & 0.0747 \\ \text { Maximum } & 0.0762 & 0.0907 & 0.1067 & 0.1154 & 0.1221 & 0.1273 & 0.1319 & 0.1356\end{array}$

$\begin{array}{cccccccc}- & - & - \text { Equivalent Mean Pore Diameter } & (\mu \mathrm{m}) & - & - \\ 2.07 & 1.65 & 1.30 & 1.03 & 0.802 & 0.627 & 0.494 & 0.385\end{array}$

$$
0.04100 .0487 \quad 0.05440 .0590 \quad 0.06310 .06660 .06960 .0726
$$

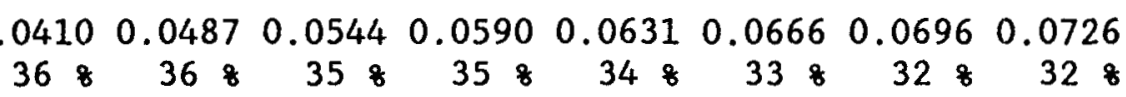

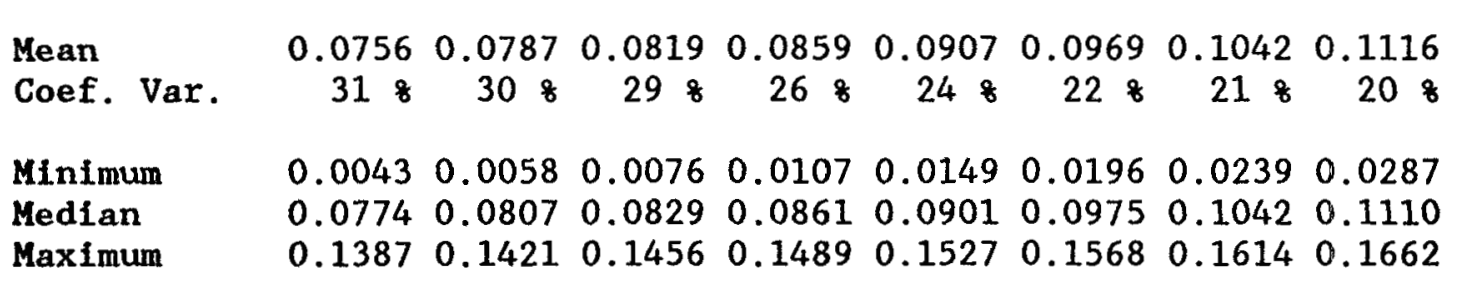

$\begin{array}{cccccccc}- & - & \text { Equivalent Mean Pore Diameter } & (\mu \mathrm{m}) & - & - & - \\ 0.302 & 0.237 & 0.187 & 0.146 & 0.115 & 0.0896 & 0.0700 & 0.0548\end{array}$

- - - Equivalent Mean Pore Diameter $(\mu \mathrm{m})$ - - - $\begin{array}{llllllllll}0.0429 & 0.0336 & 0.0262 & 0.0205 & 0.0160 & 0.0125 & 0.0098 & 0.0077\end{array}$

$\begin{array}{lrrrrrrrrrr}\text { Mean } & 0.1182 & 0.1237 & 0.1284 & 0.1327 & 0.1369 & 0.1397 & 0.1417 & 0.1428 \\ \text { Coef. Var. } & 198 & 198 & 17 & 16 & 16 & 15 & 15 & 14 & 14 \\ & & & & & & & & & \\ \text { Minimum } & 0.0345 & 0.0398 & 0.0535 & 0.0759 & 0.0871 & 0.0888 & 0.0901 & 0.0911 \\ \text { Median } & 0.1189 & 0.1250 & 0.1294 & 0.1330 & 0.1358 & 0.1389 & 0.1410 & 0.1423 \\ \text { Maximum } & 0.1710 & 0.1749 & 0.1776 & 0.1795 & 0.2023 & 0.2064 & 0.2092 & 0.2113\end{array}$ 


\subsection{Fracture Interstitial Properties}

Interstitial properties of fractures are obtained primarily from oriented cores extracted at the time of borehole construction. To orient the core, the end of the each core was scribed using a tool weighted on one side and affixed with a sharp point on the end which, when dropped down the borehole, left a mark on the stub of the core. Also, each core was noted with the depth and borehole identification.

\subsubsection{Location}

Fracture locations are identified by position with respect to an arbitrary coordinate system which is oriented to be colncident with the borehole orientations. The zero azimuth of the arbitrary borehole coordinate system is $8^{\circ}$ west of north. The vertical elevation is also arbitrarily selected. Table A6 presents location data along with other interstitial properties of the fracture. It should be noted that the locations are not oriented with respect to true north. To convert from the local coordinate system described previously to a global coordinate system oriented on true north, the following transformation is applied:

$$
\left|\begin{array}{l}
\mathrm{x}_{\mathrm{g}} \\
\mathrm{y}_{\mathrm{g}}
\end{array}\right|=\left[\begin{array}{ll}
\mathrm{x} & \mathrm{y}
\end{array}\right]\left|\begin{array}{rr}
0.990 & 0.139 \\
-0.139 & 0.990
\end{array}\right|
$$

where

$\mathrm{x}, \mathrm{y}$ local cartesian coordinate system, $\mathrm{m}$; and

$\mathrm{x}_{\mathrm{g}}, \mathrm{y}_{\mathrm{g}} \quad$ global cartesian coordinate system, $\mathrm{m}$.

Table A6 presents fracture location and orientation data (described below) for mapped fractures. It is apparent from the table that fractures are located throughout the boreholes, with some intervals having more fractures.

\subsubsection{Density and Spacing}

Fracture density can be described in terms of elther one, two, and three dimensional measures. The one-dimensional measure consists of determining the number of fractures which intersect a line, such as a borehole, per unit length. A second measure consists of determining the number of fractures which intersect a plane, such as a mine shaft, quarry wall or ground surface, per unit area of the surface. A third measure consists of the number of fractures within a volume of extracted rock.

At the Apache Leap site, only the one dimensional measure is available from the borehole core logs. The observed density data are presented as Tables 6 and A7. From the Apache Leap site data it can be observed that fracture density variation is high, ranging from a density of no fractures per three meter interval to a maximum of 4.3 fractures per meter, which is noted at two locations. The distribution has the appearance of an exponential distribution, which is consistent with a Poisson process for fracture locations. Mean fracture spacing is the reciprocal of fracture density. 
Table 6: Summary of fracture density and orientation obtained from borehole cores at the Apache Leap Tuff Site.

\begin{tabular}{lccc}
\hline & & & \\
& FRACTURE & \multicolumn{2}{c}{ FRACTURE ORIENTATION } \\
DENSITY $(1 / \mathrm{m})$ & Strike $\left(^{\circ}\right)$ & Dip $\left(^{\circ}\right)$ \\
Mean & 0.77 & 214.4 & 64.5 \\
Coef. Var. & $108 \%$ & $56 \%$ & 378 \\
& & & \\
Minimum & 0.00 & 3. & 1. \\
Median & 0.67 & 109. & 55. \\
Maximum & 4.33 & 359. & 89. \\
\hline
\end{tabular}

\subsubsection{Orientation}

A downhole scribing tool was used to provide an orientation mark by etching the end of each core length prior to drilling. The $\mathrm{X}$-series boreholes were scribed on the top of the core while the $Y$ - and Z-series were scribed on the bottom. Mathematical, graphical and mechanical methods were used for correcting the apparent dips of fractures in the oriented drill cores taken from inclined boreholes (Weber, 1986). A graphical technique using a stereonet was used to verify the results. The procedure consists of assuming that the borehole lies in a vertical position when the observied angles are measured for a fracture plane intersecting the core. The borehole is then tilted into its inclined position and the resulting true dip and strike are calculated. The absolute orientation of fracture traces in the drill core are determined by measurement of two angles:

- The angle between the fracture plane and the core axis; and

- The angle between the major axis of the elliptical trace of the fracture plane and a line scribed on the drill core, measured on the circumference of the core.

The apparent angles of the fracture plane were measured in the laboratory using a goniometer, constructed after Goodman (1976). Zimmer (1963) provides a solution for converting the apparent angles to their true orientation, of the form:

$$
\begin{aligned}
S & =\operatorname{atan}((\cos \alpha \sin B+\tan \Gamma \cos B) / \sin \Gamma) \\
D & =\operatorname{acot}(\tan B / \sin (\operatorname{atan}(\cos \alpha \tan B+\tan \Gamma / \sin \alpha \tan B)) \\
& +\operatorname{acot}(\tan \Gamma / \sin (\operatorname{atan}(\cos \alpha \tan \Gamma+\tan B / \sin \alpha \tan \Gamma))
\end{aligned}
$$


where

B inclination of the borehole from the horizontal;

$\alpha$ azimuthal angle between the lower axis of the fracture plane ellipse and the scribe line;

$\Gamma$ vertical angle between the major axis of the fracture plane ellipse and the normal to the fracture plane;

S strike of fracture plane with respect to the borehole axis; and, D dip of fracture plane with respect to the horizontal plane;

Fracture orientation data are presented as Table A6 for all nine boreholes. The data indicate the presence of many north-south trending fractures which dip steeply to the west as well as a few randomly oriented fractures. This is not entirely consistent with surface fracture traces, which also indicate steeply dipping, east-west trending fractures. This additional fracture set is not manifested in the borehole cores either due to the positioning of the boreholes parallel to the fracture set, or due to the lack of such fractures in the immediate vicinity of the boreholes. 


\section{Hydraulic Characterization Parameters}

Hydraulic properties as reported here are divided into three elements; matrix, fracture and combined fracture-matric properties. Matrix properties are obtained from core segments, as described above, while combined fracture-matrix properties are derived from field testing procedures. The fracture properties are obtained by removing the effects of matrix properties from field data, and also by using laboratory tests to specifically evaluate fracture hydraulic characteristics.

The measured hydraulic properties of the rock matrix include the saturated hydraulic conductivity, moisture characteristic curve, and the unsaturated hydraulic conductivity curve. Field water content data are used to estimate field matric potentials using laboratory moisture characteristic curves. In addition to the rock matrix characteristics, field and laboratory data are used to characterize fracture hydraulic properties, as well as coupled fracture-matrix properties when they can not be differentiated.

\subsection{Matrix Hydraulic Properties}

Laboratory analysis of oriented borehole core segments are used to determine the hydraulic properties of the rock matrix. Because the rock segments were selected specifically excluding fractured intervals, the analyses are only appropriate for characterizing the rock matrix. Addressed in this section are the saturated flow properties, as well as the effect of variable saturation on the hydraulic properties.

\subsubsection{Saturated Hydraulic Conductivity}

The saturated hydraulic conductivity is a coefficient which relates the hydraulic head gradient to fluid flux according to Darcy's law:

$$
k_{3}=-q / 1
$$

where

$\mathrm{K}_{\mathrm{s}}$ hydraulic conductivity, $\mathrm{m} / \mathrm{s}$;

$\mathrm{q}$ fluid flux, $\mathrm{m} / \mathrm{s}$; and

$i$ hydraulic gradient, $\mathrm{m} / \mathrm{m}$.

The fluid flux is determined by dividing the volumetric flow rate, $Q\left(\mathrm{~m}^{3} / \mathrm{s}\right)$ as measured by a flow meter, by the cross sectional area, $A\left(\mathrm{~m}^{2}\right)$ :

$$
q=Q / A \text {. }
$$

For one-dimensional steady flow, the hydraulic gradient is determined by dividing the total head drop, $\Delta \mathrm{H}(\mathrm{m})$, across the sample by the length of the sample, $L(\mathrm{~m})$. The total head drop is calculated by noting that the total head is the sum of the pressure and elevation heads, or:

$$
i=\Delta H / L=\left[\left(p_{0}+z_{0}\right)-\left(p_{1}+z_{1}\right)\right] / L
$$


where

$p_{1}, p_{0}$ inflow and outflow pressure heads, respectively, $m$; and

$z_{1}, z_{0}$ inflow and outflow elevation heads, respectively, $m$.

The procedure employed to measure the saturated hydraulic conductivity from rock core segments uses the large segments in conjunction with a permeameter (Figure 6). The permeameter consists of an inflatable packer which is used to seal the annulus between the rock segment and an outer brass collar. Covers are placed over each end of the permeaneter and water is introduced under pressure at the upper surface of the rock segment. Outflow from the lower surface is collected and measured using a flow meter. Prior to performing the measurement, the rock core is saturated using sterile, $0.001 \mathrm{M} \mathrm{CaSO}_{4}$ solution as presented in Section 2.1 .

Tables 7 and $A 8$ present summaries and individual measurements of saturated hydraulic conductivity for each segment at all sample locations. The hydraulic conductivity values vary substantially, over three orders of magnitude, from 0.4 to over $400 \times 10^{-9} \mathrm{~m} / \mathrm{s}$, with a mean value of approximately $20 \times 10^{-9} \mathrm{~m} / \mathrm{s}$. The distribution of the values appears lognormal, with an extended tail toward higher values.

Table 7: Summary of saturated hydraulic conductivity values obtained from large core segments at the Apache Leap Tuff Site.

\section{LABORATORY SATURATED HYDRAULIC CONDUCTIVITY \\ $(\mathrm{E}-9 \mathrm{~m} / \mathrm{s}$ )}

$\begin{array}{lr}\text { Mean } & 21.31 \\ \text { Coef. Var. } & 3018 \\ \text { Minimum } & 0.69 \\ \text { Median } & 4.24 \\ \text { Maximum } & 438.28\end{array}$

\subsubsection{Moisture Characteristic Curve}

The moisture characteristic curve relates the water content or relative saturation of a rock sample to the matric suction of the water in the sample. The drainage portion of the moisture characteristic curve is obtained for the wet region (i.e., matric suctions less than $500 \mathrm{kPa}$ ) using the large segments in conjunction with a pressure extraction vessel, while the data for the dry region (i.e., matric suctions greater than $500 \mathrm{kPa}$ ) are obtained using the small segments in conjunction with a thermocouple psychrometer and a sample changer. 


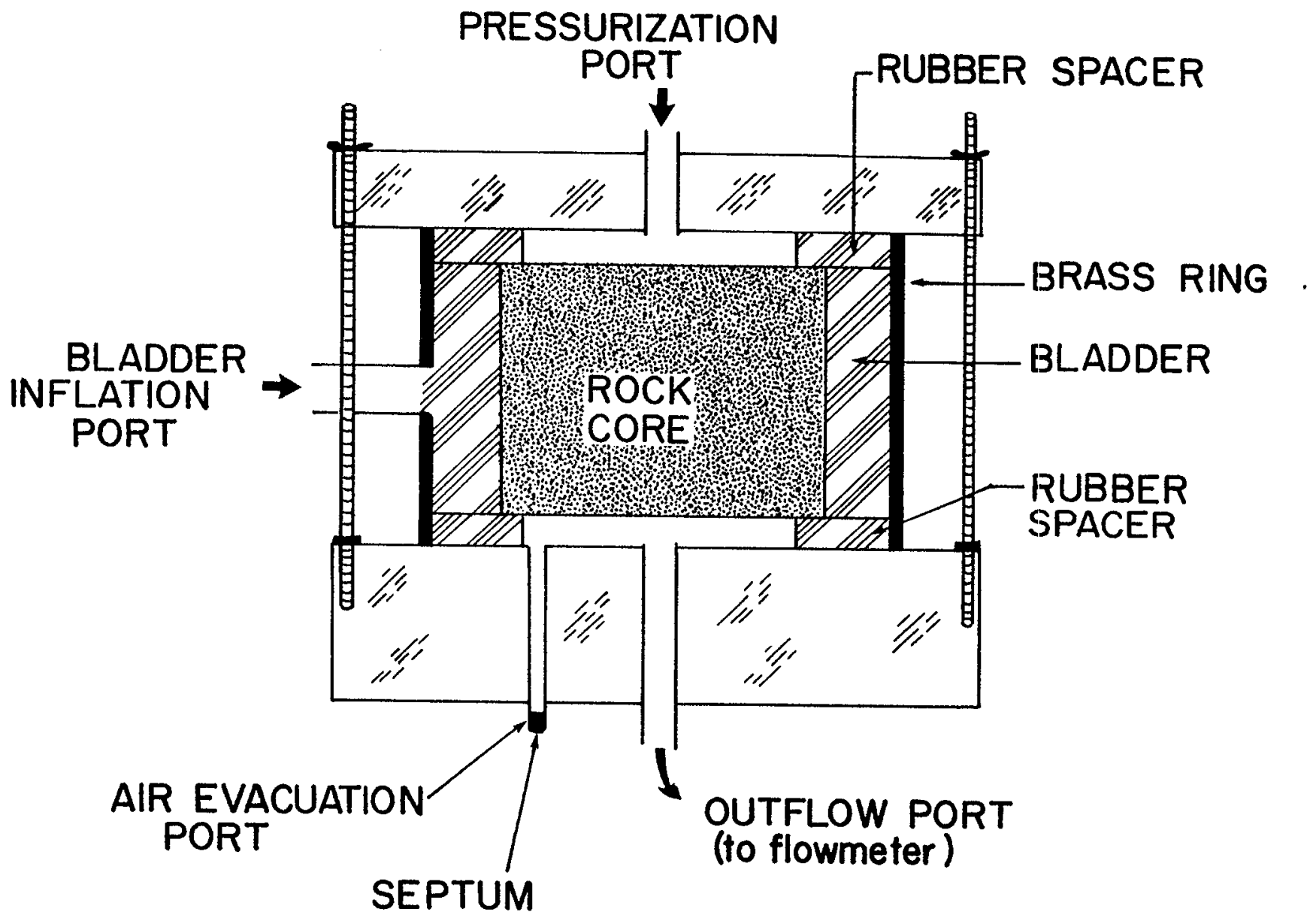

Figure 6: Permeameter used to obtain saturated hydraulic conductivity for large core segments. 
For matrix suctions less than or equal to $500 \mathrm{kPa}$, a pressure plate extractor is used to control the matric suction within a core segment. The procedure consists of saturating a large rock segment, placing the segment on a pressure plate (using a silica paste to establish a good hydraulic connection between the plate and the segment), sealing the pressure plate within the pressure vessel, and applying a desired matric suction using nitrogen gas to pressurize the vessel. Once the sample has reached equilibrium, the pressure is released, the vessel is opened, the sample is removed and the moisture content of the sample is determined gravimetrical1y. The sample is then returned to the pressure plate and a greater pressure is applied. Pressures of 10,25, 50, 100,300 and $500 \mathrm{kPa}$ were applied to the cores and corresponding sample water contents were determined.

For matrix suctions greater than $500 \mathrm{kPa}$, a thermocouple psychrometer is used in conjunction with a sample changer chamber. The procedure consists of saturating a small rock segment, placing the segment on a precision balance and drying until the desired relative saturation is achieved, transferring the segment to a chamber in the sample changer, and allowing the matric suction within the segment to equilibrate. Once the suction has stabilized within the chamber, the wet bulb depression of the atmosphere surrounding the rock segment is determined, along with the ambient temperature. From these two measurements the fluid potential within the chamber is determined. The sample is then dried to the next desired relative saturation. Relative saturations from 70 to 10 percent in 10 percent increments are used.

Tables 8 and A9 present summarles and complete data listings for pressure extractor, Tempe ce11, and thermocouple psychrometer results in tabular form. The data presented here indicate that the saturation of the matrix at a specified matric suction is highly variable, with increasing variation as the suction increases.

The characteristic curve data can be used to estimate the parameters of the Van Genuchten equation (Van Genuchten, 1978, 1980) of the form:

$$
S=\left(1+(\alpha \psi)^{n}\right)^{-m}
$$

where

$S$ relative saturation, dimensionless;

$\alpha$ scaling parameter, $\mathrm{kPa}^{-1}$;

$\psi$ matric suction, $\mathrm{kPa}$;

$\mathrm{n}$ fitting parameter, dimensionless; and

$m$ fitting parameter, dimensionless, equal to $1-1 / \mathrm{n}$.

Data from Tables $\mathrm{A} 9 \mathrm{a}$ and $\mathrm{A} 9 \mathrm{~b}$ were used to provide the least squared error estimate of relative saturation assuming a constant value of $n$ and $m$ for all samples, and no residual saturation. The procedure provided a minimum error for $n$ equal to 1.26 (m equal to 0.793 ). Table 8 presents the summary statistics for the estimated value of $\alpha$, while Table A9e provides the individual estimates of alpha. 
Table 8: Summary of laboratory moisture characteristic curve values obtained from pressure extraction vessel and Tempe Pressure Cells using large core segments and from thermocouple psychrometer data using small core segments at the Apache Leap Tuff Site. Mean wetting curves for 10 large core segments are also presented. Also shown are summary statistics for Van Genuchten moisture characteristic curve function.

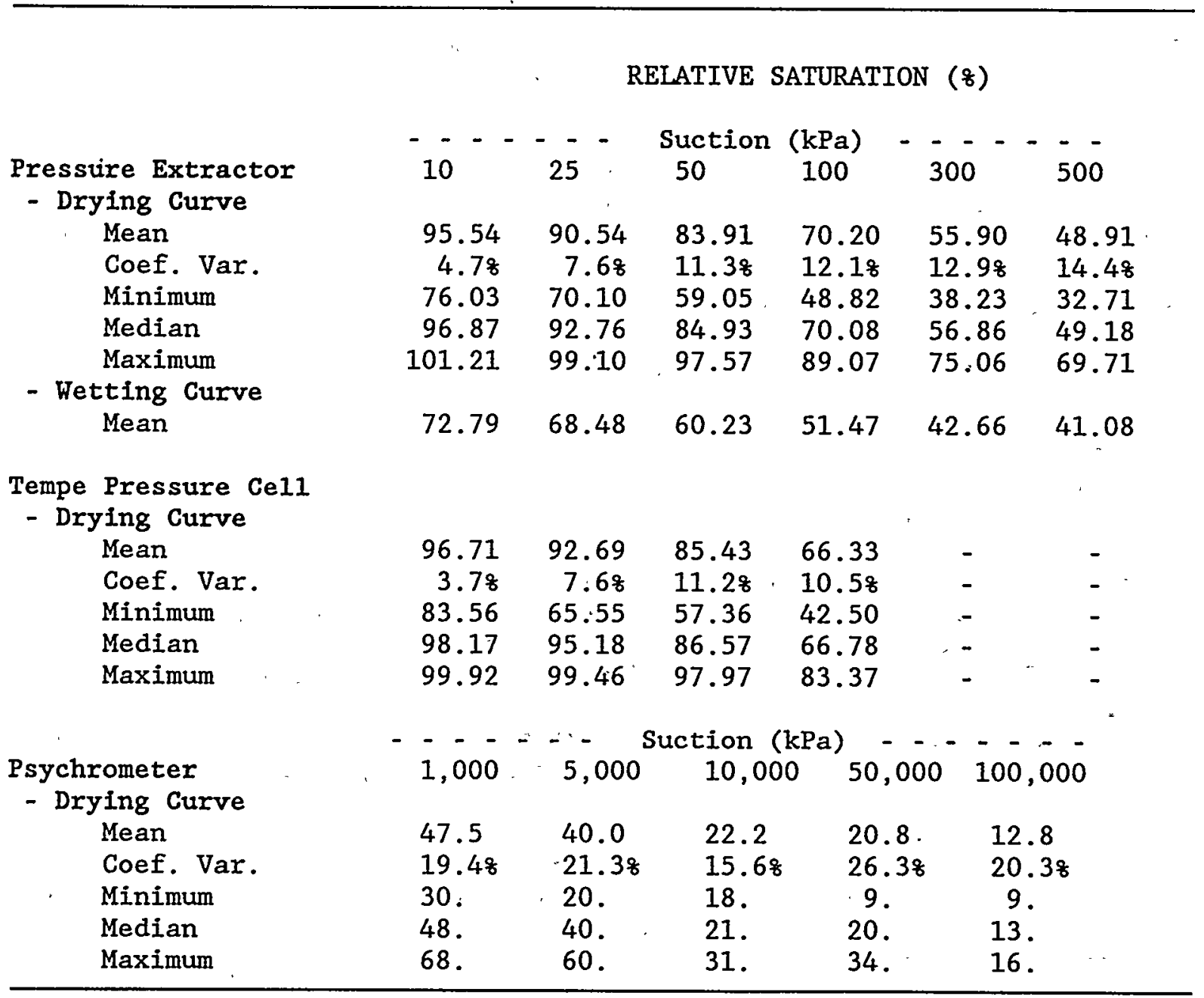

Van, Genuchten Moisture Characteristic Function $\left(\mathrm{n}=1.26, \Theta_{\mathrm{r}}=0.\right)$

$\alpha$-value

Mean

$\begin{array}{lr}\text { Coef. Var. } & 37.78 \\ \text { Minimum } & 0.0102\end{array}$

Median $\quad 0.0203$

Maximum $\quad 0.0643$ 


\subsubsection{Unsaturated Hydraulic Conductivity}

The hydraulic conductivity of a rock or soil sample is normally lower at higher matric suctions, or, equivalently at lower water contents. The outflow technique is used to determine the unsaturated hydraulic conductivity (Klute, 1964) of the 105 large core segments. The segments are saturated under a vacuum and then placed inside a Tempe pressure cell (Figure 7). A pressure increment is applied and the rate of outflow from the pressure cell is monitored using a small capacity pipette in conjunction with an air bubble which is injected through a septum at the upstream end of the pipette. A recirculation pump is occasionally used to remove accumulated air from the bottom of the porous plate. A burette is used to collect and measure the cumulative outflow from the plate. Klute (1964) presents an analytic solution for the outflow method when the hydraulic diffusivity is a constant over each pressure increment. For the samples and pressure increments employed in this analysis, however, the hydraulic diffusivity can not be assumed constant. Instead, an exponentially decreasing hydraulic conductivity is assumed over each pressure step:

$$
K\left(p_{1}\right)=K\left(p_{1}\right) \exp \left[a\left(p_{1}-p_{1}\right)\right]
$$

where

$\mathrm{K}$ hydraulic conductivity at pressure $\mathrm{p}, \mathrm{m} / \mathrm{s}$;

$\mathrm{p}_{\mathrm{f}}, \mathrm{p}_{\mathrm{l}}$ final and initial pressures, $\mathrm{Pa}$, respectively; and a regression coefficient, $1 / \mathrm{Pa}$.

Using the saturated hydraulic conductivity at zero pressure to begin the procedure, Equation (16) provides stepwise estimates of the unsaturated hydraulic conductivity. Lacking an analytic solution for the outflow method using this technique, a nonlinear least squares finite element program provided by Kool and Parker (1987) is modified to estimate the unsaturated hydraulic conductivity at each pressure step. Table 9 provides summaries for the unsaturated hydraulic conductivity data presented as Table A10.

Table 9: Summary of hydraulic conductivity values obtained from 105 large core segments at the Apache Leap Tuff Site.

$$
\begin{aligned}
& \text { HYDRAULIC CONDUCTIVITY (E-9 m/s) }
\end{aligned}
$$

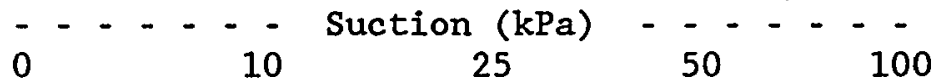

$\begin{array}{lrrrrr}\text { Mean } & 21.31 & 3.346 & 1.475 & 0.908 & 0.364 \\ \text { Coef. Var. } & 3018 & 1058 & 1568 & 115 \% & 112 \% \\ & & & & & \\ \text { Minimum } & 0.69 & 0.126 & 0.110 & 0.002 & 0.005 \\ \text { Median } & 4.24 & 2.610 & 0.556 & 0.498 & 0.235 \\ \text { Maximum } & 438.28 & 25.750 & 14.588 & 5.041 & 2.541\end{array}$


OUTFLOW METHOD EXPERIMENTAL SETUP

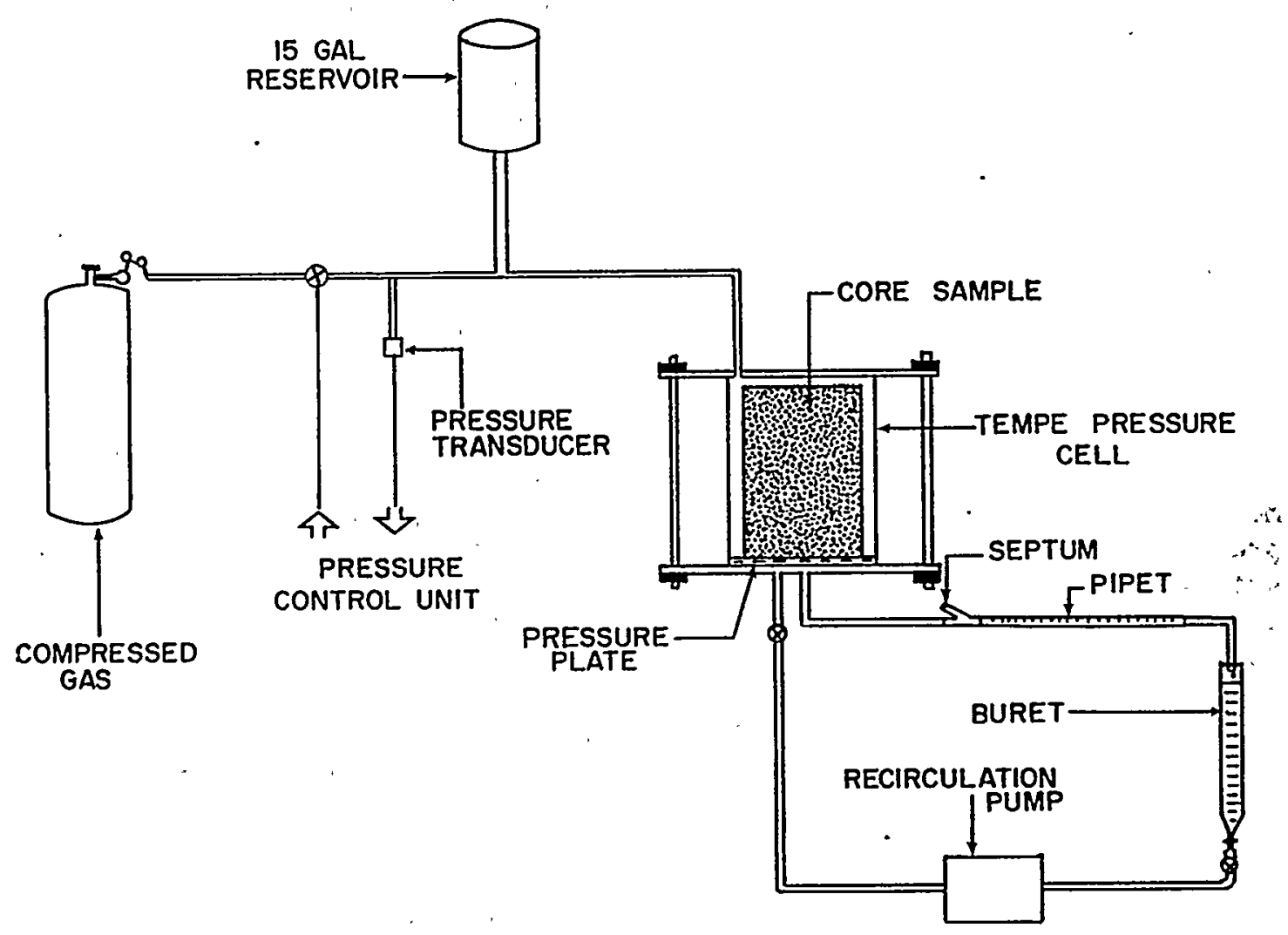

Figure 7: Laboratory apparatus for obtaining unsaturated hydraulic conductivity using the outflow method. 


\subsection{Field Hydraulic Properties}

Field tests of hydraulic conductivity and water content are important for comparison with laboratory data as well as for providing information about the ambient moisture regime at the site of interest. While field hydraulic tests cannot provide data about unsaturated hydraulic properties, they can be used to determine fracture hydraulic properties which are unavailable from core segments. Also, estimates of field water contents can be used to infer the ambient matric suction, and other unsaturated matrix properties.

\subsubsection{Field Hydraulic Conductivity}

Hydraulic tests in fractured rock with substantial matrix hydraulic conductivity are difficult to interpret due to the possibility for flow to occur in both the fractures and the matrix. The methodology described here assumes that an effective hydraulic conductivity exists which accounts for saturated liquid flow through both pathways. The equivalent saturated hydraulic conductivities of the fractures intersecting each three-meter borehole interval were determined using a modified falling-head borehole permeability test as described by Tidwell (1988) and Tidwell et al. (1988). The test yields the equivalent conductivity for both the matrix and the fractures.

The method for obtaining the equivalent conductivity involves maintaining a constant water level near the top of a borehole until a constant injection rate is established. A short packer with a tube through it and extending to the surface is lowered to a selected depth in the borehole. The tube extending to the surface is connected to one of three falling-head flow meters calibrated for different flow ranges. When the packer is inflated and the head above and below the packer are maintained equal, the meter measures the injection rate for the length of borehole below the packer. The packer is then lowered $3 \mathrm{~m}$ and a similar measurement is made. The difference in measured flow rates is the injection rate for the $3-\mathrm{m}$ borehole segment.

The injection rate is converted to equivalent hydraulic conductivity using three alternate mathematical solution. The first solution is a modification by Tidwell (1988) of the equation presented by Glover (1953) to incorporate inclined boreholes:

$$
K=[Q \operatorname{asinh}(L / r)-L / h] /\left[2 \pi\left(2 h L-2 L z-L^{2}\right) \sin B\right]
$$

where

$\mathrm{K}$ effective hydraulic conductivity, $\mathrm{m} / \mathrm{s}$;

$Q$ interval outflow rate, $\mathrm{m}^{3} / \mathrm{s}$;

$\mathrm{L}$ length of injection interval, $\mathrm{m}$;

$r$ borehole radius, $m$;

$h$ total borehole length, $m$;

$z$ distance from bottom of borehole to lower edge of tested interval, m.

B angle of borehole inclination. 
The second solution is a modification by Tidwell (1988) of the equation presented by Philip (1985) to again account for the sloping borehole and the packer contained flow:

$$
K=\left[h^{2} Q C_{0}\right] /\left[(3 / 2)^{2 / 3} r^{2} \pi \sin B\left(z^{\prime 2}-z^{2}\right)\right]
$$

where

$C_{0}$ geometric factor related to the eccentricity of the assumed prolate spheroid shape of the borehole (Philip, 1985); and

$z^{\prime}$ distance from bottom of borehole to upper edge of tested interval, m.

The third solution is a method presented by Dachler (1936):

$$
\mathrm{K}=\mathrm{Q} \ln (\mathrm{L} / \mathrm{r}) / 2 \pi \mathrm{L} \mathrm{h}_{\mathrm{w}}
$$

where $h_{w}$ is the mean pressure head in the injection interval. The calculated hydraulic conductivities of the boreholes using the three methods are presented in Tables 11 and $A 12$ as a summary and complete data sets, respectively. Like the matrix hydraulic conductivity data, the field data demonstrate a high variability, ranging over five orders of magnitude. The data indicate a high degree of skewness toward the higher values, with two intervals in particular accounting for extreme rates of flow.

Table 10: Summary of field determined outflow rates and saturated hydraulic conductivity values at the Apache Leap Tuff Site.

\subsubsection{Field Water Content}

Matric suction is difficult to assess in a consolidated rock because the suction is disturbed by the process of measurement. At present, the matric suction is inferred from the field measured water content and the laboratory derived characteristic curves. The inferred value indicates the 
general water status but may not be sufficient to reliably estimate hydraulic head gradients.

The determination of field water content is possible using a neutron source and detector (Blanford and Rasmussen, 1988). The measurement of thermalized neutron flux makes possible the long term monitoring of water content changes within the rock at the ALTS. Prior to estimating the water content, however, a calibration curve must be developed to relate observed neutron counts with field water contents. The following sections describe calibration activities, along with observed water content changes using the developed calibration equation.

Changes in rock water content using neutron logging have been measured within the nine inclined boreholes at the ALTS. In addition, investigations of heat flow in welded tuff by Davies (1987) using heaters placed in $5.1 \mathrm{~cm}$ diameter boreholes have shown long term changes in rock water content. In order to quantify these changes a theoretical calibration curve has been developed by Elder (thesis in preparation). While the calibration curve has been validated for soils, negative water contents occasionally result when using the calibration for welded tuff near the Apache Leap Test Site. Because negative water contents are impossible and also because accurate estimates of rock water contents are important, a calibration curve derived from field data was deemed necessary. The observed calibration curve is also necessary to adjust the theoretical calibration curve for differences in geometric factors, such as borehole diameter, and for differences in rock bulk densities.

Calibration of rock water content with neutron counts is difficult due to the difficulties associated with extracting rock samples. Existing augering and drilling methods are inappropriate for correlating field estimates of thermalization properties to water content due to the large thermal and hydraulic disturbances induced using these methods. Alternately, rock chips can be placed in large drums and the thermalization properties determined for various water contents. Substantial differences in bulk density will occur, however, due to the difficulty in repacking the rock chips to the original bulk density.

To obtain a relationship between neutron counts and water content at the ALTS, two neutron calibration holes were excavated to a depth of $1.8 \mathrm{~m}$ using a pneumatic hammer. The calibration holes have a diameter of $5.1 \mathrm{~cm}$ and were located so that one hole was more likely to have a higher water content than the other. The wetter hole was located in the middle of an ephemeral stream channel, while the drier hole was located away from water sources other than precipitation. The locations of the neutron calibration boreholes are indicated in Figure 8. Each hole was capped with a stopper to prevent evaporation or saturation due to unexpected precipitation or surface flows. Both holes were then allowed to equilibrate for 21 and 32 days, respectively, to allow any effects of excavation to dissipate. Neutron counts at various depths in the calibration holes after equilibration are presented in Table 11. 


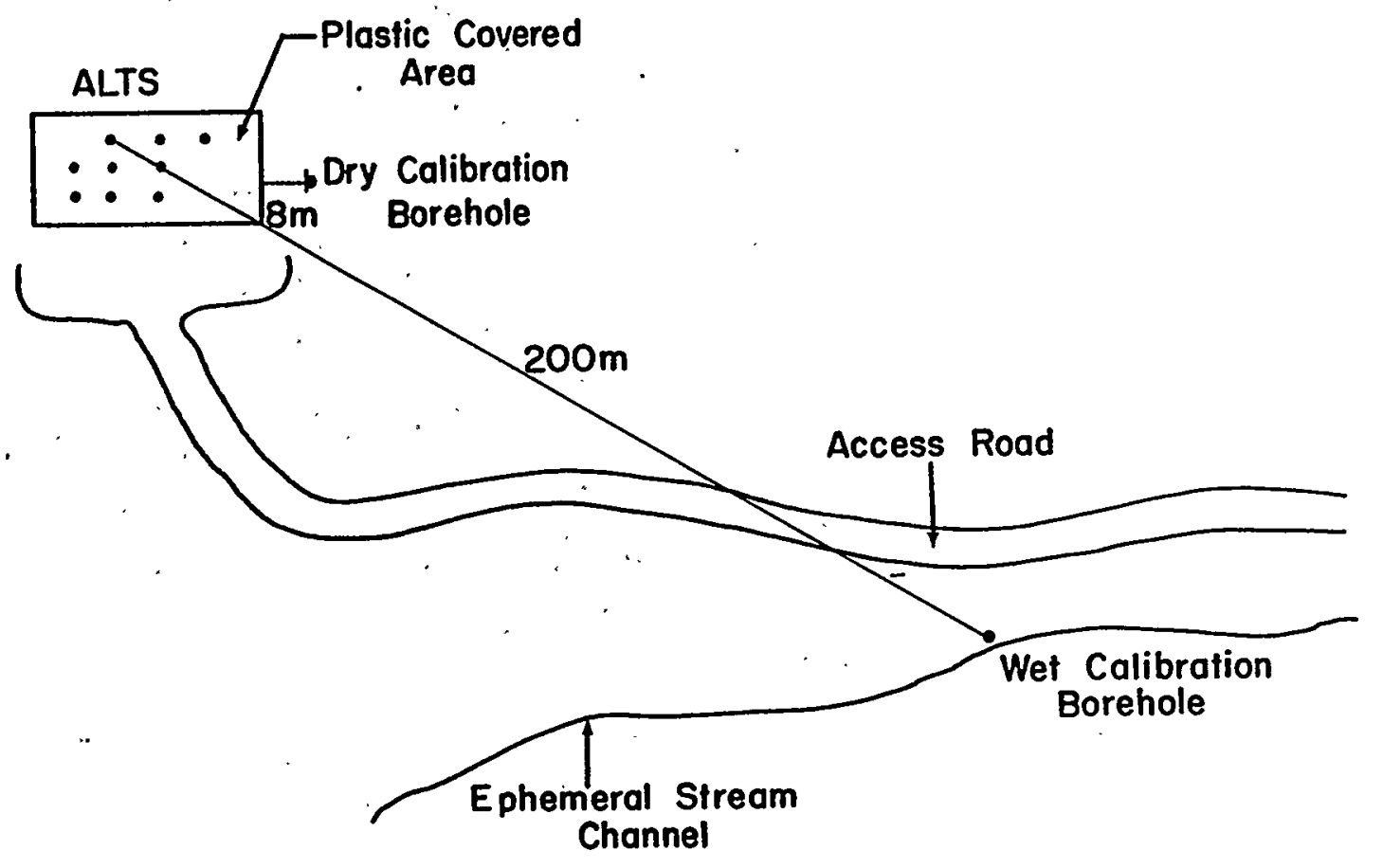

Figure 8: Location of neutron water content calibration boreholes. 
Table 11: Observed neutron counts with depth at two calibration boreholes, Apache Leap Tuff site. Counts in the dry and wet boreholes were obtained on $10 / 24$ and $11 / 4 / 87$, respectively.

\begin{tabular}{ccc} 
Depth & Dry Borehole Wet Borehole \\
(m) & -- - (Counts $/ 120$ s) - - - \\
& \multicolumn{3}{c}{} \\
0.30 & 63,984 & 81,667 \\
0.40 & 64,252 & 83,370 \\
0.50 & 64,437 & 82,722 \\
0.60 & 64,417 & 80,722 \\
0.85 & 65,360 & 84,276 \\
1.10 & 65,263 & 83,639 \\
1.35 & 65,902 & 79,590 \\
1.60 & 69,567 & 81,417
\end{tabular}

After the equilibration period, a pneumatic hammer was used to remove rock samples from the surface down to a depth of $0.42 \mathrm{~m}$ in the dry hole and 0.50 $m$ in the wet hole. Upon excavation, the rock samples vere immediately placed inside a collection can and weighed. Approximately twenty rock samples were removed from around each calibration hole. Each sample weighed approximately $0.150 \mathrm{~kg}$. The samples were taken to the laboratory where they were oven-dried and reweighed to determine the field water content. To determine the relative saturation, porosity, and volumetric water content the samples were saturated under a vacuum and reweighed while suspended under water. Table 12 presents the results of the analyses for rock samples extracted from the two neutron calibration boreholes.

Table 12: Results for neutron calibration borehole tests, Apache Leap Tuff Site. Neutron measurements were obtained at a depth of $0.40 \mathrm{~m}$.

$\begin{array}{lcc} & \text { 'Dry' Borehole } & \text { 'Wet' Borehole } \\ \text { Neutron Counts per } 120 \mathrm{~s} & 64,239 \pm 80 & 82,547 \pm 64 \\ \text { Bulk Density }\left(\mathrm{Mg} / \mathrm{m}^{3}\right) & 2.13 & 2.09 \\ & & \\ \text { Water Content } & 10.2 \% & 14.2 \% \\ \text { Observed } & 5.8 \% & 10.3 \% \\ \text { Predicted } & \end{array}$


The predicted water content in Table 12 was obtained using a nonlinear theoretical model developed by Elder (1988). A linearized approximation to the weakly nonlinear model is:

$$
\theta=4.938 \mathrm{E}-6 \mathrm{C}-0.1008
$$

where $\theta$ is the water content, dimensionless, and $C$ is the number of neutron counts per minute for a 5-cm diameter borehole. A linear relationship between water content and neutron counts based upon the calibrated data is:

$$
\theta=4.380 \mathrm{E}-6 \mathrm{C}-0.0387
$$

It can be observed from the two equations that the slopes of the linear relationships are reasonably similar (within 12 percent of each other) which is because the number of neutron counts is directly related to the change in the amount of water present, and is not expected to vary significantly between theory and field data. The intercepts, however, are substantially different (varying by 260 percent) due to the failure of model parameters to predict the effect of the rock mass on the thermalization of neutrons. The diffusion of neutrons through a rock mass of high density is probably not described by a theory which was developed for applications involving neutron diffusion through the lower bulk density of unconsolidated soil particles.

Additional calibration of neutron counts at various water contents within 5 and $10 \mathrm{~cm}$ diameter boreholes will be performed to further validate the calibration curve. A third hole in a dryer location will be drilled, monitored and excavated to validate the present empirical calibration curve and to verify the linearity of the curve over the full. range of water contents expected at the AITS.

The X-series, of boreholes were the first to be drilled, in September of 1985. The Y- and Z-series were drilled in November of 1986 . Seven sheets of $30 \mathrm{mil}$ high density polyethylene were emplaced in January 1987 and welded together in April of that year to form a $30 \times 50 \mathrm{~m}$ barrier to infiltration into the rock surrounding the boreholes. A concrete berm was placed along the margin of the plastic to prevent water from seeping in along the sides. Neutron logging of the boreholes at approximately $3-\mathrm{m}$ intervals was begun on February 10, 1987 and continues at roughly 50 day intervals. The initial water contents may have been affected by drilling of the boreholes, which was performed using liquid recirculation.

Hydraulic testing of the boreholes occurred intermittently between March and July of 1987. The testing was conducted on all nine boreholes and consisted of flooding each borehole individually. In August and September Boreholes $\mathrm{X} 1, \mathrm{Y} 1, \mathrm{X} 2$ and $\mathrm{Y} 2$ were filled immediately with water and maintained at nearly constant water levels throughout the experiment. In Boreholes X2 and $\mathrm{Y} 2$, a head of 0.5 meters above the upper end of the casings was maintained by using a siphon, while boreholes $\mathrm{Xl}$ and $\mathrm{Yl}$ were allowed to fluctuate between 1 and $4 \mathrm{~m}$ below the top of the casing from .time $=0$ to 415 hours. The mean head during this period was approximately 
$2 \mathrm{~m}$ below the casing. After 415 hours, a constant head of $0.5 \mathrm{~m}$ above the casing was applied to the two boreholes. When the head was maintained constant at $0.5 \mathrm{~m}$ of head, the outflow was measured while maintaining a nearly constant head.

Until 415 hours, the water levels in boreholes $\mathrm{X} 1$ and $\mathrm{Y} 1$ were allowed to drop and the elapsed time and volume of water required to refill the holes was used to calculate outflow. At times, small bubbles accumulated in the siphons causing a slight head drop and lessening of flow rate. At various times the siphons were re-established, as indicated by the data. At the end of the test interval, the boreholes were drained. The volume of water required to fill and drain the boreholes was not recorded, but the water removed at the end to the test is estimated to be approximately equal to the borehole volumes for $\mathrm{XI}$ and $\mathrm{Y} 1$, and equal to about 1.5 times the borehole volumes for $\mathrm{X} 2$ and $\mathrm{Y} 2$. Reported outflow data are precise to two significant digits.

Boreholes X1, X2, and $\mathrm{Y} 1$ were flooded for twenty days while Borehole Y2 was flooded for an additional three days. Table A12 presents the observed outflow rates for the four boreholes. Tables 13 and A13 present summary and individual water content data, respectively, for the nine boreholes for dates ranging from February 10, 1987 (Julian day 41 from 1/1/87) through May 19, 1988 (Julian day 505 from 1/1/87). Continuous flooding of Boreholes X1, Y1, X2 and Y2 occurred between days 236 and 255 .

Table 13: Field water contents for various dates at the Apache Leap Tuff Site.

\begin{tabular}{|c|c|c|c|c|c|c|c|c|}
\hline & $-{ }_{41}^{-}-$ & $-{ }^{\mathrm{BO}}$ & $\begin{array}{l}\text { REHOLE W } \\
\text { Julian } \\
255\end{array}$ & $\begin{array}{l}\text { WATER } \\
\text { n Date } \\
279\end{array}$ & $\begin{array}{l}\text { CONTENTS } \\
\text { From } 1 / \\
372\end{array}$ & $\begin{array}{c}\left(\mathrm{m}^{3} / \mathrm{m}^{3}\right) \\
1 / 87 \\
406\end{array}$ & $-{ }^{-}-$ & --- \\
\hline $\begin{array}{l}\text { Mean } \\
\text { Coef. Var. }\end{array}$ & $\begin{array}{r}13.75 \\
118\end{array}$ & $\begin{array}{r}14.12 \\
118\end{array}$ & $\begin{array}{r}14.59 \\
128\end{array}$ & $\begin{array}{r}14.50 \\
128\end{array}$ & $\begin{array}{r}14.36 \\
128\end{array}$ & $\begin{array}{r}14.32 \\
128\end{array}$ & $\begin{array}{r}14.32 \\
128\end{array}$ & $\begin{array}{r}14.26 \\
12 \%\end{array}$ \\
\hline $\begin{array}{l}\text { Minimum } \\
\text { Median } \\
\text { Maximum }\end{array}$ & $\begin{array}{l}10.19 \\
13.71 \\
17.63\end{array}$ & $\begin{array}{l}10.85 \\
14.04 \\
17.29\end{array}$ & $\begin{array}{l}10.89 \\
14.46 \\
18.75\end{array}$ & $\begin{array}{l}10.77 \\
14.48 \\
18.42\end{array}$ & $\begin{array}{r}9.99 \\
14.33 \\
17.74\end{array}$ & $\begin{array}{r}9.53 \\
14.35 \\
17.77\end{array}$ & $\begin{array}{r}9.85 \\
14.18 \\
17.57\end{array}$ & $\begin{array}{l}10.14 \\
14.23 \\
17.51\end{array}$ \\
\hline
\end{tabular}




\section{Pneumatic Characterization Parameters}

Air flow through the unsaturated zone can result from pressure and density gradients induced by atmospheric driving forces or subsurface heat generation. The induced air flow can affect subsurface moisture contents and, hence liquid redistribution, by transporting water vapor through air filled porosity. Also, equilibrium of matric potentials between isolated liquid phases can be attained as a result of water transport as vapor. To evaluate rates and pathways for air flow in the unsaturated zone, methods for estimating the moisture dependent pneumatic permeability of the rock matrix and fracture system are addressed in this section.

\subsection{Matrix Pneumatic Permeability}

The pneumatic permeability for both oven-dried and partially saturated large rock core segments is obtained by employing the permeameter previously described in Section 3.1.1 and illustrated in Figure 6. A core segment is brought to a desired potential by either, drying the segment in a drying oven or by allowing the sample to equilibrate within a pressure extraction vessel, as described in Section 3.1.2. Once a prescribed suction is achieved, the core sample is placed inside the permeameter with the packer inflated to prevent bypassing of air around the outside of the core. A known pressure gradient is applied longitudinally across the core segment and the air flow volume is measured using a calibrated flow meter. The pneumatic permeability at each suction is determined using the measured air flow rate, cross sectional area and core segment length. Because air is compressible, the ideal gas law is employed with the assumption of isothermal flow:

$$
k_{\mathrm{a}}=2 \mathrm{QL} \mathrm{H} \mathrm{H}_{\mathrm{O}} \mu / \gamma \mathrm{A}\left(\mathrm{H}^{2}-\mathrm{H}_{\mathrm{o}}^{2}\right)
$$

where

$k_{\mathrm{a}}$ pneumatic permeability, $\mathrm{m}^{2} ;$
$\mathrm{Q}$ measured flow rate, $\mathrm{m}^{3} / \mathrm{s} ;$
$\mathrm{L}$ core length, m;
$\mathrm{H}_{0}$ outflow pressure head, $\mathrm{m} ;$
$\mu$ viscosity of air, $\mathrm{Pa} \mathrm{s} ;$
$\mathrm{A}$ core cross sectional area, $\mathrm{m}^{2} ;$
$\gamma \quad$ specific weight of water, $\mathrm{Pa} / \mathrm{m} ;$ and
$\mathrm{H}$ inflow pressure head, $\mathrm{m}$.

Table 14 summarizes the test results and demonstrate the large variability between samples, while Table A14 presents the test results for individual segments. The variability is highly skewed, as evidenced by the discrepancy between the mean and median values for all applied suctions.

The measured air permeability of an oven-dried sample is usually similar to the measured water permeability. However, for the tuff cores, the estimates may not be similar due to slip flow along the walls of pores (Klinkenberg, 1941). The importance of the Klinkenberg phenomenon, as 
Table 14: Summary of laboratory air permeabilities $\left(\mathrm{m}^{2} \mathrm{E}-16\right)$.

\begin{tabular}{|c|c|c|c|c|c|c|c|}
\hline & $\overline{10}$ & ---- & $\begin{array}{c}\text { Suctio } \\
50\end{array}$ & $\begin{array}{c}(\mathrm{kPa}) \\
100\end{array}$ & --- & $--\overline{500}$ & $\begin{array}{l}\text { Oven } \\
\text { Dried }\end{array}$ \\
\hline $\begin{array}{l}\text { Mean } \\
\text { Coef. Var. }\end{array}$ & $\begin{array}{l}1.54 \\
4348\end{array}$ & $\begin{array}{r}11.20 \\
4368\end{array}$ & $\begin{array}{r}16.88 \\
3448\end{array}$ & $\begin{array}{r}26.67 \\
3268\end{array}$ & $\begin{array}{r}35.11 \\
3098\end{array}$ & $\begin{array}{r}38.23 \\
2958\end{array}$ & $\begin{array}{l}57.12 \\
272 \%\end{array}$ \\
\hline $\begin{array}{l}\text { Minimum } \\
\text { Median } \\
\text { Maximum }\end{array}$ & $\begin{array}{r}<0.01 \\
0.05 \\
41.90\end{array}$ & $\begin{array}{r}<0.01 \\
0.10 \\
333.10\end{array}$ & $\begin{array}{r}0.02 \\
0.39 \\
389.80\end{array}$ & $\begin{array}{r}0.25 \\
2.10 \\
678.70\end{array}$ & $\begin{array}{r}1.29 \\
5.09 \\
780.50\end{array}$ & $\begin{array}{r}1.91 \\
6.04 \\
780.50\end{array}$ & $\begin{array}{r}3.81 \\
12.08 \\
1012.60\end{array}$ \\
\hline
\end{tabular}

it is commonly called, can be evaluated by comparing the computed air permeability for oven-dried cores with the computed water permeability for completely saturated cores. The two values should be a function of the ambient air pressure used to conduct the air permeability test, as well as the mean free path of the gas molecules and the pore diameter (Klinkenberg, 1941):

$$
k_{a}=k_{w}\left(1+b / p^{*}\right)=k_{w}(1+8 C \lambda / d)
$$

where

b Klinkenberg slip-flow coefficient, $\mathrm{Pa}$;

$\mathrm{p}^{*}$ mean air pressure on the sample, $\mathrm{Pa}$;

C proportionality factor, approximately equal to one;

$\lambda$ mean free path at pressure $\mathrm{p}^{*}, \mathrm{~m}$; and

d pore diameter, $m$.

The Klinkenberg slip-flow coefficient is important because the Knudsen diffusion coefficient, $D_{k}\left(m^{2}\right)$, can be derived from it using $D_{k}=k_{w} b / \mu$ (Thorstenson and Pollock, 1989), where $\mu$ is the gas viscosity ( $\mathrm{Pa} S$ ).

Data in Tables A8 (laboratory saturated hydraulic conductivity) and A14 (laboratory oven-dried pneumatic permeability) are used to calculate the Klinkenberg coefficient and equivalent pore sizes of oven-dried cores for nitrogen gas at mean air pressures of $108 \mathrm{kPa}$ and an assumed mean free path of $9 \times 10^{-8} \mathrm{~m}$. Table 15 presents summaries of the observed values, while Table A15 presents the data for all samples. 
Table 15: Summary of laboratory determined Klinkenberg slip flow coefficient.

\section{KLINKENBERG COEFFICIENT}

$(\mathrm{kPa})$

Mean

322.1

Coef. Var.

82 \%

Minimum

35.

Median

217.

Maximum

1277.

\subsection{Field Pneumatic Properties}

Field estimates of pneumatic permeabilities are obtained using single hole air injection tests over three meter intervals corresponding to sample locations coincident with laboratory core segment tests and field hydraulic tests. The field test procedure consists of locating two inflatable packers at either end of a test interval, inflating the packers to isolate the test interval, injecting a controlled mass flow rate of air into the interval, and measuring the absolute pressure in the injection interval. The air permeability is calculated using an equation developed by Dachler (1936) and subsequently adapted for compressible air flow (Figure 9). The analytic equation is of the form:

$$
\mathrm{k}_{\mathrm{a}}=\mathrm{Q} \mu \mathrm{P}_{0} \ln \left(\mathrm{L} / \mathrm{I}_{\mathrm{w}}\right) / \gamma \mathrm{L}\left(\mathrm{P}_{2}{ }^{2}-\mathrm{p}_{1}{ }^{2}\right)
$$

where

$k_{2}$ pneumatic permeability, $\mathrm{m}^{2}$;

$Q$ volumetric flow rate at standard temperature and pressure, $\mathrm{m}^{3} / \mathrm{s}$;

$\mu$ dynamic viscosity of air, $\mathrm{Pa} \mathrm{s}$;

$P_{0} \quad$ standard pressure, $\mathrm{Pa}$;

I borehole interval length, $\mathrm{m}$;

$r_{w}$ borehole radius, $m$;

$\mathrm{P}_{2}$ pressure in injection interval, $\mathrm{Pa}$; and

$P_{1}$ atmospheric pressure, $86.0 \mathrm{kPa}$.

The analytic solution assumes that the test medium is homogeneous in the vicinity of the test interval, and that no leakage around the packers occurs. Also, the assumption is made that no air leakage through the rock into the borehole above or below the packers is occurring. Flow rate is in standard cubic meters per second, which has been adjusted from a mass flow rate using standard temperature and pressure. Table 16 summarizes results 
of the single hole tests, and Table A16 present data for all tested intervals.

Of interest is the greater air permeability in the laboratory when compared to the water permeability. As described in the previous section this difference can be attributed to the Klinkenberg effect. Of more serious concern, however, is the observation that the field estimated air permeability is lower than the field estimated water permeability. This difference can most likely be attributed to the presence of water in the rock, which is not the case for an oven-dried sample.

Table 16: Summary of field determined air permeability. One interval exceeded capacity of measurement device, while a second interval was less than the measurement threshold.

\begin{tabular}{lc} 
FIELD AIR PERMEABILITY \\
\multicolumn{2}{c}{$\left(\mathrm{m}^{2} \mathrm{E}-16\right)$} \\
Mean & 178.1 \\
Coef. Var. & 6678 \\
Minimum & $<0.420$ \\
Median & 4.02 \\
Maximum & $>13,366$ \\
\hline
\end{tabular}




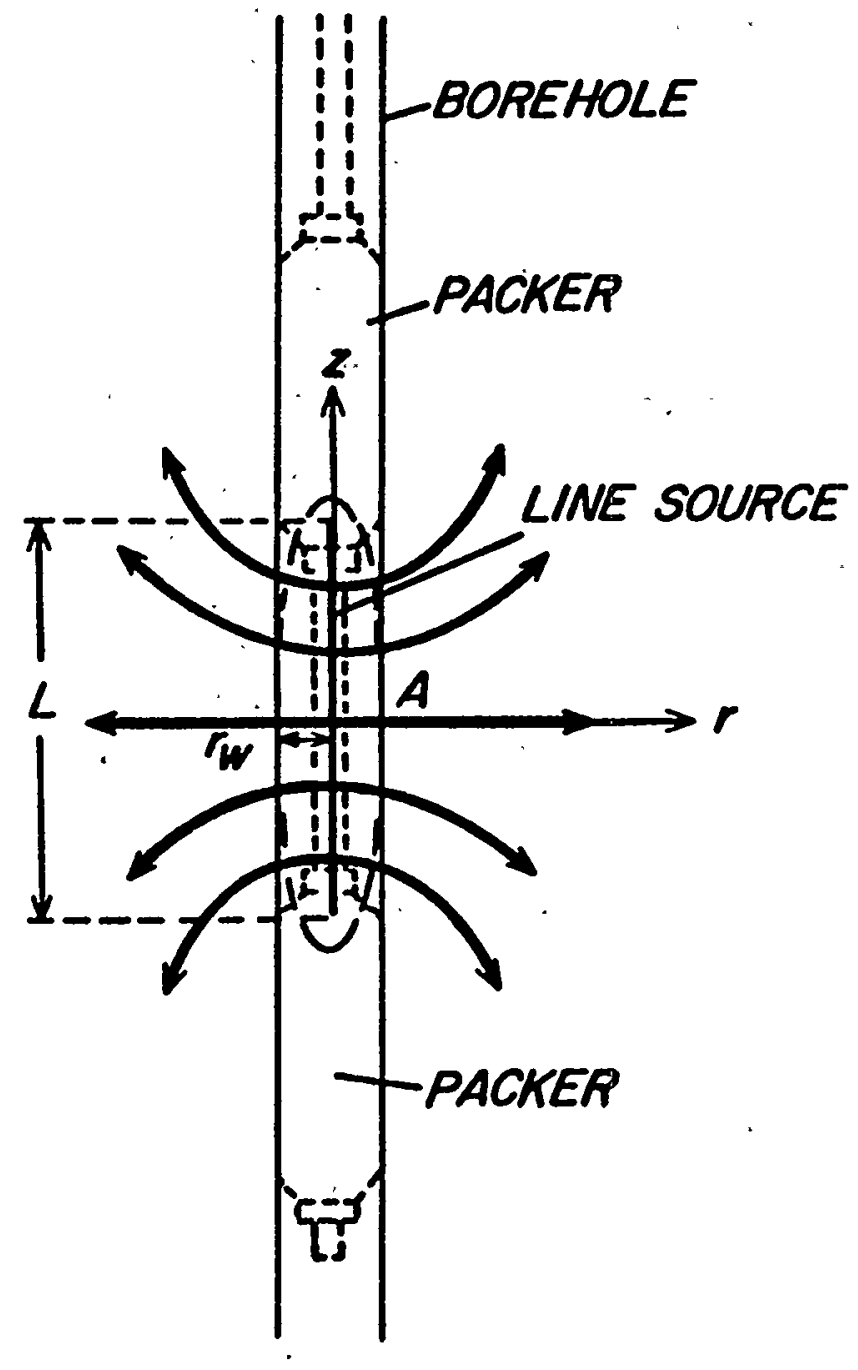

Figure 9: Diagram of field single hole air injection experiment. 


\section{Therma1 Characterization Parameters}

Thermal gradients can substantially affect the movement of water as liquid and vapor in the subsurface (Tsang and Pruess, 1987). Characterization of thermal sources and sinks, as well as the moisture dependent thermal properties of the rock matrix and fractures, is important for modeling thermal effects on fluid and solute transport. This section presents laboratory and field data sets for thermal parameters corresponding to sample locations consistent with other data sets presented in this report.

\subsection{Matrix Thermal Properties}

Thermal properties of the rock matrix are estimated by drilling two holes in the large core segments (Figure 10). The holes are $0.36 \mathrm{~cm}$ in diameter, one hole lying along the radial axis of the core segment extending into the rock $4.5 \mathrm{~cm}$. The second hole lies approximately $0.7 \mathrm{~cm}$ from the central hole and extends $2.5 \mathrm{~cm}$ into the core. At desired water contents, liquid mercury at room temperature is added to each hole until the level of mercury is slightly below the core surface. A heating unit composed of precision resistance wire wrapped around a copper wire core is placed in the central hole. A thermistor probe is placed near the bottom of the outer hole. The rock is then placed within an insulating plexiglas chamber which fits snugly around the core. The entire apparatus is then placed within a constant temperature chamber. A known electric current is used to heat the unit in the central hole for approximately 150 seconds. A response to the heating event is observed in the outer hole, the magnitude of which is used to evaluate the thermal conductivity of the sample for each water content.

The thermal conductivity is found by using a radial flow equation:

$$
\Delta \mathrm{T}=\mathrm{Q} / 4 \mathrm{~K}_{\mathrm{t}} \mathrm{W}(\mathrm{u})
$$

where

$\Delta \mathrm{T}$ temperature change from initial conditions, ${ }^{\circ} \mathrm{C}$;

$Q$ heat $f l u x$ per unit thickness, $W / m$;

$\mathrm{K}_{\mathrm{t}}$ thermal conductivity, $\mathrm{J} / \mathrm{ms}^{\circ} \mathrm{C}$; and

$W(u)$ exponential integral, defined here as:

$$
W(u)=\int_{u}^{\infty}\left[e^{-x} / x\right] d x
$$

and

$$
u=r^{2} c / 4 k_{t} t
$$

where

$r$ distance between the center and observation hole, $m$;

$\mathrm{C}$ heat capacity, $\mathrm{J} / \mathrm{m}^{3 \circ} \mathrm{C}$; and

$t$ time, $s$. 


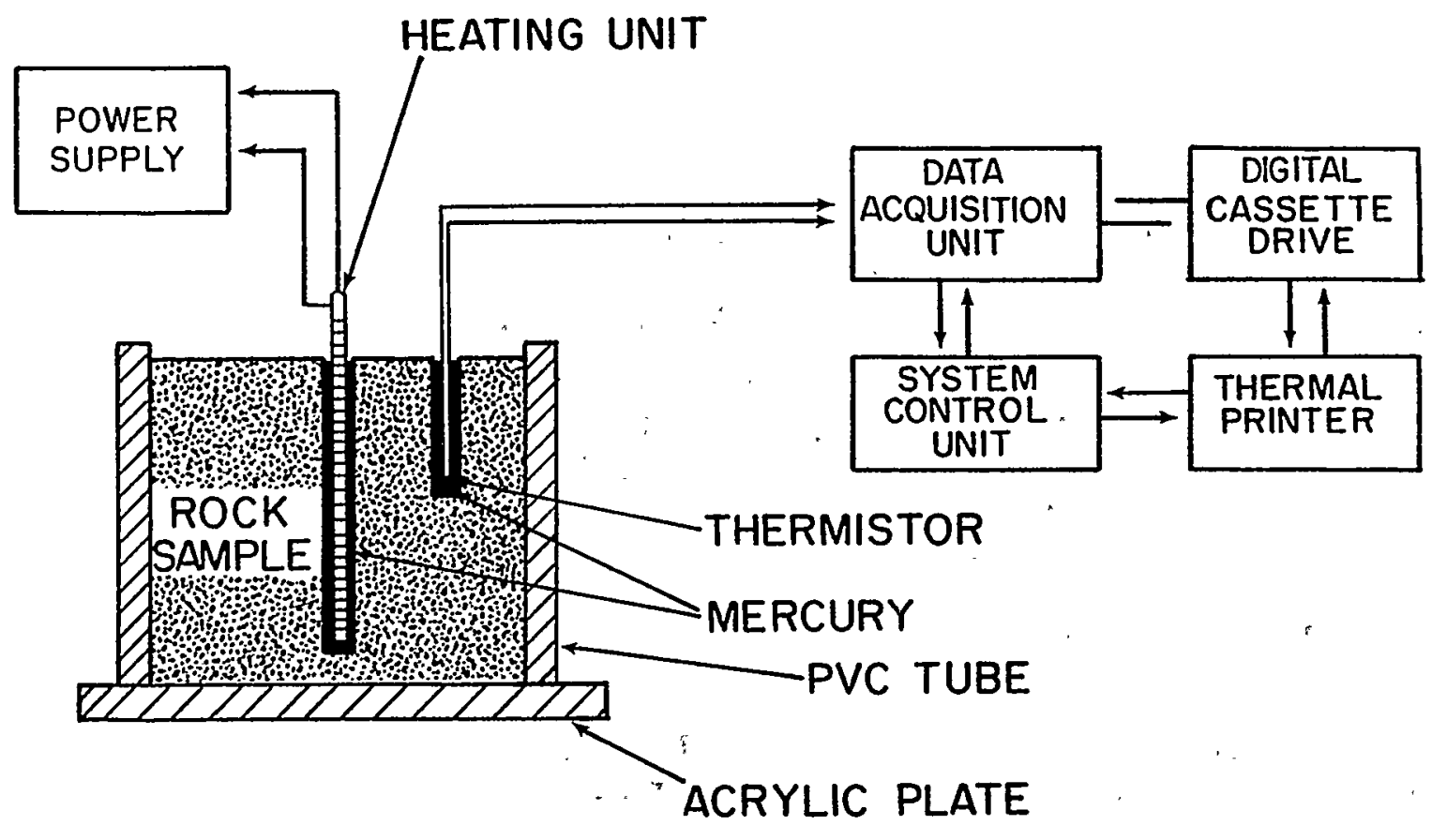

Figure 10: Apparatus used to estimate water content dependent thermal properties. 
Inversion of Equations (26) and (27) to obtain estimates of $K_{t}$ and $C$ is obtained using an iterative procedure suggested by Grimestad (1981):

$$
\left(C / K_{t}\right)_{n+1}=\left(C / K_{t}\right)_{n}\left(1+\ln \left(T_{1} W_{2} / T_{2} W_{1}\right) /\left(\exp \left[-u_{2}\right] / W_{2}-\exp \left[-u_{1}\right] / W_{1}\right)\right)
$$

where

$\mathrm{n}$ iteration number;

$\mathrm{T}_{1}, \mathrm{~T}_{2}$ observed temperatures at successive times, ${ }^{\circ} \mathrm{C}$;

$u_{1}, u_{2}$ values of $u$ at successive times; and

$W_{1}, W_{2}$ values of $W(u)$ at successive times.

Once the value of $c / K_{t}$ has stabilized, the value of $c$ and $K_{t}$ can be determined using:

$$
\mathrm{K}_{\mathrm{t}}=\mathrm{q} \mathrm{W}_{1} / 4 \mathrm{~T}_{1}=\mathrm{q} \mathrm{W}_{2} / 4 \mathrm{~T}_{2}
$$

and

$$
\mathrm{C}=\mathrm{K}_{\mathrm{t}}\left(\mathrm{C} / \mathrm{K}_{\mathrm{t}}\right)_{\mathrm{n}+1}
$$

A check of $\mathrm{C}$ can be made by noting that:

$$
\mathrm{C}=\mathrm{C}_{w} \theta \rho_{\mathrm{w}}+\mathrm{C}_{s}(1-\mathrm{n}) \rho_{s}=\mathrm{C}_{w} \theta \rho_{w}+\mathrm{C}_{s} \rho_{\mathrm{b}}
$$

where

$\mathrm{C}_{\mathrm{w}}$ specific heat of water, approximately $4184 \mathrm{~J} / \mathrm{kg}^{\circ} \mathrm{C}$;

$\mathrm{C}_{s}$ specific heat of dry rock, approximately $800 \mathrm{~J} / \mathrm{kg}^{\circ} \mathrm{C}$;

$\theta \quad$ volumetric water content, $\mathrm{m}^{3} / \mathrm{m}^{3}$;

$\mathrm{n}$ volumetric porosity, $\mathrm{m}^{3} / \mathrm{m}^{3}$;

$\rho_{w}$ density of water, $\mathrm{kg} / \mathrm{m} 3$;

$\rho_{s}$ grain density of rock, $\mathrm{kg} / \mathrm{m}^{3}$; and

$\rho_{\mathrm{b}}$ bulk density of rock, $\mathrm{kg} / \mathrm{m}^{3}$.

Table 17 summarizes laboratory thermal properties, and Table A17 present data sets for individual laboratory segments.

Table 17: Summary of laboratory thermal conductivity $\left(\mathrm{J} / \mathrm{ms}^{\circ} \mathrm{C}\right)$.

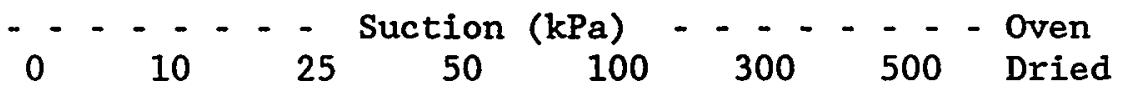

$\begin{array}{lrrrrrrrr}\text { Mean } & 1.821 & 1.800 & 1.820 & 1.775 & 1.817 & 1.729 & 1.727 & 1.266 \\ \text { Coef. Var. } & 10.78 & 9.28 & 10.68 & 11.88 & 11.88 & 11.48 & 10.78 & 11.58 \\ & & & & & & & & \\ \text { Minimum } & 1.291 & 1.381 & 1.464 & 1.356 & 1.382 & 1.445 & 1.095 & 0.829 \\ \text { Median } & 1.839 & 1.792 & 1.801 & 1.758 & 1.779 & 1.696 & 1.717 & 1.281 \\ \text { Maximum } & 2.491 & 2.484 & 2.580 & 3.568 & 2.785 & 2.575 & 2.138 & 1.966\end{array}$




\subsection{Field Thermal Properties}

Potential sources of thermal effects in the unsaturated zone near a HLW repository include surface heating, the geothermal gradient from below; repository waste decay, and latent heating due to phase changes. Surface heating effects result from annual and daily solar cycles, while the geothermal gradient results from heat flux from depth. Temperature profiles are tabulated in Table A18. For the Apache Leap Tuff Site data set, the effects of daily solar.cycles and latent heating are not easily detected and waste decay is not relevant. Only the effects of an annual solar cycle and the geothermal gradient are readily apparent. The geothermal gradient, in turn, appears to be constant, approximating $0.03^{\circ} \mathrm{G} / \mathrm{m}$. Without a measure of the heat flux, however, no estimate of thermal properties can be determined.

The effects of an annual solar cycle can be used to estimate thermal diffusivity at ambient conditions. Carslaw and Jaeger (1959, Eq 2.6.8) present an analytic solution for the temperature distribution in a semiinfinite solid in response to a steady harmonic heating source:

$$
T=A \cos \left(\lambda t-\omega_{0}\right)
$$

where

$\mathrm{T}$ depth and time dependent temperature, ${ }^{\circ} \mathrm{C}$;

A amplitude of the annual solar cycle, ${ }^{\circ} \mathrm{C}$;

$\lambda$ frequency of the annual cycle, $1 / s$;

$t$ time, $s$; and

$\omega_{0}$ phase shift between solar maximum and calendar year.

At any point in the subsurface, the analytic solution takes the form:

$$
T=A \exp (-\nu z) \cos \left(\lambda t-\nu z-\omega_{0}\right)
$$

where $z$ is depth, $m$, and:

$$
\nu=\left(\lambda / 2 D_{t}\right)^{1 / 2}
$$

and $D_{t}$ is the thermal diffusivity, $\mathrm{m}^{2} / \mathrm{s}$. For the ALTS, one estimate of $D_{t}$ can be obtained using the phase shift with depth. By assuming a solar maximum near July 10 , and by noting the depth at which the temperature is a maximum for a given date, effective thermal diffusivities of $0.81,0.23$, 0.57 , and $0.35 \mathrm{E}-6 \mathrm{~m}^{2} / \mathrm{s}$ are estimated using data for $4 / 22 / 87,12 / 18 / 87$, $3 / 23 / 88$ and $12 / 10 / 88$. These value can be compared with data from Table 17 for laboratory cores. Assuming a thermal conductivity of $1.95 \mathrm{~J} / \mathrm{ms}^{\circ} \mathrm{C}$ and a saturated heat capacity of $2.4 \mathrm{E} 6 \mathrm{~J} / \mathrm{m}^{3} \mathrm{C}$, a thermal diffusivity of 0.81 $\mathrm{m}^{2} / \mathrm{s}$ is estimated. The mathematical model will not exactly replicate the physical system, however. In particular, the driving force is not an exact harmonic and the date of the assumed maximum may or may not be accurate. Also, the thermal diffusivity is most likely not a constant, but varies both spatially and temporally due to changes in material properties and moisture content. 


\section{Quantification of Parameter Uncertainties}

The quality assurance goal is to assure the reproducibility of research results and to minimize parameter uncertainties. Uncertainties are introduced by natural variations in parameters due to geologic processes, as well as inaccurate and imprecise measurements and methods. The methods and techniques used to collect, reduce, and interpret research data are designed to be precise, accurate, traceable, and articulated in such a manner that the work can be reproduced and independently evaluated. Written procedures must used for the test design, equipment calibrations, control of procedures, and reports. Various accuracy improvement methods are employed to assure a high degree of precision and accuracy. Methods to minimize and quantify parameter uncertainties include test replication, duplication, and redundancy.

Replication involves repeated sampling using a single instrument which is used to collect information about parameters of interest. Testing is performed multiple times on selected samples if the analysis does not involve destructive testing. If the testing is destructive, testing is performed in conjunction with samples obtained at locations close to each other. The purpose of the replicated sampling is to provide an estimate of the precision of the measurement technique, as well as to provide estimates of spatial variability.

Duplication is the use of a number of identical instruments to measure a specific parameter. Variability induced by inaccurate instruments can be determined using this technique. Wherever possible, multiple instruments of identical manufacture are used to determine the variability induced by each, and to estimate the magnitude of bias generated by using an inaccurate measurement device.

Redundancy is the use of a number of different instruments or techniques to determine system parameters. By estimating parameters using independent techniques, an additional estimate of bias can be obtained. In addition, systematic errors induced by ignoring controlling variables can be examined. This is possible because each technique may not respond in the same way to a controlling variable. Further discussion of the use of multiple analyses and techniques for model specification can be found in Rasmussen (1986).

To demonstrate representative parameter uncertainty analyses, four parameters were evaluated using repetition and duplication procedures. Tables 18 through 21 present data for air permeability, saturated water permeability, relative saturation as a function of matric suction, and unsaturated hydraulic conductivity for selected samples. 
Dry air permeability was estimated for three control samples in two different permeameters on various dates. Samples GA, JA, and MA were repeated in different permeameters, with the coefficient of variation for Permeameters 1 and 2 being computed for Sample GA. The air permeability values measured at two separate times are compared for Sample EH. The results of these experiments are presented as Table 18.

Table 18: Oven dry air permeability for parameter variation estimation.

\begin{tabular}{|c|c|c|c|c|c|}
\hline Sample & Permeameter & Date & Air Permeability & Mean & Coef. Var. \\
\hline GA & $\begin{array}{l}1 \\
1 \\
1 \\
2 \\
2 \\
2\end{array}$ & $\begin{array}{l}11 / 3 / 87 \\
11 / 5 / 87 \\
11 / 5 / 87 \\
11 / 4 / 87 \\
11 / 5 / 87 \\
11 / 6 / 87 \\
F\end{array}$ & $\begin{array}{l}7.40 \times 10-16 \mathrm{~m} 2 \\
6.89 \\
6.82 \\
5.48 \\
5.23 \\
5.09 \\
\text { al1 permeameters: }\end{array}$ & $\begin{array}{l}5.27 \\
6.15\end{array}$ & $\begin{array}{r}3.75 \\
16.22\end{array}$ \\
\hline JA & $\begin{array}{l}1 \\
2 \\
3 \\
3 \\
1\end{array}$ & $\begin{array}{l}11 / 5 / 87 \\
11 / 5 / 87 \\
11 / 5 / 87 \\
11 / 5 / 87 \\
11 / 6 / 87\end{array}$ & $\begin{array}{l}6.28 \\
5.36 \\
5.66 \\
5.69 \\
6.44 \\
\text { al1 permeameters: }\end{array}$ & 5.89 & 7.72 \\
\hline MA & $\begin{array}{l}1 \\
2 \\
2 \\
3 \\
1\end{array}$ & $\begin{array}{l}11 / 3 / 87 \\
11 / 3 / 87 \\
11 / 3 / 87 \\
11 / 5 / 87 \\
11 / 6 / 87 \\
F\end{array}$ & $\begin{array}{l}7.55 \\
6.86 \\
6.79 \\
6.83 \\
7.77 \\
\text { al1 permeameters: }\end{array}$ & 7.16 & 6.48 \\
\hline EH & $\begin{array}{l}3 \\
2 \\
2\end{array}$ & $\begin{array}{l}1 / 31 / 88 \\
1 / 31 / 88 \\
4 / 25 / 88 \\
F\end{array}$ & $\begin{array}{l}9.49 \\
9.53 \\
9.37 \\
\text { all permeameters: }\end{array}$ & 9.46 & 0.88 \\
\hline
\end{tabular}


Saturated hydraulic conductivity tests on Samples AC and AE were repeated in different permeameters. Sample EA has an additional determination 5 months later. Results for the saturated hydraulic conductivity tests are presented as Table 19.

Table 19: Saturated hydraulic permeability for parameter variation estimation.

Sample Permeameter Date Hydraulic Permeability Mean Coef.Var.

\begin{tabular}{|c|c|c|c|c|c|}
\hline $\mathrm{AC}$ & $\begin{array}{l}1 \\
2 \\
3 \\
3\end{array}$ & $\begin{array}{r}11 / 16 / 87 \\
11 / 16 / 87 \\
11 / 16 / 87 \\
11 / 19 / 87 \\
F\end{array}$ & $\begin{array}{l}2.10 \times 10-6 \mathrm{~m} 2 \\
2.05 \\
1.91 \\
2.09 \\
\text { a11 permeameters: }\end{array}$ & 2.04 & 4.308 \\
\hline \multirow[t]{2}{*}{$\mathrm{AE}$} & $\begin{array}{l}2 \\
3 \\
1 \\
1 \\
3\end{array}$ & $\begin{array}{l}11 / 16 / 87 \\
11 / 17 / 87 \\
11 / 18 / 87 \\
11 / 18 / 87 \\
11 / 19 / 87\end{array}$ & $\begin{array}{l}0.88 \\
0.84 \\
1.02 \\
0.93 \\
1.02\end{array}$ & & \\
\hline & & \multicolumn{2}{|c|}{ For all permeameters: } & 0.94 & 8.67 \\
\hline \multirow[t]{2}{*}{ EA } & $\begin{array}{l}3 \\
1 \\
2 \\
2 \\
3\end{array}$ & $\begin{array}{r}11 / 16 / 87 \\
11 / 18 / 87 \\
11 / 19 / 87 \\
11 / 19 / 87 \\
4 / 28 / 88\end{array}$ & $\begin{array}{l}6.62 \\
6.57 \\
6.57 \\
5.92 \\
5.36\end{array}$ & & \\
\hline & & \multicolumn{2}{|c|}{ For all permeameters: } & 6.04 & 10.59 \\
\hline
\end{tabular}


Table 20 presents relative saturation data for two samples. From the table, the coefficient of variation is shown to be approximately three to four percent. The reported coefficient of variation in porosity reported for all samples was approximately thirteen percent. If the assumption can be made that the measurement error is independent of geologic variations, then the total variance is the sum of the geologic variation plus the measurment variance. Using the independence assumption, it can be concluded that the geologic coefficient of variation is about four times the measurement error.

Table 20: Moisture characteristic curves for parameter variation estimation.

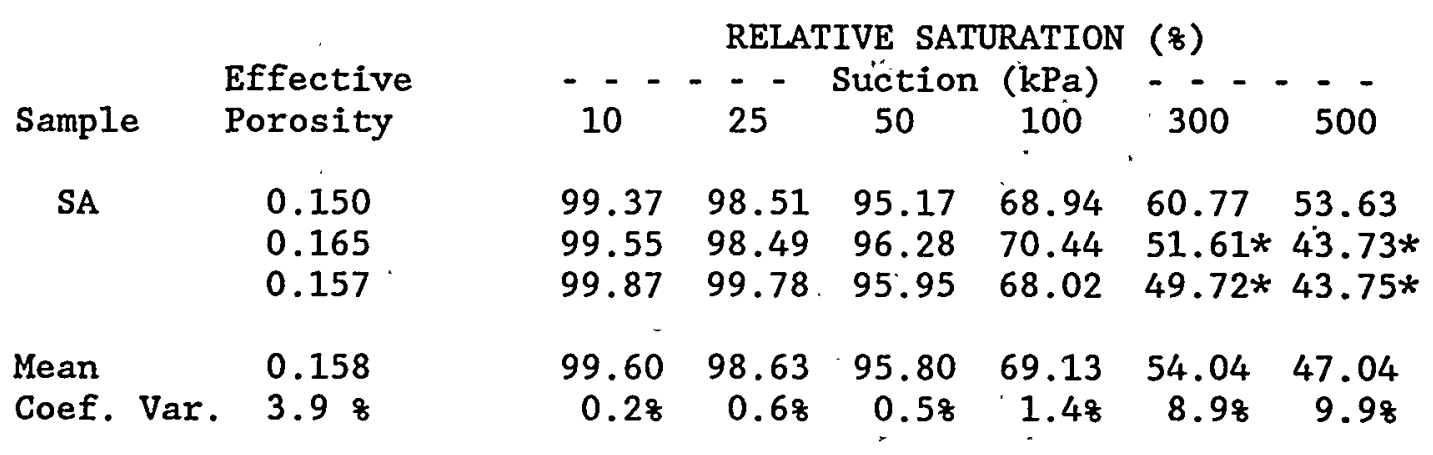

\begin{tabular}{|c|c|c|c|c|c|c|c|}
\hline ample & $\begin{array}{l}\text { Effective } \\
\text { Porosity }\end{array}$ & -- & $\begin{array}{l}\text { RELAT } \\
--- \\
25\end{array}$ & $\begin{array}{l}\text { IVE SATU } \\
\text { Suction } \\
50\end{array}$ & $\begin{array}{l}\text { JRATION } \\
(\mathrm{kPa}) \\
100\end{array}$ & $\begin{array}{l}(8) \\
=-- \\
300\end{array}$ & $-\overline{500}$ \\
\hline UA & $\begin{array}{l}0.160 \\
0.172 \\
0.164\end{array}$ & $\begin{array}{r}99.74 \\
99.60 \\
100.00\end{array}$ & $\begin{array}{l}97.78 \\
98.97 \\
98.85\end{array}$ & $\begin{array}{l}96.25 \\
97.47 \\
97.25\end{array}$ & $\begin{array}{l}78.43 \\
78.10 \\
77.62\end{array}$ & $\begin{array}{l}73.53 \\
57.75 * \\
54.83 *\end{array}$ & $\begin{array}{l}67.14 \\
47.27 * \\
48.38 *\end{array}$ \\
\hline $\begin{array}{l}\text { ean } \\
\text { oef. Var. }\end{array}$ & $\begin{array}{l}0.165 \\
3.28\end{array}$ & $\begin{array}{r}99.87 \\
0.38\end{array}$ & $\begin{array}{r}98.85 \\
0.88\end{array}$ & $\begin{array}{r}96.99 \\
0.68\end{array}$ & $\begin{array}{r}78.05 \\
0.48\end{array}$ & $\begin{array}{l}62.03 \\
13.28\end{array}$ & $\begin{array}{l}54.26 \\
16.88\end{array}$ \\
\hline
\end{tabular}

* Different pressure plate used. 
Unsaturated hydraulic conductivity tests for one of two samples, GC or UC, were run once every tenth sample. Sample GC was tested in the same permeameter while sample UC was tested repeatedly in a different permeameter. Table 21 presents the test results. As can be observed in the table, the coefficient of variation increased for the sample tested in different permeameters over the coefficient of variation for the sample tested in the same peremeameter.

Table 21: Unsaturated hydraulic conductivity values for parameter variation estimation.

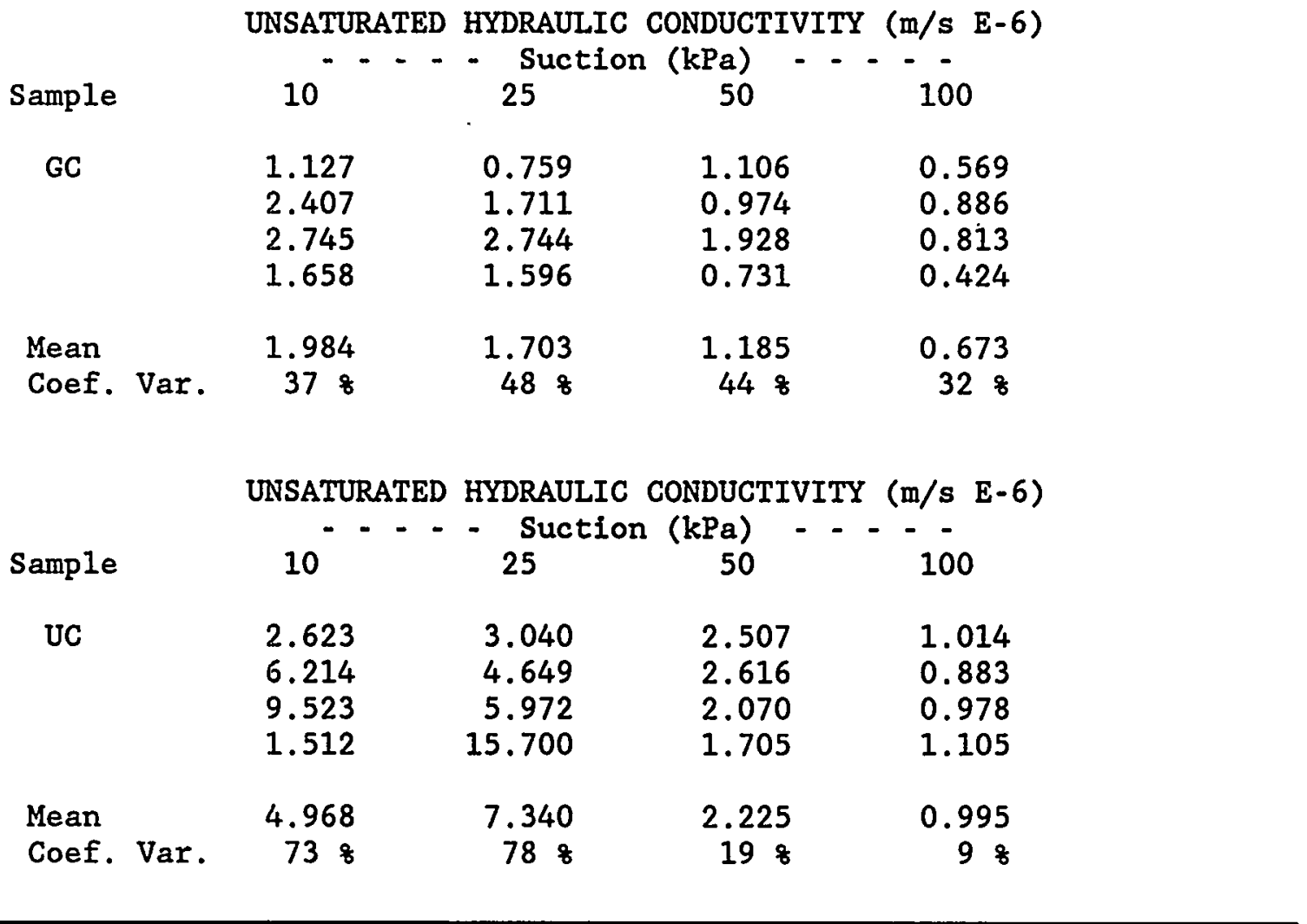




\section{Summary}

Data sets for the interstitial, hydraulic, pneumatic and thermal properties of unsaturated fractured tuff at the Apache Leap Tuff Site (ALTS) in central Arizona are presented for both the rock matrix and embedded fractures. The properties are reported for core segments collected at 105 locations in nine boreholes, as well as for field tests over three meter intervals. Estimates from the core segments are compared to field test's whenever possible. Summary statistics for core and field data are also presented.

The reported interstitial properties include the bulk and grain densities, effective porosity and pore area for the rock matrix, along-with fracture location, density, orientation, interconnectivity and porosity. Rock bulk densities are near $2.1 \mathrm{Mg} / \mathrm{m}^{3}$, grain densities are approximately $2.55 \mathrm{Mg} / \mathrm{m}^{3}$, effective porosities are near 17.5 percent and pore areas are approximately $3500 \mathrm{~m}^{2} / \mathrm{kg}$. Logging of fractures from core data yield fracture densities of 0.77 per meter and predominately vertical orientations, striking N20W.

Saturated hydraulic conductivities estimated in the laboratory for unfractured core segments yield a mean value of $20 \times 10^{-9} \mathrm{~m} / \mathrm{s}$, with individual segments varying over three orders of magnitude. Field estimates are larger, ranging from 29 to $59 \times 10^{-9} \mathrm{~m} / \mathrm{s}$ depending upon the method used to calculate the conductivity estimate. The range of field values is also larger, covering five orders of magnitude, due to the presence of fracture flow during field tests. Calibration of a neutron probe provided the ability to monitor field water contents, observed to be approximately 75 percent of saturation.

Pneumatic properties include laboratory and field estimates. Laboratory estimates of oven-dry pneumatic permeability are larger than hydraulic.. permeabilities of saturated samples, explained by the presence of slip flow. The ratio of the permeabilities provides an estimate of the Klinkenberg coefficient, approximately $322 \mathrm{kPa}$.

Thermal properties of the rock include the thermal conductivity, diffusivity, and heat capacity. The effect of relative saturation on thermal conductivity is negligible except for very dry rock. Saturated heat conductivities of $1.8 \mathrm{~J} / \mathrm{ms}^{\circ} \mathrm{C}$ are found in the laboratory. Laboratory estimates of thermal diffusivity compare favorable with field estimates based on the observed lag between annual surface heating and temperature peaks in the subsurface.

All data sets demonstrate variation as a function of location as well as between estimation techniques. For some parameters (e.g., matrix grain and bulk densities) the variance is small among samples and estimation techniques. Other parameters (e.g., effective matrix porosity) demonstrates substantial spatial variability as well as only a fair agreement between eștimation techniques. 


\section{References}

Anderson, Ingrid, 1987, Measurement of Unsaturated Rock-Water Potential In Situ, M.S. Thesis, University of Arizona.

Barackman, M.L., 1986, Diverging Flow Tracer Tests in Fractured Granite: Equipment Design and Data Collection, M.S. Thesis, University of Arizona, $72 \mathrm{pp}$.

Carslaw, H.S. and J.C. Jaeger, 1959, Conduction of Heat in Solids, Clarendon Press, $510 \mathrm{pp}$.

Dachler, 1936, cited from Hvorslev, M.J., 1951, Time Lag and Soil Permeability in Groundwater Observations, Bulletin 36, US Army Eng. Waterways Exp. Sta., Vicksburg, Miss.

Davies, Bill, 1987, Measurement of Thermal Conductivity and Diffusivity in an Unsaturated, Welded Tuff, M.S. Thesis, University of Arizona.

Elder, Alexander N., 1988, Theoretical'Calibration of Neutron Gauges, M.S. Thesis, University of Arizona.

Evans, D.D., 1983, Unsaturated Flow and Transport Through Fractured Rock Related to High-Level Waste Repositories, NUREG/CR-3206, 231 pp.

Gelhar, L.W., 1982, Analysis of Two-Well Tracer Tests with a Pulse Input, RHO-BW-CR-131 P.

Glover, R.E., 1953, Flow From a Test-Hole Above Groundwater Level, in Theory and Problems of Water Percolation, U.S. Bureau of Reclamation Engineering Monograph No. 8, p. 66-71.

Goodman, R.E., 1976, Methods of Geological Engineering in Discontinuous Rocks, West Publishing, 472 pp.

Grimestad, G., 1981, Inverse Solutions of the Theis Equation Determined with Programmable Calculators, Ground Water, 19(4):387-391.

Klinkenberg, L.J., 1941, The Permeability of Porous Media to Liquids and Gases, Am. Pet. Inst., Drilling and Production Practice.

Klute, A., 1964, Water Diffusivity, in Methods of Soil Analysis, Part 1,

Am. Soc. Agron., Soil Sci. Soc. Am., 262:272.

Kool, J.B. and J.C. Parker, 1987, SFIT: Estimating Soil Hydraulic Properties from Transient Flow Experiments, User's Guide, v. 1.0, Soil and Environmental Sciences, Agron. Dept., Virginia Tech, Blacksburg, VA.

Micromeritics, 1986, Instruction Manual for Poresizer 9310.

Peterson, D.W., 1961, Dacitic Ash-Flow Sheet Near Superior and Globe, Arizona, Ph.D. Dissertation, Stanford University.

Peterson, D.W., 1968, Zoned Ash-Flow Sheet in the Region Around Superior, Arizona, in Titley, S.R. (ed.), Southern Arizona Guidebook III, Geol. Soc. Am., p. 215-222.

Philip, J.R., 1985, Approximate Analysis of the Borehole Permeameter in Unsaturated Soil, Water Resour. Res., 21(7):1025-1033.

Rasmussen, T.C., 1986, Improved Site Characterization Using Multiple Approaches, in Groundwater Flow and Transport Modeling for Performance Assessment of Deep Geologic Disposal of Radioactive Waste, NUREG/CP0079 , pp. 101-113.

Rasmussen, T.C. and D.D. Evans, 1987, Unsaturated Flow and Transport Through Fractured Rock - Related To High-Level Waste Repositories, Phase II, NUREG/CR-4655, 475 pp. 
Thorstenson, D.C. and D.W. Pollock, 1989, Gas Transport in Unsaturated Porous Media: The Adequacy of Fick's Law, Review of Geophysics, 27(1):$61-78$.

Tidwell, V.C., 1988, Determination of the Equivalent Saturated Hydraulic Conductivity of Fractured Rock Located in the Vadose Zone, M.S. Thesis, University of Arizona, 135 pp.

Tidwe11, V.C., T.C. Rasmussen, and D.D. Evans, 1988, Saturated Hydraulic Conductivity Estimates for Fractured Rock in the Unsaturated Zone, Proc. of International Conference and Workshop on the Validation of Flow and Transport Models for the Unsaturated Zone, Ruidoso, N.M., May 25-28.

Tsang, Y.W. and K. Pruess, 1987, A Study of Thermally Induced Convection Near a High-Level Nuclear Waste Repository in Partially Saturated Fractured Tuff, Water Resour. Res., 23(3):467-480.

Van Genuchten, R., 1978, Calculating the Unsaturated Hydraulic Conductivity with a New Closed-Form Analytical Mode1, Research Report 78-WR-08, Princeton University, N.J., 50 pp.

Van Genuchten, R., 1980, "A Closed-Form Equation for Predicting the Hydraulic Conductivity of Unsaturated Soils", Soil Sci. Am. J., (44):892-898.

Vogt, G.T., 1988, Porosity, Pore-Size Distribution and Pore Surface Area of the Apache Leap Tuff Near Superior, Arizona Using Mercury Intrusion, 130 pp.

Weber, D., 1986, Mineralogic, Isotopic and Spatial Properties of Fractures In an Unsaturated Partially-Welded Tuff near Superior, Arizona, M.S. Thesis, University of Arizona, Tucson, $128 \mathrm{pp}$.

Yeh, T.-C.J., T.C. Rasmussen and D.D. Evans, 1988, Simulation of Liquid and Vapor Movement in Unsaturated Fractured Rock at the Apache Leap Tuff Site: Models and Strategies, NUREG/CR-5097, $73 \mathrm{pp}$.

Zimmer, P.W., 1963, Orientation of Small Diameter Drill Core, Econ. Geol., $58: 1313-1325$. 
Table Al: Local coordinates in meters of borehole casing 1ip, ground surface and borehole bottom at the Apache Leap Tuff site. $(x, y)$ plane is perpendicular to local gravity vector, $z$, directed upward.

\begin{tabular}{|c|c|c|c|c|c|c|c|c|c|}
\hline & $(\mathrm{x})^{\mathrm{Ca}}$ & $\begin{array}{l}\text { ing Lip } \\
(y)\end{array}$ & $\begin{array}{l}(\mathrm{m}) \\
(\mathrm{z})\end{array}$ & $\begin{array}{l}\text { Ground } \\
\text { (x) }\end{array}$ & $\begin{array}{l}\text { Surface } \\
\text { (y) }\end{array}$ & $\begin{array}{l}(\mathrm{m}) \\
(\mathrm{z})\end{array}$ & $\begin{array}{c}\text { Boreho } \\
\text { (x) }\end{array}$ & $\begin{array}{c}\text { le Bott } \\
(y)\end{array}$ & $\begin{array}{c}\text { tom (m) } \\
(z)\end{array}$ \\
\hline $\begin{array}{l}X 1 \\
X 2 \\
X 3\end{array}$ & $\begin{array}{r}0.00 \\
10.12 \\
20.15\end{array}$ & $\begin{array}{l}0.00 \\
0.01 \\
0.00\end{array}$ & $\begin{array}{r}0.00 \\
-0.05 \\
0.00\end{array}$ & $\begin{array}{r}0.00 \\
9.14 \\
19.02\end{array}$ & $\begin{array}{l}0.00 \\
0.01 \\
0.08\end{array}$ & $\begin{array}{l}-0.95 \\
-0.38 \\
-0.33\end{array}$ & $\begin{array}{l}-13.68 \\
-13.16 \\
-12.52\end{array}$ & $\begin{array}{l}0.00 \\
0.01 \\
0.00\end{array}$ & $\begin{array}{l}-13.68 \\
-23.33 \\
-32.68\end{array}$ \\
\hline $\begin{array}{l}\text { Y1 } \\
\text { Y2 } \\
\text { Y3 }\end{array}$ & $\begin{array}{r}-0.12 \\
9.75 \\
19.78\end{array}$ & $\begin{array}{l}-4.94 \\
-4.85 \\
-4.68\end{array}$ & $\begin{array}{l}-0.04 \\
-0.34 \\
-0.32\end{array}$ & $\begin{array}{r}-1.15 \\
8.65 \\
19.04\end{array}$ & $\begin{array}{l}-4.81 \\
-4.74 \\
-4.61\end{array}$ & $\begin{array}{l}-0.33 \\
-0.59 \\
-0.61\end{array}$ & $\begin{array}{l}-12.29 \\
-12.26 \\
-12.04\end{array}$ & $\begin{array}{l}-4.94 \\
-4.85 \\
-4.68\end{array}$ & $\begin{array}{l}-12.21 \\
-22.35 \\
-32.14\end{array}$ \\
\hline $\begin{array}{l}\mathrm{Z} 1 \\
\mathrm{Z2} \\
\mathrm{Z3}\end{array}$ & $\begin{array}{r}9.25 \\
-0.58 \\
-10.31\end{array}$ & $\begin{array}{r}-10.04 \\
-9.99 \\
-10.04\end{array}$ & $\begin{array}{l}-0.36 \\
-0.21 \\
-0.02\end{array}$ & $\begin{array}{r}10.17 \\
1.05 \\
-9.32\end{array}$ & $\begin{array}{l}-9.96 \\
-9.95 \\
-9.96\end{array}$ & $\begin{array}{l}-0.56 \\
-0.54 \\
-0.23\end{array}$ & $\begin{array}{l}21.32 \\
21.66 \\
21.64\end{array}$ & $\begin{array}{r}-10.04 \\
-9.99 \\
-10.04\end{array}$ & $\begin{array}{l}-12.43 \\
-22.59 \\
-31.67\end{array}$ \\
\hline
\end{tabular}


Table A2: Location of borehole samples at the Apache Leap Tuff Site.

Depth is inclined distance along borehole.

\begin{tabular}{|c|c|c|c|c|c|}
\hline ID & $\begin{array}{l}\text { Depth } \\
\text { (m) }\end{array}$ & ID & $\begin{array}{l}\text { Depth } \\
\text { (m) }\end{array}$ & ID & $\begin{array}{l}\text { Depth } \\
\text { (m) }\end{array}$ \\
\hline $\mathrm{X1}$ : & & Y1: & & Z1: & \\
\hline AA & 2.1 & GB & 1.8 & PB & 1.8 \\
\hline$A B$ & 3.0 & GC & 3.3 & PC & 3.0 \\
\hline $\mathrm{AC}$ & 3.8 & GD & 4.1 & PD & 4.0 \\
\hline$A D$ & 6.9 & GA & 6.6 & $\mathrm{PE}$ & 5.9 \\
\hline $\mathrm{AE}$ & 10.0 & GF & 9.9 & PF & 9.2 \\
\hline $\mathrm{AF}$ & 12.7 & GG & 12.2 & PG & 12.4 \\
\hline AG & 15.8 & $\mathrm{GH}$ & 15.7 & $\mathrm{PH}$ & 15.3 \\
\hline $\mathrm{X} 2:$ & & Y2: & & Z2: & \\
\hline $\mathrm{CA}$ & 1.8 & JB & 1.8 & SB & 2.0 \\
\hline CB & 2.8 & $\mathrm{JC}$ & 3.3 & SC & 3.0 \\
\hline CC & 3.5 & JD & 4.1 & $S D$ & 4.0 \\
\hline CD & 6.6 & $\mathrm{JE}$ & 6.2 & $\mathrm{SE}$ & 6.5 \\
\hline $\mathrm{CE}$ & 10.0 & JF & 9.3 & SF & 9.3 \\
\hline CF & 12.7 & JG & 12.3 & SG & 12.4 \\
\hline CG & 16.1 & $\mathrm{JH}$ & 15.3 & SH & 15.3 \\
\hline $\mathrm{CH}$ & 18.5 & JJ & 18.5 & SJ & 18.7 \\
\hline CJ & 21.6 & $\mathrm{JK}$ & 21.3 & SK & 21.3 \\
\hline CK & 24.7 & JM & 24.5 & SM & 24.5 \\
\hline CM & 27.9 & JN & 27.3 & SN & 27.4 \\
\hline CN & 30.8 & JP & 30.3 & SP & 30.5 \\
\hline X3: & & Y3: & & Z3: & - \\
\hline EA & 1.8 & MB & 2.0 & UW & 2.0 \\
\hline$E B$ & 2.7 & MC & 3.1 & UC & 3.0 \\
\hline$\overline{E C}$ & 3.8 & MD & 4.1 & UD & 3.8 \\
\hline ED & 6.8 & $\mathrm{ME}$ & 6.2 & UE & 6.6 \\
\hline $\mathrm{EE}$ & 9.9 & $\mathrm{MF}$ & 9.3 & UF & 9.8 \\
\hline$\overline{E F}$ & 12.9 & MG & 12.4 & UG & 12.7 \\
\hline EG & 15.8 & MH & 16.0 & $\mathrm{UH}$ & 15.8 \\
\hline $\mathrm{EH}$ & 18.8 & $\mathrm{MJ}$ & 18.2 & UJ & 18.8 \\
\hline EJ & 21.6 & MK & 21.4 & UK & 21.6 \\
\hline EK & 24.7 & $\mathrm{MM}$ & 24.2 & UM & 24.7 \\
\hline EM & 27.7 & $\mathrm{MN}$ & 27.4 & UN & 27.7 \\
\hline EN & 31.0 & MP & 30.3 & UP & 30.7 \\
\hline $\mathrm{EP}$ & 33.7 & MR & 33.2 & UR & 33.7 \\
\hline ER & 36.9 & MS & 36.5 & US & 36.8 \\
\hline ES & 39.9 & $\mathrm{MT}$ & 39.3 & UT & 39.7 \\
\hline ET & 42.9 & MU & 42.1 & UU & 42.9 \\
\hline
\end{tabular}


Table A3: Bulk and skeletal densities, in $\mathrm{Mg} / \mathrm{m}^{3}$ for three core segment sizes at 105 locations at the Apache Leap Tuff Site.

\begin{tabular}{ccccccc} 
Sample & \multicolumn{2}{c}{ Bulk } & Density & $\left(\mathrm{Mg} / \mathrm{m}^{3}\right)$ & Skeletal & Density \\
ID & small & medium & large & small & medium & large \\
& & & & & & \\
X1 AA & 1.99 & 2.11 & 2.11 & 2.43 & 2.37 & 2.56 \\
AB & 2.02 & 2.13 & 2.13 & 2.34 & 2.42 & 2.55 \\
AC & 1.99 & 2.15 & 2.13 & 2.33 & 2.48 & 2.59 \\
AD & 2.05 & 2.18 & 2.12 & 2.46 & 2.46 & 2.54 \\
AE & 1.94 & 2.18 & 1.99 & 2.32 & 2.50 & 2.34 \\
AF & 1.88 & 2.16 & 2.18 & 2.28 & 2.54 & 2.60 \\
AG & 1.88 & 2.16 & 2.18 & 2.24 & 2.52 & 2.60 \\
& & & & & & \\
X2 CA & 1.94 & 2.08 & 1.97 & 2.46 & 2.43 & 2.50 \\
CB & 1.90 & 2.04 & 2.06 & 2.35 & 2.26 & 2.54 \\
CC & 1.98 & 2.03 & 2.04 & 2.36 & 2.27 & 2.51 \\
CD & 2.04 & 2.14 & 2.12 & 2.40 & 2.47 & 2.48 \\
CE & 2.07 & 2.11 & 2.13 & 2.46 & 2.51 & 2.57 \\
CF & 1.90 & 2.13 & 2.00 & 2.29 & 2.51 & 2.44 \\
CG & 2.09 & 2.00 & 2.06 & 2.47 & 2.44 & 2.52 \\
CH & 2.09 & 2.18 & 2.07 & 2.44 & 2.56 & 2.57 \\
CJ & 1.85 & 2.17 & 2.15 & 2.35 & 2.53 & 2.59 \\
CK & 1.88 & 2.15 & 2.06 & 2.30 & 2.56 & 2.56 \\
CM & 2.00 & 2.10 & 2.09 & 2.43 & 2.51 & 2.58 \\
CN & 1.98 & 2.15 & 2.09 & 2.33 & 2.55 & 2.59 \\
& & & & & & \\
X3 EA & 1.85 & 1.94 & 2.04 & 2.45 & 2.21 & 2.58 \\
EB & 2.05 & 2.01 & 1.97 & 2.47 & 2.34 & 2.47 \\
EC & 1.93 & 2.07 & 2.00 & 2.41 & 2.45 & 2.47 \\
ED & 2.01 & 2.13 & 2.10 & 2.40 & 2.44 & 2.51 \\
EE & 2.06 & 2.15 & 2.16 & 2.42 & 2.47 & 2.55 \\
EF & 2.07 & 2.18 & 2.15 & 2.41 & 2.51 & 2.52 \\
EG & 1.90 & 2.23 & 2.14 & 2.27 & 2.57 & 2.54 \\
EH & 2.10 & 2.16 & 2.19 & 2.43 & 2.53 & 2.56 \\
EJ & 2.12 & 2.20 & 2.16 & 2.38 & 2.51 & 2.56 \\
EK & 2.02 & 2.19 & 2.17 & 2.35 & 2.55 & 2.58 \\
EM & 2.00 & 2.25 & 2.16 & 2.40 & 2.56 & 2.58 \\
EN & 2.05 & 2.11 & 2.07 & 2.40 & 2.52 & 2.50 \\
EP & 1.97 & 2.10 & 2.12 & 2.44 & 2.54 & 2.56 \\
ER & 1.98 & 2.19 & 2.12 & 2.41 & 2.59 & 2.56 \\
ES & 2.03 & 2.15 & 2.11 & 2.42 & 2.53 & 2.58 \\
ET & 2.03 & 2.11 & 2.12 & 2.41 & 2.50 & 2.57
\end{tabular}


Table A3 (Continued)

\begin{tabular}{|c|c|c|c|c|c|c|}
\hline $\begin{array}{l}\text { Sample } \\
\text { ID }\end{array}$ & $\begin{array}{r}\text { Bulk } \\
\text { small }\end{array}$ & $\begin{array}{l}\text { Density } \\
\text { medium }\end{array}$ & $\begin{array}{c}\left(\mathrm{Mg} / \mathrm{m}^{3}\right) \\
\text { large }\end{array}$ & $\begin{array}{c}\text { Skeletal } \\
\text { small }\end{array}$ & $\begin{array}{l}\text { Density } \\
\text { medium }\end{array}$ & $\begin{array}{l}\left(\mathrm{Mg} / \mathrm{m}^{3}\right) \\
\text { large }\end{array}$ \\
\hline Y1 GB & 2.04 & 2.12 & 2.17 & 2.40 & 2.46 & 2.60 \\
\hline GC & 2.01 & 2.15 & 2.14 & 2.34 & 2.44 & 2.56 \\
\hline$G D$ & 2.00 & 2.14 & 2.13 & 2.34 & 2.47 & 2.56 \\
\hline GA & 2.00 & 2.10 & 2.13 & 2.34 & 2.43 & 2.55 \\
\hline GF & 1.85 & 2.11 & 2.09 & 2.26 & 2.53 & 2.57 \\
\hline GG & 1.97 & 2.13 & 2.13 & 2.35 & 2.54 & 2.53 \\
\hline GH & 2.11 & 2.18 & 2.17 & 2.48 & 2.54 & 2.57 \\
\hline Y2 JB & 1.77 & 2.02 & 2.01 & 2.26 & 2.43 & 2.63 \\
\hline JC & 1.91 & 2.25 & 2.04 & 2.41 & 2.56 & 2.52 \\
\hline JD & 1.75 & 2.21 & 2.08 & 2.23 & 2.55 & 2.55 \\
\hline $\mathrm{JE}$ & 2.03 & 2.12 & 2.08 & 2.37 & 2.62 & 2.51 \\
\hline $\mathrm{JF}$ & 1.89 & 2.10 & 2.13 & 2.30 & 2.41 & 2.58 \\
\hline JG & 2.01 & 2.13 & 2.04 & 2.39 & 2.50 & 2.58 \\
\hline $\mathrm{JH}$ & 1.86 & 2.11 & 2.11 & 2.43 & 2.51 & 2.57 \\
\hline $\mathrm{JJ}$ & 1.97 & 2.17 & 2.00 & 2.48 & 2.52 & 2.53 \\
\hline JK & 1.76 & 2.14 & 2.11 & 2.33 & 2.54 & 2.54 \\
\hline JM & 1.83 & 2.07 & 2.08 & 2.28 & 2.50 & 2.53 \\
\hline $\mathrm{JN}$ & 2.03 & 2.15 & 2.08 & 2.40 & 2.57 & 2.53 \\
\hline $\mathrm{JP}$ & 1.96 & 2.19 & 2.12 & 2.35 & 2.50 & 2.61 \\
\hline Y3 MB & 1.92 & 1.99 & 2.02 & 2.45 & 2.32 & 2.54 \\
\hline MC & 1.98 & 1.94 & 2.03 & 2.45 & 2.28 & 2.61 \\
\hline MD & 1.93 & 2.14 & 2.05 & 2.41 & 2.72 & 2.64 \\
\hline $\mathrm{ME}$ & 1.97 & 2.15 & 2.01 & 2.39 & 2.52 & 2.48 \\
\hline MF & 2.06 & 2.15 & 2.17 & 2.44 & 2.57 & 2.53 \\
\hline MG & 1.81 & 2.02 & 1.90 & 2.39 & 2.44 & 2.62 \\
\hline MH & 1.91 & 2.11 & 2.10 & 2.47 & 2.47 & 2.55 \\
\hline MJ & 2.14 & 2.23 & 2.18 & 2.47 & 2.55 & 2.55 \\
\hline MK & 2.11 & 2.24 & 2.20 & 2.48 & 2.55 & 2.57 \\
\hline MM & 2.07 & 2.23 & 2.15 & 2.44 & 2.59 & 2.52 \\
\hline $\mathrm{MN}$ & 2.02 & 2.20 & 2.15 & 2.38 & 2.58 & 2.56 \\
\hline MP & 2.08 & 2.16 & 2.14 & 2.48 & 2.56 & 2.60 \\
\hline MR & 2.00 & 2.19 & 2.17 & 2.44 & 2.59 & 2.62 \\
\hline MS & 2.05 & 2.10 & 2.12 & 2.48 & 2.54 & 2.59 \\
\hline MT & 2.00 & 2.09 & 2.13 & 2.49 & 2.55 & 2.57 \\
\hline MU & 2.17 & 2.15 & 2.15 & 2.45 & 2.55 & 2.59 \\
\hline
\end{tabular}


Table A3 (Continued)

\begin{tabular}{|c|c|c|c|c|c|c|c|}
\hline \multicolumn{2}{|c|}{$\begin{array}{l}\text { Sample } \\
\text { ID }\end{array}$} & $\begin{array}{l}\text { Bulk } \\
\text { small }\end{array}$ & $\begin{array}{l}\text { Density } \\
\text { medium }\end{array}$ & $\begin{array}{c}\left(\mathrm{Mg} / \mathrm{m}^{3}\right) \\
\text { large }\end{array}$ & $\begin{array}{c}\text { Skeletal } \\
\text { small }\end{array}$ & $\begin{array}{l}\text { Density } \\
\text { medium }\end{array}$ & $\begin{array}{l}\left(\mathrm{Mg} / \mathrm{m}^{3}\right) \\
\text { large }\end{array}$ \\
\hline \multirow[t]{7}{*}{$\mathrm{Z1}$} & PB & 1.92 & 2.15 & 1.94 & 2.40 & 2.47 & 2.37 \\
\hline & PC & 1.92 & 2.07 & 2.03 & 2.40 & 2.39 & 2.47 \\
\hline & $\mathrm{PD}$ & 1.96 & 2.05 & 2.07 & 2.40 & 2.44 & 2.68 \\
\hline & $\mathrm{PE}$ & 1.99 & 2.10 & 2.11 & 2.40 & 2.37 & 2.50 \\
\hline & $\mathrm{PF}$ & 2.00 & 2.19 & 2.16 & 2.37 & 2.48 & 2.55 \\
\hline & PG & 1.99 & 2.13 & 2.09 & 2.37 & 2.41 & 2.52 \\
\hline & $\mathrm{PH}$ & 1.99 & 2.12 & 2.12 & 2.47 & 2.49 & 2.51 \\
\hline \multirow[t]{12}{*}{$\mathrm{Z2}$} & SB & 2.01 & 2.18 & 2.14 & 2.43 & 2.53 & 2.60 \\
\hline & SC & 2.06 & 2.20 & 2.18 & 2.44 & 2.51 & 2.61 \\
\hline & SD & 2.00 & 2.08 & 2.11 & 2.44 & 2.38 & 2.54 \\
\hline & $S E$ & 2.04 & 2.13 & 2.11 & 2.44 & 2.50 & 2.54 \\
\hline & SF & 2.01 & 2.06 & 2.03 & 2.43 & 2.47 & 2.56 \\
\hline & SG & 2.05 & 1.94 & 1.86 & 2.40 & 2.22 & 2.51 \\
\hline & SH & 2.03 & 2.03 & 2.08 & 2.40 & 2.36 & 2.51 \\
\hline & SJ & 2.07 & 2.10 & 2.13 & 2.45 & 2.44 & 2.54 \\
\hline & SK & 1.94 & 2.10 & 2.17 & 2.34 & 2.41 & 2.54 \\
\hline & SM & 2.05 & 2.17 & 2.17 & 2.40 & 2.50 & 2.54 \\
\hline & SN & 1.98 & 2.15 & 2.15 & 2.45 & 4.11 & 2.53 \\
\hline & SP & 1.99 & 2.08 & 2.06 & 2.42 & 2.55 & 2.50 \\
\hline \multirow[t]{16}{*}{$\mathrm{Z3}$} & UW & 2.05 & 2.23 & 2.17 & 2.38 & 2.55 & 2.58 \\
\hline & UC & 2.04 & 2.16 & 2.12 & 2.38 & 2.51 & 2.55 \\
\hline & UD & 2.06 & 2.14 & 2.05 & 2.39 & 2.52 & 2.53 \\
\hline & UE & 2.06 & 2.10 & 2.10 & 2.47 & 2.31 & 2.54 \\
\hline & UF & 2.04 & 2.08 & 2.10 & 2.45 & 2.44 & 2.52 \\
\hline & UG & 1.99 & 2.17 & 2.06 & 2.42 & 2.56 & 2.56 \\
\hline & $\mathrm{UH}$ & 2.03 & 2.06 & 2.00 & 2.45 & 2.33 & 2.48 \\
\hline & UJ & 1.92 & 2.19 & 2.16 & 2.40 & 2.52 & 2.54 \\
\hline & UK & 2.00 & 2.25 & 2.18 & 2.40 & 2.56 & 2.57 \\
\hline & UM & 2.04 & 2.18 & 2.16 & 2.41 & 2.56 & 2.57 \\
\hline & UN & 2.05 & 2.23 & 2.19 & 2.43 & 2.63 & 2.59 \\
\hline & UP & 2.17 & 2.22 & 2.18 & 2.53 & 2.50 & 2.56 \\
\hline & UR & 2.04 & 2.19 & 2.14 & 2.47 & 2.59 & 2.59 \\
\hline & US & 1.88 & 2.13 & 2.09 & 2.48 & 2.56 & 2.50 \\
\hline & UT & 2.07 & 2.14 & 2.11 & 2.46 & 2.58 & 2.54 \\
\hline & UU & 2.03 & 2.19 & 2.12 & 2.43 & 2.56 & 2.54 \\
\hline
\end{tabular}


Table A4: Effective porosity for three core segment sizes and pore area values for small core segment sizes at 105 locations at the Apache Leap Tuff Site.

\begin{tabular}{crrrr} 
Sample & \multicolumn{2}{l}{ Effective Porosity $(8)$} & Pore Area \\
ID & smal1 & medium large & $\left(\mathrm{m}^{2} / \mathrm{kg}\right)$ \\
X1 AA & 17.84 & 10.91 & 17.61 & \\
AB & 13.97 & 11.84 & 16.34 & 3008. \\
AC & 14.68 & 13.50 & 17.45 & 3092. \\
AD & 16.60 & 12.40 & 16.63 & 3163. \\
AE & 16.02 & 12.80 & 15.16 & 3623. \\
AF & 17.51 & 15.10 & 16.23 & 3172. \\
AG & 16.20 & 14.10 & 16.20 & 3241. \\
& & & & \\
X2 CA & 21.05 & 14.20 & 21.10 & 4939. \\
CB & 19.10 & 9.80 & 18.79 & 2666. \\
CC & 16.28 & 10.50 & 18.80 & 3128. \\
CD & 15.04 & 13.50 & 14.56 & 2961. \\
CE & 15.67 & 15.85 & 17.39 & 3208. \\
CF & 17.07 & 15.31 & 17.87 & 3072. \\
CG & 15.56 & 17.94 & 18.38 & 3362. \\
CH & 14.57 & 14.88 & 19.56 & 3158. \\
CJ & 20.99 & 14.19 & 16.92 & 2938. \\
CK & 18.45 & 16.13 & 20.52 & 3435. \\
CM & 17.63 & 16.33 & 19.07 & 3594. \\
CN & 15.23 & 15.91 & 19.53 & 3081. \\
& & & & \\
X3 EA & 24.73 & 12.20 & 20.71 & 3202. \\
EB & 16.94 & 14.36 & 20.15 & 4145. \\
EC & 19.80 & 15.40 & 18.82 & 3232. \\
ED & 16.47 & 12.80 & 16.41 & 2812. \\
EE & 14.92 & 13.20 & 14.96 & 2934. \\
EF & 14.04 & 13.09 & 14.80 & 2825. \\
EG & 16.54 & 13.23 & 15.68 & 2963. \\
EH & 13.70 & 14.31 & 14.30 & 2843. \\
EJ & 11.02 & 12.55 & 15.37 & 2207. \\
EK & 14.32 & 14.02 & 15.96 & 2813. \\
EM & 16.57 & 12.27 & 16.22 & 2852. \\
EN & 16.52 & 16.34 & 17.26 & 3492. \\
EP & 19.19 & 17.47 & 17.35 & 2925. \\
ER & 17.91 & 15.38 & 17.49 & 2877. \\
ES & 16.16 & 14.91 & 18.31 & 3408. \\
ET & 15.79 & 15.39 & 17.42 & 3319.
\end{tabular}


Table A4 (Continued)

\begin{tabular}{ccccc} 
Sample & \multicolumn{3}{c}{ Effective Porosity $(8)$} & Pore Area \\
ID & smal1 & medium & large & $\left(\mathrm{m}^{2} / \mathrm{kg}\right)$ \\
Y1 GB & 14.99 & 13.70 & 16.71 & 3258. \\
GC & 14.35 & 11.90 & 16.62 & 3315. \\
GD & 14.41 & 13.33 & 16.69 & 3673. \\
GA & 14.78 & 13.93 & 16.37 & 3312. \\
GF & 18.35 & 16.61 & 18.82 & 2776. \\
GG & 16.19 & 15.99 & 15.96 & 2524. \\
GH & 15.25 & 11.22 & 15.65 & 2667. \\
& & & & \\
Y2 JB & 21.61 & 16.65 & 23.40 & 4051. \\
JC & 20.56 & 12.20 & 19.16 & 3429. \\
JD & 21.73 & 13.30 & 18.61 & 5364. \\
JE & 14.34 & 19.00 & 16.87 & 16160. \\
JF & 17.86 & 12.83 & 17.21 & 2291. \\
JG & 15.89 & 14.95 & 20.64 & 3286. \\
JH & 23.55 & 15.94 & 18.18 & 3077. \\
JJ & 20.55 & 13.76 & 20.82 & 2916. \\
JK & 24.30 & 16.03 & 16.90 & 2819. \\
JM & 19.75 & 17.37 & 17.59 & 3570. \\
JN & 15.49 & 16.60 & 17.63 & 3222. \\
JP & 16.64 & 12.38 & 18.67 & 2500. \\
Y3 MB & 21.67 & 14.40 & 20.48 & 10069. \\
MC & 19.15 & 14.90 & 21.97 & 16513. \\
MD & 19.83 & 21.20 & 22.43 & 13743. \\
ME & 19.44 & 14.64 & 18.86 & 2812. \\
MF & 15.58 & 16.42 & 14.33 & 3302. \\
MG & 24.51 & 17.37 & 27.51 & 3559. \\
MH & 22.83 & 14.64 & 17.79 & 3282. \\
MJ & 13.64 & 12.63 & 14.55 & 2402. \\
MK & 14.89 & 11.96 & 14.49 & 2055. \\
MM & 15.10 & 13.68 & 14.70 & 2728. \\
MN & 15.04 & 14.85 & 16.15 & 2620. \\
MP & 16.35 & 15.50 & 17.61 & 2890. \\
MR & 18.00 & 15.70 & 16.43 & 2871. \\
MS & 17.21 & 17.21 & 18.17 & 2851. \\
MT & 19.58 & 18.10 & 17.16 & 2626. \\
MU & 11.48 & 15.61 & 16.94 & 3209.
\end{tabular}


Table A4 (Continued)

\begin{tabular}{ccccc} 
Sample & \multicolumn{3}{l}{ Effective Porosity (8) } & Pore Area \\
ID & smal1 & medium large & $\left(\mathrm{m}^{2} / \mathrm{kg}\right)$ \\
Z1 PB & 19.84 & 12.80 & 18.31 & \\
PC & 20.27 & 13.30 & 17.94 & 3691. \\
PD & 18.55 & 15.70 & 22.56 & 3765. \\
PE & 17.40 & 11.61 & 15.49 & 4015. \\
PF & 15.64 & 11.50 & 15.29 & 2599. \\
PG & 16.06 & 11.68 & 17.23 & 2491. \\
PH & 19.56 & 14.75 & 15.74 & 2592. \\
& & & & \\
Z2 SB & 17.14 & 13.80 & 17.57 & 3603. \\
SC & 15.67 & 12.50 & 16.58 & 3010. \\
SD & 18.03 & 12.70 & 16.87 & 2832. \\
SE & 16.25 & 14.51 & 16.93 & 3572. \\
SF & 17.30 & 16.92 & 20.84 & 3147. \\
SG & 14.88 & 12.27 & 25.77 & 3697. \\
SH & 15.39 & 14.12 & 17.44 & 3241. \\
SJ & 15.57 & 13.95 & 16.11 & 2603. \\
SK & 17.10 & 12.81 & 14.55 & 2430. \\
SM & 14.71 & 13.24 & 14.77 & 2606. \\
SN & 19.30 & 47.58 & 14.98 & 2627. \\
SP & 17.84 & 18.47 & 17.54 & 2148. \\
& & & & \\
Z3 UW & 13.73 & 12.50 & 16.12 & 3293. \\
UC & 14.48 & 14.08 & 16.80 & 3207. \\
UD & 13.70 & 15.07 & 18.82 & 2916. \\
UE & 16.37 & 9.18 & 17.41 & 2407. \\
UF & 16.71 & 14.53 & 16.53 & 3133. \\
UG & 17.72 & 15.18 & 19.40 & 2858. \\
UH & 17.14 & 11.77 & 19.41 & 3009. \\
UJ & 19.83 & 13.12 & 14.98 & 2938. \\
UK & 16.52 & 12.13 & 14.94 & 2389. \\
UM & 15.38 & 14.83 & 15.71 & 2181. \\
UN & 15.97 & 15.19 & 15.31 & 2483. \\
UP & 14.29 & 11.16 & 14.82 & 1960. \\
UR & 17.66 & 15.50 & 17.45 & 2679. \\
US & 24.27 & 16.65 & 16.47 & 2686. \\
UT & 15.81 & 16.99 & 16.90 & 2924. \\
UU & 16.14 & 14.32 & 16.53 & 3181.
\end{tabular}


Table A5a: Equivalent pore diameters (in micrometers) for mercury intrusion injection pressures assuming a surface tension of $0.485 \mathrm{~Pa} \mathrm{~m}$, and a wetting angle of $130^{\circ}$. Table is for use in evaluating Table A5b.

ID Pore Diameter (micrometers) for Data in Table A5b

\begin{tabular}{|c|c|c|c|c|c|c|c|c|}
\hline $\mathrm{AA}$ & $\begin{array}{l}14.0 \\
2.05 \\
0.306 \\
0.0430\end{array}$ & $\begin{array}{l}9.19 \\
1.66 \\
0.236 \\
0.0337\end{array}$ & $\begin{array}{l}7.64 \\
1.27 \\
0.186 \\
0.0263\end{array}$ & $\begin{array}{l}6.31 \\
1.02 \\
0.146 \\
0.0205\end{array}$ & $\begin{array}{l}4.94 \\
0.80 \\
0.115 \\
0.0161\end{array}$ & $\begin{array}{l}4.05 \\
0.619 \\
0.0896 \\
0.0125\end{array}$ & $\begin{array}{l}3.26 \\
0.497 \\
0.0699 \\
0.0098\end{array}$ & $\begin{array}{l}2.61 \\
0.384 \\
0.0548 \\
0.0077\end{array}$ \\
\hline & $\begin{array}{l}14.0 \\
2.08 \\
0.303 \\
0.0430\end{array}$ & $\begin{array}{l}9.19 \\
1.64 \\
0.238 \\
0.0337\end{array}$ & $\begin{array}{l}7.64 \\
1.30 \\
0.187 \\
0.0262\end{array}$ & $\begin{array}{l}6.10 \\
1.01 \\
0.147 \\
0.0205\end{array}$ & $\begin{array}{l}5.09 \\
0.808 \\
0.115 \\
0.0161\end{array}$ & $\begin{array}{l}4.07 \\
0.633 \\
0.0896 \\
0.0125\end{array}$ & $\begin{array}{l}3.21 \\
0.493 \\
0.0701 \\
0.0098\end{array}$ & $\begin{array}{l}2.61 \\
0.389 \\
0.0550 \\
0.0077\end{array}$ \\
\hline
\end{tabular}

$\begin{array}{lllllllll}\text { AC } & 14.0 & 9.30 & 7.41 & 6.37 & 5.13 & 4.01 & 3.29 & 2.63\end{array}$

$\begin{array}{llllllll}2.08 & 1.65 & 1.30 & 1.03 & 0.809 & 0.627 & 0.491 & 0.384\end{array}$

$\begin{array}{lllllllll}0.303 & 0.238 & 0.186 & 0.147 & 0.115 & 0.0896 & 0.0701 & 0.0550\end{array}$

$\begin{array}{llllllllll}0.0430 & 0.0337 & 0.0262 & 0.0205 & 0.0161 & 0.0125 & 0.0098 & 0.0077\end{array}$

$\begin{array}{lllllllll}\mathrm{AD} & 13.8 & 9.30 & 7.71 & 6.36 & 4.96 & 4.07 & 3.26 & 2.61\end{array}$

$\begin{array}{llllllll}2.00 & 1.66 & 1.29 & 1.02 & 0.80 & 0.626 & 0.498 & 0.389\end{array}$

$\begin{array}{lllllllll}0.306 & 0.238 & 0.187 & 0.147 & 0.115 & 0.0899 & 0.0701 & 0.0548\end{array}$

$\begin{array}{llllllll}0.0429 & 0.0336 & 0.0262 & 0.0262 & 0.0161 & 0.0125 & 0.0098 & 0.0077\end{array}$

$\begin{array}{lllllllll}\mathrm{AE} & 13.8 & 9.30 & 7.72 & 6.37 & 5.12 & 4.09 & 3.29 & 2.59\end{array}$

$\begin{array}{llllllll}2.06 & 1.59 & 1.28 & 1.03 & 0.802 & 0.629 & 0.499 & 0.385\end{array}$

$\begin{array}{llllllll}0.305 & 0.238 & 0.188 & 0.147 & 0.115 & 0.0899 & 0.0703 & 0.0550\end{array}$

$\begin{array}{lllllllll}0.0430 & 0.0337 & 0.0263 & 0.0205 & 0.0161 & 0.0125 & 0.0098 & 0.0077\end{array}$

$\begin{array}{lllllllll}\mathrm{AF} & 13.8 & 9.30 & 7.40 & 6.36 & 5.11 & 4.09 & 3.29 & 2.62\end{array}$

$\begin{array}{llllllll}2.08 & 1.66 & 1.30 & 1.03 & 0.802 & 0.623 & 0.494 & 0.386\end{array}$

$\begin{array}{lllllllll}0.306 & 0.240 & 0.187 & 0.147 & 0.115 & 0.0899 & 0.0703 & 0.0550\end{array}$

$\begin{array}{llllllll}0.0430 & 0.0337 & 0.0263 & 0.0205 & 0.0160 & 0.0125 & 0.0098 & 0.0077\end{array}$

$\begin{array}{lllllllll}\text { AG } & 14.0 & 9.30 & 7.71 & 6.36 & 5.11 & 4.08 & 3.22 & 2.62\end{array}$

$\begin{array}{llllllll}2.08 & 1.65 & 1.30 & 1.03 & 0.795 & 0.629 & 0.495 & 0.387\end{array}$

$\begin{array}{llllllll}0.306 & 0.238 & 0.187 & 0.147 & 0.115 & 0.0896 & 0.0704 & 0.0550\end{array}$

$\begin{array}{llllllll}0.0430 & 0.0337 & 0.0262 & 0.0205 & 0.0160 & 0.0125 & 0.0098 & 0.0077\end{array}$

$\begin{array}{llllllllll}\mathrm{X} 2 & \mathrm{CA} & 14.0 & 8.85 & 7.46 & 6.41 & 5.15 & 4.11 & 3.24 & 2.63\end{array}$

$\begin{array}{llllllll}2.06 & 1.66 & 1.29 & 1.03 & 0.805 & 0.631 & 0.497 & 0.389\end{array}$

$\begin{array}{lllllllll}0.303 & 0.239 & 0.187 & 0.146 & 0.115 & 0.0896 & 0.0701 & 0.0544\end{array}$

$\begin{array}{lllllllll}0.0430 & 0.0337 & 0.0263 & 0.0205 & 0.0161 & 0.0125 & 0.0098 & 0.0077\end{array}$

$\begin{array}{lllllllll}\mathrm{CB} & 14.2 & 9.30 & 7.40 & 6.36 & 5.11 & 4.00 & 3.22 & 2.62\end{array}$

$\begin{array}{llllllll}2.08 & 1.66 & 1.29 & 1.02 & 0.797 & 0.628 & 0.499 & 0.383\end{array}$

$\begin{array}{lllllllll}0.295 & 0.237 & 0.188 & 0.146 & 0.115 & 0.0899 & 0.0701 & 0.0548\end{array}$

$\begin{array}{lllllllll}0.0430 & 0.0336 & 0.0262 & 0.0205 & 0.0161 & 0.0125 & 0.0098 & 0.0077\end{array}$ 
$\mathrm{CC}$

$\begin{array}{llllllll}14.1 & 9.30 & 7.71 & 6.36 & 4.97 & 4.08 & 3.27 & 2.58 \\ 2.05 & 1.64 & 1.25 & 1.02 & 0.808 & 0.595 & 0.494 & 0.387 \\ 0.300 & 0.238 & 0.186 & 0.146 & 0.115 & 0.0896 & 0.0701 & 0.0550 \\ 0.0429 & 0.0336 & 0.0262 & 0.0205 & 0.0161 & 0.0125 & 0.0098 & 0.0077\end{array}$

$\begin{array}{lllllllll}\mathrm{CD} & 13.7 & 9.30 & 7.72 & 6.37 & 5.12 & 4.10 & 3.23 & 2.59\end{array}$

$\begin{array}{llllllll}2.08 & 1.65 & 1.30 & 1.02 & 0.791 & 0.633 & 0.487 & 0.384\end{array}$

$\begin{array}{lllllllll}0.302 & 0.239 & 0.188 & 0.144 & 0.114 & 0.0899 & 0.0701 & 0.0550\end{array}$

$\begin{array}{lllllllll}0.0430 & 0.0337 & 0.0263 & 0.0205 & 0.0161 & 0.0125 & 0.0098 & 0.0077\end{array}$

\begin{tabular}{|c|c|c|c|c|c|c|}
\hline $\begin{array}{l}13.9 \\
2.09 \\
0.306 \\
0.0430\end{array}$ & $\begin{array}{l}9.30 \\
1.67 \\
0.24 \\
0.0336\end{array}$ & $\begin{array}{l}7.72 \\
1.30 \\
0.187 \\
0.0262\end{array}$ & $\begin{array}{l}6.37 \\
1.03 \\
0.147 \\
0.0205\end{array}$ & $\begin{array}{l}5.13 \\
0.786 \\
0.115 \\
0.0161\end{array}$ & $\begin{array}{l}4.11 \\
0.634 \\
0.09 \\
0.0125\end{array}$ & $\begin{array}{ll}3.30 & 2.64 \\
0.498 & 0.387 \\
0.0701 & 0.0550 \\
0.0098 & 0.0077\end{array}$ \\
\hline
\end{tabular}

$\begin{array}{cllllllll}\text { CF } & 13.7 & 9.30 & 7.71 & 6.36 & 5.12 & 4.10 & 3.29 & 2.63 \\ & 2.09 & 1.67 & 1.31 & 1.02 & 0.799 & 0.621 & 0.498 & 0.383 \\ & 0.305 & 0.238 & 0.187 & 0.145 & 0.115 & 0.0896 & 0.0703 & 0.0550 \\ & 0.0430 & 0.0336 & 0.0263 & 0.0205 & 0.0161 & 0.0125 & 0.0098 & 0.0077\end{array}$

\begin{tabular}{|c|c|c|c|c|c|c|c|}
\hline $\begin{array}{l}13.8 \\
2.10 \\
0.302 \\
0.0430\end{array}$ & $\begin{array}{l}9.30 \\
1.64 \\
0.238 \\
0.0337\end{array}$ & $\begin{array}{l}7.72 \\
1.31 \\
0.187 \\
0.0263\end{array}$ & $\begin{array}{l}6.38 \\
1.03 \\
0.146 \\
0.0205\end{array}$ & $\begin{array}{l}5.15 \\
0.804 \\
0.115 \\
0.0161\end{array}$ & $\begin{array}{l}4.12 \\
0.633 \\
0.09 \\
0.0125\end{array}$ & $\begin{array}{l}3.25 \\
0.499 \\
0.0704 \\
0.0099\end{array}$ & $\begin{array}{l}2.60 \\
0.388 \\
0.0550 \\
0.0077\end{array}$ \\
\hline
\end{tabular}

$\begin{array}{lllllllll}\mathrm{CH} & 13.7 & \mathbf{8 . 8 5} & 7.72 & 6.38 & 5.14 & 4.02 & 3.24 & 2.63\end{array}$

$\begin{array}{lllllllll}2.09 & 1.67 & 1.31 & 1.03 & 0.8110 & 0.6260 & 0.498 & 0.386\end{array}$

$\begin{array}{lllllllll}0.299 & 0.238 & 0.186 & 0.147 & 0.115 & 0.0896 & 0.0701 & 0.0548\end{array}$

$\begin{array}{llllllll}0.0430 & 0.0337 & 0.0263 & 0.0205 & 0.0161 & 0.0125 & 0.0098 & 0.0077\end{array}$

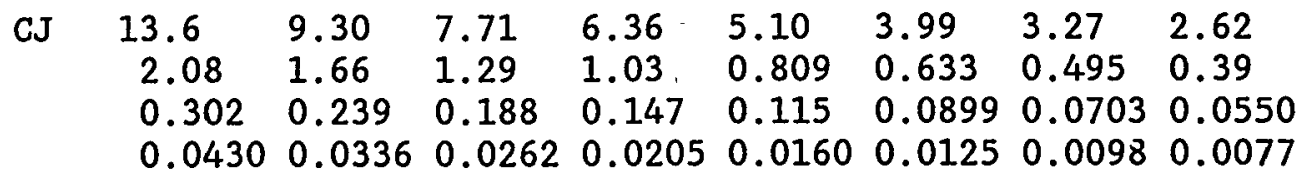

$\begin{array}{lllllllll}\mathrm{CK} & 13.8 & 9.30 & 7.71 & 6.36 & 5.11 & 3.99 & 3.29 & 2.59\end{array}$ $\begin{array}{llllllll}2.09 & 1.67 & 1.30 & 1.03 & 0.811 & 0.635 & 0.492 & 0.384\end{array}$

$\begin{array}{llllllll}0.303 & 0.239 & 0.188 & 0.147 & 0.115 & 0.09 & 0.0701 & 0.0550\end{array}$ $\begin{array}{llllllll}0.0430 & 0.0337 & 0.0263 & 0.0205 & 0.0161 & 0.0125 & 0.0098 & 0.0077\end{array}$

$\begin{array}{lllllllll}\text { CM } & 13.8 & 9.30 & 7.71 & 5.94 & 5.11 & 4.09 & 3.23 & 2.59\end{array}$

$\begin{array}{rrrrrrrr}2.09 & 1.67 & 1.31 & 1.03 & 0.806 & 0.625 & 0.49 & 0.385\end{array}$

$\begin{array}{llllllll}0.304 & 0.237 & 0.188 & 0.147 & 0.115 & 0.0899 & 0.0703 & 0.0550\end{array}$ $\begin{array}{lllllllll}0.0430 & 0.0336 & 0.0263 & 0.0206 & 0.0161 & 0.0125 & 0.0098 & 0.0077\end{array}$

\begin{tabular}{|c|c|c|c|c|c|c|c|}
\hline $\begin{array}{l}13.9 \\
2.09 \\
0.306 \\
0.0430\end{array}$ & $\begin{array}{l}9.30 \\
1.65 \\
0.237 \\
0.0336\end{array}$ & $\begin{array}{l}7.71 \\
1.31 \\
0.188 \\
0.0263\end{array}$ & $\begin{array}{l}6.36 \\
1.03 \\
0.146 \\
0.0205\end{array}$ & $\begin{array}{l}4.96 \\
0.807 \\
0.114 \\
0.0160\end{array}$ & $\begin{array}{l}4.07 \\
0.632 \\
0.09 \\
0.0125\end{array}$ & $\begin{array}{l}3.26 \\
0.50 \\
0.0704 \\
0.0098\end{array}$ & $\begin{array}{l}2.61 \\
0.382 \\
0.0550 \\
0.0077\end{array}$ \\
\hline
\end{tabular}


Table A5a (Continued)

ID Pore Diameter (micrometers) for Data in Table A5b

\begin{tabular}{|c|c|c|c|c|c|c|c|c|}
\hline EA & $\begin{array}{l}14.1 \\
2.08 \\
0.30 \\
0.0430\end{array}$ & $\begin{array}{l}9.30 \\
1.66 \\
0.239 \\
0.0337\end{array}$ & $\begin{array}{l}7.40 \\
1.29 \\
0.188 \\
0.0263\end{array}$ & $\begin{array}{l}6.37 \\
1.03 \\
0.147 \\
0.0205\end{array}$ & $\begin{array}{l}5.11 \\
0.808 \\
0.115 \\
0.0161\end{array}$ & $\begin{array}{l}4.08 \\
0.626 \\
0.0896 \\
0.0125\end{array}$ & $\begin{array}{l}3.27 \\
0.499 \\
0.0703 \\
0.0098\end{array}$ & $\begin{array}{l}2.62 \\
0.386 \\
0.0548 \\
0.0077\end{array}$ \\
\hline
\end{tabular}

$\begin{array}{lllllllll}\text { EB } & 13.7 & 8.84 & 7.71 & 6.36 & 4.97 & 4.07 & 3.27 & 2.61\end{array}$

$\begin{array}{llllllll}2.07 & 1.66 & 1.28 & 1.03 & 0.804 & 0.633 & 0.496 & 0.385\end{array}$

$\begin{array}{lllllllll}0.306 & 0.238 & 0.188 & 0.147 & 0.115 & 0.0896 & 0.0703 & 0.0548\end{array}$

$\begin{array}{lllllllll}0.0430 & 0.0337 & 0.0262 & 0.0205 & 0.0161 & 0.0125 & 0.0098 & 0.0077\end{array}$

$\begin{array}{lllllllll}\text { EC } & 13.9 & 9.30 & 7.72 & 6.38 & 5.13 & 4.01 & 3.30 & 2.59\end{array}$

$\begin{array}{llllllll}2.09 & 1.65 & 1.31 & 1.03 & 0.81 & 0.634 & 0.497 & 0.386\end{array}$

$\begin{array}{llllllll}0.303 & 0.238 & 0.187 & 0.146 & 0.115 & 0.09 & 0.0704 & 0.0550\end{array}$

$\begin{array}{llllllll}0.0430 & 0.0337 & 0.0263 & 0.0205 & 0.0160 & 0.0125 & 0.0098\end{array}$

$\begin{array}{lllllllll}\text { ED } & 13.7 & 9.30 & 7.71 & 6.37 & 5.12 & 4.09 & 3.28 & 2.58\end{array}$

$\begin{array}{llllllll}2.08 & 1.66 & 1.27 & 1.03 & 0.801 & 0.631 & 0.497 & 0.382\end{array}$

$\begin{array}{lllllllll}0.302 & 0.239 & 0.187 & 0.146 & 0.115 & 0.0899 & 0.0703 & 0.0550\end{array}$

$\begin{array}{lllllllll}0.0430 & 0.0337 & 0.0263 & 0.0206 & 0.0161 & 0.0125 & 0.0098 & 0.0077\end{array}$

$\begin{array}{lllllllll}\text { EE } & 14.0 & 9.30 & 7.72 & 5.94 & 5.13 & 4.10 & 3.29 & 2.63\end{array}$

$\begin{array}{llllllll}2.06 & 1.67 & 1.31 & 1.02 & 0.809 & 0.625 & 0.491 & 0.388\end{array}$

$\begin{array}{lllllllll}0.306 & 0.239 & 0.187 & 0.147 & 0.115 & 0.0899 & 0.0704 & 0.0550\end{array}$

$\begin{array}{lllllllll}0.0430 & 0.0337 & 0.0263 & 0.0206 & 0.0161 & 0.0125 & 0.0098 & 0.0077\end{array}$

$\begin{array}{lllllllll}\mathrm{EF} & 13.8 & 9.30 & 7.72 & 6.37 & 5.13 & 4.10 & 3.23 & 2.62\end{array}$

$\begin{array}{llllllll}2.08 & 1.66 & 1.28 & 1.03 & 0.801 & 0.633 & 0.499 & 0.385\end{array}$

$\begin{array}{llllllll}0.302 & 0.238 & 0.187 & 0.147 & 0.115 & 0.0899 & 0.0703 & 0.0550\end{array}$

$\begin{array}{lllllllll}0.0430 & 0.0337 & 0.0262 & 0.0205 & 0.0161 & 0.0125 & 0.0098 & 0.0077\end{array}$

EG $\quad \begin{array}{llllllll}14.0 & 9.30 & 7.71 & 6.14 & 5.10 & 4.08 & 3.28 & 2.62\end{array}$

$\begin{array}{llllllll}2.08 & 1.66 & 1.29 & 1.03 & 0.805 & 0.629 & 0.476 & 0.388\end{array}$

$\begin{array}{llllllll}0.302 & 0.236 & 0.186 & 0.147 & 0.114 & 0.0899 & 0.0703 & 0.0550\end{array}$

$\begin{array}{lllllllllll}0.0430 & 0.0337 & 0.0263 & 0.0205 & 0.0161 & 0.0124 & 0.0098 & 0.0077\end{array}$

$\begin{array}{lllllllll}\text { EH } & 13.8 & 8.85 & 7.71 & 6.36 & 5.11 & 4.08 & 3.28 & 2.63\end{array}$

$\begin{array}{llllllll}2.09 & 1.65 & 1.31 & 1.03 & 0.809 & 0.625 & 0.494 & 0.389\end{array}$

$\begin{array}{lllllllll}0.3 & 0.237 & 0.186 & 0.146 & 0.114 & 0.0899 & 0.0701 & 0.0550\end{array}$

$\begin{array}{lllllllll}0.0430 & 0.0337 & 0.0262 & 0.0205 & 0.0161 & 0.0125 & 0.0098 & 0.0077\end{array}$

$\begin{array}{lllllllll}\text { EJ } & 13.9 & 9.30 & 7.40 & 6.36 & 5.11 & 4.08 & 3.28 & 2.62\end{array}$

$\begin{array}{llllllll}2.09 & 1.67 & 1.31 & 1.03 & 0.806 & 0.632 & 0.491 & 0.389\end{array}$

$\begin{array}{llllllll}0.304 & 0.24 & 0.187 & 0.147 & 0.115 & 0.0899 & 0.0701 & 0.0550\end{array}$

$\begin{array}{lllllllll}0.0430 & 0.0337 & 0.0263 & 0.0205 & 0.0160 & 0.0125 & 0.0098 & 0.0077\end{array}$

$\begin{array}{lllllllll}\text { EK } & 13.7 & 9.30 & 7.71 & 6.14 & 4.96 & 4.08 & 3.21 & 2.62\end{array}$

$\begin{array}{llllllll}2.08 & 1.66 & 1.30 & 1.03 & 0.809 & 0.634 & 0.494 & 0.389\end{array}$

$\begin{array}{lllllllll}0.305 & 0.238 & 0.187 & 0.147 & 0.115 & 0.0896 & 0.0701 & 0.0548\end{array}$

$\begin{array}{lllllllll}0.0430 & 0.0336 & 0.0263 & 0.0205 & 0.0160 & 0.0125 & 0.0098 & 0.0077\end{array}$ 
Table A5a (Continued)

ID Pore Diameter (micrometers) for Data in Table A5b

EM $\begin{array}{lllllllll}13.9 & 9.30 & 7.71 & 6.36 & 5.11 & 4.08 & 3.28 & 2.58 \\ & 2.08 & 1.66 & 1.31 & 1.02 & 0.799 & 0.632 & 0.498 & 0.386 \\ & 0.306 & 0.239 & 0.187 & 0.146 & 0.115 & 0.0899 & 0.0701 & 0.0550 \\ & 0.0429 & 0.0337 & 0.0263 & 0.0206 & 0.0161 & 0.0125 & 0.0098 & 0.0077\end{array}$

$\begin{array}{lllllllll}\text { EN } & 13.8 & 9.30 & 7.71 & 6.36 & 5.11 & 4.08 & 3.28 & 2.62\end{array}$

$\begin{array}{rlllllll}2.06 & 1.67 & 1.31 & 1.03 & 0.81 & 0.634 & 0.486 & 0.386\end{array}$

$\begin{array}{lllllllll}0.303 & 0.239 & 0.187 & 0.147 & 0.115 & 0.0899 & 0.0701 & 0.0550\end{array}$

$\begin{array}{lllllllll}0.0430 & 0.0336 & 0.0263 & 0.0205 & 0.0161 & 0.0125 & 0.0098 & 0.0077\end{array}$

$\begin{array}{lllllllll}\mathrm{EP} & 13.9 & 9.30 & 7.71 & 6.36 & 5.11 & 4.07 & 3.27 & 2.62\end{array}$

$\begin{array}{llllllll}2.09 & 1.67 & 1.31 & 1.03 & 0.803 & 0.634 & 0.498 & 0.388\end{array}$

$\begin{array}{lllllllll}0.306 & 0.238 & 0.187 & 0.146 & 0.115 & 0.0899 & 0.0701 & 0.0550\end{array}$

$\begin{array}{lllllllll}0.0430 & 0.0337 & 0.0262 & 0.0205 & 0.0161 & 0.0125 & 0.0098 & 0.0077\end{array}$

$\begin{array}{lllllllll}\text { ER } & 13.8 & 9.30 & 7.40 & 6.36 & 5.10 & 3.99 & 3.27 & 2.62\end{array}$

$\begin{array}{llllllll}2.08 & 1.66 & 1.30 & 1.03 & 0.806 & 0.632 & 0.499 & 0.387\end{array}$

$\begin{array}{llllllll}0.304 & 0.238 & 0.187 & 0.147 & 0.115 & 0.0899 & 0.0701 & 0.0550\end{array}$

$\begin{array}{lllllllll}0.0430 & 0.0337 & 0.0262 & 0.0205 & 0.0161 & 0.0125 & 0.0098\end{array}$

$\begin{array}{lllllllll}\text { ES } & 13.8 & 9.30 & 7.40 & 6.36 & 4.96 & 4.07 & 3.27 & 2.61\end{array}$

$\begin{array}{llllllll}2.08 & 1.65 & 1.30 & 1.02 & 0.802 & 0.633 & 0.498 & 0.384\end{array}$

$\begin{array}{lllllllll}0.302 & 0.239 & 0.185 & 0.147 & 0.115 & 0.0896 & 0.0703 & 0.0550\end{array}$

$\begin{array}{lllllllll}0.0430 & 0.0337 & 0.0263 & 0.0205 & 0.0161 & 0.0125 & 0.0098 & 0.0077\end{array}$

$\begin{array}{lllllllll}\text { ET } & 13.7 & 8.84 & 7.40 & 6.14 & 5.10 & 4.08 & 3.27 & 2.58\end{array}$

$\begin{array}{rrrrrrrr}2.08 & 1.66 & 1.30 & 1.03 & 0.809 & 0.625 & 0.492 & 0.385\end{array}$

$\begin{array}{llllllll}0.303 & 0.237 & 0.186 & 0.146 & 0.115 & 0.0899 & 0.0703 & 0.0548\end{array}$

$\begin{array}{lllllllll}0.0430 & 0.0337 & 0.0263 & 0.0205 & 0.0161 & 0.0125 & 0.0098 & 0.0077\end{array}$

\begin{tabular}{|c|c|c|c|c|c|c|c|c|}
\hline $\mathrm{GB}$ & $\begin{array}{c}14.2 \\
2.06 \\
0.302 \\
0.0430\end{array}$ & $\begin{array}{l}9.30 \\
1.66 \\
0.237 \\
0.0337\end{array}$ & $\begin{array}{l}7.71 \\
1.30 \\
0.187 \\
0.0263\end{array}$ & $\begin{array}{l}6.36 \\
1.03 \\
0.146 \\
0.0205\end{array}$ & $\begin{array}{l}5.11 \\
0.792 \\
0.115 \\
0.0161\end{array}$ & $\begin{array}{l}4.09 \\
0.634 \\
0.0896 \\
0.0125\end{array}$ & $\begin{array}{l}3.29 \\
0.498 \\
0.0704 \\
0.0098\end{array}$ & $\begin{array}{l}2.63 \\
0.383 \\
0.0548 \\
0.0077\end{array}$ \\
\hline GC & $\begin{array}{l}13.9 \\
2.08 \\
0.301 \\
0.0430\end{array}$ & $\begin{array}{l}9.30 \\
1.66 \\
0.239 \\
0.0336\end{array}$ & $\begin{array}{l}7.71 \\
1.30 \\
0.186 \\
0.0263\end{array}$ & $\begin{array}{l}6.14 \\
1.03 \\
0.147 \\
0.0205\end{array}$ & $\begin{array}{l}4.97 \\
0.805 \\
0.115 \\
0.0161\end{array}$ & $\begin{array}{l}4.08 \\
0.633 \\
0.0899 \\
0.0125\end{array}$ & $\begin{array}{l}3.28 \\
0.493 \\
0.0701 \\
0.0098\end{array}$ & $\begin{array}{l}2.62 \\
0.385 \\
0.0547 \\
0.0077\end{array}$ \\
\hline GD & $\begin{array}{l}- \\
2.08 \\
0.306 \\
0.0430\end{array}$ & $\begin{array}{l}9.30 \\
1.66 \\
0.234 \\
0.0337\end{array}$ & $\begin{array}{l}7.71 \\
1.27 \\
0.187 \\
0.0263\end{array}$ & $\begin{array}{l}6.36 \\
1.03 \\
0.147 \\
0.0205\end{array}$ & $\begin{array}{l}5.11 \\
0.808 \\
0.115 \\
0.0161\end{array}$ & $\begin{array}{l}4.08 \\
0.631 \\
0.0896 \\
0.0125\end{array}$ & $\begin{array}{l}3.27 \\
0.491 \\
0.0703 \\
0.0098\end{array}$ & $\begin{array}{l}2.62 \\
0.389 \\
0.0550 \\
0.0077\end{array}$ \\
\hline GA & $\begin{array}{l}13.6 \\
2.08 \\
0.301 \\
0.0430\end{array}$ & $\begin{array}{l}9.30 \\
1.66 \\
0.239 \\
0.0336\end{array}$ & $\begin{array}{l}7.72 \\
1.30 \\
0.187 \\
0.0262\end{array}$ & $\begin{array}{l}6.37 \\
1.03 \\
0.146 \\
0.0205\end{array}$ & $\begin{array}{l}5.13 \\
0.801 \\
0.115 \\
0.0161\end{array}$ & $\begin{array}{l}4.10 \\
0.629 \\
0.0896 \\
0.0125\end{array}$ & $\begin{array}{l}3.29 \\
0.499 \\
0.0701 \\
0.0098\end{array}$ & $\begin{array}{l}2.62 \\
0.386 \\
0.0550 \\
0.0077\end{array}$ \\
\hline
\end{tabular}


Table A5a (Continued)

ID Pore Diameter (micrometers) for Data in Table A5b

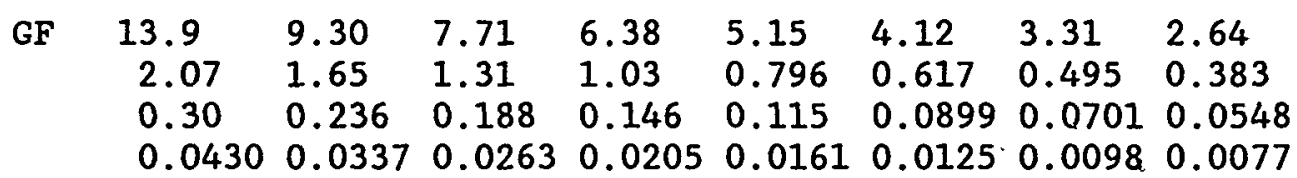

GG $\quad \begin{array}{lllllllll}13.8 & 9.30 & 7.40 & 6.36 & 5.12 & 4.10 & 3.29 & 2.59\end{array}$

$\begin{array}{llllllll}2.06 & 1.67 & 1.31 & 1.03 & 0.807 & 0.634 & 0.498 & 0.386\end{array}$

$\begin{array}{lllllllll}0.297 & 0.237 & 0.186 & 0.146 & 0.113 & 0.0899 & 0.0704 & 0.0547\end{array}$

$\begin{array}{lllllllll}0.0430 & 0.0336 & 0.0263 & 0.0205 & 0.0161 & 0.0125 & 0.0098 & 0.0077\end{array}$

$\begin{array}{lllllllll}\mathrm{GH} & 13.8 & 9.30 & 7.71 & 6.14 & 4.97 & 4.09 & 3.29 & 2.62\end{array}$

$\begin{array}{llllllll}2.08 & 1.66 & 1.30 & 1.03 & 0.807 & 0.623 & 0.50 & 0.39\end{array}$

$\begin{array}{lllllllll}0.306 & 0.238 & 0.187 & 0.146 & 0.115 & 0.0896 & 0.0701 & 0.0547\end{array}$

$\begin{array}{lllllllll}0.0430 & 0.0337 & 0.0262 & 0.0206 & 0.0161 & 0.0125 & 0.0098 & 0.0077\end{array}$

$\begin{array}{llllllllll}\mathrm{Y} 2 & \mathrm{JB} & 13.7 & 8.85 & 7.40 & 6.15 & 5.13 & 4.10 & 3.28 & 2.59\end{array}$

$\begin{array}{llllllll}2.06 & 1.66 & 1.30 & 1.03 & 0.791 & 0.61 & 0.488 & 0.384\end{array}$

$\begin{array}{lllllllll}0.304 & 0.239 & 0.188 & 0.147 & 0.114 & 0.0896 & 0.0704 & 0.0548\end{array}$

$\begin{array}{lllllllll}0.0430 & 0.0337 & 0.0263 & 0.0205 & 0.0161 & 0.0125 & 0.0098 & 0.0077\end{array}$

$\begin{array}{lllllllll}\text { JC } & 13.8 & 9.30 & 7.40 & 6.36 & 5.10 & 4.07 & 3.21 & 2.43\end{array}$

$\begin{array}{llllllll}2.07 & 1.65 & 1.30 & 1.03 & 0.807 & 0.632 & 0.487 & 0.386\end{array}$

$\begin{array}{llllllllll}0.3050 & 0.2380 & 0.1870 & 0.1470 & 0.1150 & 0.0892 & 0.0701 & 0.0550\end{array}$

$\begin{array}{lllllllll}0.0429 & 0.0336 & 0.0263 & 0.0205 & 0.0161 & 0.0125 & 0.0098 & 0.0077\end{array}$

$\begin{array}{lllllllll}\text { JD } & 13.9 & 9.30 & 7.71 & 6.36 & 5.10 & 4.07 & 3.21 & 2.61\end{array}$

$\begin{array}{llllllll}2.07 & 1.66 & 1.29 & 1.03 & 0.796 & 0.632 & 0.489 & 0.387\end{array}$

$\begin{array}{llllllll}0.306 & 0.239 & 0.187 & 0.147 & 0.115 & 0.0896 & 0.0703 & 0.0548\end{array}$

$\begin{array}{lllllllll}0.0430 & 0.0336 & 0.0263 & 0.0205 & 0.0161 & 0.0125 & 0.0098 & 0.0077\end{array}$

JE

$\begin{array}{llllllll}- & 9.30 & 7.71 & 6.36 & 5.10 & 4.07 & 3.20 & 2.60 \\ 2.07 & 1.64 & 1.30 & 1.03 & 0.782 & 0.617 & 0.498 & 0.386 \\ 0.302 & 0.238 & 0.188 & 0.147 & 0.115 & 0.0895 & 0.0703 & 0.0548 \\ 0.0430 & 0.0336 & 0.0263 & 0.0206 & 0.0161 & 0.0125 & 0.0098 & 0.0077\end{array}$

$\begin{array}{lllllllll}\mathrm{JF} & 13.8 & 9.30 & 7.74 & 6.40 & 5.16 & 4.03 & 3.30 & 2.64\end{array}$

$\begin{array}{llllllll}2.07 & 1.67 & 1.31 & 1.03 & 0.796 & 0.634 & 0.498 & 0.388\end{array}$

$\begin{array}{lllllllll}0.306 & 0.238 & 0.187 & 0.147 & 0.115 & 0.0896 & 0.0704 & 0.0548\end{array}$

$\begin{array}{llllllllll}0.0430 & 0.0336 & 0.0263 & 0.0205 & 0.0160 & 0.0125 & 0.0098 & 0.0077\end{array}$

$\begin{array}{lllllllll}\text { JG } & 13.7 & 9.30 & 7.71 & 6.37 & 5.12 & 4.10 & 3.28 & 2.62\end{array}$

$\begin{array}{llllllll}2.08 & 1.66 & 1.29 & 1.02 & 0.805 & 0.618 & 0.492 & 0.386\end{array}$

$\begin{array}{lllllllll}0.301 & 0.237 & 0.186 & 0.146 & 0.114 & 0.0899 & 0.0703 & 0.0550\end{array}$

$\begin{array}{lllllllll}0.0430 & 0.0336 & 0.0262 & 0.0205 & 0.0161 & 0.0125 & 0.0098 & 0.0077\end{array}$

$\begin{array}{lllllllll}\mathrm{JH} & 13.8 & 9.30 & 7.71 & 6.36 & 5.12 & 4.10 & 3.29 & 2.63\end{array}$

$\begin{array}{llllllll}2.09 & 1.65 & 1.31 & 1.03 & 0.799 & 0.617 & 0.490 & 0.383\end{array}$

$\begin{array}{llllllll}0.303 & 0.237 & 0.187 & 0.146 & 0.115 & 0.0896 & 0.0704 & 0.0550\end{array}$

$\begin{array}{lllllllll}0.0430 & 0.0337 & 0.0263 & 0.0205 & 0.0161 & 0.0125 & 0.0098 & 0.0077\end{array}$ 
Table A5a (Continued)

ID Pore Diameter (micrometers) for Data in Table A5b

$$
\begin{array}{lllllllll}
\text { JJ } & 13.8 & 9.30 & 7.40 & 6.37 & 5.12 & 4.09 & 3.23 & 2.63 \\
& 2.08 & 1.65 & 1.30 & 1.03 & 0.809 & 0.633 & 0.488 & 0.389 \\
& 0.302 & 0.235 & 0.185 & 0.146 & 0.114 & 0.0896 & 0.0701 & 0.0550 \\
& 0.0430 & 0.0337 & 0.0263 & 0.0205 & 0.0160 & 0.0125 & 0.0098 & 0.0077
\end{array}
$$

\begin{tabular}{|c|c|c|c|c|c|c|c|c|}
\hline JM & $\begin{array}{c}13.7 \\
2.09 \\
0.301 \\
0.0430\end{array}$ & $\begin{array}{l}9.30 \\
1.67 \\
0.237 \\
0.0337\end{array}$ & $\begin{array}{l}7.71 \\
1.31 \\
0.186 \\
0.0263\end{array}$ & $\begin{array}{l}6.15 \\
1.03 \\
0.146 \\
0.0205\end{array}$ & $\begin{array}{l}4.98 \\
0.810 \\
0.115 \\
0.0161\end{array}$ & $\begin{array}{l}4.09 \\
0.617 \\
0.0899 \\
0.0125\end{array}$ & $\begin{array}{l}3.29 \\
0.497 \\
0.0704 \\
0.0098\end{array}$ & $\begin{array}{l}2.63 \\
0.381 \\
0.0550 \\
0.0077\end{array}$ \\
\hline $\mathrm{JN}$ & $\begin{array}{l}13.7 \\
2.09 \\
0.304 \\
0.0430\end{array}$ & $\begin{array}{l}8.84 \\
1.67 \\
0.239 \\
0.0337\end{array}$ & $\begin{array}{l}7.71 \\
1.31 \\
0.187 \\
0.0263\end{array}$ & $\begin{array}{l}6.14 \\
1.03 \\
0.146 \\
0.0205\end{array}$ & $\begin{array}{l}5.10 \\
0.810 \\
0.115 \\
0.0161\end{array}$ & $\begin{array}{l}4.07 \\
0.634 \\
0.0899 \\
0.0125\end{array}$ & $\begin{array}{l}3.28 \\
0.499 \\
0.0701 \\
0.0098\end{array}$ & $\begin{array}{l}2.62 \\
0.388 \\
0.0550 \\
0.0077\end{array}$ \\
\hline JP & $\begin{array}{l}13.7 \\
2.08 \\
0.298 \\
0.0429\end{array}$ & $\begin{array}{l}9.30 \\
1.66 \\
0.237 \\
0.0337\end{array}$ & $\begin{array}{l}7.72 \\
1.30 \\
0.186 \\
0.0262\end{array}$ & $\begin{array}{l}6.37 \\
1.03 \\
0.146 \\
0.0205\end{array}$ & $\begin{array}{l}4.97 \\
0.808 \\
0.115 \\
0.0161\end{array}$ & $\begin{array}{l}3.99 \\
0.633 \\
0.0896 \\
0.0125\end{array}$ & $\begin{array}{l}3.28 \\
0.499 \\
0.0703 \\
0.0098\end{array}$ & $\begin{array}{l}2.62 \\
0.386 \\
0.0550 \\
0.0077\end{array}$ \\
\hline MB & $\begin{array}{l}\quad- \\
2.07 \\
0.304 \\
0.0429\end{array}$ & $\begin{array}{l}9.30 \\
1.65 \\
0.236 \\
0.0337\end{array}$ & $\begin{array}{l}7.71 \\
1.30 \\
0.188 \\
0.0263\end{array}$ & $\begin{array}{l}6.36 \\
1.03 \\
0.145 \\
0.0205\end{array}$ & $\begin{array}{l}5.10 \\
0.803 \\
0.115 \\
0.0161\end{array}$ & $\begin{array}{l}4.07 \\
0.630 \\
0.0892 \\
0.0125\end{array}$ & $\begin{array}{l}3.15 \\
0.492 \\
0.0703 \\
0.0098\end{array}$ & $\begin{array}{l}2.60 \\
0.384 \\
0.0549 \\
0.0077\end{array}$ \\
\hline MC & $\begin{array}{l}14.0 \\
2.04 \\
0.3 \\
0.0430\end{array}$ & $\begin{array}{l}8.84 \\
1.64 \\
0.238 \\
0.0336\end{array}$ & $\begin{array}{l}7.71 \\
1.30 \\
0.186 \\
0.0262\end{array}$ & $\begin{array}{l}6.36 \\
1.03 \\
0.147 \\
0.0205\end{array}$ & $\begin{array}{l}5.10 \\
0.806 \\
0.115 \\
0.0161\end{array}$ & $\begin{array}{l}4.07 \\
0.623 \\
0.0899 \\
0.0125\end{array}$ & $\begin{array}{l}3.26 \\
0.495 \\
0.0703 \\
0.0098\end{array}$ & $\begin{array}{l}2.60 \\
0.381 \\
0.0549 \\
0.0077\end{array}$ \\
\hline $\mathbb{M}$ & $\begin{array}{c}14.0 \\
2.07 \\
0.304 \\
0.0430\end{array}$ & $\begin{array}{l}8.84 \\
1.65 \\
0.239 \\
0.0337\end{array}$ & $\begin{array}{l}7.71 \\
1.30 \\
0.188 \\
0.0263\end{array}$ & $\begin{array}{l}6.36 \\
1.03 \\
0.147 \\
0.0205\end{array}$ & $\begin{array}{l}5.10 \\
0.792 \\
0.115 \\
0.0161\end{array}$ & $\begin{array}{l}4.07 \\
0.630 \\
0.0896 \\
0.0125\end{array}$ & $\begin{array}{l}3.26 \\
0.498 \\
0.0703 \\
0.0098\end{array}$ & $\begin{array}{l}2.57 \\
0.389 \\
0.0548 \\
0.0077\end{array}$ \\
\hline$M$ & $\begin{array}{l}13.9 \\
2.06 \\
0.305 \\
0.0430\end{array}$ & $\begin{array}{l}9.30 \\
1.65 \\
0.238 \\
0.0337\end{array}$ & $\begin{array}{l}7.71 \\
1.30 \\
0.188 \\
0.0263\end{array}$ & $\begin{array}{l}6.36 \\
1.03 \\
0.147 \\
0.0205\end{array}$ & $\begin{array}{l}5.12 \\
0.809 \\
0.115 \\
0.0160\end{array}$ & $\begin{array}{l}4.10 \\
0.629 \\
0.0896 \\
0.0125\end{array}$ & $\begin{array}{l}3.23 \\
0.499 \\
0.0704 \\
0.0098\end{array}$ & $\begin{array}{l}2.62 \\
0.382 \\
0.0550 \\
0.0077\end{array}$ \\
\hline $\mathbf{M}$ & $\begin{array}{l}13.7 \\
2.08 \\
0.305 \\
0.043\end{array}$ & $\begin{array}{l}8.85 \\
1.66 \\
0.238 \\
0.0337\end{array}$ & $\begin{array}{l}7.72 \\
1.30 \\
0.187 \\
0.0263\end{array}$ & $\begin{array}{l}6.14 \\
1.03 \\
0.146 \\
0.0205\end{array}$ & $\begin{array}{l}5.11 \\
0.810 \\
0.115 \\
0.0161\end{array}$ & $\begin{array}{l}4.08 \\
0.632 \\
0.0896 \\
0.0125\end{array}$ & $\begin{array}{l}3.27 \\
0.499 \\
0.0704 \\
0.0098\end{array}$ & $\begin{array}{l}2.62 \\
0.386 \\
0.0550 \\
0.0077\end{array}$ \\
\hline
\end{tabular}

$\begin{array}{lllllllll}\text { JK } & 13.8 & 9.30 & 7.40 & 6.37 & 5.12 & 4.10 & 3.29 & 2.59 \\ & 2.09 & 1.67 & 1.30 & 1.03 & 0.810 & 0.619 & 0.490 & 0.382 \\ & 0.303 & 0.238 & 0.185 & 0.147 & 0.115 & 0.0899 & 0.0704 & 0.0550 \\ & 0.0430 & 0.0337 & 0.0263 & 0.0205 & 0.0161 & 0.0125 & 0.0098 & 0.0077\end{array}$


Table A5a (Continued)

ID Pore Diameter (micrometers) for Data in Table A5b

\begin{tabular}{|c|c|c|c|c|c|c|c|c|}
\hline & $\begin{array}{l}13.7 \\
2.05 \\
0.304 \\
0.0430\end{array}$ & $\begin{array}{l}9.30 \\
1.64 \\
0.236 \\
0.0336\end{array}$ & $\begin{array}{l}7.71 \\
1.30 \\
0.188 \\
0.0262\end{array}$ & $\begin{array}{l}6.36 \\
1.03 \\
0.146 \\
0.0205\end{array}$ & $\begin{array}{l}12 \\
790 \\
114 \\
0160\end{array}$ & $\begin{array}{l}3.99 \\
0.630 \\
0.0899 \\
0.0125\end{array}$ & $\begin{array}{l}3.22 \\
0.497 \\
0.0703 \\
0.0098\end{array}$ & $\begin{array}{l}2.62 \\
0.384 \\
0.0549 \\
0.0077\end{array}$ \\
\hline & $\begin{array}{l}13.8 \\
2.09 \\
0.302 \\
0.0430\end{array}$ & $\begin{array}{l}9.30 \\
1.67 \\
0.240 \\
0.0337\end{array}$ & $\begin{array}{l}7.71 \\
1.30 \\
0.187 \\
0.0263\end{array}$ & $\begin{array}{l}0.147 \\
0.0205\end{array}$ & & $\begin{array}{l}4.09 \\
0.625 \\
0.0896 \\
0.0125\end{array}$ & $\begin{array}{l}3.29 \\
0.499 \\
0.0704 \\
0.0098\end{array}$ & $\begin{array}{l}2.63 \\
0.385 \\
0.0550 \\
0.0077\end{array}$ \\
\hline
\end{tabular}

\begin{tabular}{|c|c|c|c|c|c|c|c|}
\hline $\begin{array}{l}13.7 \\
2.08 \\
0.298 \\
0.0430\end{array}$ & $\begin{array}{l}9.30 \\
1.63 \\
0.238 \\
0.0336\end{array}$ & $\begin{array}{l}7.71 \\
1.30 \\
0.188 \\
0.0263\end{array}$ & $\begin{array}{l}6.36 \\
1.03 \\
0.146 \\
0.0205\end{array}$ & $\begin{array}{l}5.10 \\
0.809 \\
0.115 \\
0.0161\end{array}$ & $\begin{array}{l}4.07 \\
0.627 \\
0.0899 \\
0.0125\end{array}$ & $\begin{array}{l}3.27 \\
0.490 \\
0.0701 \\
0.0098\end{array}$ & $\begin{array}{l}2.62 \\
0.390 \\
0.0550 \\
0.0077\end{array}$ \\
\hline
\end{tabular}

$\begin{array}{cllllllll}\text { MK } & 13.9 & 9.31 & 7.72 & 6.36 & 5.11 & 4.07 & 3.27 & 2.57 \\ & 2.07 & 1.66 & 1.30 & 1.03 & 0.809 & 0.633 & 0.490 & 0.390 \\ 0.304 & 0.235 & 0.186 & 0.146 & 0.114 & 0.0899 & 0.0701 & 0.0548 \\ & 0.0430 & 0.0336 & 0.0263 & 0.0205 & 0.0160 & 0.0125 & 0.0098 & 0.0077\end{array}$

$\begin{array}{lllllllll}\text { MM } & 13.7 & 8.84 & 7.71 & 6.36 & 5.10 & 3.98 & 3.27 & 2.62\end{array}$

$\begin{array}{llllllll}2.08 & 1.66 & 1.30 & 1.02 & 0.809 & 0.627 & 0.487 & 0.384\end{array}$

$\begin{array}{lllllllll}0.305 & 0.233 & 0.188 & 0.147 & 0.114 & 0.0885 & 0.0701 & 0.0548\end{array}$

$\begin{array}{lllllllll}0.0430 & 0.0336 & 0.0263 & 0.0205 & 0.0160 & 0.0125 & 0.0098 & 0.0077\end{array}$

MN $\begin{array}{cllllllll}13.8 & 9.30 & 7.71 & 6.36 & 5.10 & 4.07 & 3.27 & 2.58 \\ & 2.08 & 1.66 & 1.30 & 1.03 & 0.809 & 0.614 & 0.499 & 0.389 \\ & 0.303 & 0.234 & 0.187 & 0.146 & 0.114 & 0.0896 & 0.0703 & 0.0550 \\ & 0.0430 & 0.0337 & 0.0263 & 0.0205 & 0.0160 & 0.0125 & 0.0098 & 0.0077 \\ & & & & & & & & \\ \text { MP } & 13.6 & 9.30 & 7.71 & 6.36 & 5.10 & 4.08 & 3.28 & 2.62 \\ & 2.08 & 1.66 & 1.31 & 1.03 & 0.810 & 0.623 & 0.494 & 0.388 \\ & 0.304 & 0.236 & 0.186 & 0.146 & 0.114 & 0.0892 & 0.0703 & 0.0548 \\ & 0.0430 & 0.0337 & 0.0262 & 0.0205 & 0.0160 & 0.0125 & 0.0098 & 0.0077\end{array}$

$\begin{array}{lllllllll}\text { MR } & 13.7 & 9.30 & 7.40 & 6.36 & 4.83 & 4.07 & 3.27 & 2.62\end{array}$

$\begin{array}{llllllll}2.08 & 1.66 & 1.31 & 1.03 & 0.810 & 0.625 & 0.499 & 0.390\end{array}$

$\begin{array}{lllllllll}0.305 & 0.238 & 0.187 & 0.146 & 0.115 & 0.0899 & 0.0704 & 0.0550\end{array}$

$\begin{array}{lllllllll}0.0430 & 0.0336 & 0.0262 & 0.0205 & 0.0161 & 0.0125 & 0.0098 & 0.0077\end{array}$

$\begin{array}{lllllllll}\text { MS } & 13.8 & 8.84 & 7.40 & 6.36 & 5.10 & 4.07 & 3.27 & 2.62\end{array}$

$\begin{array}{llllllll}2.08 & 1.67 & 1.31 & 1.03 & 0.810 & 0.632 & 0.5 & 0.386\end{array}$

$\begin{array}{llllllll}0.303 & 0.238 & 0.184 & 0.146 & 0.115 & 0.0896 & 0.0704 & 0.0550\end{array}$

$\begin{array}{lllllllll}0.0430 & 0.0337 & 0.0263 & 0.0205 & 0.0160 & 0.0125 & 0.0098 & 0.0077\end{array}$

$\begin{array}{lllllllll}\text { MT } & 13.7 & 9.30 & 7.71 & 6.36 & 5.10 & 4.07 & 3.26 & 2.61\end{array}$

$\begin{array}{llllllll}2.08 & 1.66 & 1.31 & 1.03 & 0.810 & 0.634 & 0.5 & 0.388\end{array}$

$\begin{array}{llllllll}0.303 & 0.237 & 0.188 & 0.147 & 0.114 & 0.09 & 0.0704 & 0.0550\end{array}$

$\begin{array}{llllllll}0.0430 & 0.0336 & 0.0263 & 0.0206 & 0.0161 & 0.0125 & 0.0098 & 0.0077\end{array}$ 
Table A5a (Continued)

ID

Pore Diameter (micrometers) for Data in Table A5b

MU
$13.7 \quad 9.30$
7.71
6.36
$4.96 \quad 4.07$
3.26
2.61
$2.05 \quad 1.66$
1.30
1.02
0.798 .
$\begin{array}{lll}0.631 & 0.492 & 0.386\end{array}$
0.303
0.237
0.187
0.147
$\begin{array}{lllll}0.115 & 0.0899 & 0.0703 & 0.0550\end{array}$
0.0430
0.0263
$\begin{array}{llllll}0.0205 & 0.0161 & 0.0125 & 0.0098 & 0.0077\end{array}$

$\begin{array}{lcllllllll}\text { Z1 } & \text { PB } & 13.9 & 9.30 & 7.71 & 6.36 & 5.11 & 3.99 & 3.27 & 2.62 \\ & 2.08 & 1.64 & 1.27 & 1.02 & 0.793 & 0.617 & 0.498 & 0.386 \\ & 0.303 & 0.239 & 0.187 & 0.147 & 0.115 & 0.0896 & 0.0699 & 0.0548 \\ & & 0.0430 & 0.0337 & 0.0263 & 0.0205 & 0.0161 & 0.0125 & 0.0098 & 0.0077 \\ & & & & & & & & & \\ & \text { PC } & 13.9 & 9.30 & 7.72 & 6.36 & 5.12 & 4 . & 3.23 & 2.62 \\ & 2.06 & 1.65 & 1.28 & 1.02 & 0.805 & 0.6 & 0.485 & 0.386 \\ & & 0.304 & 0.238 & 0.187 & 0.146 & 0.114 & 0.0896 & 0.0701 & 0.0550 \\ & & 0.0430 & 0.0337 & 0.0263 & 0.0205 & 0.0161 & 0.0125 & 0.0098 & 0.0077\end{array}$

$\begin{array}{lllllllll}\text { PD } & 13.8 & 9.30 & 7.71 & 6.36 & 5.12 & 4.08 & 3.28 & 2.62\end{array}$ $\begin{array}{llllllll}2.08 & 1.63 & 1.30 & 1.03 & 0.784 & 0.629 & 0.497 & 0.389\end{array}$

$\begin{array}{llllllll}0.304 & 0.239 & 0.187 & 0.147 & 0.115 & 0.0899 & 0.0703 & 0.0547\end{array}$

$\begin{array}{lllllllll}0.0430 & 0.0337 & 0.0263 & 0.0205 & 0.0161 & 0.0125 & 0.0098 & 0.0077\end{array}$

$\begin{array}{cllllllll}\text { PE } & 13.7 & 9.30 & 7.72 & 6.37 & 5.12 & 4.09 & 3.28 & 2.62 \\ & 2.06 & 1.66 & 1.30 & 1.03 & 0.801 & 0.626 & 0.484 & 0.384 \\ & 0.302 & 0.240 & 0.185 & 0.147 & 0.115 & 0.0896 & 0.0703 & 0.0548 \\ & 0.0430 & 0.0337 & 0.0263 & 0.0205 & 0.0160 & 0.0125 & 0.0098 & 0.0077\end{array}$

$\begin{array}{lllllllll}\text { PF } & 13.9 & 8.84 & 7.71 & 6.36 & 5.11 & 4.08 & 3.28 & 2.62\end{array}$

$\begin{array}{llllllll}2.06 & 1.66 & 1.30 & 1.03 & 0.809 & 0.633 & 0.494 & 0.385\end{array}$

$\begin{array}{lllllllll}0.3 & 0.237 & 0.187 & 0.147 & 0.115 & 0.0899 & 0.0704 & 0.0548\end{array}$

$\begin{array}{lllllllll}0.0430 & 0.0336 & 0.0262 & 0.0205 & 0.0161 & 0.0125 & 0.0098 & 0.0077\end{array}$

$\begin{array}{lllllllll}\text { PG } & 13.7 & 9.30 & 7.72 & 6.37 & 5.12 & 4.09 & 3.28 & 2.58\end{array}$

$\begin{array}{llllllll}2.08 & 1.66 & 1.28 & 1.03 & 0.805 & 0.633 & 0.499 & 0.388\end{array}$

$\begin{array}{llllllll}0.302 & 0.238 & 0.187 & 0.147 & 0.115 & 0.0899 & 0.0703 & 0.0548\end{array}$

$\begin{array}{llllllllll}0.0430 & 0.0336 & 0.0263 & 0.0205 & 0.0161 & 0.0125 & 0.0098 & 0.0077\end{array}$

$\begin{array}{lllllllll}\mathrm{PH} & - & 8.85 & 7.40 & 6.37 & 4.99 & 4.10 & 3.29 & 2.63\end{array}$

$\begin{array}{llllllll}2.09 & 1.65 & 1.31 & 1.03 & 0.810 & 0.627 & 0.496 & 0.388\end{array}$

$\begin{array}{lllllllll}0.303 & 0.238 & 0.184 & 0.147 & 0.115 & 0.0899 & 0.0703 & 0.0550\end{array}$

$\begin{array}{lllllllll}0.0430 & 0.0336 & 0.0263 & 0.0205 & 0.0160 & 0.0125 & 0.0098 & 0.0077\end{array}$

$\begin{array}{llllllllll}\mathrm{Z} 2 & \mathrm{SB} & 14.2 & 8.85 & 7.72 & 6.36 & 5.11 & 4 . & 3.28 & 2.59\end{array}$

$\begin{array}{llllllll}2.08 & 1.63 & 1.30 & 1 . & 0.802 & 0.625 & 0.496 & 0.390\end{array}$

$\begin{array}{lllllllll}0.302 & 0.238 & 0.187 & 0.147 & 0.115 & 0.0899 & 0.0701 & 0.0548\end{array}$

$\begin{array}{lllllllll}0.0430 & 0.0336 & 0.0262 & 0.0205 & 0.0161 & 0.0125 & 0.0098 & 0.0077\end{array}$

$\begin{array}{lllllllll}\text { SC } & 13.8 & 8.85 & 7.72 & 5.95 & 5.12 & 4.09 & 3.28 & 2.62\end{array}$

$\begin{array}{lllllllll}2.08 & 1.60 & 1.29 & 1.02 & 0.801 & 0.627 & 0.499 & 0.390\end{array}$

$\begin{array}{lllllllll}0.306 & 0.240 & 0.188 & 0.146 & 0.115 & 0.0896 & 0.0704 & 0.0548\end{array}$ $\begin{array}{lllllllll}0.0430 & 0.0337 & 0.0262 & 0.0205 & 0.0161 & 0.0125 & 0.0098 & 0.0077\end{array}$ 
Table A5a (Continued)

\begin{tabular}{ccccccclll} 
ID & \multicolumn{6}{c}{ Pore Diameter (micrometers) for Data in Table A5b } \\
SD $\quad 13.9$ & 9.30 & 7.74 & 6.40 & 5.01 & 4.11 & 3.29 & 2.63 \\
& 2.06 & 1.66 & 1.30 & 1.02 & 0.809 & 0.633 & 0.498 & 0.389 \\
& 0.303 & 0.239 & 0.187 & 0.146 & 0.115 & 0.0899 & 0.0701 & 0.0548 \\
& 0.0429 & 0.0336 & 0.0262 & 0.0205 & 0.0160 & 0.0125 & 0.0098 & 0.0077
\end{tabular}

$\begin{array}{cllllllll}\text { SE } & 13.7 & 8.85 & 7.71 & 6.37 & 5.12 & 4 . & 3.28 & 2.62 \\ & 2.08 & 1.65 & 1.30 & 1.03 & 0.798 & 0.633 & 0.491 & 0.390 \\ & 0.304 & 0.238 & 0.187 & 0.147 & 0.115 & 0.0899 & 0.0703 & 0.0550 \\ & 0.0430 & 0.0337 & 0.0263 & 0.0206 & 0.0161 & 0.0125 & 0.0098 & 0.0077\end{array}$

$\begin{array}{lllllllll}\text { SF } & 13.8 & 9.30 & 7.72 & 6.37 & 5.12 & 4.10 & 3.30 & 2.63\end{array}$

$\begin{array}{lllllllll}2.06 & 1.65 & 1.29 & 1.03 & 0.806 & 0.634 & 0.494 & 0.391\end{array}$

$\begin{array}{lllllllll}0.300 & 0.238 & 0.187 & 0.147 & 0.115 & 0.0896 & 0.0699 & 0.0548\end{array}$

$\begin{array}{lllllllll}0.0430 & 0.0337 & 0.0263 & 0.0205 & 0.0161 & 0.0125 & 0.0098 & 0.0077\end{array}$

$\begin{array}{lllllllll}\text { SG } & 13.9 & 9.30 & 7.71 & 6.14 & 5.10 & 4.07 & 3.27 & 2.61\end{array}$

$\begin{array}{llllllll}2.07 & 1.66 & 1.30 & 1.03 & 0.786 & 0.632 & 0.498 & 0.387\end{array}$

$\begin{array}{lllllllll}0.303 & 0.237 & 0.188 & 0.146 & 0.115 & 0.0896 & 0.0703 & 0.0549\end{array}$

$\begin{array}{llllllllll}0.0430 & 0.0337 & 0.0263 & 0.0206 & 0.0160 & 0.0125 & 0.0098 & 0.0077\end{array}$

$\begin{array}{lllllllll}\text { SH } & 13.8 & 9.30 & 7.40 & 6.14 & 5.11 & 4.08 & 3.28 & 2.62\end{array}$

$\begin{array}{lllllllll}2.06 & 1.66 & 1.30 & 1.03 & 0.805 & 0.624 & 0.497 & 0.389\end{array}$

$\begin{array}{lllllllll}0.301 & 0.238 & 0.188 & 0.146 & 0.115 & 0.0899 & 0.0701 & 0.0550\end{array}$

$\begin{array}{lllllllll}0.0430 & 0.0337 & 0.0263 & 0.0205 & 0.0161 & 0.0125 & 0.0098 & 0.0077\end{array}$

$\begin{array}{lllllllll}\text { SJ } & 13.6 & 8.85 & 7.40 & 6.14 & 5.11 & 4.08 & 3.28 & 2.62 \\ & 2.08 & 1.66 & 1.30 & 1.03 & 0.799 & 0.625 & 0.496 & 0.390 \\ & 0.305 & 0.238 & 0.188 & 0.146 & 0.115 & 0.0896 & 0.0701 & 0.0546 \\ & 0.0430 & 0.0336 & 0.0262 & 0.0205 & 0.0160 & 0.0125 & 0.0098 & 0.0077\end{array}$

$\begin{array}{lllllllll}\text { SK } & 13.7 & 9.30 & 7.40 & 6.36 & 4.96 & 4.07 & 3.28 & 2.62\end{array}$

$\begin{array}{llllllll}2.08 & 1.66 & 1.29 & 1.03 & 0.809 & 0.631 & 0.492 & 0.382\end{array}$

$\begin{array}{lllllllll}0.304 & 0.239 & 0.188 & 0.147 & 0.115 & 0.0896 & 0.0701 & 0.0550\end{array}$

$\begin{array}{lllllllll}0.0430 & 0.0337 & 0.0262 & 0.0205 & 0.0161 & 0.0125 & 0.0098 & 0.0077\end{array}$

$\begin{array}{lllllllll}\text { SM } & 13.8 & 8.85 & 7.40 & 6.14 & 5.11 & 3.99 & 3.28 & 2.62\end{array}$

$\begin{array}{llllllll}2.06 & 1.66 & 1.30 & 1.03 & 0.809 & 0.629 & 0.499 & 0.387\end{array}$

$\begin{array}{llllllll}0.302 & 0.238 & 0.186 & 0.146 & 0.115 & 0.0892 & 0.0701 & 0.0550\end{array}$

$\begin{array}{lllllllll}0.0430 & 0.0336 & 0.0263 & 0.0205 & 0.0160 & 0.0125 & 0.0098 & 0.0077\end{array}$

$\begin{array}{lllllllll}\text { SN } & 13.8 & 9.08 & 7.56 & 5.67 & 4.53 & 3.56 & 2.80 & 2.20\end{array}$

$\begin{array}{llllllll}1.72 & 1.35 & 1.05 & 0.819 & 0.644 & 0.502 & 0.386 & 0.305\end{array}$

$\begin{array}{lllllllll}0.239 & 0.187 & 0.148 & 0.115 & 0.0898 & 0.0705 & 0.0550 & 0.0431\end{array}$

$\begin{array}{llllllll}0.0337 & 0.0263 & 0.0206 & 0.0161 & 0.0125 & 0.0098 & 0.0077\end{array}$

$\begin{array}{lllllllll}\text { SP } & 13.7 & 9.30 & 7.71 & 6.14 & 5.10 & 4.07 & 3.27 & 2.63\end{array}$

$\begin{array}{llllllll}2.09 & 1.67 & 1.31 & 1.03 & 0.812 & 0.635 & 0.491 & 0.385\end{array}$

$\begin{array}{llllllll}0.306 & 0.240 & 0.186 & 0.146 & 0.115 & 0.09 & 0.0704 & 0.0548\end{array}$

$\begin{array}{lllllllll}0.0430 & 0.0337 & 0.0263 & 0.0205 & 0.0161 & 0.0125 & 0.0098 & 0.0077\end{array}$ 
ID Pore Diameter (micrometers) for Data in Table A5b

\begin{tabular}{|c|c|c|c|c|c|c|c|c|}
\hline UW & $\begin{array}{l}13.8 \\
2.08 \\
0.303 \\
0.0429\end{array}$ & $\begin{array}{l}9.30 \\
1.64 \\
0.238 \\
0.0337\end{array}$ & $\begin{array}{l}7.71 \\
1.29 \\
0.187 \\
0.0263\end{array}$ & $\begin{array}{l}6.15 \\
1.03 \\
0.147 \\
0.0205\end{array}$ & $\begin{array}{l}4.97 \\
0.808 \\
0.115 \\
0.0161\end{array}$ & $\begin{array}{l}4.09 \\
0.626 \\
0.0899 \\
0.0125\end{array}$ & $\begin{array}{l}3.28 \\
0.499 \\
0.0701 \\
0.0098\end{array}$ & $\begin{array}{l}2.62 \\
0.388 \\
0.0550 \\
0.0077\end{array}$ \\
\hline $\mathbf{U}$ & $\begin{array}{l}14.0 \\
2.09 \\
0.302 \\
0.0430\end{array}$ & $\begin{array}{l}8.85 \\
1.66 \\
0.239 \\
0.0336\end{array}$ & $\begin{array}{l}7.73 \\
1.31 \\
0.188 \\
0.0263\end{array}$ & $\begin{array}{l}1.03 \\
0.147 \\
0.0205\end{array}$ & $\begin{array}{l}5.13 \\
0.806 \\
0.115 \\
0.0160\end{array}$ & $\begin{array}{l}4.02 \\
0.623 \\
0.0896 \\
0.0125\end{array}$ & $\begin{array}{l}3.24 \\
0.497 \\
0.0704 \\
0.0098\end{array}$ & 0.007 \\
\hline
\end{tabular}

$\begin{array}{cllllllll}\text { UD } & 14.0 & 9.48 & 7.84 & 6.22 & 5.16 & 4.11 & 3.30 & 2.59 \\ & 2.04 & 1.66 & 1.30 & 1.03 & 0.798 & 0.634 & 0.487 & 0.385 \\ & 0.305 & 0.239 & 0.186 & 0.145 & 0.115 & 0.0899 & 0.0703 & 0.0550 \\ & 0.0429 & 0.0337 & 0.0263 & 0.0205 & 0.0161 & 0.0125 & 0.0098 & 0.0077 \\ & & & & & & & & \\ \text { UE } \quad 13.8 & 9.30 & 7.72 & 6.15 & 5.12 & 4.09 & 3.22 & 2.62 \\ & 2.06 & 1.62 & 1.28 & 1.02 & 0.794 & 0.620 & 0.499 & 0.383 \\ & 0.303 & 0.238 & 0.188 & 0.147 & 0.115 & 0.0896 & 0.0701 & 0.0550 \\ & 0.0430 & 0.0336 & 0.0263 & 0.0205 & 0.0161 & 0.0125 & 0.0098 & 0.0077\end{array}$

\begin{tabular}{|c|c|c|c|c|c|c|c|}
\hline $\begin{array}{l}13.7 \\
2.06 \\
0.305 \\
0.0430\end{array}$ & $\begin{array}{l}9.30 \\
1.65 \\
0.239 \\
0.0337\end{array}$ & $\begin{array}{l}7.72 \\
1.30 \\
0.187 \\
0.0263\end{array}$ & $\begin{array}{l}6.38 \\
1.03 \\
0.146 \\
0.0205\end{array}$ & $\begin{array}{l}5.13 \\
0.795 \\
0.115 \\
0.0161\end{array}$ & $\begin{array}{l}4.09 \\
0.622 \\
0.0896 \\
0.0125\end{array}$ & $\begin{array}{l}3.29 \\
0.493 \\
0.0699 \\
0.0098\end{array}$ & $\begin{array}{l}2.62 \\
0.383 \\
0.0550 \\
0.0077\end{array}$ \\
\hline
\end{tabular}

$\begin{array}{lllllllll}\text { UG } & 13.8 & 9.30 & 7.40 & 6.37 & 5.12 & 4.10 & 3.29 & 2.63\end{array}$ $\begin{array}{llllllll}2.08 & 1.65 & 1.31 & 1.02 & 0.806 & 0.632 & 0.499 & 0.385\end{array}$ $\begin{array}{lllllllll}0.304 & 0.238 & 0.187 & 0.147 & 0.115 & 0.0899 & 0.0701 & 0.0550\end{array}$ $\begin{array}{lllllllll}0.0430 & 0.0337 & 0.0262 & 0.0206 & 0.0161 & 0.0125 & 0.0098 & 0.0077\end{array}$

$\begin{array}{llllllllll} & \mathrm{UH} & 13.8 & 8.85 & 7.72 & 6.14 & 5.11 & 4.07 & 3.27 & 2.62\end{array}$ $\begin{array}{llllllll}2.08 & 1.66 & 1.29 & 1.02 & 0.805 & 0.624 & 0.495 & 0.381\end{array}$ $\begin{array}{lllllllll}0.302 & 0.239 & 0.187 & 0.147 & 0.114 & 0.0899 & 0.0701 & 0.0547\end{array}$ $\begin{array}{lllllllll}0.0430 & 0.0336 & 0.0263 & 0.0205 & 0.0161 & 0.0125 & 0.0098 & 0.0077\end{array}$

\begin{tabular}{|c|c|c|c|c|c|c|}
\hline $\begin{array}{l}13.8 \\
2.08 \\
0.297 \\
0.0430\end{array}$ & $\begin{array}{l}9 \\
1 \\
0 \\
0\end{array}$ & $\begin{array}{l}7.40 \\
1.29 \\
0.185 \\
0.0263\end{array}$ & $\begin{array}{l}6.36 \\
1.03 \\
0.147 \\
0.0205\end{array}$ & $\begin{array}{l}4.97 \\
0.802 \\
0.115 \\
0.0161\end{array}$ & $\begin{array}{l}4.08 \\
0.629 \\
0.0899 \\
0.0125\end{array}$ & $\begin{array}{ll}2.62 \\
0.390 \\
3 & 0.0548 \\
8 & 0.0077\end{array}$ \\
\hline
\end{tabular}

$\begin{array}{lllllllll}\text { UK } & 13.6 & 9.30 & 7.71 & 6.36 & 5.10 & 4.07 & 3.21 & 2.61\end{array}$ $\begin{array}{llllllll}2.08 & 1.66 & 1.30 & 1.03 & 0.809 & 0.633 & 0.499 & 0.386\end{array}$ $\begin{array}{lllllllll}0.303 & 0.239 & 0.188 & 0.147 & 0.115 & 0.0899 & 0.0703 & 0.0548\end{array}$ $\begin{array}{llllllll}0.0430 & 0.0337 & 0.0263 & 0.0205 & 0.0160 & 0.0125 & 0.0098 & 0.0077\end{array}$

\begin{tabular}{|c|c|c|c|c|c|c|c|}
\hline $\begin{array}{l}13.7 \\
2.08 \\
0.303 \\
0.0430\end{array}$ & $\begin{array}{l}8.84 \\
1.66 \\
0.238 \\
0.0337\end{array}$ & $\begin{array}{l}7.71 \\
1.31 \\
0.187 \\
0.0263\end{array}$ & $\begin{array}{l}6.14 \\
1.03 \\
0.147 \\
0.0205\end{array}$ & $\begin{array}{l}5.10 \\
0.810 \\
0.115 \\
0.0161\end{array}$ & $\begin{array}{l}4.07 \\
0.634 \\
0.0899 \\
0.0125\end{array}$ & $\begin{array}{l}3.27 \\
0.5 \\
0.0704 \\
0.0098\end{array}$ & $\begin{array}{l}2.62 \\
0.382 \\
0.0548 \\
0.0077\end{array}$ \\
\hline
\end{tabular}


Table A5a (Continued)

ID

Pore Diameter (micrometers) for Data in Table A5b

\begin{tabular}{|c|c|c|c|c|c|c|c|c|}
\hline 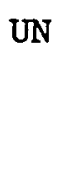 & $\begin{array}{l}13.6 \\
2.08 \\
0.306 \\
0.0430\end{array}$ & $\begin{array}{l}9.30 \\
1.66 \\
0.239 \\
0.0337\end{array}$ & $\begin{array}{l}7.40 \\
1.30 \\
0.186 \\
0.0263\end{array}$ & $\begin{array}{l}6.36 \\
1.03 \\
0.147 \\
0.0205\end{array}$ & $\begin{array}{l}5.10 \\
0.810 \\
0.115 \\
0.0160\end{array}$ & $\begin{array}{l}4.07 \\
0.627 \\
0.0899 \\
0.0125\end{array}$ & $\begin{array}{l}3.27 \\
0.495 \\
0.0703 \\
0.0098\end{array}$ & $\begin{array}{l}2.62 \\
0.390 \\
0.0550 \\
0.0077\end{array}$ \\
\hline UP & $\begin{array}{l}13.7 \\
2.08 \\
0.304 \\
0.0429\end{array}$ & $\begin{array}{l}9.32 \\
1.65 \\
0.234 \\
0.0337\end{array}$ & $\begin{array}{l}7.75 \\
1.30 \\
0.186 \\
0.0262\end{array}$ & $\begin{array}{l}6.18 \\
1.03 \\
0.145 \\
0.0205\end{array}$ & $\begin{array}{l}5.14 \\
0.808 \\
0.114 \\
0.0161\end{array}$ & $\begin{array}{l}4.01 \\
0.631 \\
0.0899 \\
0.0125\end{array}$ & $\begin{array}{l}3.28 \\
0.489 \\
0.0701 \\
\quad-\end{array}$ & $\begin{array}{l}2.58 \\
0.382 \\
0.0550 \\
\quad-\end{array}$ \\
\hline $\mathrm{U}$ & $\begin{array}{l}13.8 \\
2.08 \\
0.305 \\
0.0430\end{array}$ & $\begin{array}{l}8.84 \\
1.66 \\
0.236 \\
0.0337\end{array}$ & $\begin{array}{l}7.40 \\
1.30 \\
0.186 \\
0.0262\end{array}$ & $\begin{array}{l}6.14 \\
1.03 \\
0.147 \\
0.0205\end{array}$ & $\begin{array}{l}4.96 \\
0.806 \\
0.114 \\
0.0160\end{array}$ & $\begin{array}{l}3.98 \\
0.621 \\
0.0896 \\
0.0125\end{array}$ & $\begin{array}{l}3.27 \\
0.499 \\
0.0704 \\
0.0098\end{array}$ & $\begin{array}{l}2.62 \\
0.391 \\
0.0547 \\
0.0077\end{array}$ \\
\hline US & $\begin{array}{l}13.7 \\
2.08 \\
0.306 \\
0.0430\end{array}$ & $\begin{array}{l}8.84 \\
1.67 \\
0.238 \\
0.0337\end{array}$ & $\begin{array}{l}7.71 \\
1.31 \\
0.187 \\
0.0262\end{array}$ & $\begin{array}{l}6.36 \\
1.03 \\
0.146 \\
0.0205\end{array}$ & $\begin{array}{l}5.10 \\
0.8 \\
0.114 \\
0.0161\end{array}$ & $\begin{array}{l}4.07 \\
0.623 \\
0.0896 \\
0.0125\end{array}$ & $\begin{array}{l}3.27 \\
0.495 \\
0.0704 \\
0.0098\end{array}$ & $\begin{array}{l}2.62 \\
0.384 \\
0.0550 \\
0.0077\end{array}$ \\
\hline UT & $\begin{array}{l}13.7 \\
2.09 \\
0.301 \\
0.0430\end{array}$ & $\begin{array}{l}8.84 \\
1.67 \\
0.238 \\
0.0336\end{array}$ & $\begin{array}{l}7.40 \\
1.31 \\
0.187 \\
0.0262\end{array}$ & $\begin{array}{l}6.36 \\
1.03 \\
0.147 \\
0.0205\end{array}$ & $\begin{array}{l}5.10 \\
0.811 \\
0.115 \\
0.0160\end{array}$ & $\begin{array}{l}4.07 \\
0.630 \\
0.0892 \\
0.0125\end{array}$ & $\begin{array}{l}3.27 \\
0.495 \\
0.0704 \\
0.0098\end{array}$ & $\begin{array}{l}2.62 \\
0.386 \\
0.0548 \\
0.0077\end{array}$ \\
\hline UUU & $\begin{array}{l}\quad- \\
2.05 \\
0.304 \\
0.0430\end{array}$ & $\begin{array}{l}9.30 \\
1.66 \\
0.240 \\
0.0337\end{array}$ & $\begin{array}{l}7.71 \\
1.30 \\
0.187 \\
0.0262\end{array}$ & $\begin{array}{l}6.14 \\
1.03 \\
0.147 \\
0.0205\end{array}$ & $\begin{array}{l}4.96 \\
0.799 \\
0.115 \\
0.0161\end{array}$ & $\begin{array}{l}4.07 \\
0.634 \\
0.0896 \\
0.0125\end{array}$ & $\begin{array}{l}3.27 \\
0.498 \\
0.0701 \\
0.0098\end{array}$ & $\begin{array}{l}2.61 \\
0.385 \\
0.0550 \\
0.0077\end{array}$ \\
\hline
\end{tabular}


Table A5b: Cumulative volumetric porosity, expressed in units of $\mathrm{m}^{3}$ water per $\mathrm{m}^{3}$ rock, determined from mercury intrusion volumes for 105 medium core segments. Table is for equivalent pore diameters reported in Table A5a.

ID Cumulative Volumetric Porosity $\left(\mathrm{m}^{3} / \mathrm{m}^{3}\right)$ for Data in Table A5a

$\begin{array}{llllllllllllll}\mathrm{X} 1 & \mathrm{AA} & 0.0000 & 0.0004 & 0.0004 & 0.0006 & 0.0019 & 0.0027 & 0.0076 & 0.0165\end{array}$

$\begin{array}{llllllllll}0.0228 & 0.0266 & 0.0293 & 0.0316 & 0.0346 & 0.0373 & 0.0399 & 0.0426\end{array}$

$\begin{array}{llllllllll}0.0454 & 0.0483 & 0.0506 & 0.0536 & 0.0578 & 0.0669 & 0.0760 & 0.0827\end{array}$

$\begin{array}{llllllll}0.0884 & 0.0931 & 0.0973 & 0.1009 & 0.1036 & 0.1059 & 0.1076 & 0.1091\end{array}$

$\begin{array}{llllllllll}\mathrm{AB} & 0.0000 & 0.0004 & 0.0011 & 0.0028 & 0.0068 & 0.0121 & 0.0185 & 0.0239\end{array}$

$\begin{array}{lllllllll}0.0285 & 0.0324 & 0.0354 & 0.0392 & 0.0422 & 0.0454 & 0.0484 & 0.0511\end{array}$

$\begin{array}{lllllllll}0.0539 & 0.0564 & 0.0590 \cdot 0.0620 & 0.0665 & 0.0752 & 0.0843 & 0.0912\end{array}$

$\begin{array}{lllllllll}0.0973 & 0.1024 & 0.1067 & 0.1101 & 0.1127 & 0.1150 & 0.1165 & 0.1178\end{array}$

AC $\quad \begin{array}{lllllllll}0.0000 & 0.0004 & 0.0019 & 0.0045 & 0.0110 & 0.0196 & 0.0288 & 0.0370\end{array}$

$\begin{array}{llllllllll}0.0419 & 0.0452 & 0.0479 & 0.0507 & 0.0540 & 0.0568 & 0.0598 & 0.0619\end{array}$

$\begin{array}{llllllllll}0.0645 & 0.0669 & 0.0697 & 0.0727 & 0.0783 & 0.0886 & 0.0983 & 0.1058\end{array}$

$\begin{array}{lllllllll}0.1127 & 0.1185 & 0.1232 & 0.1264 & 0.1294 & 0.1318 & 0.1337 & 0.1350\end{array}$

$\mathrm{AD} \quad \begin{array}{llllllll}0.0000 & 0.0000 & 0.0000 & 0.0000 & 0.0000 & 0.0000 & 0.0007 & 0.0076\end{array}$ $\begin{array}{lllllllll}0.0148 & 0.0177 & 0.0198 & 0.0222 & 0.0255 & 0.0286 & 0.0320 & 0.0353\end{array}$ $\begin{array}{lllllllll}0.0353 & 0.0416 & 0.0449 & 0.0484 & 0.0525 & 0.0604 & 0.0739 & 0.0831\end{array}$ $\begin{array}{lllllllll}0.0905 & 0.0964 & 0.1020 & 0.1057 & 0.1090 & 0.1116 & 0.1134 & 0.1151\end{array}$

AE $\quad \begin{array}{lllllllll}0.0000 & 0.0002 & 0.0004 & 0.0026 & 0.0076 & 0.0150 & 0.0242 & 0.0336\end{array}$ $\begin{array}{llllllllll}0.0399 & 0.0440 & 0.0464 & 0.0499 & 0.0534 & 0.0567 & 0.0600 & 0.0626\end{array}$ $\begin{array}{llllllllll}0.0654 & 0.0685 & 0.0711 & 0.0746 & 0.0780 & 0.0833 & 0.0920 & 0.1001\end{array}$ $\begin{array}{lllllllll}0.1066 & 0.1123 & 0.1166 & 0.1199 & 0.1230 & 0.1247 & 0.1262 & 0.1275\end{array}$

AF $\quad \begin{array}{lllllllll}0.0000 & 0.0000 & 0.0000 & 0.0006 & 0.0037 & 0.0143 & 0.0276 & 0.0367\end{array}$ $\begin{array}{llllllllll}0.0462 & 0.0516 & 0.0564 & 0.0616 & 0.0659 & 0.0698 & 0.0730 & 0.0765\end{array}$ $\begin{array}{lllllllll}0.0799 & 0.0832 & 0.0870 & 0.0907 & 0.0948 & 0.1004 & 0.1080 & 0.1190\end{array}$ $\begin{array}{lllllllll}0.1285 & 0.1356 & 0.1406 & 0.1441 & 0.1467 & 0.1488 & 0.1503 & 0.1514\end{array}$

AG

$\begin{array}{lllllllll}0.0000 & 0.0002 & 0.0002 & 0.0004 & 0.0024 & 0.0091 & 0.0208 & 0.0279\end{array}$

$\begin{array}{llllllllll}0.0329 & 0.0370 & 0.0415 & 0.0461 & 0.0517 & 0.0565 & 0.0610 & 0.0653\end{array}$

$\begin{array}{llllllllll}0.0694 & 0.0740 & 0.0779 & 0.0820 & 0.0865 & 0.0924 & 0.0997 & 0.1097\end{array}$

$\begin{array}{lllllllll}0.1177 & 0.1244 & 0.1294 & 0.1330 & 0.1356 & 0.1378 & 0.1391 & 0.1404\end{array}$

$\begin{array}{lllllllllll}\mathrm{X} 2 & \mathrm{CA} & 0.0000 & 0.0012 & 0.0112 & 0.0139 & 0.0196 & 0.0266 & 0.0354 & 0.0428\end{array}$ $\begin{array}{llllllllll}0.0428 & 0.0428 & 0.0428 & 0.0428 & 0.0428 & 0.0428 & 0.0428 & 0.0449\end{array}$ $\begin{array}{lllllllll}0.0474 & 0.0510 & 0.0564 & 0.0657 & 0.0759 & 0.0842 & 0.0913 & 0.0953\end{array}$ $\begin{array}{lllllllll}0.1011 & 0.1042 & 0.1073 & 0.1104 & 0.1414 & 0.1417 & 0.1417 & 0.1417\end{array}$

$\mathrm{CB}$

$\begin{array}{lllllllll}0.0000 & 0.0002 & 0.0006 & 0.0010 & 0.0031 & 0.0108 & 0.0177 & 0.0233\end{array}$

$\begin{array}{lllllllll}0.0275 & 0.0312 & 0.0337 & 0.0353 & 0.0369 & 0.0381 & 0.0394 & 0.0410\end{array}$

$\begin{array}{llllllllll}0.0430 & 0.0447 & 0.0473 & 0.0514 & 0.0579 & 0.0651 & 0.0712 & 0.0763\end{array}$

$\begin{array}{lllllllllll}0.0808 & 0.0847 & 0.0881 & 0.0908 & 0.0934 & 0.0955 & 0.0971 & 0.0983\end{array}$ 
Table A5b (Continued)

ID

$\mathrm{CC}$

$C D$

CE

$\mathrm{CF}$

CG

$\mathrm{CH}$

$\begin{array}{lllllllll}0.0002 & 0.0004 & 0.0020 & 0.0072 & 0.0150 & 0.0266 & 0.0377 & 0.0460\end{array}$ $\begin{array}{lllllllllll}0.0582 & 0.0676 & 0.0730 & 0.0765 & 0.0804 & 0.0837 & 0.0865 & 0.0896\end{array}$ $\begin{array}{lllllllllll}0.0922 & 0.0944 & 0.0968 & 0.0996 & 0.1027 & 0.1066 & 0.1131 & 0.1195\end{array}$ $\begin{array}{llllllllll}0.1247 & 0.1299 & 0.1347 & 0.1391 & 0.1424 & 0.1452 & 0.1471 & 0.1485\end{array}$

CJ

$\begin{array}{llllllllll}0.0000 & 0.0002 & 0.0002 & 0.0002 & 0.0011 & 0.0076 & 0.0165 & 0.0258\end{array}$ $\begin{array}{lllllllll}0.0369 & 0.0514 & 0.0614 & 0.0568 & 0.0712 & 0.0751 & 0.0792 & 0.0829\end{array}$ $\begin{array}{lllllllll}0.0861 & 0.0892 & 0.0929 & 0.0955 & 0.0985 & 0.1020 & 0.1079 & 0.1139\end{array}$ $\begin{array}{lllllllll}0.1189 & 0.1259 & 0.1298 & 0.1330 & 0.1358 & 0.1380 & 0.1398 & 0.1410\end{array}$

CK

$\begin{array}{llllllllll}0.0000 & 0.0000 & 0.0000 & 0.0000 & 0.0015 & 0.0095 & 0.0301 & 0.0432\end{array}$ $\begin{array}{llllllllll}0.0550 & 0.0645 & 0.0710 & 0.0761 & 0.0802 & 0.0834 & 0.0864 & 0.0892\end{array}$ $\begin{array}{llllllllll}0.0916 & 0.0942 & 0.0970 & 0.0998 & 0.1032 & 0.1079 & 0.1172 & 0.1271\end{array}$ $\begin{array}{lllllllll}0.1348 & 0.1421 & 0.1488 & 0.1529 & 0.1561 & 0.1580 & 0.1593 & 0.1606\end{array}$

CM

$\begin{array}{lllllllll}0.0000 & 0.0000 & 0.0002 & 0.0015 & 0.0046 & 0.0202 & 0.0328 & 0.0464\end{array}$ $\begin{array}{llllllllll}0.0605 & 0.0703 & 0.0756 & 0.0792 & 0.0825 & 0.0859 & 0.0888 & 0.0913\end{array}$ $\begin{array}{lllllllll}0.0939 & 0.0964 & 0.0987 & 0.1019 & 0.1050 & 0.1098 & 0.1180 & 0.1283\end{array}$ $\begin{array}{llllllllll}0.1363 & 0.1436 & 0.1504 & 0.1548 & 0.1581 & 0.1602 & 0.1617 & 0.1628\end{array}$

CN

$\begin{array}{lllllllll}0.0000 & 0.0002 & 0.0002 & 0.0002 & 0.0002 & 0.0006 & 0.0011 & 0.0108\end{array}$ $\begin{array}{lllllllllll}0.0413 & 0.0574 & 0.0716 & 0.0744 & 0.0774 & 0.0808 & 0.0838 & 0.0869\end{array}$ $\begin{array}{lllllllll}0.0907 & 0.0944 & 0.0972 & 0.1026 & 0.1094 & 0.1125 & 0.1159 & 0.1249\end{array}$ $\begin{array}{lllllllll}0.1363 & 0.1443 & 0.1494 & 0.1537 & 0.1555 & 0.1569 & 0.1582 & 0.1589\end{array}$ 
Table A5b (Continued)

ID Cumulative Volumetric Porosity $\left(\mathrm{m}^{3} / \mathrm{m}^{3}\right)$ for Data in Table A5a

$\begin{array}{llllllllllllll}\mathrm{X} 3 & \mathrm{EA} & 0.0000 & 0.0000 & 0.0010 & 0.0023 & 0.0049 & 0.0087 & 0.0130 & 0.0180\end{array}$ $\begin{array}{lllllllllll}0.0219 & 0.0252 & 0.0287 & 0.0316 & 0.0351 & 0.0390 & 0.0427 & 0.0473\end{array}$ $\begin{array}{llllllllll}0.0524 & 0.0576 & 0.0654 & 0.0741 & 0.0821 & 0.0887 & 0.0941 & 0.0993\end{array}$ $\begin{array}{llllllll}0.1036 & 0.1071 & 0.1106 & 0.1131 & 0.1158 & 0.1182 & 0.1199 & 0.1214\end{array}$

EB $\quad \begin{array}{llllllllll}0.0000 & 0.0002 & 0.0004 & 0.0008 & 0.0018 & 0.0038 & 0.0072 & 0.0125\end{array}$ $\begin{array}{llllllllll}0.0191 & 0.0241 & 0.0308 & 0.0342 & 0.0370 & 0.0394 & 0.0418 & 0.0446\end{array}$ $\begin{array}{llllllllll}0.0478 & 0.0525 & 0.0583 & 0.0687 & 0.0832 & 0.0951 & 0.1047 & 0.1128\end{array}$ $\begin{array}{llllllllll}0.1192 & 0.1246 & 0.1290 & 0.1327 & 0.1361 & 0.1389 & 0.1413 & 0.1429\end{array}$

EC $\quad \begin{array}{lllllllll}0.0000 & 0.0000 & 0.0021 & 0.0060 & 0.0116 & 0.0207 & 0.0337 & 0.0414\end{array}$ $\begin{array}{llllllllll}0.0474 & 0.0528 & 0.0573 & 0.0609 & 0.0631 & 0.0652 & 0.0669 & 0.0696\end{array}$ $\begin{array}{llllllllll}0.0720 & 0.0753 & 0.0795 & 0.0859 & 0.0973 & 0.1091 & 0.1188 & 0.1263\end{array}$ $\begin{array}{llllllllll}0.1325 & 0.1377 & 0.1422 & 0.1457 & 0.1493 & 0.1517 & 0.1538 & 0.1538\end{array}$

$\begin{array}{llllllllll}\text { ED } & 0.0000 & 0.0000 & 0.0004 & 0.0038 & 0.0104 & 0.0168 & 0.0236 & 0.0294\end{array}$ $\begin{array}{llllllllll}0.0356 & 0.0405 & 0.0452 & 0.0481 & 0.0518 & 0.0556 & 0.0594 & 0.0635\end{array}$ $\begin{array}{llllllllll}0.0667 & 0.0697 & 0.0728 & 0.0769 & 0.0824 & 0.0903 & 0.0982 & 0.1044\end{array}$ $\begin{array}{lllllllll}0.1097 & 0.1137 & 0.1176 & 0.1204 & 0.1229 & 0.1248 & 0.1261 & 0.1274\end{array}$

EE $\quad \begin{array}{lllllllll}0.0000 & 0.0000 & 0.0011 & 0.0043 & 0.0099 & 0.0198 & 0.0295 & 0.0370\end{array}$ $\begin{array}{llllllllll}0.0434 & 0.0486 & 0.0520 & 0.0546 & 0.0578 & 0.0608 & 0.0639 & 0.0664\end{array}$ $\begin{array}{lllllllllll}0.0692 & 0.0718 & 0.0744 & 0.0770 & 0.0806 & 0.0888 & 0.0985 & 0.1064\end{array}$ $\begin{array}{lllllllll}0.1127 & 0.1178 & 0.1217 & 0.1245 & 0.1273 & 0.1290 & 0.1305 & 0.1316\end{array}$

EF $\quad \begin{array}{lllllllll}0.0000 & 0.0000 & 0.0007 & 0.0053 & 0.0169 & 0.0265 & 0.0348 & 0.0414\end{array}$ $\begin{array}{llllllllll}0.0477 & 0.0515 & 0.0550 & 0.0578 & 0.0611 & 0.0639 & 0.0668 & 0.0694\end{array}$ $\begin{array}{llllllllll}0.0716 & 0.0742 & 0.0767 & 0.0795 & 0.0828 & 0.0891 & 0.0977 & 0.1049\end{array}$ $\begin{array}{lllllllll}0.1108 & 0.1161 & 0.1200 & 0.1233 & 0.1259 & 0.1279 & 0.1292 & 0.1305\end{array}$

EG $\quad \begin{array}{llllllllll}0.0000 & 0.0000 & 0.0000 & 0.0002 & 0.0016 & 0.0085 & 0.0227 & 0.0341\end{array}$ $\begin{array}{lllllllllll}0.0428 & 0.0500 & 0.0546 & 0.0578 & 0.0611 & 0.0642 & 0.0669 & 0.0689\end{array}$ $\begin{array}{lllllllllll}0.0716 & 0.0736 & 0.0756 & 0.0774 & 0.0801 & 0.0870 & 0.0970 & 0.1044\end{array}$ $\begin{array}{llllllllll}0.1113 & 0.1162 & 0.1209 & 0.1242 & 0.1269 & 0.1291 & 0.1307 & 0.1320\end{array}$

$\begin{array}{lllllllllll}\text { EH } & 0.0000 & 0.0002 & 0.0002 & 0.0002 & 0.0022 & 0.0076 & 0.0272 & 0.0445\end{array}$ $\begin{array}{lllllllllll}0.0583 & 0.0678 & 0.0730 & 0.0765 & 0.0797 & 0.0823 & 0.0842 & 0.0864\end{array}$ $\begin{array}{lllllllllll}0.0883 & 0.0903 & 0.0924 & 0.0946 & 0.0974 & 0.1009 & 0.1089 & 0.1169\end{array}$ $\begin{array}{lllllllll}0.1229 & 0.1277 & 0.1320 & 0.1350 & 0.1374 & 0.1395 & 0.1406 & 0.1421\end{array}$

$\begin{array}{llllllllll}\text { EJ } & 0.0007 & 0.0007 & 0.0007 & 0.0009 & 0.0013 & 0.0040 & 0.0150 & 0.0293\end{array}$ $\begin{array}{lllllllllll}0.0407 & 0.0477 & 0.0519 & 0.0557 & 0.0585 & 0.0603 & 0.0645 & 0.0682\end{array}$ $\begin{array}{llllllllll}0.0719 & 0.0748 & 0.0777 & 0.0807 & 0.0838 & 0.0876 & 0.0931 & 0.1014\end{array}$ $\begin{array}{lllllllll}0.1085 & 0.1142 & 0.1186 & 0.1217 & 0.1236 & 0.1247 & 0.1254 & 0.1256\end{array}$

$\begin{array}{llllllllll}\text { EK } & 0.0000 & 0.0000 & 0.0002 & 0.0002 & 0.0009 & 0.0066 & 0.0142 & 0.0276\end{array}$ $\begin{array}{llllllllll}0.0425 & 0.0534 & 0.0598 & 0.0644 & 0.0688 & 0.0723 & 0.0753 & 0.0782\end{array}$ $\begin{array}{llllllllll}0.0810 & 0.0841 & 0.0869 & 0.0900 & 0.0933 & 0.0975 & 0.1029 & 0.1110\end{array}$ $\begin{array}{lllllllll}0.1191 & 0.1250 & 0.1294 & 0.1327 & 0.1353 & 0.1371 & 0.1384 & 0.1395\end{array}$ 
Table A5b (Continued)

ID Cumulative Volumetric Porosity $\left(\mathrm{m}^{3} / \mathrm{m}^{3}\right)$ for Data in Table A5a

EM $\quad \begin{array}{llllllllll}0.0000 & 0.0002 & 0.0002 & 0.0007 & 0.0027 & 0.0081 & 0.0160 & 0.0254\end{array}$

$\begin{array}{llllllllll}0.0349 & 0.0428 & 0.0504 & 0.0547 & 0.0580 & 0.0610 & 0.0637 & 0.0662\end{array}$

$\begin{array}{llllllllll}0.0686 & 0.0711 & 0.0736 & 0.0765 & 0.0792 & 0.0824 & 0.0869 & 0.0934\end{array}$

$\begin{array}{llllllllll}0.1006 & 0.1069 & 0.1111 & 0.1143 & 0.1168 & 0.1192 & 0.1208 & 0.1222\end{array}$

EN $\quad \begin{array}{lllllllll}0.0000 & 0.0000 & 0.0000 & 0.0000 & 0.0017 & 0.0082 & 0.0205 & 0.0344\end{array}$ $\begin{array}{lllllllll}0.0538 & 0.0669 & 0.0734 & 0.0787 & 0.0829 & 0.0861 & 0.0890 & 0.0918\end{array}$ $\begin{array}{lllllllll}0.0945 & 0.0973 & 0.1002 & 0.1034 & 0.1066 & 0.1108 & 0.1171 & 0.1277\end{array}$ $\begin{array}{llllllll}0.1380 & 0.1464 & 0.1519 & 0.1555 & 0.1583 & 0.1602 & 0.1616 & 0.1629\end{array}$

EP

$\begin{array}{lllllllll}0.0000 & 0.0002 & 0.0002 & 0.0006 & 0.0017 & 0.0050 & 0.0118 & 0.0283\end{array}$

$\begin{array}{llllllllll}0.0573 & 0.0775 & 0.0876 & 0.0941 & 0.0991 & 0.1029 & 0.1065 & 0.1100\end{array}$

$\begin{array}{llllllllll}0.1132 & 0.1163 & 0.1197 & 0.1231 & 0.1273 & 0.1321 & 0.1388 & 0.1470\end{array}$

$\begin{array}{lllllllll}0.1546 & 0.1613 & 0.1655 & 0.1682 & 0.1703 & 0.1720 & 0.1733 & 0.1741\end{array}$

$\begin{array}{llllllllll}\text { ER } & 0.0000 & 0.0000 & 0.0000 & 0.0000 & 0.0015 & 0.0059 & 0.0153 & 0.0331\end{array}$

$\begin{array}{llllllllll}0.0506 & 0.0622 & 0.0683 & 0.0736 & 0.0777 & 0.0815 & 0.0848 & 0.0878\end{array}$

$\begin{array}{lllllllll}0.0907 & 0.0937 & 0.0964 & 0.0996 & 0.1029 & 0.1071 & 0.1128 & 0.1204\end{array}$

$\begin{array}{llllllll}0.1294 & 0.1373 & 0.1437 & 0.1472 & 0.1500 & 0.1520 & 0.1537\end{array}$

ES

$\begin{array}{lllllllll}0.0000 & 0.0000 & 0.0002 & 0.0004 & 0.0004 & 0.0013 & 0.0045 & 0.0112\end{array}$

$\begin{array}{lllllllllll}0.0312 & 0.0432 & 0.0503 \cdot & 0.0570 & 0.0621 & 0.0667 & 0.0714 & 0.0761\end{array}$

$\begin{array}{llllllllll}0.0802 & 0.0828 & 0.0854 & 0.0877 & 0.0920 & 0.0983 & 0.1058 & 0.1137\end{array}$

$\begin{array}{lllllllll}0.1234 & 0.1312 & 0.1367 & 0.1406 & 0.1434 & 0.1456 & 0.1469 & 0.1484\end{array}$

ET

$\begin{array}{lllllllll}0.0000 & 0.0000 & 0.0000 & 0.0002 & 0.0011 & 0.0057 & 0.0120 & 0.0217\end{array}$

$\begin{array}{llllllllll}0.0428 & 0.0563 & 0.0627 & 0.0679 & 0.0726 & 0.0760 & 0.0779 & 0.0795\end{array}$

$\begin{array}{lllllllll}0.0829 & 0.0893 & 0.0924 & 0.0960 & 0.0996 & 0.1015 & 0.1066 & 0.1196\end{array}$

$\begin{array}{llllllll}0.1287 & 0.1369 & 0.1431 & 0.1467 & 0.1490 & 0.1506 & 0.1521 & 0.1530\end{array}$

$\begin{array}{llllllllllllllllll}\text { Y1 } & \text { GB } & 0.0000 & 0.0002 & 0.0002 & 0.0006 & 0.0034 & 0.0129 & 0.0257 & 0.0343\end{array}$

$\begin{array}{llllllllll}0.0394 & 0.0430 & 0.0460 & 0.0496 & 0.0534 & 0.0562 & 0.0585 & 0.0608\end{array}$

$\begin{array}{lllllllllll}0.0632 & 0.0659 & 0.0685 & 0.0721 & 0.0772 & 0.0886 & 0.0992 & 0.1079\end{array}$

$\begin{array}{llllllllll}0.1149 & 0.1208 & 0.1255 & 0.1293 & 0.1321 & 0.1344 & 0.1361 & 0.1374\end{array}$

GC $\quad \begin{array}{llllllllll}0.0000 & 0.0002 & 0.0002 & 0.0009 & 0.0024 & 0.0071 & 0.0174 & 0.0258\end{array}$

$\begin{array}{llllllll}0.0306 & 0.0336 & 0.0366 & 0.0394 & 0.0422 & 0.0448 & 0.0469 & 0.0495\end{array}$

$\begin{array}{lllllllll}0.0516 & 0.0538 & 0.0564 & 0.0592 & 0.0626 & 0.0708 & 0.0805 & 0.0887\end{array}$

$\begin{array}{llllllll}0.0951 & 0.1016 & 0.1061 & 0.1100 & 0.1134 & 0.1158 & 0.1175 & 0.1188\end{array}$

GD

$\begin{array}{lllllllll}- & 0.0000 & 0.0000 & 0.0002 & 0.0036 & 0.0086 & 0.0156 & 0.0248\end{array}$

$\begin{array}{llllllllll}0.0310 & 0.0353 & 0.0396 & 0.0439 & 0.0484 & 0.0527 & 0.0561 & 0.0589\end{array}$

$\begin{array}{llllllllll}0.0612 & 0.0642 & 0.0664 & 0.0693 & 0.0728 & 0.0792 & 0.0916 & 0.1008\end{array}$

$\begin{array}{lllllllll}0.1077 & 0.1137 & 0.1190 & 0.1229 & 0.1263 & 0.1286 & 0.1310 & 0.1325\end{array}$

GA $\quad \begin{array}{llllllllll}0.0000 & 0.0000 & 0.0008 & 0.0050 & 0.0161 & 0.0256 & 0.0337 & 0.0402\end{array}$

$\begin{array}{llllllllll}0.0448 & 0.0488 & 0.0528 & 0.0566 & 0.0599 & 0.0633 & 0.0664 & 0.0696\end{array}$

$\begin{array}{lllllllll}0.0723 & 0.0750 & 0.0779 & 0.0811 & 0.0847 & 0.0895 & 0.0983 & 0.1081\end{array}$

$\begin{array}{llllllll}0.1157 & 0.1219 & 0.1274 & 0.1310 & 0.1337 & 0.1360 & 0.1375 & 0.1389\end{array}$ 
Table A5b (Continued)

ID Cumulative Volumetric Porosity $\left(\mathrm{m}^{3} / \mathrm{m}^{3}\right)$ for Data in Table $\mathrm{A} 5 \mathrm{a}$

GF $\quad \begin{array}{llllllllll}0.0000 & 0.0000 & 0.0013 & 0.0091 & 0.0279 & 0.0447 & 0.0580 & 0.0684\end{array}$

$\begin{array}{lllllllll}0.0762 & 0.0814 & 0.0867 & 0.0918 & 0.0960 & 0.0992 & 0.1021 & 0.1047\end{array}$

$\begin{array}{lllllllll}0.1074 & 0.1099 & 0.1125 & 0.1154 & 0.1190 & 0.1234 & 0.1312 & 0.1401\end{array}$

$\begin{array}{lllllllll}0.1471 & 0.1525 & 0.1568 & 0.1597 & 0.1618 & 0.1637 & 0.1652 & 0.1658\end{array}$

GG $\quad \begin{array}{lllllllll}0.0000 & 0.0000 & 0.0002 & 0.0017 & 0.0094 & 0.0224 & 0.0343 & 0.0464\end{array}$ $\begin{array}{llllllllll}0.0573 & 0.0665 & 0.0739 & 0.0812 & 0.0880 & 0.0937 & 0.0988 & 0.1042\end{array}$

$\begin{array}{llllllllll}0.1088 & 0.1127 & 0.1163 & 0.1199 & 0.1233 & 0.1272 & 0.1314 & 0.1370\end{array}$

$\begin{array}{llllllll}0.1423 & 0.1472 & 0.1506 & 0.1532 & 0.1555 & 0.1570 & 0.1583 & 0.1591\end{array}$

$\begin{array}{lllllllllll}\mathrm{GH} & 0.0002 & 0.0002 & 0.0004 & 0.0011 & 0.0046 & 0.0122 & 0.0243 & 0.0315\end{array}$ $\begin{array}{llllllllll}0.0393 & 0.0480 & 0.0571 & 0.0644 & 0.0707 & 0.0764 & 0.0801 & 0.0840\end{array}$ $\begin{array}{lllllllll}0.0872 & 0.0905 & 0.0935 & 0.0963 & 0.0994 & 0.1035 & 0.1081 & 0.1152\end{array}$ $\begin{array}{lllllllll}0.1217 & 0.1278 & 0.1317 & 0.1345 & 0.1369 & 0.1389 & 0.1404 & 0.1410\end{array}$

$\begin{array}{llllllllllllllll}\mathrm{Y} 2 & \mathrm{JB} & & 0.0000 & 0.0004 & 0.0010 & 0.0040 & 0.0137 & 0.0224 & 0.0307 & 0.0384\end{array}$ $\begin{array}{lllllllll}0.0454 & 0.0499 & 0.0533 & 0.0558 & 0.0584 & 0.0612 & 0.0632 & 0.0657\end{array}$ $\begin{array}{llllllllll}0.0685 & 0.0723 & 0.0806 & 0.0937 & 0.1060 & 0.1170 & 0.1265 & 0.1349\end{array}$ $\begin{array}{lllllllll}0.1418 & 0.1475 & 0.1521 & 0.1559 & 0.1596 & 0.1624 & 0.1642 & 0.1660\end{array}$

JC $\quad \begin{array}{llllllllll}0.0000 & 0.0002 & 0.0004 & 0.0007 & 0.0014 & 0.0018 & 0.0029 & 0.0049\end{array}$ $\begin{array}{lllllllll}0.0094 & 0.0135 & 0.0176 & 0.0223 & 0.0268 & 0.0311 & 0.0342 & 0.0373\end{array}$ $\begin{array}{lllllllll}0.0414 & 0.0472 & 0.0571 & 0.0689 & 0.0787 & 0.0869 & 0.0936 & 0.0992\end{array}$ $\begin{array}{lllllllll}0.1040 & 0.1082 & 0.1116 & 0.1147 & 0.1179 & 0.1197 & 0.1213 & 0.1222\end{array}$

JD $\quad \begin{array}{lllllllll}0.0000 & 0.0000 & 0.0000 & 0.0000 & 0.0000 & 0.0038 & 0.0108 & 0.0155\end{array}$ $\begin{array}{llllllllll}0.0197 & 0.0221 & 0.0252 & 0.0274 & 0.0303 & 0.0331 & 0.0362 & 0.0389\end{array}$ $\begin{array}{llllllllll}0.0415 & 0.0442 & 0.0473 & 0.0517 & 0.0603 & 0.0683 & 0.0754 & 0.0818\end{array}$ $\begin{array}{llllllll}0.0899 & 0.0997 & 0.1039 & 0.1074 & 0.1233 & 0.1268 & 0.1295 & 0.1315\end{array}$

JE $\quad-\quad 0.0000 \quad 0.0000 \quad 0.0000 \quad 0.0000 \quad 0.0000 \quad 0.0000 \quad 0.0006$ $\begin{array}{llllllllll}0.0047 & 0.0081 & 0.0104 & 0.0125 & 0.0157 & 0.0178 & 0.0199 & 0.0220\end{array}$ $\begin{array}{lllllllll}0.0242 & 0.0261 & 0.0280 & 0.0301 & 0.0335 & 0.0394 & 0.0454 & 0.0500\end{array}$ $\begin{array}{llllllllll}0.0541 & 0.0581 & 0.0668 & 0.0897 & 0.1187 & 0.1836 & 0.1866 & 0.1887\end{array}$

JF

$\begin{array}{lllllllll}0.0000 & 0.0000 & 0.0044 & 0.0109 & 0.0212 & 0.0309 & 0.0397 & 0.0470\end{array}$ $\begin{array}{llllllllll}0.0525 & 0.0569 & 0.0603 & 0.0636 & 0.0670 & 0.0706 & 0.0739 & 0.0773\end{array}$ $\begin{array}{lllllllllll}0.0808 & 0.0842 & 0.0880 & 0.0916 & 0.0956 & 0.1002 & 0.1042 & 0.1084\end{array}$ $\begin{array}{lllllllll}0.1121 & 0.1159 & 0.1193 & 0.1218 & 0.1243 & 0.1260 & 0.1270 & 0.1279\end{array}$

JG $\quad \begin{array}{lllllllll}0.0000 & 0.0000 & 0.0004 & 0.0040 & 0.0115 & 0.0234 & 0.0354 & 0.0432\end{array}$ $\begin{array}{llllllllll}0.0498 & 0.0547 & 0.0599 & 0.0645 & 0.0692 & 0.0731 & 0.0765 & 0.0799\end{array}$ $\begin{array}{lllllllll}0.0831 & 0.0861 & 0.0892 & 0.0927 & 0.0969 & 0.1022 & 0.1114 & 0.1199\end{array}$ $\begin{array}{llllllllll}0.1269 & 0.1327 & 0.1374 & 0.1410 & 0.1440 & 0.1463 & 0.1480 & 0.1491\end{array}$

$\mathrm{JH}$

$\begin{array}{lllllllll}0.0000 & 0.0000 & 0.0002 & 0.0013 & 0.0089 & 0.0224 & 0.0369 & 0.0462\end{array}$ $\begin{array}{lllllllll}0.0561 & 0.0637 & 0.0692 & 0.0745 & 0.0798 & 0.0838 & 0.0871 & 0.0903\end{array}$ $\begin{array}{lllllllll}0.0935 & 0.0964 & 0.0992 & 0.1028 & 0.1066 & 0.1133 & 0.1230 & 0.1314\end{array}$ $\begin{array}{lllllllll}0.1382 & 0.1441 & 0.1492 & 0.1521 & 0.1547 & 0.1568 & 0.1578 & 0.1589\end{array}$ 
Table A5b (Continued)

ID Cumulative Volumetric Porosity $\left(\mathrm{m}^{3} / \mathrm{m}^{3}\right)$ for Data in Table A5a

$\begin{array}{llllllllll}\text { JJ } & 0.0000 & 0.0000 & 0.0015 & 0.0048 & 0.0115 & 0.0228 & 0.0375 & 0.0488\end{array}$ $\begin{array}{lllllllllll}0.0575 & 0.0621 & 0.0651 & 0.0681 & 0.0707 & 0.0727 & 0.0749 & 0.0766\end{array}$ $\begin{array}{lllllllll}0.0788 & 0.0807 & 0.0829 & 0.0848 & 0.0877 & 0.0920 & 0.0996 & 0.1070\end{array}$ $\begin{array}{lllllllll}0.1146 & 0.1213 & 0.1267 & 0.1298 & 0.1326 & 0.1348 & 0.1363 & 0.1371\end{array}$

$\begin{array}{llllllllll}\text { JK } & & 0.0000 & 0.0000 & 0.0015 & 0.0045 & 0.0113 & 0.0268 & 0.0402 & 0.0529\end{array}$ $\begin{array}{llllllllll}0.0678 & 0.0790 & 0.0850 & 0.0905 & 0.0950 & 0.0987 & 0.1016 & 0.1044\end{array}$ $\begin{array}{lllllllll}0.1072 & 0.1094 & 0.1119 & 0.1143 & 0.1175 & 0.1220 & 0.1282 & 0.1348\end{array}$ $\begin{array}{lllllllll}0.1400 & 0.1449 & 0.1496 & 0.1528 & 0.1556 & 0.1575 & 0.1588 & 0.1596\end{array}$

JM $\quad \begin{array}{llllllllll}0.0000 & 0.0002 & 0.0006 & 0.0021 & 0.0081 & 0.0184 & 0.0346 & 0.0530\end{array}$ $\begin{array}{llllllllll}0.0683 & 0.0764 & 0.0811 & 0.0853 & 0.0892 & 0.0923 & 0.0948 & 0.0975\end{array}$ $\begin{array}{lllllllll}0.1002 & 0.1029 & 0.1058 & 0.1089 & 0.1130 & 0.1194 & 0.1300 & 0.1397\end{array}$ $\begin{array}{lllllllll}0.1493 & 0.1569 & 0.1623 & 0.1660 & 0.1687 & 0.1708 & 0.1722 & 0.1733\end{array}$

$\begin{array}{llllllllll}\text { JN } & \quad 0.0000 & 0.0000 & 0.0000 & 0.0002 & 0.0006 & 0.0052 & 0.0230 & 0.0424\end{array}$ $\begin{array}{llllllllll}0.0591 & 0.0712 & 0.0789 & 0.0847 & 0.0899 & 0.0937 & 0.0970 & 0.1002\end{array}$ $\begin{array}{llllllllll}0.1028 & 0.1056 & 0.1081 & 0.1109 & 0.1144 & 0.1189 & 0.1262 & 0.1346\end{array}$ $\begin{array}{lllllllll}0.1421 & 0.1492 & 0.1546 & 0.1587 & 0.1610 & 0.1632 & 0.1645 & 0.1658\end{array}$

$\begin{array}{llllllllll}\text { JP } & \quad & 0.0000 & 0.0007 & 0.0018 & 0.0028 & 0.0070 & 0.0120 & 0.0204 & 0.0276\end{array}$ $\begin{array}{llllllllll}0.0335 & 0.0383 & 0.0425 & 0.0464 & 0.0510 & 0.0565 & 0.0609 & 0.0655\end{array}$ $\begin{array}{lllllllll}0.0692 & 0.0723 & 0.0756 & 0.0791 & 0.0839 & 0.0907 & 0.0970 & 0.1025\end{array}$ $\begin{array}{llllllllll}0.1073 & 0.1110 & 0.1141 & 0.1165 & 0.1189 & 0.1204 & 0.1220 & 0.1229\end{array}$

$\begin{array}{lllllllllllllllll}\text { Y3 } & \text { MB } & - & 0.0002 & 0.0002 & 0.0002 & 0.0002 & 0.0002 & 0.0002 & 0.0002\end{array}$ $\begin{array}{lllllllll}0.0012 & 0.0012 & 0.0020 & 0.0036 & 0.0058 & 0.0076 & 0.0096 & 0.0117\end{array}$ $\begin{array}{llllllllll}0.0141 & 0.0169 & 0.0205 & 0.0271 & 0.0342 & 0.0410 & 0.0464 & 0.0519\end{array}$ $\begin{array}{lllllllll}0.0553 & 0.0585 & 0.0647 & 0.0967 & 0.1351 & 0.1387 & 0.1413 & 0.1427\end{array}$

MC $\quad \begin{array}{lllllllll}0.0000 & 0.0000 & 0.0000 & 0.0000 & 0.0000 & 0.0000 & 0.0000 & 0.0000\end{array}$ $\begin{array}{llllllllll}0.0000 & 0.0000 & 0.0000 & 0.0000 & 0.0000 & 0.0006 & 0.0019 & 0.0029\end{array}$ $\begin{array}{lllllllll}0.0043 & 0.0058 & 0.0076 & 0.0107 & 0.0149 & 0.0196 & 0.0239 & 0.0287\end{array}$ $\begin{array}{lllllllll}0.0345 & 0.0398 & 0.0535 & 0.0759 & 0.0890 & 0.1053 & 0.1368 & 0.1492\end{array}$

MD

$\begin{array}{llllllll}0.0000 & 0.0000 & 0.0000 & 0.0000 & 0.0000 & 0.0000 & 0.0000 & 0.0000\end{array}$ $\begin{array}{llllllllll}0.0000 & 0.0004 & 0.0032 & 0.0060 & 0.0090 & 0.0114 & 0.0133 & 0.0163\end{array}$ $\begin{array}{lllllllllll}0.0196 & 0.0230 & 0.0271 & 0.0338 & 0.0426 & 0.0501 & 0.0563 & 0.0624\end{array}$ $\begin{array}{llllllllll}0.0684 & 0.0761 & 0.1060 & 0.1503 & 0.2023 & 0.2064 & 0.2092 & 0.2113\end{array}$

ME $\quad \begin{array}{llllllllll}0.0000 & 0.0002 & 0.0002 & 0.0013 & 0.0101 & 0.0228 & 0.0327 & 0.0389\end{array}$ $\begin{array}{lllllllll}0.0449 & 0.0494 & 0.0540 & 0.0578 & 0.0615 & 0.0656 & 0.0694 & 0.0737\end{array}$ $\begin{array}{lllllllll}0.0774 & 0.0815 & 0.0856 & 0.0914 & 0.1006 & 0.1103 & 0.1178 & 0.1243\end{array}$ $\begin{array}{lllllllll}0.1294 & 0.1333 & 0.1365 & 0.1393 & 0.1417 & 0.1434 & 0.1449 & 0.1462\end{array}$

MF

$\begin{array}{lllllllll}0.0004 & 0.0004 & 0.0006 & 0.0011 & 0.0032 & 0.0060 & 0.0129 & 0.0254\end{array}$ $\begin{array}{llllllllll}0.0426 & 0.0583 & 0.0658 & 0.0720 & 0.0780 & 0.0830 & 0.0873 & 0.0914\end{array}$ $\begin{array}{lllllllll}0.0950 & 0.0991 & 0.1026 & 0.1064 & 0.1109 & 0.1159 & 0.1223 & 0.1316\end{array}$ $\begin{array}{lllllllll}0.1404 & 0.1481 & 0.1535 & 0.1567 & 0.1593 & 0.1615 & 0.1625 & 0.1638\end{array}$ 
Table A5b (Continued)

ID Cumulative Volumetric Porosity $\left(\mathrm{m}^{3} / \mathrm{m}^{3}\right)$ for Data in Table A5a

MG $\quad \begin{array}{lllllllll}0.0000 & 0.0000 & 0.0010 & 0.0050 & 0.0156 & 0.0273 & 0.0378 & 0.0467\end{array}$ $\begin{array}{lllllllll}0.0543 & 0.0600 & 0.0659 & 0.0709 & 0.0768 & 0.0816 & 0.0859 & 0.0903\end{array}$ $\begin{array}{lllllllll}0.0947 & 0.0998 & 0.1048 & 0.1117 & 0.1194 & 0.1279 & 0.1362 & 0.1442\end{array}$ $\begin{array}{lllllllll}0.1507 & 0.1566 & 0.1620 & 0.1656 & 0.1683 & 0.1703 & 0.1719 & 0.1729\end{array}$

MH $\quad \begin{array}{lllllllll}0.0000 & 0.0002 & 0.0004 & 0.0011 & 0.0072 & 0.0150 & 0.0257 & 0.0373\end{array}$ $\begin{array}{lllllllll}0.0475 & 0.0532 & 0.0582 & 0.0627 & 0.0665 & 0.0694 & 0.0720 & 0.0747\end{array}$ $\begin{array}{lllllllll}0.0772 & 0.0795 & 0.0821 & 0.0855 & 0.0901 & 0.0987 & 0.1095 & 0.1177\end{array}$ $\begin{array}{lllllllll}0.1247 & 0.1304 & 0.1348 & 0.1382 & 0.1409 & 0.1431 & 0.1445 & 0.1458\end{array}$

MJ $\quad \begin{array}{llllllllll}0.0000 & 0.0000 & 0.0002 & 0.0002 & 0.0009 & 0.0027 & 0.0111 & 0.0317\end{array}$ $\begin{array}{llllllllll}0.0426 & 0.0511 & 0.0584 & 0.0642 & 0.0682 & 0.0718 & 0.0745 & 0.0769\end{array}$ $\begin{array}{lllllllll}0.0794 & 0.0818 & 0.0836 & 0.0861 & 0.0888 & 0.0919 & 0.0970 & 0.1032\end{array}$ $\begin{array}{lllllllll}0.1084 & 0.1126 & 0.1164 & 0.1193 & 0.1218 & 0.1235 & 0.1249 & 0.1258\end{array}$

MK $\quad \begin{array}{lllllllll}0.0020 & 0.0020 & 0.0020 & 0.0025 & 0.0032 & 0.0047 & 0.0065 & 0.0106\end{array}$ $\begin{array}{llllllllll}0.0184 & 0.0335 & 0.0486 & 0.0549 & 0.0608 & 0.0655 & 0.0693 & 0.0729\end{array}$ $\begin{array}{lllllllll}0.0765 & 0.0801 & 0.0828 & 0.0857 & 0.0889 & 0.0922 & 0.0958 & 0.1001\end{array}$ $\begin{array}{lllllllll}0.1049 & 0.1087 & 0.1118 & 0.1141 & 0.1161 & 0.1172 & 0.1185 & 0.1192\end{array}$

MM $\quad \begin{array}{lllllllll}0.0000 & 0.0000 & 0.0000 & 0.0004 & 0.0016 & 0.0038 & 0.0109 & 0.0223\end{array}$ $\begin{array}{llllllllll}0.0368 & 0.0475 & 0.0569 & 0.0631 & 0.0682 & 0.0723 & 0.0754 & 0.0785\end{array}$ $\begin{array}{llllllllll}0.0812 & 0.0847 & 0.0870 & 0.0903 & 0.0941 & 0.0981 & 0.1035 & 0.1104\end{array}$ $\begin{array}{lllllllll}0.1164 & 0.1218 & 0.1260 & 0.1289 & 0.1316 & 0.1333 & 0.1349 & 0.1360\end{array}$

MN $\quad \begin{array}{lllllllll}0.0002 & 0.0004 & 0.0004 & 0.0004 & 0.0015 & 0.0037 & 0.0114 & 0.0216\end{array}$ $\begin{array}{lllllllll}0.0385 & 0.0530 & 0.0631 & 0.0708 & 0.0768 & 0.0823 & 0.0856 & 0.0895\end{array}$ $\begin{array}{lllllllll}0.0933 & 0.0968 & 0.0999 & 0.1034 & 0.1069 & 0.1109 & 0.1162 & 0.1232\end{array}$ $\begin{array}{lllllllll}0.1300 & 0.1351 & 0.1390 & 0.1421 & 0.1443 & 0.1459 & 0.1472 & 0.1485\end{array}$

MP $\quad \begin{array}{llllllllll}0.0000 & 0.0000 & 0.0000 & 0.0000 & 0.0013 & 0.0054 & 0.0177 & 0.0313\end{array}$ $\begin{array}{llllllllll}0.0462 & 0.0583 & 0.0652 & 0.0713 & 0.0771 & 0.0819 & 0.0855 & 0.0890\end{array}$ $\begin{array}{llllllllll}0.0922 & 0.0957 & 0.0987 & 0.1022 & 0.1061 & 0.1108 & 0.1171 & 0.1266\end{array}$ $\begin{array}{lllllllll}0.1352 & 0.1410 & 0.1454 & 0.1484 & 0.1508 & 0.1525 & 0.1538 & 0.1549\end{array}$

$\begin{array}{llllllllll}M R & 0.0000 & 0.0002 & 0.0002 & 0.0004 & 0.0022 & 0.0048 & 0.0118 & 0.0278\end{array}$ $\begin{array}{llllllllll}0.0473 & 0.0593 & 0.0675 & 0.0738 & 0.0797 & 0.0845 & 0.0878 & 0.0915\end{array}$ $\begin{array}{lllllllll}0.0950 & 0.0985 & 0.1018 & 0.1053 & 0.1093 & 0.1137 & 0.1194 & 0.1277\end{array}$ $\begin{array}{llllllll}0.1364 & 0.1430 & 0.1474 & 0.1505 & 0.1526 & 0.1546 & 0.1557 & 0.1568\end{array}$

MS $\quad \begin{array}{llllllllll}0.0000 & 0.0000 & 0.0002 & 0.0004 & 0.0010 & 0.0027 & 0.0107 & 0.0304\end{array}$ $\begin{array}{llllllllll}0.0510 & 0.0662 & 0.0746 & 0.0846 & 0.0909 & 0.0962 & 0.1006 & 0.1046\end{array}$ $\begin{array}{llllllllll}0.1094 & 0.1132 & 0.1163 & 0.1201 & 0.1237 & 0.1283 & 0.1355 & 0.1449\end{array}$ $\begin{array}{llllllllll}0.1535 & 0.1590 & 0.1634 & 0.1659 & 0.1682 & 0.1697 & 0.1709 & 0.1720\end{array}$

$\begin{array}{llllllllll}\text { MT } & 0.0000 & 0.0002 & 0.0002 & 0.0002 & 0.0006 & 0.0015 & 0.0033 & 0.0107\end{array}$ $\begin{array}{llllllllll}0.0376 & 0.0623 & 0.0767 & 0.0897 & 0.0993 & 0.1058 & 0.1101 & 0.1173\end{array}$ $\begin{array}{llllllllll}0.1218 & 0.1254 & 0.1283 & 0.1346 & 0.1394 & 0.1440 & 0.1503 & 0.1582\end{array}$ $\begin{array}{lllllllll}0.1651 & 0.1699 & 0.1733 & 0.1756 & 0.1777 & 0.1787 & 0.1799 \cdot 0.1812\end{array}$ 
ID Cumulative Volumetric Porosity $\left(\mathrm{m}^{3} / \mathrm{m}^{3}\right)$ for Data in Table A5a

MU $\quad \begin{array}{lllllllll}0.0000 & 0.0000 & 0.0000 & 0.0000 & 0.0002 & 0.0004 & 0.0032 & 0.0153\end{array}$ $\begin{array}{lllllllll}0.0320 & 0.0428 & 0.0522 & 0.0608 & 0.0673 & 0.0727 & 0.0774 & 0.0817\end{array}$ $\begin{array}{lllllllll}0.0860 & 0.0903 & 0.0944 & 0.0985 & 0.1032 & 0.1084 & 0.1152 & 0.1243\end{array}$ $\begin{array}{lllllllll}0.1337 & 0.1408 & 0.1453 & 0.1486 & 0.1509 & 0.1531 & 0.1544 & 0.1557\end{array}$

$\begin{array}{llllllllllll}21 & \text { PB } & 0.0000 & 0.0000 & 0.0000 & 0.0000 & 0.0030 & 0.0086 & 0.0157 & 0.0230\end{array}$ $\begin{array}{llllllllll}0.0262 & 0.0292 & 0.0314 & 0.0333 & 0.0350 & 0.0370 & 0.0381 & 0.0398\end{array}$ $\begin{array}{lllllllll}0.0421 & 0.0456 & 0.0514 & 0.0617 & 0.0727 & 0.0817 & 0.0899 & 0.0970\end{array}$ $\begin{array}{llllllllll}0.1032 & 0.1084 & 0.1131 & 0.1168 & 0.1202 & 0.1232 & 0.1251 & 0.1268\end{array}$

PC $\quad \begin{array}{llllllllll}0.0000 & 0.0002 & 0.0008 & 0.0019 & 0.0087 & 0.0161 & 0.0236 & 0.0290\end{array}$ $\begin{array}{lllllllll}0.0342 & 0.0377 & 0.0404 & 0.0428 & 0.0443 & 0.0464 & 0.0480 & 0.0497\end{array}$ $\begin{array}{lllllllll}0.0524 & 0.0559 & 0.0609 & 0.0691 & 0.0795 & 0.0884 & 0.0956 & 0.1027\end{array}$ $\begin{array}{llllllll}0.1087 & 0.1138 & 0.1184 & 0.1223 & 0.1254 & 0.1281 & 0.1300 & 0.1319\end{array}$

PD $\quad \begin{array}{lllllllll}0.0000 & 0.0002 & 0.0004 & 0.0025 & 0.0072 & 0.0133 & 0.0238 & 0.0310\end{array}$ $\begin{array}{lllllllll}0.0371 & 0.0430 & 0.0465 & 0.0498 & 0.0529 & 0.0558 & 0.0584 & 0.0619\end{array}$ $\begin{array}{llllllllll}0.0656 & 0.0699 & 0.0761 & 0.0849 & 0.0961 & 0.1064 & 0.1156 & 0.1240\end{array}$ $\begin{array}{lllllllll}0.1314 & 0.1373 & 0.1425 & 0.1468 & 0.1503 & 0.1529 & 0.1550 & 0.1562\end{array}$

$\begin{array}{llllllllll}\mathrm{PE} & & 0.0000 & 0.0004 & 0.0008 & 0.0040 & 0.0078 & 0.0197 & 0.0271 & 0.0317\end{array}$ $\begin{array}{lllllllll}0.0365 & 0.0399 & 0.0428 & 0.0454 & 0.0477 & 0.0500 & 0.0525 & 0.0550\end{array}$ $\begin{array}{lllllllll}0.0580 & 0.0611 & 0.0653 & 0.0699 & 0.0762 & 0.0832 & 0.0895 & 0.0951\end{array}$ $\begin{array}{lllllllll}0.0995 & 0.1033 & 0.1065 & 0.1094 & 0.1117 & 0.1134 & 0.1147 & 0.1157\end{array}$

PF $\quad \begin{array}{llllllllll}0.0000 & 0.0000 & 0.0002 & 0.0009 & 0.0035 & 0.0077 & 0.0162 & 0.0261\end{array}$ $\begin{array}{llllllllll}0.0331 & 0.0379 & 0.0416 & 0.0436 & 0.0462 & 0.0495 & 0.0528 & 0.0558\end{array}$ $\begin{array}{llllllllll}0.0585 & 0.0611 & 0.0637 & 0.0666 & 0.0712 & 0.0793 & 0.0867 & 0.0929\end{array}$ $\begin{array}{llllllll}0.0975 & 0.1014 & 0.1045 & 0.1073 & 0.1093 & 0.1115 & 0.1128 & 0.1141\end{array}$

PG $\quad \begin{array}{llllllllll}0.0000 & 0.0002 & 0.0023 & 0.0053 & 0.0115 & 0.0192 & 0.0266 & 0.0339\end{array}$ $\begin{array}{lllllllll}0.0394 & 0.0439 & 0.0473 & 0.0501 & 0.0532 & 0.0567 & 0.0594 & 0.0628\end{array}$ $\begin{array}{lllllllll}0.0660 & 0.0692 & 0.0724 & 0.0756 & 0.0801 & 0.0852 & 0.0905 & 0.0958\end{array}$ $\begin{array}{lllllllll}0.0999 & 0.1037 & 0.1067 & 0.1097 & 0.1118 & 0.1140 & 0.1152 & 0.1165\end{array}$

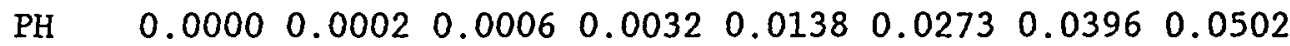
$\begin{array}{llllllllll}0.0594 & 0.0664 & 0.0721 & 0.0759 & 0.0799 & 0.0835 & 0.0865 & 0.0899\end{array}$ $\begin{array}{llllllllll}0.0924 & 0.0952 & 0.0979 & 0.1005 & 0.1047 & 0.1100 & 0.1183 & 0.1249\end{array}$ $\begin{array}{lllllllll}0.1297 & 0.1344 & 0.1378 & 0.1408 & 0.1431 & 0.1448 & 0.1461 & 0.1469\end{array}$

$\begin{array}{llllllllllllll}Z 2 & \text { SB } & 0.0000 & 0.0002 & 0.0004 & 0.0011 & 0.0050 & 0.0113 & 0.0198 & 0.0279\end{array}$ $\begin{array}{lllllllll}0.0331 & 0.0371 & 0.0395 & 0.0432 & 0.0464 & 0.0499 & 0.0530 & 0.0565\end{array}$ $\begin{array}{lllllllll}0.0597 & 0.0630 & 0.0667 & 0.0717 & 0.0817 & 0.0931 & 0.1018 & 0.1086\end{array}$ $\begin{array}{lllllllll}0.1147 & 0.1195 & 0.1236 & 0.1269 & 0.1302 & 0.1334 & 0.1358 & 0.1376\end{array}$

SC $\quad \begin{array}{llllllllll}0.0002 & 0.0004 & 0.0009 & 0.0022 & 0.0055 & 0.0108 & 0.0176 & 0.0240\end{array}$ $\begin{array}{lllllllll}0.0290 & 0.0326 & 0.0370 & 0.0416 & 0.0464 & 0.0513 & 0.0548 & 0.0581\end{array}$ $\begin{array}{llllllllll}0.0612 & 0.0640 & 0.0669 & 0.0706 & 0.0766 & 0.0860 & 0.0933 & 0.0997\end{array}$ $\begin{array}{lllllllll}0.1047 & 0.1091 & 0.1126 & 0.1159 & 0.1186 & 0.1210 & 0.1228 & 0.1241\end{array}$ 
ID Cumulative Volumetric Porosity $\left(\mathrm{m}^{3} / \mathrm{m}^{3}\right)$ for Data in Table A5a

SD $\quad \begin{array}{llllllllll}0.0000 & 0.0002 & 0.0058 & 0.0150 & 0.0250 & 0.0341 & 0.0420 & 0.0470\end{array}$ $\begin{array}{llllllllll}0.0516 & 0.0549 & 0.0578 & 0.0605 & 0.0641 & 0.0672 & 0.0699 & 0.0724\end{array}$ $\begin{array}{llllllllll}0.0757 & 0.0782 & 0.0807 & 0.0842 & 0.0880 & 0.0934 & 0.0988 & 0.1034\end{array}$ $\begin{array}{lllllllll}0.1080 & 0.1117 & 0.1156 & 0.1186 & 0.1213 & 0.1233 & 0.1250 & 0.1263\end{array}$

$\begin{array}{llllllllll}\text { SE } & 0.0000 & 0.0002 & 0.0002 & 0.0038 & 0.0108 & 0.0193 & 0.0259 & 0.0326\end{array}$ $\begin{array}{lllllllll}0.0367 & 0.0405 & 0.0443 & 0.0485 & 0.0528 & 0.0564 & 0.0600 & 0.0630\end{array}$ $\begin{array}{llllllllll}0.0664 & 0.0700 & 0.0738 & 0.0787 & 0.0861 & 0.0956 & 0.1054 & 0.1138\end{array}$ $\begin{array}{lllllllll}0.1208 & 0.1264 & 0.1310 & 0.1348 & 0.1378 & 0.1401 & 0.1420 & 0.1433\end{array}$

SF $\quad \begin{array}{lllllllll}0.0000 & 0.0000 & 0.0006 & 0.0033 & 0.0087 & 0.0208 & 0.0356 & 0.0428\end{array}$ $\begin{array}{lllllllll}0.0466 & 0.0490 & 0.0556 & 0.0634 & 0.0702 & 0.0766 & 0.0824 & 0.0875\end{array}$ $\begin{array}{llllllllll}0.0929 & 0.0976 & 0.1032 & 0.1098 & 0.1197 & 0.1294 & 0.1378 & 0.1452\end{array}$ $\begin{array}{lllllllll}0.1508 & 0.1555 & 0.1594 & 0.1621 & 0.1648 & 0.1666 & 0.1679 & 0.1691\end{array}$

SG $\quad \begin{array}{lllllllll}0.0000 & 0.0002 & 0.0004 & 0.0006 & 0.0012 & 0.0021 & 0.0070 & 0.0156\end{array}$ $\begin{array}{llllllllll}0.0220 & 0.0263 & 0.0304 & 0.0345 & 0.0388 & 0.0415 & 0.0443 & 0.0476\end{array}$ $\begin{array}{lllllllllll}0.0503 & 0.0532 & 0.0565 & 0.0616 & 0.0694 & 0.0778 & 0.0862 & 0.0932\end{array}$ $\begin{array}{llllllllll}0.0998 & 0.1053 & 0.1102 & 0.1137 & 0.1168 & 0.1190 & 0.1209 & 0.1221\end{array}$

SH $\quad \begin{array}{llllllllll}0.0002 & 0.0008 & 0.0008 & 0.0010 & 0.0024 & 0.0130 & 0.0244 & 0.0333\end{array}$ $\begin{array}{lllllllll}0.0428 & 0.0469 & 0.0510 & 0.0566 & 0.0615 & 0.0639 & 0.0664 & 0.0692\end{array}$ $\begin{array}{llllllllll}0.0735 & 0.0757 & 0.0782 & 0.0820 & 0.0865 & 0.0983 & 0.1068 & 0.1137\end{array}$ $\begin{array}{lllllllll}0.1206 & 0.1263 & 0.1305 & 0.1330 & 0.1358 & 0.1382 & 0.1399 & 0.1407\end{array}$

$\begin{array}{lllllllll}\text { SJ } & 0.0000 & 0.0002 & 0.0004 & 0.0010 & 0.0034 & 0.0120 & 0.0265 & 0.0391\end{array}$ $\begin{array}{llllllllll}0.0512 & 0.0590 & 0.0653 & 0.0706 & 0.0754 & 0.0790 & 0.0817 & 0.0844\end{array}$ $\begin{array}{llllllllll}0.0869 & 0.0895 & 0.0918 & 0.0947 & 0.0976 & 0.1023 & 0.1098 & 0.1165\end{array}$ $\begin{array}{lllllllll}0.1218 & 0.1262 & 0.1300 & 0.1327 & 0.1352 & 0.1367 & 0.1380 & 0.1392\end{array}$

SK $\quad \begin{array}{lllllllll}0.0000 & 0.0004 & 0.0004 & 0.0004 & 0.0006 & 0.0019 & 0.0204 & 0.0288\end{array}$ $\begin{array}{llllllllll}0.0433 & 0.0519 & 0.0584 & 0.0636 & 0.0668 & 0.0701 & 0.0727 & 0.0756\end{array}$ $\begin{array}{llllllllll}0.0787 & 0.0811 & 0.0834 & 0.0861 & 0.0888 & 0.0922 & 0.0970 & 0.1040\end{array}$ $\begin{array}{llllllll}0.1113 & 0.1161 & 0.1197 & 0.1222 & 0.1243 & 0.1262 & 0.1270 & 0.1277\end{array}$

SM $\quad \begin{array}{lllllllll}0.0000 & 0.0002 & 0.0002 & 0.0002 & 0.0022 & 0.0106 & 0.0219 & 0.0304\end{array}$ $\begin{array}{llllllllll}0.0393 & 0.0480 & 0.0562 & 0.0631 & 0.0679 & 0.0723 & 0.0753 & 0.0779\end{array}$ $\begin{array}{lllllllll}0.0805 & 0.0831 & 0.0853 & 0.0879 & 0.0909 & 0.0946 & 0.0992 & 0.1061\end{array}$ $\begin{array}{lllllllll}0.1126 & 0.1181 & 0.1224 & 0.1254 & 0.1280 & 0.1295 & 0.1311 & 0.1319\end{array}$

SN $\quad \begin{array}{lllllllll}0.0000 & 0.0000 & 0.0000 & 0.0002 & 0.0011 & 0.0062 & 0.0258 & 0.0471\end{array}$ $\begin{array}{llllllllll}0.0617 & 0.0718 & 0.0776 & 0.0828 & 0.0866 & 0.0901 & 0.0933 & 0.0957\end{array}$ $\begin{array}{llllllllll}0.0983 & 0.1008 & 0.1032 & 0.1066 & 0.1101 & 0.1146 & 0.1217 & 0.1279\end{array}$ $\begin{array}{lllllllll}0.1333 & 0.1374 & 0.1404 & 0.1428 & 0.1443 & 0.1456 & 0.1466 & \text { - }\end{array}$

SP $\quad \begin{array}{lllllllll}0.0000 & 0.0000 & 0.0002 & 0.0002 & 0.0004 & 0.0004 & 0.0046 & 0.0412\end{array}$ $\begin{array}{lllllllll}0.0680 & 0.0907 & 0.1067 & 0.1154 & 0.1221 & 0.1273 & 0.1319 & 0.1356\end{array}$ $\begin{array}{lllllllll}0.1387 & 0.1421 & 0.1456 & 0.1489 & 0.1527 & 0.1568 & 0.1614 & 0.1662\end{array}$ $\begin{array}{llllllll}0.1710 & 0.1749 & 0.1776 & 0.1795 & 0.1810 & 0.1822 & 0.1835 & 0.1841\end{array}$ 
ID Cumulative Volumetric Porosity $\left(\mathrm{m}^{3} / \mathrm{m}^{3}\right)$ for Data in Table A5a

$\begin{array}{lllllllllll}\text { Z3 UW } & 0.0000 & 0.0004 & 0.0004 & 0.0020 & 0.0069 & 0.0140 & 0.0198 & 0.0261\end{array}$ $\begin{array}{llllllllll}0.0323 & 0.0363 & 0.0401 & 0.0435 & 0.0470 & 0.0501 & 0.0528 & 0.0557\end{array}$ $\begin{array}{lllllllllll}0.0582 & 0.0606 & 0.0631 & 0.0660 & 0.0698 & 0.0773 & 0.0867 & 0.0945\end{array}$ $\begin{array}{lllllllll}0.1010 & 0.1065 & 0.1110 & 0.1148 & 0.1179 & 0.1201 & 0.1221 & 0.1237\end{array}$

UC $\quad \begin{array}{lllllllll}0.0002 & 0.0006 & 0.0028 & 0.0073 & 0.0114 & 0.0270 & 0.0348 & 0.0397\end{array}$ $\begin{array}{llllllllll}0.0443 & 0.0479 & 0.0527 & 0.0574 & 0.0624 & 0.0663 & 0.0698 & 0.0726\end{array}$ $\begin{array}{lllllllll}0.0754 & 0.0780 & 0.0808 & 0.0840 & 0.0879 & 0.0935 & 0.1024 & 0.1110\end{array}$ $\begin{array}{lllllllll}0.1181 & 0.1242 & 0.1291 & 0.1324 & 0.1352 & 0.1371 & 0.1386 & 0.1402\end{array}$

UD

$\begin{array}{lllllllll}0.0295 & 0.0310 & 0.0318 & 0.0329 & 0.0346 & 0.0406 & 0.0492 & 0.0554\end{array}$ $\begin{array}{llllllllll}0.0607 & 0.0646 & 0.0688 & 0.0731 & 0.0772 & 0.0812 & 0.0844 & 0.0872\end{array}$ $\begin{array}{llllllllll}0.0900 & 0.0928 & 0.0955 & 0.0988 & 0.1017 & 0.1056 & 0.1126 & 0.1227\end{array}$ $\begin{array}{llllllllll}0.1300 & 0.1357 & 0.1402 & 0.1434 & 0.1460 & 0.1479 & 0.1492 & 0.1500\end{array}$

UE $\quad \begin{array}{llllllllll}0.0000 & 0.0004 & 0.0008 & 0.0021 & 0.0099 & 0.0164 & 0.0212 & 0.0250\end{array}$ $\begin{array}{llllllllll}0.0286 & 0.0311 & 0.0334 & 0.0357 & 0.0380 & 0.0401 & 0.0420 & 0.0437\end{array}$ $\begin{array}{llllllllll}0.0460 & 0.0481 & 0.0504 & 0.0531 & 0.0559 & 0.0598 & 0.0645 & 0.0695\end{array}$ $\begin{array}{llllllllll}0.0741 & 0.0783 & 0.0821 & 0.0848 & 0.0871 & 0.0888 & 0.0901 & 0.0911\end{array}$

UF $\quad \begin{array}{llllllllll}0.0000 & 0.0008 & 0.0023 & 0.0081 & 0.0156 & 0.0233 & 0.0352 & 0.0452\end{array}$ $\begin{array}{llllllllll}0.0535 & 0.0591 & 0.0637 & 0.0677 & 0.0716 & 0.0747 & 0.0777 & 0.0806\end{array}$ $\begin{array}{llllllllll}0.0837 & 0.0866 & 0.0904 & 0.0943 & 0.0969 & 0.1035 & 0.1110 & 0.1183\end{array}$ $\begin{array}{llllllllll}0.1243 & 0.1291 & 0.1333 & 0.1368 & 0.1393 & 0.1416 & 0.1432 & 0.1445\end{array}$

UG $\quad \begin{array}{lllllllll}0.0000 & 0.0002 & 0.0008 & 0.0028 & 0.0096 & 0.0230 & 0.0354 & 0.0450\end{array}$ $\begin{array}{lllllllll}0.0517 & 0.0589 & 0.0652 & 0.0717 & 0.0769 & 0.0815 & 0.0852 & 0.0886\end{array}$ $\begin{array}{lllllllll}0.0917 & 0.0949 & 0.0980 & 0.1008 & 0.1043 & 0.1095 & 0.1175 & 0.1247\end{array}$ $\begin{array}{llllllll}0.1310 & 0.1366 & 0.1412 & 0.1442 & 0.1468 & 0.1488 & 0.1503 & 0.1512\end{array}$

$\begin{array}{llllllllll}\text { UH } & & 0.0000 & 0.0002 & 0.0004 & 0.0010 & 0.0021 & 0.0039 & 0.0093 & 0.0093\end{array}$ $\begin{array}{lllllllllll}0.0255 & 0.0306 & 0.0356 & 0.0401 & 0.0442 & 0.0477 & 0.0506 & 0.0535\end{array}$ $\begin{array}{lllllllllll}0.0559 & 0.0586 & 0.0613 & 0.0644 & 0.0691 & 0.0759 & 0.0841 & 0.0913\end{array}$ $\begin{array}{llllllllll}0.0973 & 0.1026 & 0.1068 & 0.1100 & 0.1125 & 0.1146 & 0.1160 & 0.1170\end{array}$

$\begin{array}{llllllllll}\text { UJ } & 0.0000 & 0.0000 & 0.0002 & 0.0002 & 0.0017 & 0.0057 & 0.0190 & 0.0315\end{array}$ $\begin{array}{llllllllll}0.0433 & 0.0505 & 0.0560 & 0.0608 & 0.0643 & 0.0669 & 0.0693 & 0.0713\end{array}$ $\begin{array}{llllllllll}0.0739 & 0.0759 & 0.0781 & 0.0803 & 0.0833 & 0.0879 & 0.0960 & 0.1034\end{array}$ $\begin{array}{lllllllll}0.1098 & 0.1150 & 0.1196 & 0.1231 & 0.1257 & 0.1277 & 0.1292 & 0.1305\end{array}$

$\begin{array}{llllllllll}\text { UK } & \quad & 0.0000 & 0.0000 & 0.0000 & 0.0000 & 0.0000 & 0.0002 & 0.0020 & 0.0137\end{array}$ $\begin{array}{lllllllll}0.0331 & 0.0434 & 0.0506 & 0.0567 & 0.0614 & 0.0652 & 0.0682 & 0.0709\end{array}$ $\begin{array}{lllllllll}0.0731 & 0.0756 & 0.0781 & 0.0808 & 0.0835 & 0.0868 & 0.0916 & 0.0979\end{array}$ $\begin{array}{lllllllll}0.1035 & 0.1075 & 0.1116 & 0.1145 & 0.1165 & 0.1186 & 0.1199 & 0.1208\end{array}$

$\begin{array}{llllllllll}\text { UM } & 0.0000 & 0.0000 & 0.0002 & 0.0002 & 0.0002 & 0.0013 & 0.0081 & 0.0242\end{array}$ $\begin{array}{llllllllll}0.0390 & 0.0603 & 0.0751 & 0.0854 & 0.0932 & 0.0997 & 0.1034 & 0.1073\end{array}$ $\begin{array}{llllllllll}0.1095 & 0.1121 & 0.1143 & 0.1165 & 0.1187 & 0.1228 & 0.1265 & 0.1306\end{array}$ $\begin{array}{lllllllll}0.1324 & 0.1361 & 0.1391 & 0.1413 & 0.1435 & 0.1452 & 0.1468 & 0.1476\end{array}$ 
ID Cumulative Volumetric Porosity $\left(\mathrm{m}^{3} / \mathrm{m}^{3}\right)$ for Data in Table A5a

UN $\quad \begin{array}{llllllllll}0.0000 & 0.0002 & 0.0002 & 0.0004 & 0.0013 & 0.0040 & 0.0160 & 0.0294\end{array}$ $\begin{array}{llllllllll}0.0477 & 0.0635 & 0.0739 & 0.0804 & 0.0853 & 0.0889 & 0.0918 & 0.0944\end{array}$ $\begin{array}{llllllllll}0.0971 & 0.0998 & 0.1025 & 0.1054 & 0.1087 & 0.1132 & 0.1201 & 0.1276\end{array}$ $\begin{array}{lllllllll}0.1341 & 0.1390 & 0.1426 & 0.1457 & 0.1479 & 0.1495 & 0.1506 & 0.1515\end{array}$

UP $\quad \begin{array}{llllllllll}0.0000 & 0.0031 & 0.0084 & 0.0129 & 0.0177 & 0.0233 & 0.0284 & 0.0328\end{array}$ $\begin{array}{lllllllll}0.0368 & 0.0413 & 0.0453 & 0.0486 & 0.0515 & 0.0544 & 0.0572 & 0.0595\end{array}$ $\begin{array}{llllllllll}0.0621 & 0.0648 & 0.0670 & 0.0699 & 0.0730 & 0.0763 & 0.0819 & 0.0885\end{array}$ $\begin{array}{lllllll}0.0954 & 0.1007 & 0.1047 & 0.1076 & 0.1103 & 0.1116\end{array}$

$\begin{array}{llllllllll}\text { UR } & 0.0000 & 0.0000 & 0.0000 & 0.0002 & 0.0004 & 0.0015 & 0.0059 & 0.0232\end{array}$ $\begin{array}{llllllllll}0.0426 & 0.0595 & 0.0710 & 0.0796 & 0.0859 & 0.0905 & 0.0931 & 0.0966\end{array}$ $\begin{array}{llllllllll}0.0992 & 0.1023 & 0.1051 & 0.1080 & 0.1115 & 0.1152 & 0.1207 & 0.1279\end{array}$ $\begin{array}{lllllllll}0.1353 & 0.1408 & 0.1451 & 0.1480 & 0.1504 & 0.1523 & 0.1537 & 0.1545\end{array}$

US $\quad \begin{array}{llllllllll}0.0000 & 0.0000 & 0.0002 & 0.0002 & 0.0002 & 0.0128 & 0.0175 & 0.0222\end{array}$ $\begin{array}{llllllllll}0.0439 & 0.0646 & 0.0774 & 0.0874 & 0.0945 & 0.1000 & 0.1036 & 0.1070\end{array}$ $\begin{array}{llllllll}0.1100 & 0.1130 & 0.1162 & 0.1198 & 0.1237 & 0.1288 & 0.1350 & 0.1422\end{array}$ $\begin{array}{llllllll}0.1486 & 0.1533 & 0.1569 & 0.1599 & 0.1623 & 0.1638 & 0.1653 & 0.1661\end{array}$

UT $\quad \begin{array}{lllllllll}0.0000 & 0.0000 & 0.0000 & 0.0002 & 0.0006 & 0.0024 & 0.0088 & 0.0276\end{array}$ $\begin{array}{llllllllll}0.0558 & 0.0766 & 0.0888 & 0.0952 & 0.0995 & 0.1025 & 0.1046 & 0.1070\end{array}$ $\begin{array}{llllllllll}0.1093 & 0.1115 & 0.1136 & 0.1168 & 0.1207 & 0.1265 & 0.1331 & 0.1419\end{array}$ $\begin{array}{llllllllll}0.1498 & 0.1556 & 0.1598 & 0.1628 & 0.1652 & 0.1669 & 0.1682 & 0.1690\end{array}$

UU $\quad \begin{array}{llllllll}- & 0.0000 & 0.0000 & 0.0002 & 0.0009 & 0.0022 & 0.0059 & 0.0134\end{array}$ $\begin{array}{lllllllll}0.0296 & 0.0462 & 0.0569 & 0.0622 & 0.0672 & 0.0705 & 0.0736 & 0.0764\end{array}$ $\begin{array}{llllllllll}0.0788 & 0.0812 & 0.0839 & 0.0867 & 0.0900 & 0.0942 & 0.0996 & 0.1082\end{array}$ $\begin{array}{lllllllll}0.1182 & 0.1261 & 0.1314 & 0.1351 & 0.1380 & 0.1401 & 0.1417 & 0.1425\end{array}$ 
Table A6: Fracture geometric information obtained from oriented drill core. Depth of fracture is inclined along borehole.

\begin{tabular}{|c|c|c|c|c|c|c|c|c|c|}
\hline \multirow{2}{*}{\multicolumn{2}{|c|}{ ID }} & \multirow{2}{*}{$\begin{array}{l}\text { Depth } \\
\text { (m) }\end{array}$} & \multicolumn{2}{|c|}{ Orientation $\left({ }^{\circ}\right)$} & & \multirow[t]{2}{*}{ ID } & \multirow{2}{*}{$\begin{array}{l}\text { Depth } \\
\text { (m) }\end{array}$} & \multicolumn{2}{|c|}{ Orientation $\left({ }^{\circ}\right)$} \\
\hline & & & Strike & Dip & & & & Strike & Dip \\
\hline \multirow[t]{15}{*}{$\mathrm{XI}$} & $\mathrm{AA}$ & 1.77 & 345 . & 75 . & $\mathrm{x} 3$ & EA & - & - & - \\
\hline & $A B$ & - & - & - & & EB & - & - & - \\
\hline & $\mathrm{AC}$ & - & - & - & & EC & 4.14 & 356. & 74. \\
\hline & $\mathrm{AD}$ & 4.14 & 352. & 85. & & ED & $\begin{array}{l}4.67 \\
7.01\end{array}$ & 338. & 14. \\
\hline & & $\begin{array}{l}4.33 \\
4.36\end{array}$ & $\begin{array}{l}215 . \\
346 .\end{array}$ & $\begin{array}{l}12 . \\
73 .\end{array}$ & & EE & 8.82 & $\begin{array}{r}19 . \\
5 .\end{array}$ & $\begin{array}{r}6 . \\
79 .\end{array}$ \\
\hline & & 4.62 & 329 . & 76. & & & 9.02 & 337. & 76. \\
\hline & & 4.79 & 336. & 84. & & & $10: 13$ & 20 . & 73. \\
\hline & & 5.73 & 326. & 82 . & & $E F$ & 12.45 & 332 . & 83. \\
\hline & & 6.92 & 359. & 75 . & & & 13.32 & 343. & 76. \\
\hline & & 7.13 & 358. & 69. & & EG & 15.85 & 336. & 66. \\
\hline & $\mathrm{AE}$ & 8.92 & 31. & 48. & & & 18.63 & 11. & 67. \\
\hline & & 9.79 & 35. & 64. & & $\mathrm{EH}$ & 18.89 & 6. & 71. \\
\hline & $\mathrm{AF}$ & - & - & - & & EJ & $21: 03$ & 334. & 71. \\
\hline & $\mathrm{AG}$ & - & - & - & & EK & 25.60 & 10. & 67. \\
\hline & & & & & & & 25.72 & 336. & 66. \\
\hline \multirow[t]{20}{*}{$\mathrm{x} 2$} & $\mathrm{CA}$ & 1.77 & 359. & 82. & & EM & 28.68 & 8. & 74. \\
\hline & $\mathrm{CB}$ & $\begin{array}{l}2.32 \\
2.47\end{array}$ & $\begin{array}{l}300 . \\
359 .\end{array}$ & $\begin{array}{l}56 . \\
85 .\end{array}$ & & EN & $\begin{array}{l}29.66 \\
29.81\end{array}$ & $\begin{array}{r}329 . \\
11 .\end{array}$ & $\begin{array}{l}72 . \\
66 .\end{array}$ \\
\hline & $\mathrm{CC}$ & - & - & - & & & 30.55 & 312 . & 87. \\
\hline & $C D$ & 4.85 & 191. & 17. & & & 30.60 & 336. & 78. \\
\hline & & 5.18 & 354. & 84. & & & 31.08 & 328 . & 66. \\
\hline & $C E$ & 9.45 & 347. & 78. & & & 31.58 & 336. & 64. \\
\hline & $\mathrm{CF}$ & 13.38 & 331. & 75. & & EP & $32: 95$ & 332. & 85. \\
\hline & & 13.56 & 342. & 59. & & & 33.64 & 337. & 82. \\
\hline & CG & 15.59 & 20. & 17. & & & 34.46 & 339. & 87. \\
\hline & & 15.51 & 20. & 17. & & & 34.61 & 342. & 72. \\
\hline & $\mathrm{CH}$ & 18.68 & 32. & 47. & & & 35.13 & 324. & 81. \\
\hline & CJ & 19.95 & 327. & 89. & & ER & 35.23 & 323. & 80. \\
\hline & & 21.03 & 334. & 67. & & & 35.96 & 316. & 36. \\
\hline & & 21.67 & 16. & 30. & & ES & - & - & - \\
\hline & & 22.49 & 347. & 79. & & ET & 42.26 & 52. & 55. \\
\hline & CK & 24.78 & 339. & 76. & & & 42.64 & 309. & 86. \\
\hline & $\mathrm{CM}$ & 28.47 & 303. & 60. & & & & & \\
\hline & & 28.65 & 44. & 63. & & & & & \\
\hline & $\mathrm{CN}$ & 29.23 & 318. & 78. & & & & & \\
\hline & & 29.52 & 3 . & 72. & & & & & \\
\hline
\end{tabular}




\begin{tabular}{ccccc} 
ID $\ldots$ & Depth & \multicolumn{3}{c}{ Orientation } \\
& & (m) & Strike & Dip \\
Y1 GB & - & - & - \\
GC & 3.27 & 119. & 17. \\
GD & 3.73 & 169. & 89. \\
GA & 5.94 & 12. & 81. \\
GF & 10.20 & 316. & 34. \\
GG & 10.42 & 13. & 88. \\
& 11.77 & 291. & 1. \\
GH & 12.87 & 11. & 59. \\
& 14.79 & 21. & 72. \\
& ( & & & \\
Y2 JB & 2.26 & 336. & 69. \\
JC & 3.96 & 4. & 77. \\
JD & - & - & - \\
JE & 5.42 & 344. & 77. \\
& 5.85 & 345. & 69. \\
& 7.62 & 3. & 65. \\
JF & 8.29 & 264. & 76. \\
& 9.04 & 251. & 44. \\
JG & - & - & - \\
JH & 16.43 & 15. & 6. \\
JJ & 19.33 & 102. & 40. \\
& 19.77 & 237. & 26. \\
& 19.87 & 293. & 17. \\
JK & 22.40 & 25. & 56. \\
JM & - & - & - \\
JN & 28.62 & 214. & 87. \\
JP & - & - & - \\
& & &
\end{tabular}

ID Depth Orientation $\left({ }^{\circ}\right)$

(m) Strike Dip

Y3 MB

MC

MD

ME

4.48294 .22 .

$5.09 \quad .21$. 67.

5.25298 .4 .

6.51 311. 45 .

MF $\quad 9.57 \quad 26.74$.

MG $\quad 13.73 \quad 4 . \quad 77$.

MH $15.92 \quad 345 . \quad 84$.

MJ $17.21 \quad 160.89$.

17.37 348: 88 .

19.4326 .76 .

$19.77 \quad 17.73$.

MK $20.21 \quad 164.82$.

$20.31 \quad 4.67$.

M $\quad 23.33 \quad 24.65$.

$23.76350 . \quad 80$.

$23.80 \quad 341 . \quad 89$.

$24.39 \quad 340 . \quad 77$.

$24.40 \quad 336 . \quad 87$.

$24.49 \quad 343.66$.

MN $26.32 \quad 353 . \quad 81$.

MP $29.98 \quad 23 . \quad 74$.

MR - - $\quad-\quad$ -

MS

MT

MU $\quad 44.60 \quad 216.86$. 
Table A6 (Continued)

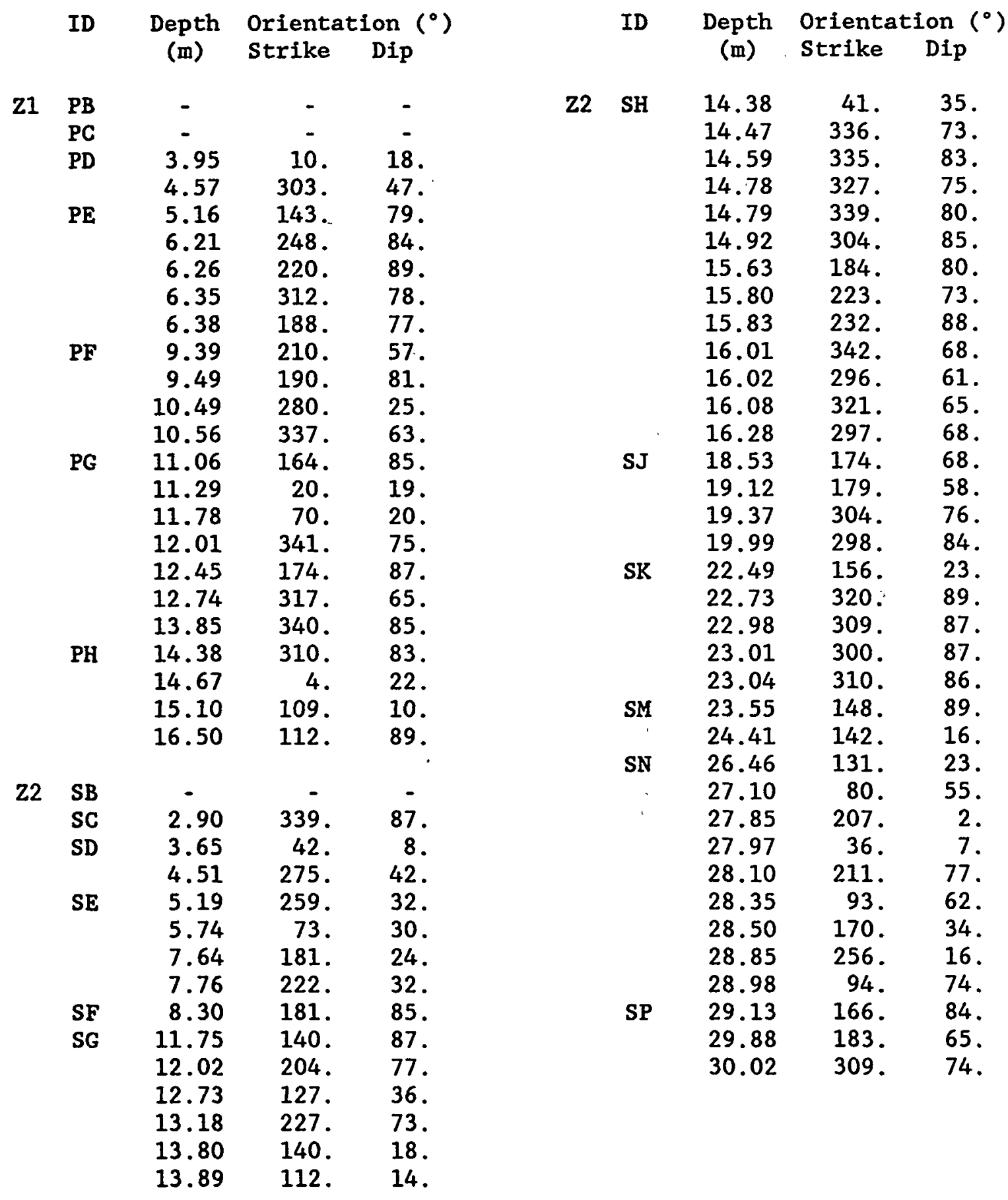


Table A7: Fracture density values obtained from borehole cores at the Apache Leap Tuff Site.

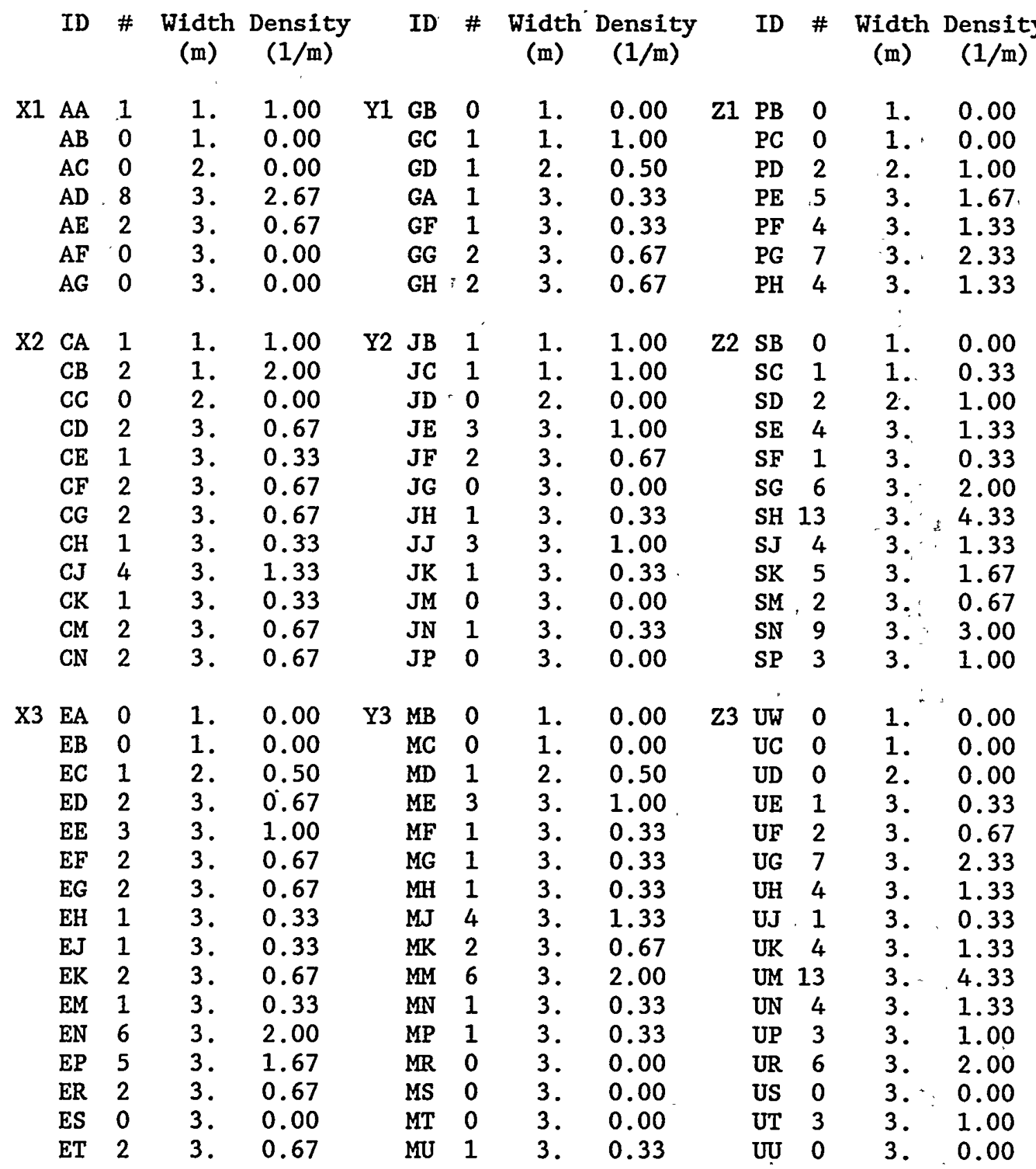




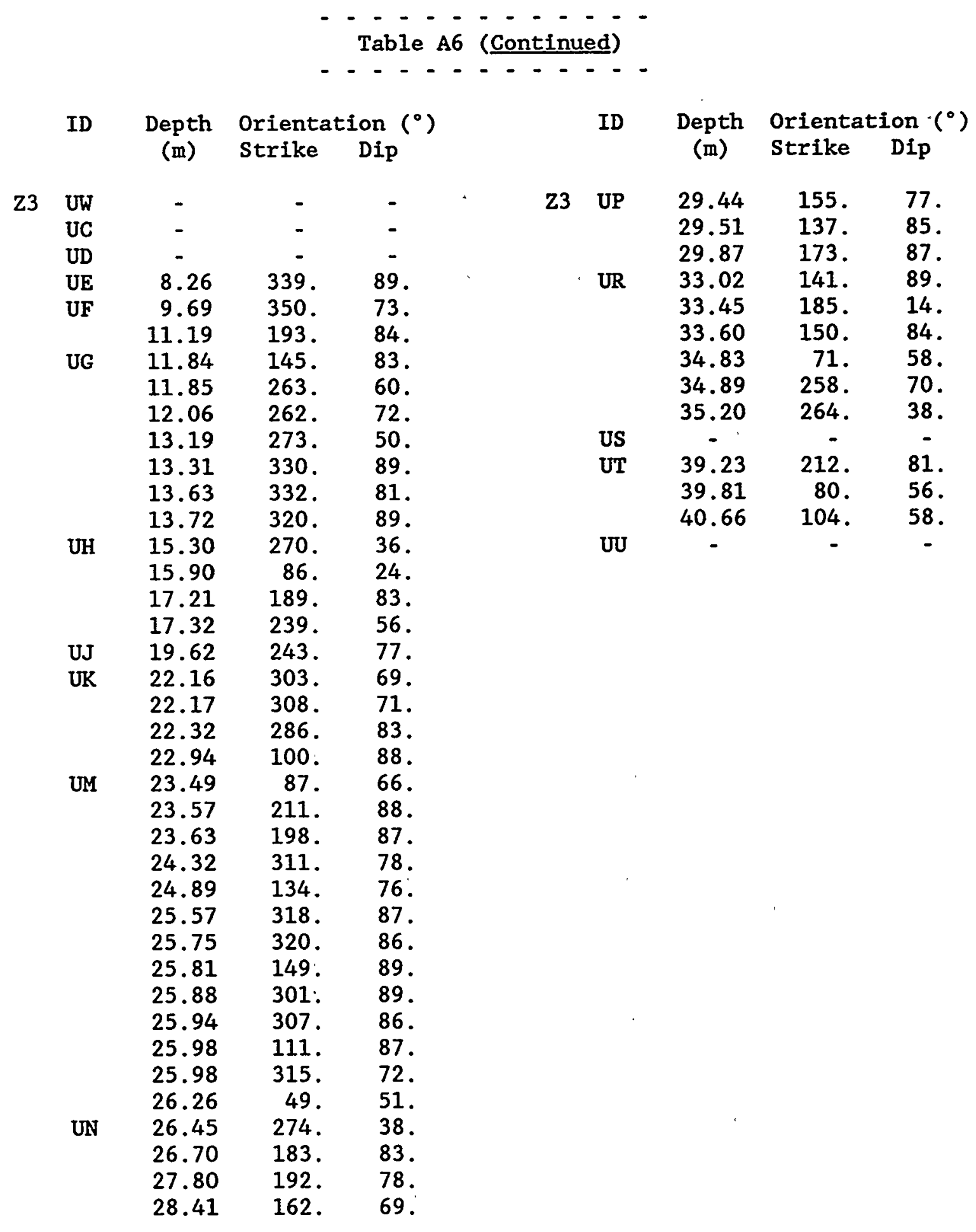


Table A8: Saturated hydraulic conductivity (Ksat) obtained from 105 large core segments at the Apache Leap Tuff Site.

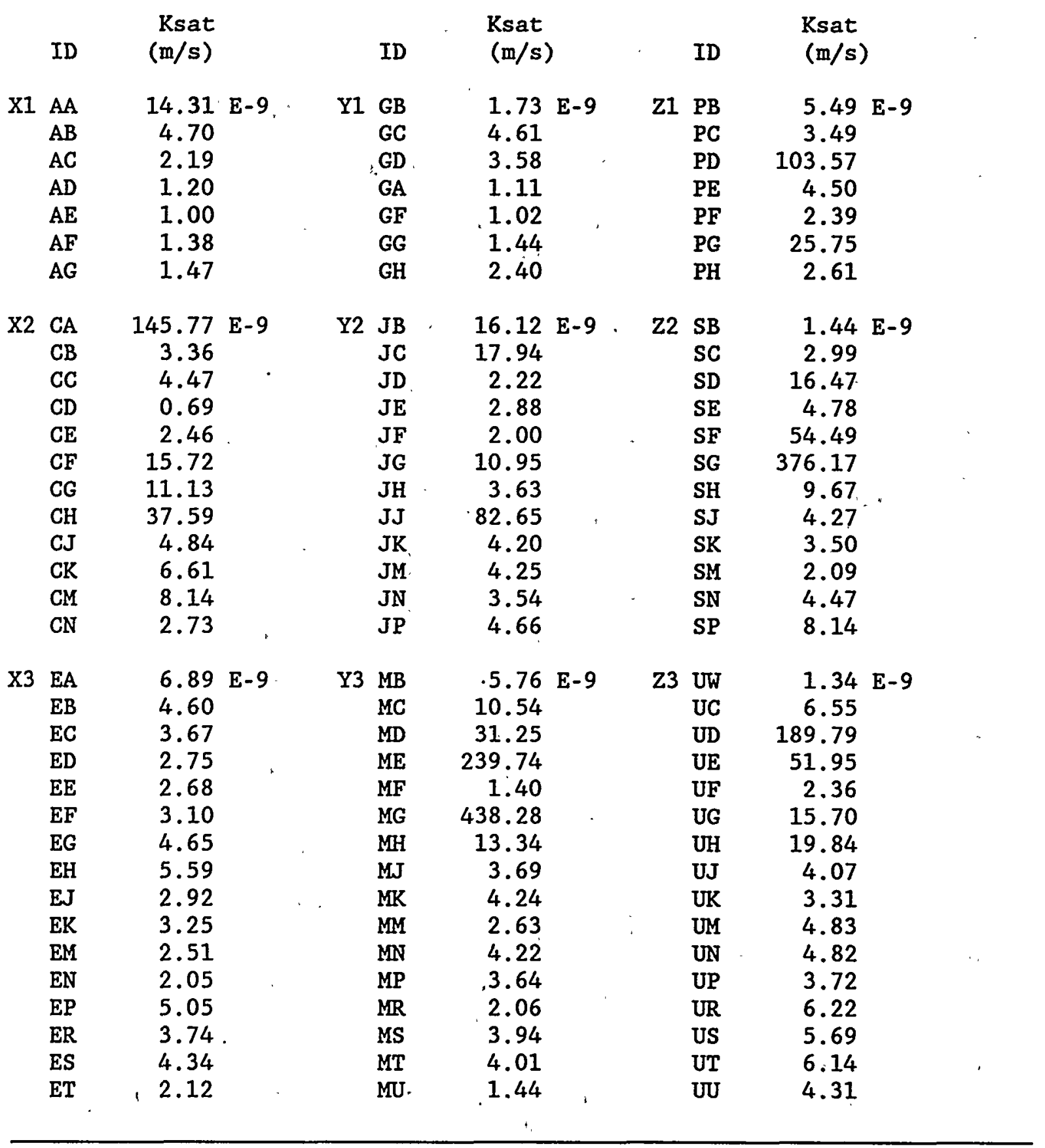


Table A9a: Laboratory moisture characteristic curves for 105 large core segments as a function of matric suction using pressure extractor. Data is relative saturation in percent.

PRESSURE EXTRACTOR MOISTURE CHARACTERISTIC CURVES

ID

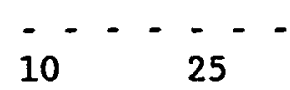

Suction

$$
50
$$$$
(\mathrm{kPa})
$$

300

$$
500
$$

$\mathrm{XI} A \mathrm{~A}$

$A B \quad 88.42$

AC $\quad 95.34$

AD $\quad 97.07$

$\mathrm{AE} \quad 95.96$

AF $\quad 94.59$

AG

97.27

$\mathrm{x} 2$

$\mathrm{CA} \quad 91.11$

CB

CC

$\mathrm{CD}$

CE

CF

CG

$\mathrm{CH}$

CJ

CK

CM

$\mathrm{CN}$

X3 EA

EB

EC

ED

EE

EF

EG

EH

EJ

EK

EM

EN

EP

ER

ES

ET
79.08

82.75

85.29

90.86

93.14

92.28

95.71

72.30

87.38

90.10

94.45

96.79

95.32

88.69

87.85

94.79

96.28

93.39

95.50

86.75

91.20

82.19

86.88

79.50

94.59

98.38

85.90

97.54

97.50

97.18

94.59

97.11

94.95

97.95

95.73
67.50

69.72

78.48

82.08

85.87

87.64

90.64

67.24

83.80

76.11

89.50

92.27

88.75

84.58

77.34

82.50

91.62

86.45

88.11

77.81

79.36

73.50

78.50

73.40

87.60

93.94

81.63

93.84

96.75

95.57

92.79

89.88

91.70

96.59

90.04
61.90
63.59
66.28
71.85
73.76
74.90
78.94

58.34

61.09

78.31

80.06

74.68

69.50

59.93

72.81

73.93

68.93

76.54

67.95

64.18

61.68

66.58

61.96

78.91

70.49

66.43

75.38

83.18

78.26

79.09

80.85

77.98

89.07

81.51
73.05
47.33

50.56

55.16

56.86

57.61

59.46

61.00

41.73

45.57

50.14

49.18

49.54

51.74

51.25

$49.75 \quad 46.00$

$59.99 \quad 56.35$

$53.58 \quad 51.54$

$65.25 \quad 48.81$

$60.41 \quad 54.54$

$57.95 \quad 50.75$

$50.99 \quad 45.85$

$48.98 \cdot 40.41$

$49.10 \quad 40.10$

$50.74 \quad 43.47$

$48.59 \quad 39.91$

$57.16 \quad 51.93$

$57.50 \quad 53.55$

$57.57 \quad 54.26$

$61.79 \quad 58.74$

$61.92 \quad 51.71$

$63.52 \quad 52.70$

$59.58 \quad 53.52$

$58.08 \quad 52.28$

$62.25 \quad 54.86$

$70.45 \quad 57.72$

$64.17 \quad 56.92$

$55.30 \quad 48.81$

$50.51 \quad 40.03$

$55.60 \quad 48.74$

$58.35 \quad 48.79$

$58.75 \quad 48.08$
$42.20 \quad 36.29$ 
Table A9a (Continued)

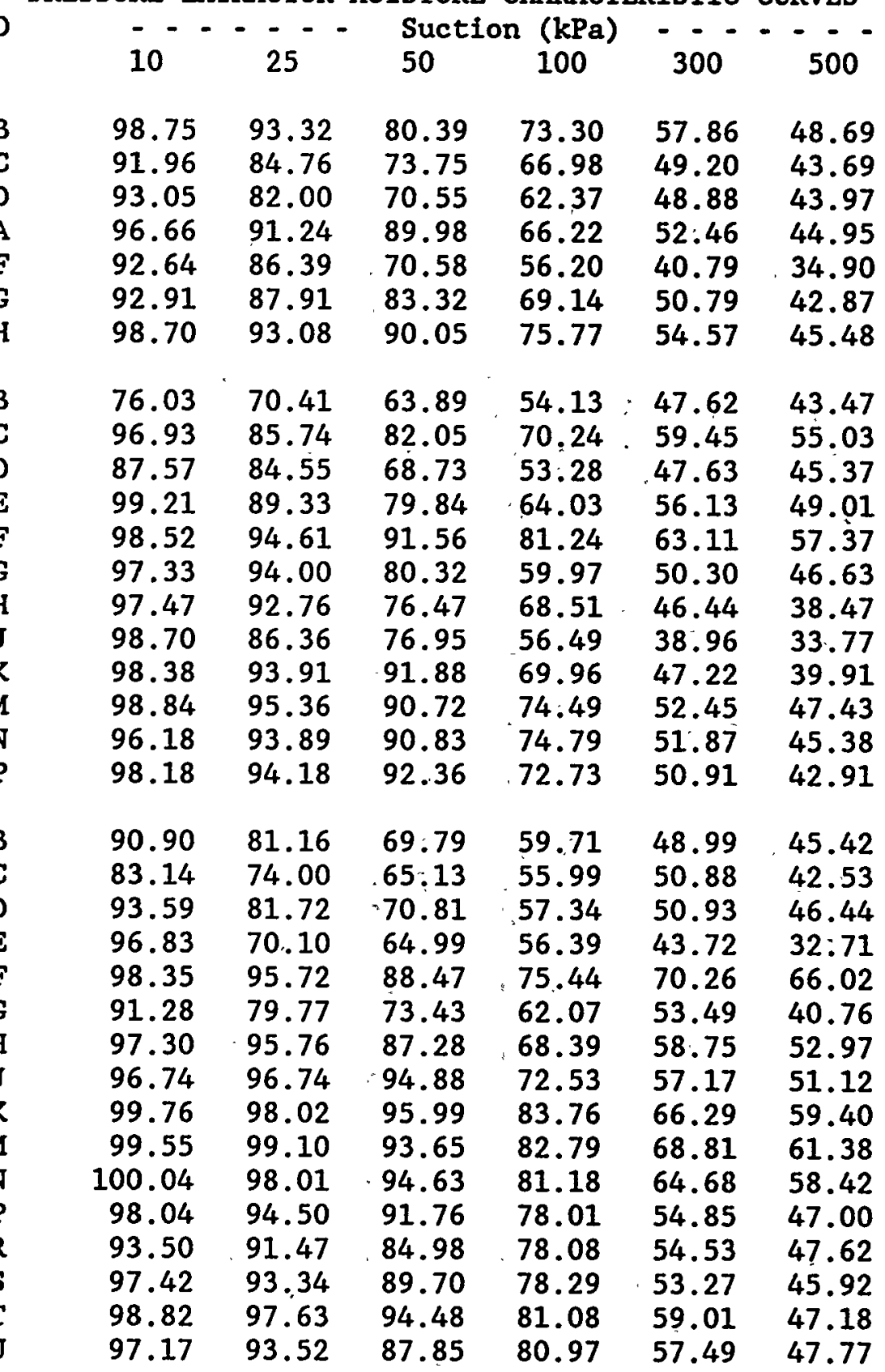


Table A9a (Continued)

PRESSURE EXTRACTOR MOISTURE CHARACTERISTIC CURVES ID

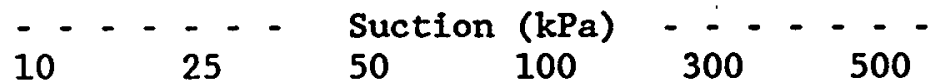

\begin{tabular}{|c|c|c|c|c|c|c|}
\hline $\begin{array}{ll}21 & \text { PB } \\
\text { PC } \\
\text { PD } \\
\text { PE } \\
\text { PF } \\
\text { PG } \\
\text { PH }\end{array}$ & $\begin{array}{l}94.28 \\
93.96 \\
93.60 \\
95.54 \\
90.77 \\
90.80 \\
98.09\end{array}$ & $\begin{array}{l}83.92 \\
87.80 \\
85.28 \\
87.20 \\
87.20 \\
83.49 \\
93.14\end{array}$ & $\begin{array}{l}75.35 \\
78.75 \\
76.31 \\
81.16 \\
81.80 \\
73.45 \\
84.93\end{array}$ & $\begin{array}{l}64.63 \\
68.85 \\
63.83 \\
69.81 \\
68.87 \\
63.25 \\
68.11\end{array}$ & $\begin{array}{l}56.41 \\
58.14 \\
57.11 \\
64.96 \\
62.80 \\
57.31 \\
61.25\end{array}$ & $\begin{array}{l}52.13 \\
43.34 \\
52.62 \\
60.90 \\
50.67 \\
46.10 \\
55.39\end{array}$ \\
\hline $\begin{array}{l}\text { SB } \\
\text { SC } \\
\text { SD } \\
\text { SE } \\
\text { SF } \\
\text { SG } \\
\text { SH } \\
\text { SJ } \\
\text { SK } \\
\text { SM } \\
\text { SN } \\
\text { SP }\end{array}$ & $\begin{array}{r}83.60 \\
96.67 \\
96.87 \\
98.41 \\
96.77 \\
97.62 \\
98.08 \\
92.82 \\
100.33 \\
99.06 \\
98.80 \\
98.98\end{array}$ & $\begin{array}{l}78.91 \\
88.75 \\
88.41 \\
90.44 \\
92.89 \\
86.80 \\
95.01 \\
90.97 \\
97.95 \\
96.26 \\
98.05 \\
98.71\end{array}$ & $\begin{array}{l}70.71 \\
82.92 \\
82.32 \\
80.88 \\
79.65 \\
71.22 \\
88.11 \\
85.27 \\
97.57 \\
94.86 \\
96.27 \\
97.08\end{array}$ & $\begin{array}{l}61.73 \\
67.92 \\
72.48 \\
64.94 \\
62.86 \\
50.37 \\
69.70 \\
65.34 \\
71.65 \\
81.29 \\
76.10 \\
84.51\end{array}$ & $\begin{array}{l}53.53 \\
58.75 \\
56.46 \\
56.97 \\
54.13 \\
42.98 \\
57.42 \\
55.72 \\
64.41 \\
66.32 \\
65.63 \\
64.43\end{array}$ & $\begin{array}{l}49.24 \\
52.50 \\
55.41 \\
49.80 \\
52.20 \\
40.34 \\
51.29 \\
40.95 \\
55.90 \\
59.31 \\
50.82 \\
47.95\end{array}$ \\
\hline $\begin{array}{l}\text { UW } \\
\text { UC } \\
\text { UD } \\
\text { UE } \\
\text { UF } \\
\text { UG } \\
\text { UH } \\
\text { UJ } \\
\text { UK } \\
\text { UM } \\
\text { UN } \\
\text { UP } \\
\text { UR } \\
\text { US } \\
\text { UT } \\
\text { UU }\end{array}$ & $\begin{array}{r}97.00 \\
93.17 \\
86.59 \\
82.59 \\
94.05 \\
96.14 \\
96.50 \\
99.55 \\
96.86 \\
99.57 \\
98.24 \\
100.18 \\
99.23 \\
99.96 \\
99.24 \\
92.97\end{array}$ & $\begin{array}{l}90.16 \\
85.14 \\
71.41 \\
78.14 \\
87.31 \\
91.92 \\
92.30 \\
98.65 \\
96.41 \\
97.92 \\
97.80 \\
98.99 \\
96.55 \\
97.52 \\
98.60 \\
92.72\end{array}$ & $\begin{array}{l}83.31 \\
71.08 \\
59.05 \\
68.83 \\
82.55 \\
77.53 \\
78.65 \\
95.52 \\
94.17 \\
94.93 \\
95.59 \\
96.89 \\
94.63 \\
96.50 \\
97.16 \\
90.91\end{array}$ & $\begin{array}{r}70.47 \\
65.06 \\
48.82 \\
56.68 \\
68.68 \\
65.59 \\
60.80 \\
71.75 \\
75.31 \\
82.96 \\
78.85 \\
81.73 \\
770.08 \\
80.16 \\
78.73 \\
75.28\end{array}$ & $\begin{array}{l}57.64 \\
47.39 \\
38.23 \\
46.56 \\
56.38 \\
43.47 \\
50.65 \\
59.19 \\
58.71 \\
44.95 \\
60.78 \\
75.06 \\
56.66 \\
68.47 \\
67.15 \\
65.85\end{array}$ & $\begin{array}{l}52.20 \\
40.16 \\
33.64 \\
40.49 \\
49.25 \\
33.99 \\
45.05 \\
53.81 \\
49.73 \\
58.95 \\
53.28 \\
69.71 \\
50.90 \\
65.34 \\
53.04 \\
51.22\end{array}$ \\
\hline
\end{tabular}


Table A9b: Laboratory moisture characteristic curves for 105 small segments. Data is matric suction in. $\mathrm{MPa}$ and dimensionless relative saturation.

ID

PSYCHROMETRIC MOISTURE CHARACTERISTIC CURVES Suction, MPa (above)

Relative Saturation, dimensionless (below)

$\begin{array}{llllllllllllll}\mathrm{X} 1 \mathrm{AA} & 0.6 & 0.8 & 1.8 & 2.6 & 4.0 & 5.6 & 12.4 & 17.6 & 29.3 & 53.8 & 60.9\end{array}$

$\begin{array}{llllllllllll}0.70 & 0.54 & 0.47 & 0.38 & 0.34 & 0.30 & 0.25 & 0.23 & 0.20 & 0.15 & 0.10\end{array}$

$\begin{array}{llllllllllll}\mathrm{AB} & 0.5 & 0.8 & 1.2 & 2.6 & 3.3 & 7.4 & 12.1 & 25.3 & 33.7 & 53.1 & 5.21\end{array}$

$\begin{array}{llllllllllll}0.70 & 0.54 & 0.48 & 0.40 & 0.37 & 0.29 & 0.24 & 0.21 & 0.20 & 0.17 & 0.10\end{array}$

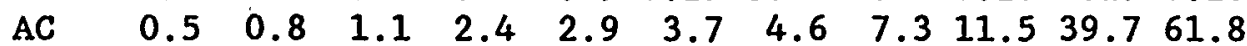

$\begin{array}{llllllllllll}0.70 & 0.60 & 0.56 & 0.47 & 0.44 & 0.40 & 0.37 & 0.34 & 0.30 & 0.20 & 0.12\end{array}$

$\begin{array}{llllllllllll}\mathrm{AD} & 0.5 & 0.6 & 0.7 & 0.9 & 1.7 & 2.6 & 3.1 & 4.0 & 7.6 & 29.4 & 68.0\end{array}$

$\begin{array}{llllllllllll}0.70 & 0.62 & 0.60 & 0.50 & 0.47 & 0.44 & 0.40 & 0.38 & 0.30 & 0.19 & 0.10\end{array}$

$\begin{array}{llllllllllll}\mathrm{AE} & 0.5 & 0.6 & 0.7 & 0.9 & 1.7 & 2.9 & 4.0 & 5.9 & 10.2 & 37.9 & 62.6\end{array}$

$\begin{array}{lllllllllll}0.70 & 0.61 & 0.56 & 0.45 & 0.41 & 0.36 & 0.32 & 0.30 & 0.25 & 0.16 & 0.09\end{array}$

$\begin{array}{lllllllllll}\mathrm{AF} & 0.5 & 0.6 & 0.6 & 0.7 & 0.8 & 1.1 & 1.5 & 3.0 & 5.8 & 48.3\end{array}$

$\begin{array}{llllllllll}0.70 & 0.58 & 0.53 & 0.43 & 0.40 & 0.34 & 0.30 & 0.25 & 0.20 & 0.10\end{array}$

AG $\quad \begin{array}{lllllllllll}0.6 & 0.6 & 0.6 & 0.8 & 1.2 & 2.1 & 3.2 & 4.8 & 7.6 & 50.2 & 6.79\end{array}$

$\begin{array}{llllllllllll}0.70 & 0.63 & 0.59 & 0.46 & 0.43 & 0.37 & 0.33, & 0.30 & 0.25 & 0.13 & 0.09\end{array}$

$\begin{array}{llllllllllllll}\mathrm{X} 2 & \mathrm{CA} & 0.4 & 0.5 & 0.6 & 0.6 & 1.5 & 1.9 & 2.1 & 4.5 & 7.4 & 10.1 & 26.7 & 42.8\end{array}$

$\begin{array}{llllllllllll}0.70 & 0.65 & 0.58 & 0.51 & 0.38 & 0.36 & 0.30 & 0.24 & 0.20 & 0.18 & 0.13 & 0.09\end{array}$

$\begin{array}{llllllllllllll}\text { GB } & 0.5 & 0.5 & 0.7 & 1.0 & 1.9 & 2.8 & 3.5 & 5.0 & 7.3 & 11.0 & 18.4 & 28.1 & 33.8\end{array}$

$\begin{array}{lllllllllllll}0.70 & 0.62 & 0.57 & 0.53 & 0.45 & 0.40 & 0.33 & 0.30 & 0.25 & 0.23 & 0.20 & 0.17 & 0.16\end{array}$

69.3

0.10

CC $\quad \begin{array}{llllllllllllllll}0.6 & 0.9 & 1.4 & 2.2 & 3.8 & 4.6 & 12.5 & 15.7 & 16.8 & 21.2 & 33.1 & 65.5 & 104 .\end{array}$ $\begin{array}{lllllllllllll}0.70 & 0.66 & 0.60 & 0.57 & 0.51 & 0.45 & 0.37 & 0.34 & 0.34 & 0.32 & 0.30 & 0.20 & 0.16\end{array}$

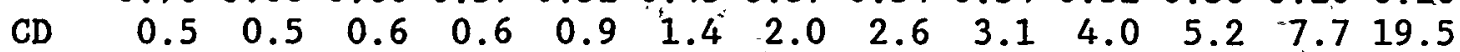

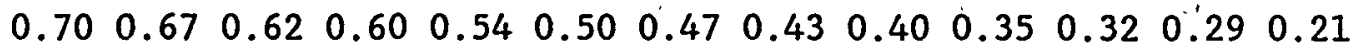
$26.7 \quad 36.160 .068 .7$

$\begin{array}{llll}0.19 & 0.17 & 0.14 & 0.10\end{array}$

CE $\quad \begin{array}{lllllllllllllll}0.6 & 0.6 & 0.6 & 0.6 & 0.8 & 1.3 & 2.4 & 3.3 & 4.6 & 5.8 & 10.1 & 17.8 & 33.1\end{array}$

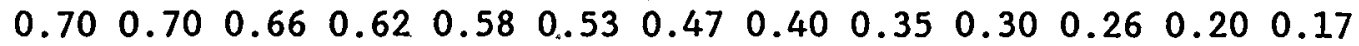
48.272 .1

0.150 .12

CF $\quad \begin{array}{lllllllllllll}0.5 & 0.5 & 0.5 & 0.6 & 0.6 & 0.9 & 1.0 & 1.9 & 3.3 & 4.4 & 6.8 & 15.7 & 53.8\end{array}$ $\begin{array}{lllllllllllll}0.70 & 0.67 & 0.63 & 0.59 & 0.54 & 0.50 & 0.45 & 0.40 & 0.36 & 0.30 & 0.26 & 0.21 & 0.11\end{array}$

CG $\quad \begin{array}{lllllllllllll}0.5 & 0.5 & 0.6 & 0.6 & 0.6 & 0.7 & 1.0 & 1.7 & 2.7 & 3.4 & 5.0 & 5.6 & 9.0\end{array}$ $\begin{array}{llllllllllllllll}0.70 & 0.64 & 0.60 & 0.56 & 0.53 & 0.50 & 0.47 & 0.45 & 0.40 & 0.37 & 0.34 & 0.31 & 0.27\end{array}$ $16.4 \quad 49.067 .6$ $\begin{array}{llll}0.24 & 0.15 & 0.11\end{array}$

$\begin{array}{llllllllllllll}\mathrm{CH} & 0.4 & 0.6 & 0.5 & 0.5 & 0.5 & 0.6 & 1.0 & 1.3 & 2.5 & 4.0 & 5.8 & 10.3 & 20.2\end{array}$ $\begin{array}{lllllllllllll}0.68 & 0.64 & 0.60 & 0.55 & 0.51 & 0.47 & 0.45 & 0.37 & 0.34 & 0.30 & 0.26 & 0.22 & 0.18\end{array}$ 51.4 0.10 
PSYCHROMETRIC MOISTURE CHARACTERISTIC CURVES

ID

Suction, $\mathrm{MPa}$ (above)

Relative Saturation, dimensionless (below)

CJ $\quad \begin{array}{llllllllllllll}0.5 & 0.5 & 0.6 & 0.6 & 0.5 & 0.7 & 0.8 & 1.0 & 1.2 & 2.0 & 3.7 & 5.2 & 7.7\end{array}$

$\begin{array}{lllllllllllll}0.70 & 0.64 & 0.60 & 0.57 & 0.50 & 0.45 & 0.40 & 0.35 & 0.30 & 0.27 & 0.21 & 0.19 & 0.17\end{array}$

52.3

0.06

$\begin{array}{llllllllllllll}\mathrm{CK} & 0.5 & 0.5 & 0.6 & 0.7 & 0.9 & 1.4 & 2.8 & 3.6 & 4.6 & 6.6 & 11.3 & 13.9 & 51.0\end{array}$

$\begin{array}{lllllllllllll}0.70 & 0.60 & 0.54 & 0.51 & 0.43 & 0.37 & 0.30 & 0.25 & 0.22 & 0.20 & 0.16 & 0.15 & 0.07\end{array}$

$\begin{array}{llllllllllllll}\mathrm{CM} & 0.4 & 0.4 & 0.5 & 0.6 & 0.8 & 1.2 & 1.8 & 2.8 & 3.6 & 4.5 & 7.9 & 11.7 & 16.1\end{array}$

$\begin{array}{lllllllllllll}0.70 & 0.63 & 0.58 & 0.55 & 0.47 & 0.42 & 0.38 & 0.33 & 0.30 & 0.26 & 0.20 & 0.18 & 0.16\end{array}$ 49.1

0.07

CN $\quad \begin{array}{llllllllllllll} & 0.5 & 0.5 & 0.6 & 0.7 & 1.4 & 2.2 & 3.0 & 4.3 & 5.7 & 12.2 & 18.2 & 22.6 & 21.0\end{array}$

$\begin{array}{llllllllllllll}0.70 & 0.63 & 0.57 & 0.53 & 0.45 & 0.40 & 0.34 & 0.28 & 0.24 & 0.17 & 0.14 & 0.14 & 0.14\end{array}$

43.9

0.08

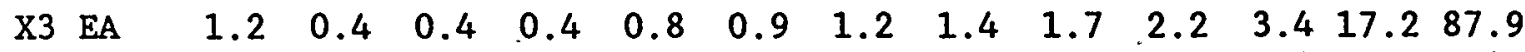

$\begin{array}{lllllllllllll}0.70 & 0.64 & 0.61 & 0.58 & 0.55 & 0.47 & 0.44 & 0.41 & 0.38 & 0.34 & 0.30 & 0.19 & 0.10\end{array}$

EB $\quad \begin{array}{lllllllllllll}0.4 & 0.6 & 0.8 & 0.9 & 1.3 & 1.7 & 2.2 & 2.6 & 3.3 & 4.2 & 6.5 & 11.2 & 34.4\end{array}$

$\begin{array}{lllllllllllll}0.70 & 0.65 & 0.61 & 0.58 & 0.54 & 0.50 & 0.45 & 0.42 & 0.40 & 0.35 & 0.32 & 0.27 & 0.16\end{array}$ 89.2

0.09

EC $\quad \begin{array}{lllllllllllll}0.5 & 0.5 & 0.7 & 1.0 & 1.5 & 1.9 & 3.4 & 4.2 & 5.7 & 8.0 & 10.7 & 15.9 & 34.6\end{array}$

$\begin{array}{lllllllllllll}0.70 & 0.63 & 0.56 & 0.52 & 0.49 & 0.45 & 0.36 & 0.33 & 0.31 & 0.28 & 0.26 & 0.24 & 0.18\end{array}$ 88.5

0.12

ED $\quad \begin{array}{llllllllllllll}0.5 & 0.6 & 0.6 & 0.7 & 1.1 & 2.3 & 3.0 & 3.8 & 11.9 & 16.9 & 25.1 & 46.8 & 80.4\end{array}$ $\begin{array}{lllllllllllll}0.67 & 0.63 & 0.59 & 0.55 & 0.50 & 0.42 & 0.38 & 0.35 & 0.25 & 0.23 & 0.21 & 0.16 & 0.11\end{array}$

$\begin{array}{lllllllll}\mathrm{EE} & 0.6 & 0.8 & 1.1 & 3.1 & 5.1 & 11.7 & 47.0\end{array}$

$\begin{array}{llllllll}0.70 & 0.57 & 0.50 & 0.40 & 0.29 & 0.20 & 0.09\end{array}$

EF $\quad \begin{array}{llllllll}0.6 & 1.1 & 2.1 & 4.3 & 3.8 & 19.0 & 72.9\end{array}$

$\begin{array}{llllllll}0.70 & 0.59 & 0.50 & 0.40 & 0.31 & 0.22 & 0.12\end{array}$

EG $\quad \begin{array}{llllllll}0.5 & 0.6 & 0.7 & 2.3 & 4.3 & 10.4 & 76.2\end{array}$

$\begin{array}{lllllll}0.72 & 0.57 & 0.50 & 0.40 & 0.30 & 0.20 & 0.09\end{array}$

$\begin{array}{llllllll}\text { EH } & 0.5 & 0.6 & 0.7 & 2.0 & 4.6 & 11.6 & 46.2\end{array}$

$\begin{array}{llllllll}0.71 & 0.60 & 0.50 & 0.39 & 0.30 & 0.21 & 0.12\end{array}$

EJ $\quad \begin{array}{llllllll}0.5 & 0.7 & 0.9 & 2.2 & 3.3 & 10.2 & 44.4\end{array}$

$\begin{array}{llllllll}0.65 & 0.58 & 0.47 & 0.39 & 0.29 & 0.20 & 0.08\end{array}$

$\begin{array}{lllllllll}\text { EK } & 0.6 & 0.6 & 0.8 & 2.2 & 4.8 & 11.3 & 40.4\end{array}$

$\begin{array}{llllllll}0.70 & 0.59 & 0.50 & 0.40 & 0.30 & 0.21 & 0.12\end{array}$

$\begin{array}{lllllllll}\text { EM } & 0.6 & 0.6 & 0.8 & 2.5 & 4.5 & 10.5 & 38.0\end{array}$

$\begin{array}{lllllll}0.70 & 0.60 & 0.50 & 0.40 & 0.32 & 0.21 & 0.11\end{array}$

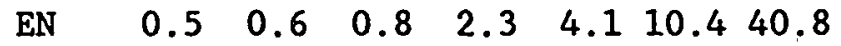

$\begin{array}{lllllllll}0.71 & 0.60 & 0.49 & 0.40 & 0.32 & 0.20 & 0.10\end{array}$

EP $\quad \begin{array}{llllllll}0.5 & 0.6 & 0.7 & 0.9 & 1.5 & 5.7 & 44.1\end{array}$

$\begin{array}{llllllll}0.70 & 0.60 & 0.50 & 0.40 & 0.30 & 0.20 & 0.08\end{array}$

$\begin{array}{llllllll}\text { ER } & 0.5 & 0.6 & 0.7 & 1.7 & 3.7 & 9.2 & 79.2\end{array}$

$\begin{array}{lllllll}0.70 & 0.60 & 0.50 & 0.40 & 0.30 & 0.21 & 0.09\end{array}$ 
Table A9b (Continued)

ID

PSYCHROMETRIC MOISTURE CHARACTERISTIC CURVES

Suction, MPa (above)

Relative Saturation, dimensionless (below)

ES

$\begin{array}{lllllll}0.5 & 0.7 & 1.2 & 3.1 & 4.9 & 14.0 & 78.9 .\end{array}$

$\begin{array}{llllllll}0.70 & 0.60 & 0.50 & 0.40 & 0.30 & 0.20 & 0.10\end{array}$

ET $\quad \begin{array}{llllllll}0.6 & 0.7 & 1.8 & 3.7 & 5.8 & 23.1 & 82.3\end{array}$

$\begin{array}{llllllll}0.70 & 0.60 & 0.50 & 0.40 & 0.30 & 0.20 & 0.11\end{array}$

Y1 GB. $\quad \begin{array}{llllllll}0.5 & 0.9 & 1.9 & 3.8 & 7.5 & 36.6 & 126 .\end{array}$

$\begin{array}{llllllll}0.70 & 0.60 & 0.50 & 0.40 & 0.30 & 0.20 & 0.12\end{array}$

GC

$\begin{array}{llllllll}0.6 & 1.1 & 2.5 & 4.5 & 7.9 & 34.8 & 124 .\end{array}$

$\begin{array}{llllllll}0.70 & 0.60 & 0.50 & 0.40 & 0.31 & 0.20 & 0.12\end{array}$

GD

$\begin{array}{lllllll}0.5 & 0.9 & 2.5 & 3.9 & 6.7 & 23.4 & 98.7\end{array}$

$\begin{array}{llllllll}0.70 & 0.60 & 0.50 & 0.40 & 0.30 & 0.20 & 0.12\end{array}$

GA $\quad \begin{array}{llllllll}0.6 & 0.6 & 1.2 & 3.0 & 5.4 & 15.8 & 82.9\end{array}$

$\begin{array}{llllllll}0.70 & 0.60 & 0.50 & 0.40 & 0.30 & 0.20 & 0.10\end{array}$

GF $\quad \begin{array}{llllllll}0.4 & 0.5 & 0.6 & 0.8 & 1.3 & 4.7 & 55.1\end{array}$

$\begin{array}{llllllll}0.70 & 0.60 & 0.50 & 0.40 & 0.30 & 0.20 & 0.05\end{array}$

GG $\begin{array}{llllllllll}0.6 & 0.5 & 0.6 & 0.7 & 1.3 & 3.5 & 12.1 & 27.3\end{array}$

$\begin{array}{llllllll}0.68 & 0.59 & 0.50 & 0.43 & 0.30 & 0.19 & 0.10 & 0.09\end{array}$

GH $\quad \begin{array}{llllllll}0.5 & 0.7 & 0.7 & 3.0 & 4.5 & 9.9 & 26.2 & 45.1\end{array}$

$\begin{array}{llllllll}0.69 & 0.60 & 0.50 & 0.36 & 0.30 & 0.20 & 0.11 & 0.10\end{array}$

Y2 JB

$\begin{array}{lllllllll}\text { JB } & 0.5 & 0.6 & 1.0 & 1.5 & 4.4 & 11.8 & 60.0\end{array}$

$\begin{array}{llllllll}0.70 & 0.60 & 0.49 & 0.44 & 0.30 & 0.20 & 0.12\end{array}$

JC $\quad \begin{array}{lllllllll}0.6 & 1.3 & 1.8 & 2.3 & 7.3 & 23.2 & 67.2 & 97.6\end{array}$

$\begin{array}{llllllllll}0.69 & 0.58 & 0.49 & 0.43 & 0.31 & 0.20 & 0.16 & 0.14\end{array}$

JD $\quad \begin{array}{lllllllll}0.5 & 0.6 & 0.5 & 0.5 & 1.7 & 4.5 & 18.4 & 42.2\end{array}$

$\begin{array}{lllllllll}0.70 & 0.60 & 0.50 & 0.44 & 0.28 & 0.19 & 0.10 & 0.09\end{array}$

JE $\quad \begin{array}{llllllllll}0.6 & 0.8 & 1.8 & 2.5 & 10.1 & 26.2 & 52.4 & 67.9\end{array}$

$\begin{array}{llllllll}0.69 & 0.60 & 0.50 & 0.45 & 0.31 & 0.20 & 0.15 & 0.13\end{array}$

JF $\quad \begin{array}{lllllllll}0.5 & 0.5 & 0.6 & 0.6 & 1.6 & 5.6 & 24.1 & 37.0\end{array}$

$\begin{array}{lllllllll}0.69 & 0.60 & 0.47 & 0.39 & 0.26 & 0.18 & 0.10 & 0.10\end{array}$

JG $\quad \begin{array}{llllllllll}0.6 & 0.6 & 0.9 & 1.8 & 4.5 & 10.5 & 32.2 & 35.3\end{array}$

$\begin{array}{llllllll}0.71 & 0.59 & 0.48 & 0.41 & 0.30 & 0.21 & 0.13 & 0.13\end{array}$

$\begin{array}{llllllll}\mathrm{JH} & 0.5 & 0.5 & 0.5 & 0.8 & 1.1 & 3.2 & 16.2\end{array}$

$\begin{array}{llllllll}0.70 & 0.60 & 0.49 & 0.40 & 0.30 & 0.20 & 0.09\end{array}$

JJ $\quad \begin{array}{lllllllll} & 0.5 & 0.6 & 0.6 & 0.6 & 1.4 & 2.2 & 7.3 & 34.7\end{array}$

$\begin{array}{lllllllll}0.70 & 0.67 & 0.60 & 0.50 & 0.39 & 0.36 & 0.20 & 0.12\end{array}$

$\begin{array}{lllllllll}\mathrm{JK} & 0.5 & 0.5 & 0.6 & 0.6 & 0.7 & 1.0 & 3.4 & 17.3\end{array}$

$\begin{array}{lllllllll}0.70 & 0.66 & 0.60 & 0.50 & 0.38 & 0.35 & 0.19 & 0.10\end{array}$

$\begin{array}{llllllllll}\text { JM } & 0.5 & 0.5 & 0.4 & 0.6 & 0.8 & 1.2 & 5.0 & 25.6\end{array}$

$\begin{array}{lllllllll}0.70 & 0.68 & 0.60 & 0.50 & 0.39 & 0.37 & 0.21 & 0.11\end{array}$

JN $\quad \begin{array}{llllllll}0.5 & 0.5 & 0.5 & 0.8 & 2.2 & 3.0 & 11.4 & 57.4\end{array}$

$\begin{array}{lllllllll}0.70 & 0.67 & 0.58 & 0.49 & 0.38 & 0.36 & 0.20 & 0.12\end{array}$

$\begin{array}{lllllllll}\text { JP } & 0.4 & 0.6 & 0.6 & 0.7 & 1.5 & 2.2 & 7.5 & 47.5\end{array}$

$\begin{array}{lllllllll}0.70 & 0.67 & 0.59 & 0.50 & 0.40 & 0.38 & 0.21 & 0.11\end{array}$ 
PSYCHROMETRIC MOISTURE CHARACTERISTIC CURVES

ID Suction, $\mathrm{MPa}$ (above)

Relative Saturation, dimensionless (below)

$\begin{array}{llllllllll}\text { Y3 MB } & 0.5 & 0.5 & 0.6 & 0.7 & 1.4 & 2.1 & 7.8 & 71.0\end{array}$

$\begin{array}{lllllllll}0.71 & 0.68 & 0.61 & 0.49 & 0.39 & 0.37 & 0.21 & 0.10\end{array}$

$\begin{array}{lllllllll}\text { MC } & 0.5 & 0.6 & 0.8 & 1.5 & 2.8 & 3.3 & 14.6 & 74.0\end{array}$

$\begin{array}{lllllllll}0.70 & 0.67 & 0.60 & 0.50 & 0.40 & 0.38 & 0.21 & 0.13\end{array}$

$\begin{array}{lllllllll}\text { MD } & 0.5 & 0.5 & 0.6 & 0.6 & 0.7 & 0.9 & 3.7 & 25.4\end{array}$

$\begin{array}{lllllllll}0.70 & 0.67 & 0.59 & 0.49 & 0.38 & 0.36 & 0.20 & 0.10\end{array}$

$\begin{array}{lllllll}\text { ME } & 0.4 & 0.6 & 0.8 & 2.3 & 6.9 & 26.1\end{array}$

$\begin{array}{llllll}0.60 & 0.50 & 0.38 & 0.29 & 0.18 & 0.11\end{array}$

$\begin{array}{llllllll}\text { MF } & 0.6 & 1.8 & 2.9 & 9.0 & 25.7 & 35.1\end{array}$

$\begin{array}{lllllll}0.61 & 0.46 & 0.40 & 0.29 & 0.21 & 0.15\end{array}$

MG $\quad \begin{array}{lllllll}0.6 & 0.5 & 0.9 & 1.6 & 3.1 & 8.3 & 49.9\end{array}$

$\begin{array}{lllllll}0.70 & 0.61 & 0.51 & 0.38 & 0.28 & 0.18 & 0.10\end{array}$

$\begin{array}{llllllll}\mathrm{MH} & 0.5 & 0.7 & 1.8 & 4.3 & 12.3 & 54.2\end{array}$

$\begin{array}{llllll}0.63 & 0.50 & 0.39 & 0.30 & 0.20 & 0.11\end{array}$

$\begin{array}{llllllll}\text { MJ } & 0.5 & 0.8 & 2.5 & 5.4 & 15.2 & 48.5\end{array}$

$\begin{array}{llllll}0.60 & 0.50 & 0.39 & 0.29 & 0.21 & 0.12\end{array}$

$\begin{array}{llllllll}\text { MK } & 0.5 & 0.6 & 1.2 & 4.4 & 11.5 & 47.0\end{array}$

$\begin{array}{lllllll}0.62 & 0.51 & 0.39 & 0.28 & 0.19 & 0.11\end{array}$

MM $\quad \begin{array}{lllllllll}0.5 & 0.4 & 1.3 & 3.1 & 6.4 & 27.4 & 31.6 & 61.6 & 128 .\end{array}$

$\begin{array}{llllllllll}0.69 & 0.62 & 0.48 & 0.39 & 0.31 & 0.20 & 0.18 & 0.14 & 0.11\end{array}$

$\begin{array}{lllllll}\text { MN } & 0.5 & 0.7 & 1.6 & 4.1 & 10.2 & 41.5\end{array}$

$\begin{array}{lllllll}0.64 & 0.51 & 0.40 & 0.27 & 0.20 & 0.12\end{array}$

$\begin{array}{llllllll}\text { MP } & 0.5 & 0.8 & 2.4 & 4.6 & 11.2 & 39.3\end{array}$

$\begin{array}{lllllll}0.61 & 0.50 & 0.39 & 0.30 & 0.20 & 0.12\end{array}$

$\begin{array}{lllllll}\text { MR } & 0.5 & 0.7 & 1.3 & 3.4 & 7.0 & 22.4\end{array}$

$\begin{array}{lllllll}0.62 & 0.51 & 0.37 & 0.30 & 0.20 & 0.11\end{array}$

MS $\quad \begin{array}{lllllllllll}0.5 & 0.4 & 0.9 & 2.2 & 4.6 & 17.7 & 23.0 & 43.0 & 72.9\end{array}$

$\begin{array}{llllllllll}0.68 & 0.63 & 0.47 & 0.40 & 0.31 & 0.20 & 0.17 & 0.14 & 0.12\end{array}$

$\begin{array}{lllllllllll}\text { MT } & 0.5 & 0.4 & 0.7 & 1.2 & 2.6 & 6.3 & 12.1 & 53.9 & 60.1\end{array}$

$\begin{array}{lllllllll}0.69 & 0.63 & 0.47 & 0.40 & 0.30 & 0.19 & 0.15 & 0.09 & 0.09\end{array}$

$\begin{array}{lllllllllll}\text { MU } & 1.0 & 1.3 & 2.4 & 4.0 & 7.1 & 19.4 & 24.5 & 57.4 & 77.3\end{array}$

$\begin{array}{llllllllll}0.68 & 0.63 & 0.49 & 0.40 & 0.32 & 0.20 & 0.18 & 0.13 & 0.12\end{array}$

$\begin{array}{llllllllllll}\mathrm{Z} 1 & \mathrm{~PB} & 0.4 & 0.4 & 1.6 & 2.4 & 4.6 & 17.2 & 23.1 & 62.8 & 82.8\end{array}$

$\begin{array}{lllllllllll}0.69 & 0.62 & 0.48 & 0.39 & 0.30 & 0.19 & 0.17 & 0.10 & 0.10\end{array}$

PC $\quad \begin{array}{llllllll}0.7 & 0.5 & 1.2 & 1.7 & 4.6 & 8.7 & 39.9\end{array}$

$\begin{array}{llllllll}0.68 & 0.60 & 0.48 & 0.40 & 0.29 & 0.20 & 0.09\end{array}$

$\begin{array}{lllllllllll}\text { PD } & 0.4 & 0.5 & 1.9 & 3.1 & 5.5 & 18.6 & 19.3 & 44.9 & 85.7\end{array}$

$\begin{array}{lllllllllll}0.69 & 0.63 & 0.49 & 0.39 & 0.31 & 0.19 & 0.18 & 0.14 & 0.11\end{array}$

PE

$\begin{array}{llllllll}0.6 & 0.5 & 1.3 & 1.9 & 6.5 & 12.8 & 47.0 & 70.8\end{array}$

$\begin{array}{lllllllll}0.69 & 0.59 & 0.48 & 0.40 & 0.28 & 0.21 & 0.12 & 0.10\end{array}$

$\begin{array}{lllllllll}\mathrm{PF} & 0.7 & 0.5 & 1.3 & 2.6 & 7.4 & 25.3 & 44.9 & 85.4\end{array}$

$\begin{array}{llllllllll}0.66 & 0.60 & 0.49 & 0.39 & 0.29 & 0.21 & 0.13 & 0.10\end{array}$

PG

$\begin{array}{lllllll}0.6 & 0.5 & 0.7 & 0.8 & 3.2 & 6.6 & 37.2\end{array}$

$\begin{array}{lllllll}0.68 & 0.59 & 0.48 & 0.41 & 0.28 & 0.21 & 0.10\end{array}$

$\begin{array}{llllllllll}\mathrm{PH} & 0.6 & 0.5 & 1.0 & 1.4 & 4.1 & 11.3 & 39.5 & 72.3\end{array}$

$\begin{array}{lllllllll}0.70 & 0.60 & 0.48 & 0.40 & 0.29 & 0.20 & 0.11 & 0.09\end{array}$ 
PSYCHROMETRIC MOISTURE CHARACTERISTIC CURVES

Suction; $\mathrm{MPa}$ (above)

Relative Saturation, dimensionless (below)

$\begin{array}{llllllllllll}\text { Z2 SB } & 0.5 & 0.5 & 1.0 & 1.7 & 5.0 & 14.0 & 36.9 & 66.5\end{array}$

$\begin{array}{lllllllll}0.69 & 0.70 & 0.48 & 0.40 & 0.29 & 0.20 & 0.12 & 0.10\end{array}$

$\begin{array}{lllllllllll}\mathrm{SC} & 0.6 & 0.6 & 1.8 & 2.8 & 7.6 & 22.2 & 36.1 & 93.9\end{array}$

$\begin{array}{llllllllll}0.70 & 0.60 & 0.48 & 0.40 & 0.30 & 0.21 & 0.14 & 0.09\end{array}$

$\begin{array}{llllllllll}\text { SD } & 0.6 & 0.7 & 1.5 & 2.0 & 2.8 & 10.7 & 39.0 & 70.2\end{array}$

$\begin{array}{llllllllll}0.70 & 0.60 & 0.49 & 0.40 & 0.29 & 0.20 & 0.12 & 0.10\end{array}$

SE $\quad \begin{array}{lllllllll}0.6 & 0.7 & 1.7 & 2.8 & 3.9 & 14.7 & 41.9 & 78.9\end{array}$

$\begin{array}{llllllll}0.69 & 0.60 & 0.49 & 0.39 & 0.30 & 0.19 & 0.13 & 0.10\end{array}$

SF $\quad \begin{array}{llllllll}0.6 & 0.6 & 1.1 & 2.1 & 3.2 & 9.7 & 43.2 & 81.7\end{array}$

$\begin{array}{llllllll}0.69 & 0.59 & 0.50 & 0.40 & 0.30 & 0.20 & 0.12 & 0.09\end{array}$

$\begin{array}{lllllllllll}\text { SG } & 0.7 & 0.5 & 1.7 & 2.7 & 5.1 & 16.4 & 45.3 & 76.6\end{array}$

$\begin{array}{llllllll}0.70 & 0.60 & 0.49 & 0.40 & 0.30 & 0.20 & 0.15 & 0.12\end{array}$

$\begin{array}{lllllllll}\mathrm{SH} & 0.5 & 0.5 & 1.2 & 2.6 & 4.8 & 14.2 & 44.3 & 78.8\end{array}$

$\begin{array}{llllllllll}0.70 & 0.59 & 0.50 & 0.40 & 0.30 & 0.20 & 0.14 & 0.11\end{array}$

$\begin{array}{lllllllll}\text { SJ } & 0.5 & 0.4 & 0.8 & 1.2 & 3.0 & 8.0 & 36.2 & 70.0\end{array}$

$\begin{array}{llllllllll}0.70 & 0.59 & 0.50 & 0.40 & 0.29 & 0.19 & 0.11 & 0.08\end{array}$

$\begin{array}{llllllll}\text { SK } & 0.4 & 0.4 & 0.7 & 0.9 & 2.2 & 6.1 & 33.4\end{array}$

$\begin{array}{llllllll}0.69 & 0.59 & 0.48 & 0.40 & 0.30 & 0.19 & 0.10\end{array}$

$\begin{array}{lllllllll}\text { SM } & 0.4 & 0.4 & 0.7 & 1.2 & 3.1 & 7.5 & 28.8 & 59.1\end{array}$

$\begin{array}{lllllllll}0.70 & 0.60 & 0.48 & 0.40 & 0.30 & 0.19 & 0.11 & 0.08\end{array}$

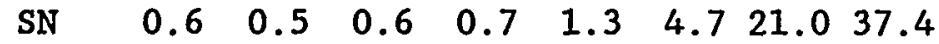

$\begin{array}{lllllllll}0.71 & 0.59 & 0.49 & 0.39 & 0.30 & 0.19 & 0.10 & 0.08\end{array}$

$\begin{array}{lllllllll}\text { SP } & 0.6 & 0.5 & 0.7 & 0.7 & 1.1 & 3.7 & 19.6 & 43.7\end{array}$

$\begin{array}{llllllllll}0.71 & 0.58 & 0.47 & 0.40 & 0.30 & 0.19 & 0.09 & 0.07\end{array}$

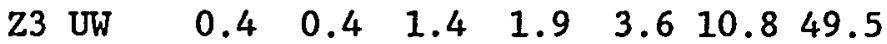

$\begin{array}{lllllllll}0.67 & 0.60 & 0.44 & 0.40 & 0.32 & 0.21 & 0.10\end{array}$

UC $\quad \begin{array}{llllllll}0.4 & 0.5 & 0.9 & 1.2 & 3.0 & 9.3 & 46.0 & 54.8\end{array}$

$\begin{array}{llllllll}0.70 & 0.60 & 0.50 & 0.41 & 0.31 & 0.20 & 0.08 & 0.08\end{array}$

UD $\quad \begin{array}{llllllllll}0.5 & 0.6 & 1.4 & 2.3 & 4.4 & 12.4 & 43.9 & 58.9\end{array}$

$\begin{array}{llllllllll}0.72 & 0.59 & 0.47 & 0.40 & 0.30 & 0.20 & 0.12 & 0.12\end{array}$

UE $\quad \begin{array}{lllllllll}0.4 & 0.5 & 0.9 & 1.6 & 3.2 & 7.4 & 43.2 & 62.2\end{array}$

$\begin{array}{lllllllll}0.70 & 0.60 & 0.50 & 0.40 & 0.28 & 0.20 & 0.11 & 0.10\end{array}$

UF $\quad \begin{array}{lllllllll}0.4 & 0.4 & 0.7 & 0.7 & 1.6 & 6.7 & 38.1 & 48.8\end{array}$

$\begin{array}{llllllllll}0.70 & 0.60 & 0.48 & 0.40 & 0.32 & 0.20 & 0.10 & 0.09\end{array}$

UG $\quad \begin{array}{lllllllll}0.4 & 0.5 & 0.7 & 1.1 & 3.1 & 7.0 & 33.7 & 51.8\end{array}$

$\begin{array}{llllllll}0.71 & 0.59 & 0.49 & 0.39 & 0.29 & 0.20 & 0.09 & 0.09\end{array}$

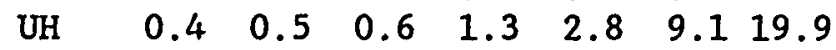

$\begin{array}{lllllll}0.69 & 0.59 & 0.49 & 0.37 & 0.30 & 0.18 & 0.10\end{array}$

UJ $\quad \begin{array}{llllllll}0.4 & 0.5 & 0.6 & 1.0 & 2.4 & 8.0 & 23.8\end{array}$

$\begin{array}{lllllll}0.70 & 0.60 & 0.49 & 0.38 & 0.31 & 0.18 & 0.10\end{array}$

$\begin{array}{lllllllll}\text { UK } & 0.4 & 0.5 & 0.5 & 0.7 & 1.0 & 5.7 & 19.0\end{array}$

$\begin{array}{llllllll}0.69 & 0.58 & 0.49 & 0.36 & 0.30 & 0.16 & 0.08\end{array}$

$\begin{array}{llllllll}\text { UM } & 0.4 & 0.5 & 0.5 & 0.6 & 1.2 & 5.0 & 17.4\end{array}$

$\begin{array}{llllllll}0.70 & 0.59 & 0.48 & 0.39 & 0.30 & 0.20 & 0.10\end{array}$

$\begin{array}{llllllll}\text { UN } & 0.3 & 0.5 & 0.5 & 1.2 & 1.6 & 8.2 & 23.7\end{array}$

$\begin{array}{llllllll}0.69 & 0.59 & 0.50 & 0.36 & 0.32 & 0.20 & 0.10\end{array}$ 
Table A9b (Continued)

ID

PSYCHROMETRIC MOISTURE CHARACTERISTIC CURVES

Suction, $\mathrm{MPa}$ (above)

Relative Saturation, dimensionless (below)

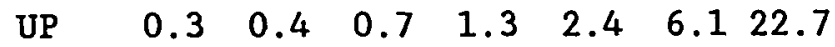

$\begin{array}{llllllll}0.69 & 0.59 & 0.50 & 0.38 & 0.32 & 0.23 & 0.11\end{array}$

$\begin{array}{llllllll}\text { UR } & 0.3 & 0.4 & 0.7 & 0.8 & 1.4 & 4.5 & 15.8\end{array}$

$\begin{array}{lllllllll}0.73 & 0.59 & 0.50 & 0.38 & 0.31 & 0.21 & 0.09\end{array}$

US $\quad \begin{array}{lllllllll}0.3 & 0.4 & 0.6 & 0.6 & 0.8 & 1.4 & 3.6 & 5.7\end{array}$

$\begin{array}{llllllll}0.70 & 0.60 & 0.49 & 0.38 & 0.30 & 0.20 & 0.09 & 0.08\end{array}$

$\begin{array}{llllllll}\text { UT } & 0.4 & 0.4 & 0.5 & 0.8 & 2.5 & 5.5 & 23.0\end{array}$

$\begin{array}{lllllll}0.71 & 0.60 & 0.50 & 0.43 & 0.31 & 0.21 & 0.11\end{array}$

UU $\quad \begin{array}{llllllll}0.4 & 0.4 & 0.6 & 0.7 & 2.1 & 4.7 & 22.8\end{array}$

$\begin{array}{lllllll}0.69 & 0.60 & 0.50 & 0.41 & 0.40 & 0.19 & 0.09\end{array}$ 
Table A9c: Laboratory moisture characteristic curves for 105 large core segments as a function of matric suction using Tempe Pressure cells.

ID

TEMPE PRESSURE CELL MOISTURE CHARACTERISTIC CURVES

\begin{tabular}{|c|c|c|c|c|}
\hline $\begin{array}{l}A A \\
A B \\
A C \\
A D \\
A E \\
A F \\
A G\end{array}$ & $\begin{array}{l}95.80 \\
97.10 \\
96.43 \\
96.65 \\
97.34 \\
98.70 \\
99.21\end{array}$ & $\begin{array}{l}85.85 \\
88.62 \\
89.06 \\
92.35 \\
94.87 \\
97.82 \\
97.60\end{array}$ & $\begin{array}{l}78.58 \\
78.53 \\
76.62 \\
82.27 \\
84.61 \\
93.01 \\
94.99\end{array}$ & $\begin{array}{l}63.66 \\
64.00 \\
63.42 \\
66.78 \\
67.79 \\
78.60 \\
74.16\end{array}$ \\
\hline $\begin{array}{l}C A \\
C B \\
C C \\
C D \\
C E \\
C F \\
C G \\
C H \\
C J \\
C K \\
C M \\
C N\end{array}$ & $\begin{array}{l}84.53 \\
93.23 \\
89.56 \\
98.04 \\
98.94 \\
99.07 \\
98.77 \\
98.67 \\
99.28 \\
99.21 \\
98.99 \\
99.72\end{array}$ & $\begin{array}{l}72.17 \\
87.20 \\
81.41 \\
95.06 \\
97.10 \\
93.98 \\
94.85 \\
92.52 \\
98.74 \\
98.57 \\
97.81 \\
98.00\end{array}$ & $\begin{array}{l}64.20 \\
78.36 \\
74.33 \\
87.36 \\
88.00 \\
82.31 \\
85.25 \\
77.72 \\
93.03 \\
93.15 \\
86.37 \\
95.96\end{array}$ & $\begin{array}{l}54.66 \\
64.06 \\
61.40 \\
73.34 \\
69.79 \\
67.63 \\
65.00 \\
56.41 \\
67.77 \\
67.68 \\
65.71 \\
71.39\end{array}$ \\
\hline $\begin{array}{l}\text { EA } \\
\text { EB } \\
\text { EC } \\
\text { ED } \\
\text { EE } \\
\text { EF } \\
\text { EG } \\
\text { EH } \\
\text { EJ } \\
\text { ER } \\
\text { EM } \\
\text { EN } \\
\text { EP } \\
\text { ER } \\
\text { ES } \\
\text { ET }\end{array}$ & $\begin{array}{l}98.43 \\
91.78 \\
91.31 \\
93.69 \\
97.34 \\
99.33 \\
99.02 \\
99.44 \\
95.78 \\
99.23 \\
99.55 \\
98.72 \\
99.77 \\
98.18 \\
99.43 \\
99.52\end{array}$ & $\begin{array}{l}96.38 \\
86.71 \\
85.61 \\
87.36 \\
95.03 \\
98.52 \\
98.46 \\
99.16 \\
95.18 \\
98.66 \\
99.41 \\
97.91 \\
99.00 \\
97.63 \\
99.07 \\
97.45\end{array}$ & $\begin{array}{l}82.04 \\
76.91 \\
75.49 \\
78.07 \\
83.19 \\
89.69 \\
91.72 \\
93.24 \\
92.44 \\
95.99 \\
97.74 \\
95.90 \\
97.12 \\
95.07 \\
97.97 \\
95.95\end{array}$ & $\begin{array}{l}64.71 \\
64.09 \\
60.94 \\
60.22 \\
65.62 \\
70.02 \\
70.00 \\
66.61 \\
68.36 \\
73.98 \\
74.76 \\
75.80 \\
72.69 \\
71.32 \\
83.37 \\
75.71\end{array}$ \\
\hline
\end{tabular}


Table A9c (Continued) ID

TEMPE PRESSURE CELL MOISTURE CHARACTERISTIC CURVES

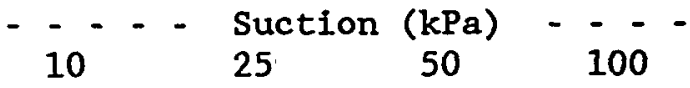

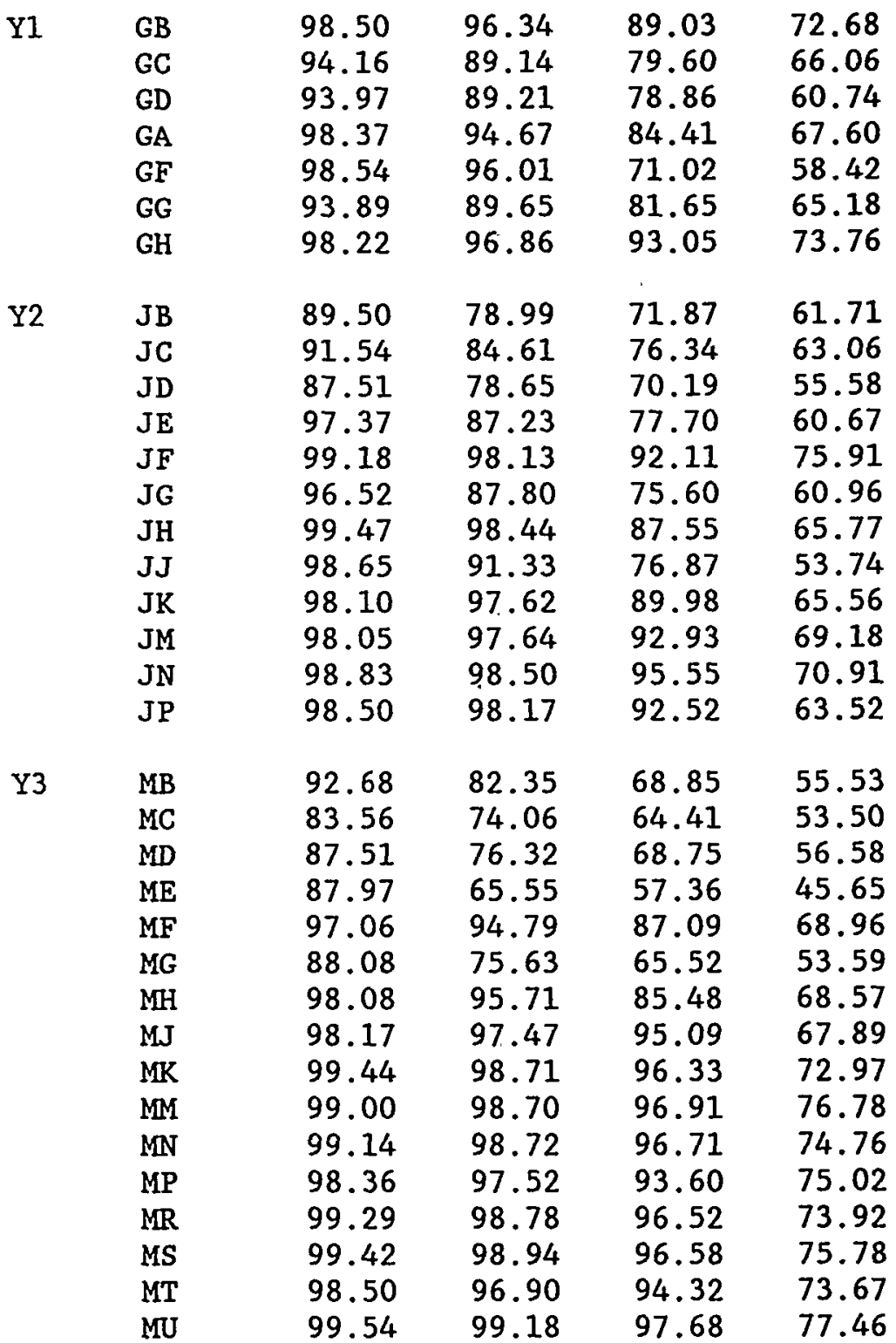


ID

TEMPE PRESSURE CELL MOISTURE CHARACTERISTIC CURVES

$\begin{array}{llllll}21 & & & & \\ & \text { PB } & 93.85 & 85.88 & 76.83 & 62.35 \\ & \text { PC } & 97.07 & 90.07 & 79.86 & 63.55 \\ & \text { PD } & 89.75 & 81.79 & 74.51 & 58.29 \\ & \text { PE } & 94.98 & 88.26 & 81.77 & 65.00 \\ & \text { PF } & 96.87 & 94.18 & 86.57 & 66.41 \\ & \text { PG } & 97.96 & 86.93 & 73.95 & 57.02 \\ & \text { PH } & 97.18 & 94.94 & 86.44 & 64.78 \\ & & & & & \\ & \text { SB } & 94.32 & 90.51 & 81.65 & 67.31 \\ & \text { SC } & 94.21 & 90.19 & 83.94 & 68.33 \\ & \text { SD } & 97.18 & 88.68 & 80.19 & 63.61 \\ & \text { SE } & 97.88 & 90.63 & 81.68 & 66.98 \\ & \text { SF } & 94.55 & 86.19 & 77.33 & 62.67 \\ & \text { SG } & 95.57 & 80.40 & 66.02 & 42.50 \\ & \text { SH } & 97.26 & 93.52 & 84.88 & 66.04 \\ & \text { SJ } & 99.11 & 98.20 & 91.44 & 66.45 \\ & \text { SK } & 99.92 & 99.46 & 97.19 & 66.62 \\ & \text { SM } & 99.27 & 98.61 & 94.65 & 73.59 \\ & \text { SN } & 97.11 & 96.64 & 93.94 & 67.39 \\ & \text { SP } & 99.42 & 98.94 & 93.99 & 67.25 \\ & & & & & \\ \text { Z3 } 3 & & & \\ & \text { UW } & 97.35 & 95.12 & 86.68 & 69.36 \\ & \text { UC } & 95.98 & 87.78 & 76.49 & 59.72 \\ & \text { UD } & 89.21 & 79.90 & 66.49 & 52.16 \\ & \text { UE } & 96.55 & 86.66 & 79.48 & 65.11 \\ & \text { UF } & 98.96 & 96.99 & 86.54 & 71.73 \\ & \text { UG } & 99.22 & 94.71 & 87.40 & 61.15 \\ & \text { UH } & 98.90 & 88.88 & 74.99 & 50.91 \\ & \text { UJ } & 98.76 & 98.06 & 93.50 & 68.18 \\ & \text { UK } & 96.76 & 95.82 & 93.03 & 68.40 \\ & \text { UM } & 98.17 & 97.24 & 93.11 & 71.05 \\ & \text { UN } & 99.47 & 99.14 & 95.98 & 72.05 \\ & \text { UP } & 99.51 & 98.86 & 96.70 & 72.53 \\ \text { UR } & 99.18 & 98.70 & 93.59 & 64.49 \\ & \text { US } & 99.56 & 99.04 & 96.31 & 74.07 \\ & \text { UT } & 99.40 & 98.90 & 95.85 & 71.13 \\ \text { UU } & 99.15 & 98.70 & 96.09 & 72.86\end{array}$


Table A9d: Laboratory moisture characteristic curves for 10 large core segments as a function of matric suction for wetting phase.

\begin{tabular}{lccccccc}
\multicolumn{7}{c}{ RELATIVE SATURATION (8) } \\
& $-\quad-$ & \multicolumn{7}{c}{ Matric Suction $(\mathrm{kPa})$} & - & - \\
& 10 & 25 & 50 & 100 & 300 & 500 \\
EC & 70.14 & 63.23 & 56.32 & 52.60 & 47.82 & 46.76 \\
EN & 75.90 & 70.10 & 60.83 & 48.67 & 39.98 & 38.82 \\
GG & 61.40 & 57.64 & 49.50 & 42.61 & 35.09 & 32.58 \\
JK & 70.41 & 66.27 & 56.21 & 46.15 & 38.46 & 36.69 \\
MJ & 76.98 & 75.60 & 65.98 & 54.30 & 42.61 & 41.24 \\
PF & 73.25 & 69.33 & 64.09 & 57.55 & 50.36 & 49.05 \\
PG & 77.19 & 70.23 & 62.10 & 56.88 & 49.91 & 48.17 \\
SA & 70.25 & 68.35 & 57.60 & 45.57 & 37.34 & 35.44 \\
SD & 67.58 & 62.83 & 57.50 & 52.76 & 46.24 & 45.64 \\
UA & 84.85 & 81.21 & 72.12 & 57.58 & 38.79 & 36.36
\end{tabular}


Table A9e: Van Genuchten moisture characteristic curve function parameters. Least squares estimate using relative saturation. objective function and a constant $n$-value for all samples. Optimal parameter estimates obtained when residual saturation is zero and when the n-parameter is equal to 1.26 .

\begin{tabular}{|c|c|c|c|c|c|c|c|c|}
\hline & ID & $\begin{array}{r}\alpha \text {-value } \\
\left(\mathrm{kPa}^{-1}\right)\end{array}$ & & ID & $\begin{array}{r}\alpha \text {-value } \\
\left(\mathrm{kPa}^{-1}\right)\end{array}$ & & ID & $\begin{array}{r}\alpha \text {-value } \\
\left(\mathrm{kPa}^{-1}\right)\end{array}$ \\
\hline \multirow[t]{7}{*}{$\mathrm{X} 1$} & $A A$ & .0289 & $\mathrm{Y} 1$ & GB & .0150 & Z1 & PB & .0234 \\
\hline & $A B$ & .0289 & & GC & .0194 & & PC & .0234 \\
\hline & AC & .0157 & & GD & .0234 & & PD & .0220 \\
\hline & $A D$ & .0154 & & GA & .0200 & & $\mathrm{PE}$ & .0173 \\
\hline & $\mathrm{AE}$ & .0177 & & GF & .0430 & & $\mathrm{PF}$ & .0182 \\
\hline & $\mathrm{AF}$ & .0240 & . & GG & .0323 & & PG & .0297 \\
\hline & AG & .0176 & & GH & .0201 & & $\mathrm{PH}$ & .0193 \\
\hline \multirow[t]{12}{*}{$\mathrm{x} 2$} & $\mathrm{CA}$ & .0331 & Y2 & JB & .0394 & $\mathrm{z} 2$ & SB & .0257 \\
\hline & $C B$ & .0164 & & $\mathrm{JC}$ & .0153 & & SC & .0177 \\
\hline & CC & .0102 & & JD & .0412 & & SD & .0179 \\
\hline & $C D$ & .0125 & & $\mathrm{JE}$ & .0184 & & SE & .0192 \\
\hline & $\mathrm{CE}$ & .0110 & & JF & .0205 & & SF & .0216 \\
\hline & CF & .0156 & & JG & .0238 & & SG & .0311 \\
\hline & CG & .0176 & & JH & .0333 & & SH & .0182 \\
\hline & $\mathrm{CH}$ & .0284 & & JJ & .0329 & & SJ & .0258 \\
\hline & CJ & .0284 & & $\mathrm{JK}$ & .0263 & & SK & .0198 \\
\hline & CK & .0257 & & JM & .0215 & & SM & 0171 \\
\hline & CM & .0240 & & JN & .0184 & & SN & .0200 \\
\hline & $\mathrm{CN}$ & .0219 & & JP & .0186 & & SP & .0200 \\
\hline \multirow[t]{16}{*}{$\mathrm{X3}$} & EA & .0203 & Y3 & MB & .0256 & 23 & UW & .0212 \\
\hline & EB & .0139 & & MC & .0256 & & UC & .0316 \\
\hline & EC & .0176 & & MD & .0314 & & UD & .0514 \\
\hline & ED & .0161 & & ME & .0643 & & UE & .0431 \\
\hline & EE & .0217 & & MF & .0126 & & UF & .0279 \\
\hline & EF & .0124 & & MG & .0297 & & UG & .0325 \\
\hline & EG & .0167 & & MH & .0218 & & $\mathrm{UH}$ & .0312 \\
\hline & EH & .0208 & & MJ & .0196 & & UJ & .0205 \\
\hline & EJ & .0172 & & MK & .0161 & & UK & .0244 \\
\hline & EK & .0127 & & MM & .0120 & & UM & .0238 \\
\hline & EM & .0136 & & MN & .0158 & & UN & .0205 \\
\hline & EN & .0168 & & MP & .0205 & & UP & .0146 \\
\hline & EP & .0221 & & MR & .0246 & & UR & .0232 \\
\hline & ER & .0183 & & MS & .0195 & & US & .0233 \\
\hline & ES & .0135 & & MT & .0195 & & UT & .0182 \\
\hline & ET & .0135 & & MU & .0130 & & UU & .0202 \\
\hline
\end{tabular}


Table A10: Laboratory determined unsaturated hydraulic conductivity values in $\mathrm{m} / \mathrm{s} \times \mathrm{E}-9$ for large core segments obtained using outflow method.

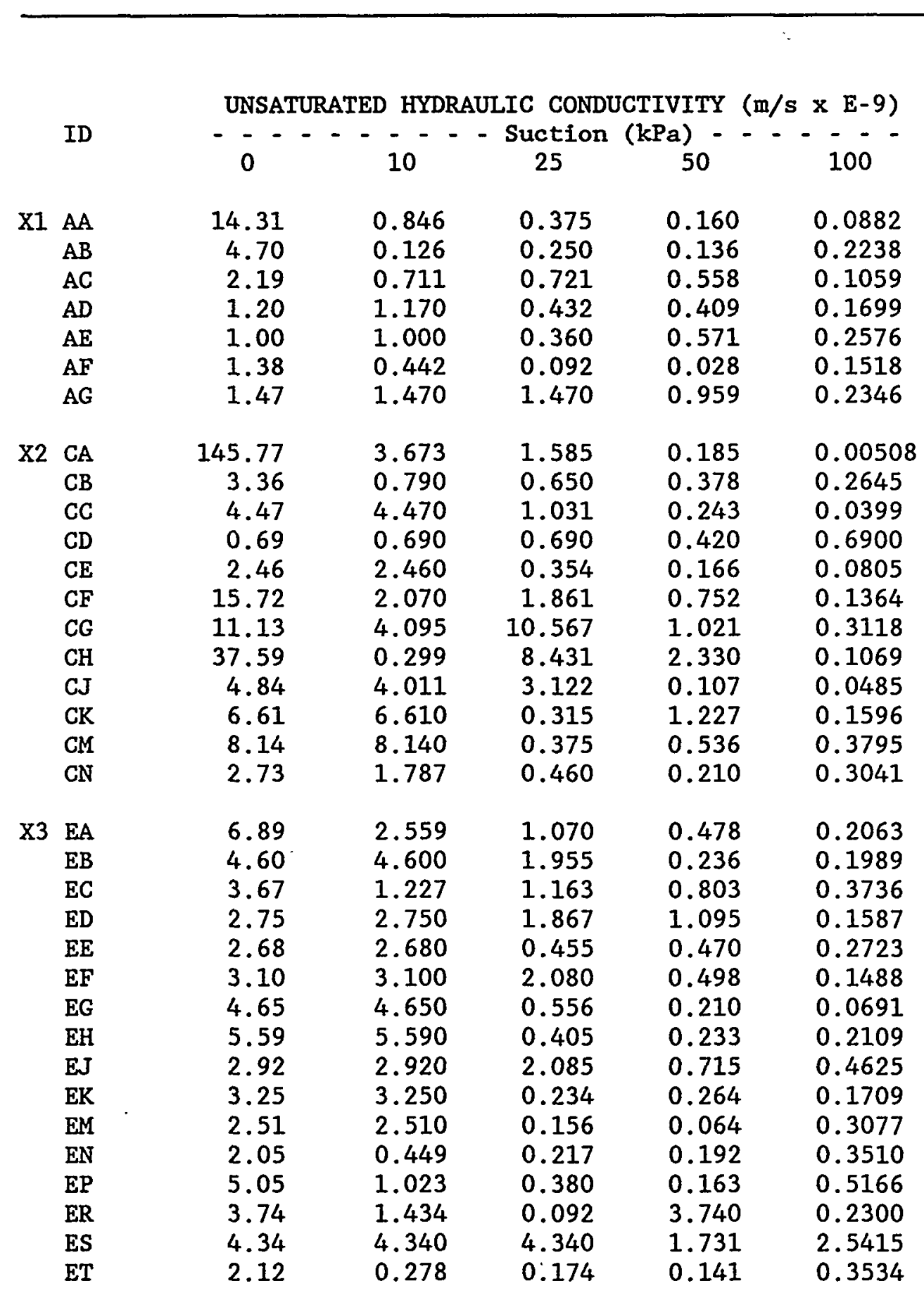


UNSATURATED HYDRAULIC CONDUCTIVITY (m/s $\times$ E-9)

ID

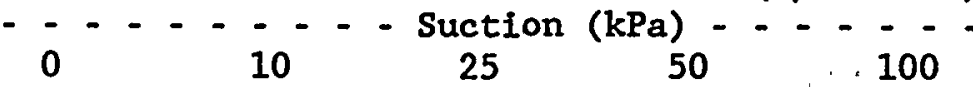

Y1 GB

1.73

0.535

0.514

0.168

0.1536

GC

4.61

0.189

0.127

0.184

0.0949

GD

3.58

0.597

0.521

0.177

0.0907

1.11

1.110

0.815

0.760

0.0957

GF

1.02

1.020

0.293

1.020

0.9870

GG

1.44

1.425

0.335

0.183

0.0742

2.40

2.357

1.282

1.048

0.5110

Y2 JB

16.12

1.607

0.550

0.229

0.0564

JC

17.94

7.434

0.540

0.216

2.22

1.091

0.339

0.305

0.0257

$2.88^{\circ}$

2.880

0.409

0.307

0.2114

2.00

2.000

0.119

0.527

0.4648

10.95

10.950

0.699

0.187

0.1249

3.63

2.792

0.811

0.506

0.0227

82.65

5.234

9.182

2.575

0.1993

4.20

4.098

3.670

1.306

0.5986

4.25

2.429

1.894

0.0949

3.54

3.540

1.843

3.540

0.3991

4.66

4.660

4.660

4.097

0.1038

Y3 MB

5.76

2.847

5.760

0.528

1.0341

MC

10.54

10.540

1.737

0.242

0.2047

31.25

9.478

0.930

0.352

0.1859

$M E$

MF

239.74

1.753

0.277

0.00184

0.0684

1.40

1.400

0.648

0.885

0.0074

438.28

7. 359

2.286

1.940

0.2650

13.34

3.879

0.374

2.236

0.2981

3.69

3.690

0.401

0.847

0.1097

4.24

4.240

0.011

2.711

0.5181

2.63

2.630

0.323

1.370

0.5694

4.22

4.220

0.966

1.639

0.6896

3.64

0.170

0.097

1.186

0.3809

2.06

2.060

0.094

1.809

0.6614

3.94

0.812

0.356

0.199

1.4109

4.01

4.010

0.691

0.437

0.1695

1.44

1.440

0.461

0.370

0.2827

0.1932 
Table A10 (Continued)

ID

UNSATURATED HYDRAULIC CONDUCTIVITY (m/s $\times$ E-9)

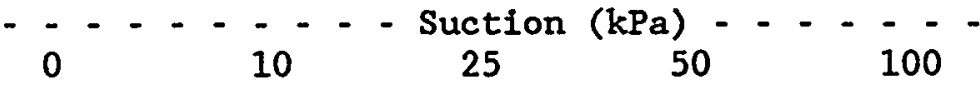

$21 \mathrm{~PB}$

5.49

3.49

103.57

4.50

2.39

25.75

2.61

5.490

1.643

3.388

2.897

16.229

1.398

1.659

1.095

2. 390

0.532

6.371

0.528

0.4268

PG

PH

25.750

0.628

0.469

0.2132

0.236

0.0437

0.891

0.2635

2.610

1.414

0.2858

1.44

Z2 SB

$S C$

SD

SE

SF

SG

$\mathrm{SH}$

SJ

SK

SM

SN

SP

23 UW

UC

UD

UE

UF

UG

$\mathrm{UH}$

UJ

UK

UM

UN

UP

UR

US

UT

UU

$$
2.99
$$

16.47

4.78

54.49

376.17

9.67

4.27

3.50

2.09

4.47

8.14

1.440

0.359

0.268

0.8799

0.1354

0.323

0.294

0.338

0.3361

3.063

0.621

0.161

0.0791

0.442

0.383

0.240

0.0358

1.040

0.834

0.361

0.3255

10.138

6.816

0.515

0.4933

6.543

2.007

5.041

0.8742

4.270

0.381

0.996

0.2339

0.166

3.500

0.597

0.2234

2.090

0.528

3.500

0.3392

0.626

0.463

0.413

1.0544

8.140

3.792

4.470

0.4277

1.34

6.55

189.79

51.95

2.36

15.70

19.84

4.07

1.340

0.980

3.773

1.6687

3.31

0.437

0.507

1.671

0.511

0.481

0.2437

1.129

0.144

0.418

0.1690

0.381

0.160

0.00656

0.0174

0.699

0.880

0.125

0.1230

0.262

14.588

0.196

0.0622

4.070

0.656

0.614

0.3616

3.310

0.288

1.091

0.2377

4.83

4.830

0.071

2.650

0.1653

4.82

4.820

1.178

0.158

0.2913

3.72

3.720

0.383

2.051

1.2390

6.22

6.220

0.112

0.623

2.0692

5.69

5.690

2.512

0.314

0.7607

6.14

6.140

2.174

0.206

0.3884

4.31

4.310

1.823

0.9150

0.7153

1.158

0.4590 
Table All: Field determined saturated hydraulic conductivity values in $\mathrm{m} / \mathrm{s}$ $x$ E-9 at the Apache Leap Tuff Site using three methods: (1) Philip, (2) Glover, and (3) Dachler.

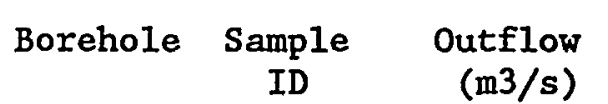

$\mathrm{X} 1$

$\begin{array}{ll}\mathrm{AA} & - \\ \mathrm{AB} & - \\ \mathrm{AC} & 0.083 \\ \mathrm{AD} & 0.016 \\ \mathrm{AE} & 0.183 \\ \mathrm{AF} & 0.083 \\ \mathrm{AG} & 0.167\end{array}$

$\mathrm{X} 2$

$\begin{array}{lc}\mathrm{CA} & - \\ \mathrm{CB} & - \\ \mathrm{CC} & 1.567 \\ \mathrm{CD} & 0.250 \\ \mathrm{CE} & 0.267 \\ \mathrm{CF} & 2.016 \\ \mathrm{CG} & 1.816 \\ \mathrm{CH} & 0.967 \\ \mathrm{CJ} & 1.616 \\ \mathrm{CK} & 0.283 \\ \mathrm{CM} & 0.783 \\ \mathrm{CN} & 0.216\end{array}$

$\mathrm{x} 3$
Hydraulic Conductivity (m/s x E-9) - - - Method - - -
(1)
(2)
(3)

$\begin{array}{ccc}- & - & - \\ - & - & - \\ 5.50 & 2.94 & 5.16 \\ 0.68 & 0.36 & 0.62 \\ 5.45 & 2.91 & 5.17 \\ 1.94 & 1.04 & 1.84 \\ 1.99 & 1.14 & 1.88\end{array}$

\begin{tabular}{rrr}
- & \multicolumn{1}{c}{-} & \multicolumn{1}{c}{-} \\
120.31 & 57.92 & 100.74 \\
11.63 & 5.62 & 9.82 \\
8.96 & 4.33 & 7.58 \\
53.04 & 25.65 & 44.81 \\
39.25 & 18.98 & 33.16 \\
17.73 & 8.57 & 14.99 \\
25.74 & 12.45 & 21.75 \\
3.98 & 1.92 & 3.37 \\
9.87 & 4.77 & 8.34 \\
1.89 & 0.96 & 1.53
\end{tabular}

$\begin{array}{ccc}- & & - \\ - & - & - \\ 45.66 & 20.23 & 35.16 \\ 56.04 & 24.82 & 43.14 \\ 29.14 & 12.91 & 22.44 \\ 9.06 & 4.01 & 6.97 \\ 1.57 & 0.69 & 1.21 \\ 7.66 & 3.39 & 5.90 \\ 4.64 & 2.05 & 3.57 \\ 11.02 & 4.88 & 8.47 \\ 2.53 & 1.12 & 1.94 \\ 6.45 & 2.86 & 4.96 \\ 4.37 & 1.94 & 3.37 \\ - & - & - \\ - & - & - \\ 0.48 & 0.27 & 0.41\end{array}$


Table A11 (Continued)

$\begin{array}{cc}\text { Borehole Sample } & \text { Outflow } \\ \text { ID } & (\mathrm{m} 3 / \mathrm{s})\end{array}$

Y1

$\begin{array}{lc}\text { GB } & - \\ \text { GC } & - \\ \text { GD } & 0.116 \\ \text { GA } & 0.066 \\ \text { GF } & 0.083 \\ \text { GG } & 0.100 \\ \text { GH } & 0.100\end{array}$

$\mathrm{Y} 2$

$\begin{array}{ll}\text { JB } & - \\ \text { JC } & - \\ \text { JD } & 1.216 \\ \text { JE } & 0.250 \\ \text { JF } & 0.300 \\ \text { JG } & 0.967 \\ \text { JH } & 3.933 \\ \text { JJ } & 1.616 \\ \text { JK } & 1.150 \\ \text { JM } & 0.516 \\ \text { JN } & 0.350 \\ \text { JP } & 0.283\end{array}$

Y3

Hydraulic Conductivity (m/s x E-9)

(1)

$$
\text { Method }
$$

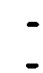

8.02

2.76

2.49

2.33

1.97

(3)

\begin{tabular}{rrr}
- & \multicolumn{1}{c}{} \\
- & \multicolumn{1}{c}{-} & \multicolumn{1}{c}{-} \\
106.52 & 51.44 & 93.75 \\
11.68 & 5.83 & 10.70 \\
10.02 & 5.00 & 9.18 \\
25.12 & 12.55 & 23.03 \\
83.63 & 41.78 & 76.65 \\
29.08 & 14.53 & 26.65 \\
17.94 & 8.96 & 16.44 \\
7.11 & 3.55 & 6.51 \\
4.31 & 2.15 & 3.95 \\
4.64 & 2.15 & 2.73
\end{tabular}

\begin{tabular}{rcr}
- & \multicolumn{1}{c}{} & \multicolumn{1}{c}{-} \\
73.17 & 34.09 & \multicolumn{1}{c}{59.32} \\
27.32 & 13.16 & 23.98 \\
60.49 & 29.15 & 53.09 \\
63.31 & 30.51 & 55.58 \\
45.25 & 21.80 & 39.72 \\
8.10 & 3.90 & 7.11 \\
6.76 & 3.26 & 5.92 \\
10.02 & 4.83 & 8.80 \\
6.62 & 3.19 & 5.81 \\
11.78 & 5.68 & 10.34 \\
3.88 & 1.87 & 3.41 \\
3.41 & 1.64 & 3.00 \\
1.96 & 0.94 & 1.71 \\
1.03 & 0.53 & 0.78
\end{tabular}




$$
\begin{array}{ccc}
\text { Borehole } & \begin{array}{c}
\text { Sample } \\
\text { ID }
\end{array} & \begin{array}{c}
\text { Outflow } \\
(\mathrm{m} 3 / \mathrm{s})
\end{array}
\end{array}
$$

Z1

$$
\begin{array}{lc}
\text { PB } & - \\
\text { PC } & - \\
\text { PD } & 2.216 \\
\text { PE } & 1.100 \\
\text { PF } & 26.050 \\
\text { PG } & 4.716 \\
\text { PH } & 1232.0
\end{array}
$$

$\mathbf{z 2}$

$$
\begin{array}{lc}
\text { SB } & - \\
\text { SC } & - \\
\text { SD } & 0.067 \\
\text { SE } & \cdot \\
\text { SF } & 0.083 \\
\text { SG } & 1.600 \\
\text { SH } & 7.516 \\
\text { SJ } & 2.867 \\
\text { SK } & 9.416 \\
\text { SM } & 6.583 \\
\text { SN } & 2.483 \\
\text { SP } & 1.067 \\
& 0.633
\end{array}
$$

23
Hydraulic Conductivity (m/s x E-9)

$$
\text { (1) (2) (3) }
$$

$\begin{array}{ccc}- & - & - \\ - & - & - \\ 182.53 & 95.90 & 172.17 \\ 47.37 & 25.75 & 47.97 \\ 797.56 & 433.59 & 807.79 \\ 71.45 & 41.51 & 113.46 \\ 39224 . & 19126 . & 17900 .\end{array}$

\begin{tabular}{rrr}
- & \multicolumn{1}{c}{-} & \multicolumn{1}{c}{-} \\
5.74 & - & - \\
4.00 & 2.76 & 5.06 \\
54.81 & 1.96 & 3.58 \\
200.09 & 98.01 & 49.21 \\
62.41 & 30.57 & 179.68 \\
173.38 & 84.93 & 155.05 \\
105.03 & 51.45 & 94.33 \\
34.95 & 17.12 & 31.39 \\
13.43 & 6.58 & 12.07 \\
8.91 & 4.19 & 5.91
\end{tabular}

$\begin{array}{ccc}- & - & - \\ - & - & - \\ 14.11 & 6.75 & 12.34 \\ 11.78 & 5.64 & 10.33 \\ 22.11 & 10.59 & 19.39 \\ 25.73 & 12.32 & 22.55 \\ 42.63 & 20.42 & 37.39 \\ 14.84 & 7.11 & 13.01 \\ 6.71 & 3.21 & 5.88 \\ 28.69 & 13.74 & 25.17 \\ 73.95 & 35.42 & 64.86 \\ 10.82 & 5.67 & 14.45 \\ - & - & - \\ - & - & - \\ 6947.9 & 3435.8 & 4234.0 \\ 8.38 & 4.46 & 6.87\end{array}$


Table A12: Outflow rates during borehole flooding experiments.

Borehole X1

$\begin{array}{ccc}\begin{array}{c}\text { Elapsed Time } \\ \text { (hours) }\end{array} & \begin{array}{c}\text { Outflow } \\ \text { (liters/hr) }\end{array} & \text { Comments } \\ 0.00 & \text { NA } & \text { Borehole filled, head between }-4 \&-1 \mathrm{~m} . \\ 104.20 & 1.60 & \\ 114.12 & 0.88 & \\ 151.40 & 1.38 & \\ 163.15 & 1.92 & \\ 171.07 & 1.93 & \\ 220.82 & 1.38 & \\ 245.48 & 1.46 & \\ 259.77 & 1.78 & \\ 370.05 & 1.63 & \\ 380.33 & 1.67 & \text { Head at +0.5 m beginning } 415 \text { hrs. } \\ 386.47 & 2.00 & \text { Borehole drained } \\ 416.17 & 3.39 & \end{array}$




\section{Borehole X2}

$\begin{array}{rcc}\begin{array}{c}\text { Elapsed Time } \\ \text { (hours) }\end{array} & \begin{array}{c}\text { Outflow } \\ \text { (1iters/hr) }\end{array} & \text { Comments } \\ 0.00 & \text { NA } & \text { Borehole filled, head at } 0.5 \mathrm{~m} . \\ 26.25 & 31.56 & \text { Siphon reestablished. } \\ 31.00 & 44.76 & \\ 42.75 & 42.72 & \\ 72.75 & 41.46 & \\ 79.00 & 42.00 & \\ 91.25 & 41.34 & \\ 97.50 & 41.58 & \\ 100.25 & 41.76 & \\ 115.25 & 41.52 & \\ 152.67 & 41.10 & \\ 164.25 & 40.50 & \\ 171.83 & 40.44 & \\ 222.00 & 38.76 & \\ 246.00 & 37.62 & \\ 262.50 & 38.82 & \text { Siphon reestablished. } \\ 283.33 & 37.80 & \\ 363.25 & 35.58 & \\ 383.17 & 36.72 & \text { Siphon reestablished. } \\ 416.83 & 36.84 & \\ 458.83 & 34.68 & \text { Borehole drained. }\end{array}$


Borehole Y1

$\begin{array}{rcc}\begin{array}{c}\text { Elapsed Time } \\ \text { (hours) }\end{array} & \begin{array}{c}\text { Outflow } \\ \text { (1iters/hr) }\end{array} & \text { Comments } \\ 0.00 & \text { NA } & \text { Borehole filled, head between }-4 \text { \& }-1 \mathrm{~m} . \\ 99.32 & 0.87 & \\ 114.00 & 0.90 & \\ 151.08 & 0.80 & \\ 164.90 & 0.40 & \\ 170.30 & 1.00 & \\ 220.43 & 0.77 & \\ 245.08 & 0.79 & \\ 259.60 & 0.91 & \\ 369.30 & 0.72 & \\ 379.77 & 0.71 & \\ 385.92 & 0.86 & \text { Head at +0.5 m beginning } 415 \text { hrs. } \\ 415.83 & 1.27 & \text { Borehole drained. } \\ 452.17 & 1.27 & \end{array}$


Borehole Y2

$\begin{array}{rcc}\begin{array}{c}\text { Elapsed Time } \\ \text { (hours) }\end{array} & \begin{array}{c}\text { Outflow } \\ \text { (liters/hr) }\end{array} & \text { Comments } \\ 0.00 & \mathrm{NA} & \text { Borehole filled, head at } 0.5 \mathrm{~m} . \\ 26.00 & 35.10 & \\ 31.50 & 39.42 & \text { Siphon reestablished. } \\ 42.00 & 37.26 & \\ 72.00 & 33.72 & \\ 78.75 & 33.90 & \\ 91.00 & 33.06 & \\ 97.25 & 32.82 & \\ 100.00 & 33.36 & \text { Siphon reestablished. } \\ 115.00 & 32.94 & \\ 152.25 & 32.10 & \\ 164.00 & 31.20 & \\ 171.58 & 31.14 & \\ 221.75 & 29.46 & \\ 246.00 & 28.56 & \\ 260.50 & 28.20 & \\ 262.25 & 28.92 & \text { Siphon reestablished. } \\ 283.17 & 27.66 & \\ 363.75 & 21.06 & \\ 383.00 & 27.72 & \text { Siphon reestablished. } \\ 416.50 & 26.40 & \end{array}$


Table A13: Field volumetric water content in percent determined from neutron count data.

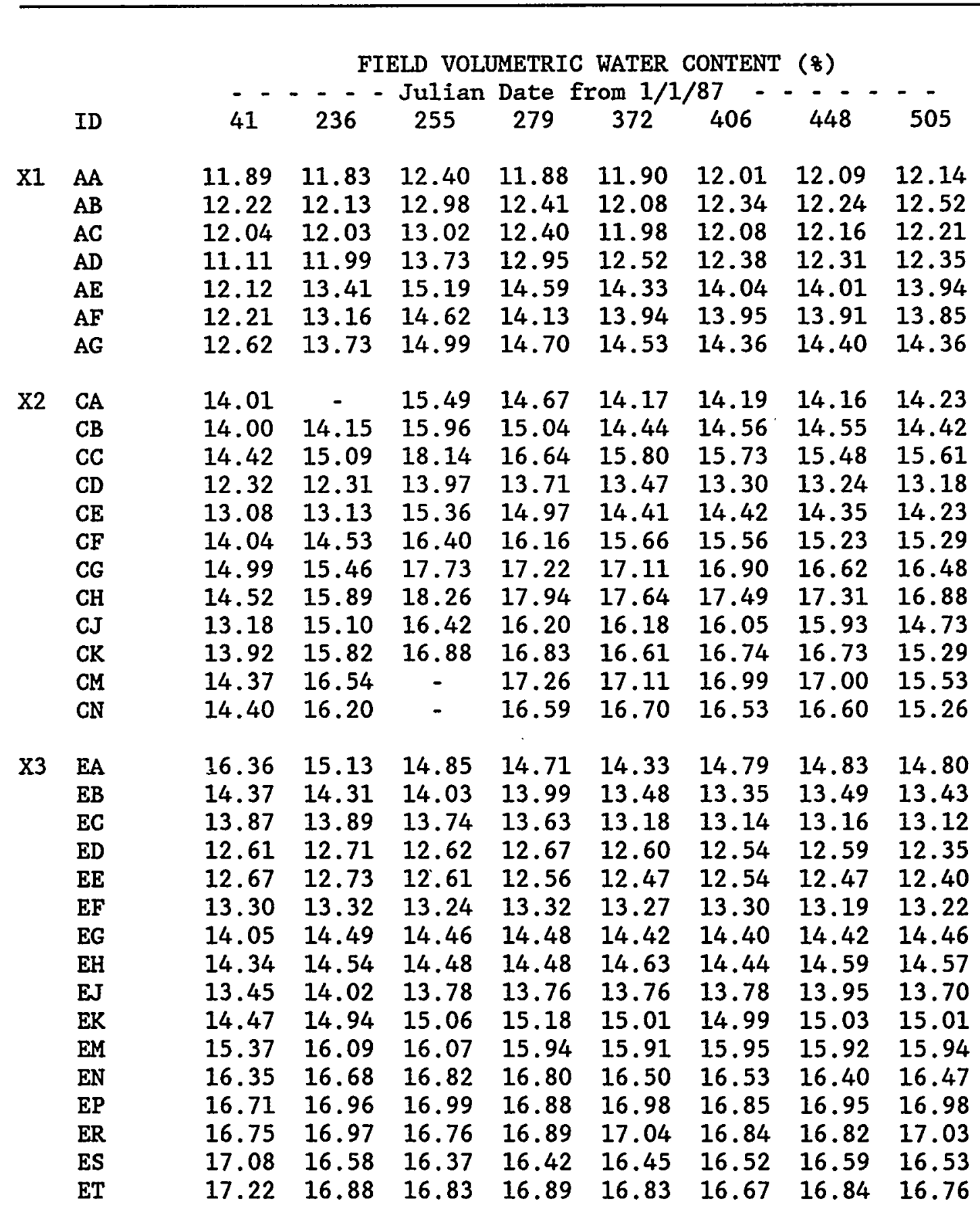


Table A13 (Continued)

FIELD VOLUMETRIC WATER CONTENT $(8)$

ID

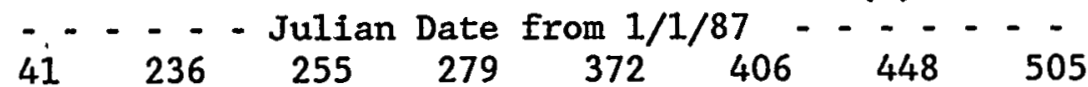

Y1 GB

$\begin{array}{lll}12.25 & 12.11 & 12.80\end{array}$

12.45

$\begin{array}{ll}12.45 & 12.50\end{array}$

$12.60 \quad 12.93$

GC

12.23

12.30

13.26

$12.90 \quad 12.63$

12.66

$12.72 \quad 12.98$

GD

11.70

$\begin{array}{ll}11.91 & 13.03\end{array}$

$12.37,11.93$

12.02

$12.10 \quad 12.44$

10.45

11.44

13.24

$12.55,11.87$

$11.51 \cdot 11.6211 .65$

GF

11.55

12.13

14.22

13.54

13.15

12.96

12.79

12.63

GG

12.01

12.93

14.21

13.70

$13.51,13.42$

$13.37 \quad 13.45$

Y2 JB

$15.46 \quad 16.05$

16.50

16.40

16.1

JC

13.84

14.39

16.43

15.76

15.35

16.32

14.4214 .41

JE

JF

$12.55 \quad 12.28$

15.85

15.38

15.38

15.66

$16.13 \quad 16.06$

$13.04 \quad 12.76$

13.41

13.28

13.13

15.22

15.63

15.55

14.44. 14.15

17.23

14.98

14.44

13.04

$15.47 \quad 15.63$

JH

13.60

13.91

17.17

16.71

15.63

14.49

$13.02 \quad 13.01$

14.55

15.69

18.75

16.55

16.31

13.16

14.45

16.44

18.42

17.74

15.41

$14.18 \quad 14.26$

14.12

15.57

17.55

16.46

16.23

16.00

$15.22 \quad 15.02$

14.12

15.79

17.47

17.29

17.36

17.77

$15.94 \quad 15.73$

$14.50 \quad 16.92$

17.32

17.31

16.08

$17.57 \quad 17.51$

16.10 .16 .15

JP

14.16

$$
13.76
$$

13.68

$13.85 \quad 13.46$

13.26

13.61

13.63

13.65

$-$

17.22

16.81

$17.06 \quad 16.98$

$17.15 \quad 17.20$

$17.16 \quad 17.06$

ME

12.80

12.81

12.73

13.65

13.84

17.16

13.41

13.24

13.74

13.66

13.69

13.58

13.25

13.24

12.71

13.45

13.25

13.20

13.34

14.75

14.63

14.55

13.15

12.68

13.22

$13.40 \quad 13.47$

MG

15.68

15.56

15.77

14.65

13.36

12.48

12.56

12.70

13.66

13.72

13.65

15.47

14.71

13.43

$-$

13.34

MJ

12.88

13.08

13.12

13.74

15.59

14.65

$14.56 \quad 14.67$

13.55

13.92

13.90

13.07

13.80

15.38

$15.58 \quad 15.56$

13.77

14.51

14.33

13.92

12.92

13.72

$13.71 \quad 13.65$

14.90

16.13

15.94

14.48

13.95

13.13

$13.06 \quad 12.75$

14.53

15.61

15.42

15.84

14.34

13.83

13.85

14.17

13.89

15.52

15.58

15.36

$15.38 \quad 15.33$

15.48

16.37

16.17

16.30

15.16

15.10

$15.38 \quad 15.33$

15.38

15.62

15.74

16.36

16.22

$14.98 \quad 15.00$

16.32

15.97

15.89

15.98

15.84

15.65

$\begin{array}{ll}16.29 & 16.21 \\ 15.56 & 15.60\end{array}$

$15.96 \quad 15.93$ 
Table A13 (Continued)

FIELD VOLUMETRIC WATER CONTENT ( $\%$ )

ID

$\mathrm{Z} 1 \mathrm{~PB}$

PC

PD

$\mathrm{PE}$

$\mathrm{PF}$

PG

$\mathrm{PH}$

Z2 SB

SC

SD

SE

SF

SG

$\mathrm{SH}$

SJ

SK

SM

SN

SP

23 UW

UC

UD

UE

UF

UG

$\mathrm{UH}$

UJ

UK

UM

UN

UP

UR

US

UT

UU

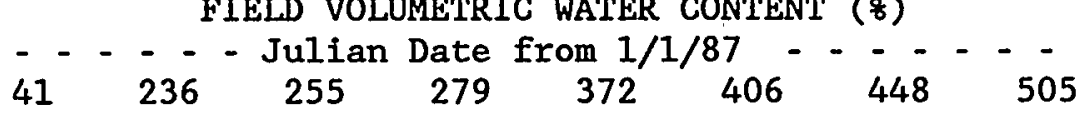

$\begin{array}{cccccccc}17.63 & 16.88 & 16.80 & 17.02 & 16.99 & 17.23 & 17.11 & 16.98 \\ 17.15 & 16.60 & 16.62 & 16.76 & 16.66 & 17.01 & 16.56 & 16.75 \\ 16.03 & 15.47 & 15.55 & 15.55 & 15.71 & 15.79 & 15.79 & 15.67 \\ 14.22 & 13.91 & 13.77 & 13.93 & 14.14 & 14.35 & 13.97 & 14.16 \\ 12.51 & 12.65 & 12.37 & 12.30 & 12.42 & 12.38 & 12.33 & 12.36 \\ 13.52 & 14.28 & 14.01 & 14.03 & 13.78 & 13.66 & 13.60 & 13.59 \\ 12.83 & 12.94 & 13.09 & - & 13.14 & 13.20 & 13.05 & 13.10\end{array}$

$\begin{array}{llllllll}12.80 & 12.63 & 12.73 & 12.77 & 13.00 & 13.23 & 12.96 & 13.01\end{array}$

$\begin{array}{llllllll}12.25 & 12.60 & 12.47 & 12.62 & 12.66 & 12.80 & 12.95 & 12.91\end{array}$

$\begin{array}{llllllll}11.95 & 12.34 & 12.12 & 12.41 & 12.37 & 12.28 & 12.53 & 12.89\end{array}$

$\begin{array}{llllllll}13.33 & 13.15 & 13.15 & 13.34 & 13.28 & 13.35 & 13.27 & 13.58\end{array}$

$\begin{array}{llllllll}14.73 & 14.81 & 14.67 & 14.61 & 14.56 & 14.44 & 14.49 & 14.48\end{array}$

$\begin{array}{llllllll}17.35 & 17.29 & 17.37 & 17.25 & 17.07 & 17.23 & 17.15 & 16.86\end{array}$

$\begin{array}{llllllll}13.93 & 14.05 & 14.15 & 13.85 & 13.97 & 13.75 & 13.81 & 13.75\end{array}$

$\begin{array}{lllllllll}13.55 & 13.67 & 13.87 & 13.70 & 13.71 & 13.62 & 13.76 & 13.68\end{array}$

$\begin{array}{llllllll}12.90 & 12.97 & 12.98 & 12.85 & 12.88 & 12.91 & 12.90 & 12.93\end{array}$

$\begin{array}{llllllll}12.17 & 12.66 & 12.69 & 12.66 & 12.64 & 12.58 & 12.52 & 12.53\end{array}$

$\begin{array}{llllllll}12.55 & 14.04 & 13.78 & 13.83 & 13.86 & 13.73 & 13.87 & 13.69\end{array}$

$\begin{array}{llllllll}13.49 & 15.40 & 15.43 & 15.28 & 15.24 & 15.06 & 15.05 & 15.11\end{array}$

$\begin{array}{rrrrrrrr}12.17 & 11.66 & 11.60 & 11.49 & 12.45 & 12.42 & 12.35 & 12.44 \\ 11.18 & 10.85 & 11.05 & 10.78 & 10.14 & 10.69 & 10.79 & 10.93 \\ 10.91 & 11.01 & 10.91 & 11.13 & 9.99 & 10.18 & 10.51 & 10.54 \\ 10.19 & 10.94 & 10.89 & 10.77 & 10.06 & 9.53 & 9.85 & 10.14 \\ 11.98 & 11.41 & 11.28 & 11.29 & 11.38 & 11.28 & 11.33 & 11.18 \\ 12.74 & 12.86 & 12.86 & 12.90 & 12.72 & 12.68 & 12.79 & 12.60 \\ 14.04 & 14.22 & 14.19 & 14.06 & 14.04 & 14.04 & 14.01 & 13.94 \\ 13.35 & 13.56 & 13.56 & 13.65 & 13.66 & 13.54 & 13.65 & 13.65 \\ 12.58 & 12.33 & 12.49 & 12.45 & 12.39 & 12.41 & 12.45 & 12.30 \\ 13.54 & 13.73 & 13.68 & 13.85 & 13.68 & 13.64 & 13.68 & 13.72 \\ 14.19 & 14.89 & 14.89 & 14.89 & 14.74 & 14.77 & 14.89 & 14.65 \\ 14.13 & 14.97 & 14.94 & 14.99 & 14.90 & 14.90 & 14.85 & 14.92 \\ 14.36 & 15.09 & 14.90 & 14.90 & 14.97 & 14.86 & 14.79 & 14.82 \\ 14.48 & 15.16 & 15.19 & 15.23 & 14.95 & 15.07 & 15.00 & 15.04 \\ 14.88 & 14.91 & 14.94 & 14.84 & 14.84 & 14.66 & 14.69 & 14.64 \\ 14.03 & 14.80 & 14.56 & 14.70 & 14.50 & 14.45 & 14.40 & 14.39\end{array}$


Table A14: Laboratory unsaturated air permeability $\left(\mathrm{m}^{2} \times \mathrm{E}-16\right)$.

\begin{tabular}{|c|c|c|c|c|c|c|c|c|}
\hline & ID & kair & 10 & $\begin{array}{l}\text { LABORATORY } \\
\begin{array}{c}-- \\
25\end{array}\end{array}$ & $\begin{array}{l}\text { AIR-PERME } \\
-\quad \text { Suction } \\
50\end{array}$ & $\begin{array}{l}\text { ABILITY } \\
(\mathrm{kPa}) \\
100\end{array}$ & $\begin{array}{c}\left(\mathrm{m}^{2} \times \mathrm{E}-16\right) \\
-300 \\
30\end{array}$ & -- \\
\hline 1 & $\begin{array}{l}A A \\
A B \\
A C \\
A D \\
A E \\
A F \\
A G\end{array}$ & $\begin{array}{r}84.27 \\
15.06 \\
13.62 \\
5.35 \\
4.40 \\
4.17 \\
3.98\end{array}$ & $\begin{array}{r}10.53 \\
0.02 \\
0.04 \\
<0.01 \\
0.10 \\
0.03 \\
0.23\end{array}$ & $\begin{array}{c}37.55 \\
0.21 \\
0.06 \\
0.02 \\
0.03 \\
0.07 \\
0.08\end{array}$ & $\begin{array}{r}35.34 \\
2.79 \\
0.61 \\
0.32 \\
0.18 \\
0.22 \\
0.05\end{array}$ & $\begin{array}{l}.40 .65 \\
5.31 \\
2.31 \\
0.91 \\
0.78 \\
1.08 \\
0.89\end{array}$ & $\begin{array}{r}45.57 \\
9.28 \\
4.73 \\
2.17 \\
1.99 \\
2.38 \\
1.89\end{array}$ & $\begin{array}{r}49.57 \\
9.74 \\
5.22 \\
2.34 \\
\times 2.64 \\
2.79 \\
2.31\end{array}$ \\
\hline 2 & $\begin{array}{l}C A \\
C B \\
C C \\
C D \\
C E \\
C F \\
C G \\
C H \\
C J \\
C K \\
C M \\
C N\end{array}$ & $\begin{array}{r}254.79 \\
17.08 \\
13.52 \\
8.19 \\
6.03 \\
24.99 \\
20.37 \\
66.29 \\
9.94 \\
13.51 \\
15.16 \\
6.51\end{array}$ & $\begin{array}{r}0.10 \\
0.05 \\
0.03 \\
0.02 \\
<0.01 \\
0.02 \\
0.11 \\
0.36 \\
0.02 \\
<0.01 \\
0.05 \\
0.08\end{array}$ & $\begin{array}{l}2.62 \\
0.05 \\
0.04 \\
0.05 \\
0.66 \\
0.48 \\
0.70 \\
1.52 \\
0.03 \\
0.02 \\
0.07 \\
0.12\end{array}$ & $\begin{array}{r}88.32 \\
0.05 \\
0.61 \\
0.03 \\
2.16 \\
0.44 \\
2.95 \\
10.94 \\
0.13 \\
0.06 \\
1.41 \\
0.15\end{array}$ & $\begin{array}{r}144.67 \\
0.80 \\
3.32 \\
0.44 \\
2.36 \\
6.45 \\
10.10 \\
34.81 \\
0.87 \\
2.91 \\
6.19 \\
0.37\end{array}$ & $\begin{array}{r}179.03 \\
2.59 \\
3.83 \\
1.62 \\
3.87 \\
17.47 \\
14.87 \\
46.51 \\
6.53 \\
7.08 \\
12.18 \\
3.05\end{array}$ & $\begin{array}{r}190.96 \\
4.03 \\
6.55 \\
1.99 \\
4.44 \\
18.93 \\
16.27 \\
48.04 \\
7.00 \\
8.20 \\
12.41 \\
3.94\end{array}$ \\
\hline & $\begin{array}{l}E A \\
E B \\
E C \\
E D \\
E E \\
E F \\
E G \\
\text { EH } \\
\text { EJ } \\
\text { EK } \\
\text { EM } \\
\text { EN } \\
\text { EP } \\
\text { ER } \\
\text { ES } \\
\text { ET }\end{array}$ & $\begin{array}{l}30.72 \\
12.73 \\
27.62 \\
16.26 \\
21.67 \\
14.79 \\
9.92 \\
9.51 \\
6.30 \\
6.00 \\
5.27 \\
6.01 \\
9.04 \\
7.20 \\
8.50 \\
5.20\end{array}$ & $\begin{array}{l}0.85 \\
0.03 \\
0.06 \\
0.02 \\
0.05 \\
0.10 \\
0.02 \\
0.03 \\
0.03 \\
0.14 \\
0.02 \\
0.04 \\
0.03 \\
0.04 \\
0.08 \\
0.02\end{array}$ & $\begin{array}{l}3.35 \\
0.23 \\
0.12 \\
0.06 \\
0.37 \\
0.08 \\
0.02 \\
0.04 \\
0.02 \\
0.06 \\
0.02 \\
0.04 \\
0.04 \\
0.04 . \\
0.10 \\
0.03 .\end{array}$ & $\begin{array}{l}3.92 \\
1.14 \\
0.42 \\
0.14 \\
0.46 \\
0.15 \\
0.03 \\
0.10 \\
0.08 \\
0.09 \\
0.02 \\
0.08 \\
0.19 \\
0.06 \\
0.07 \\
0.04\end{array}$ & $\begin{array}{r}8.66 \\
4.69 \\
4.41 \\
2.19 \\
5.63 \\
2.11 \\
2.96 \\
3.08 \\
0.82 \\
0.62 \\
0.63 \\
0.59 \\
0.71 \\
0.91 \\
0.25 \\
0.47\end{array}$ & $\begin{array}{r}11.54 \\
8.10 \\
5.94 \\
2.62 \\
6.69 \\
5.13 \\
6.20 \\
5.62 \\
2.47 \\
2.99 \\
1.97 \\
3.59 \\
6.31 \\
4.21 \\
4.70 \\
2.68\end{array}$ & $\begin{array}{r}13.69 \\
9.38 \\
6.07 \\
2.78 \\
5.58 \\
4.88 \\
6.87 \\
6.44 \\
3.34 \\
3.73 \\
2.77 \\
4.26 \\
6.67 \\
4.85 \\
6.09 \\
3.48\end{array}$ \\
\hline
\end{tabular}


Table A14 (Continued)

LABORATORY AIR-PERMEABILITY ( $\mathrm{m}^{2} \mathrm{x}$ E-16)

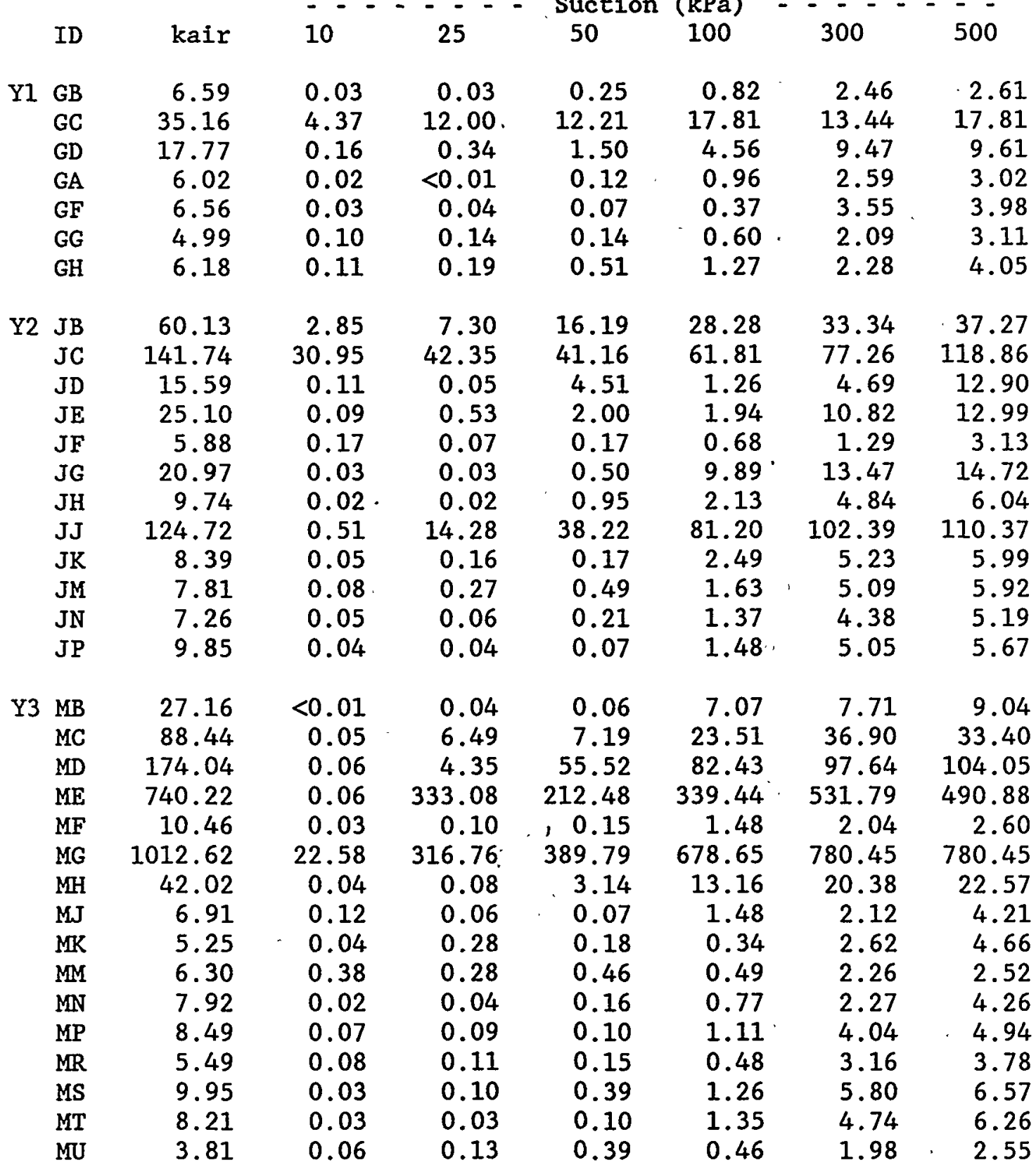


Table A14 (Gontinued)

LABORATORY AIR-PERMEABILITY ( $\left.\mathrm{m}^{2} \times \mathrm{E}-16\right)$

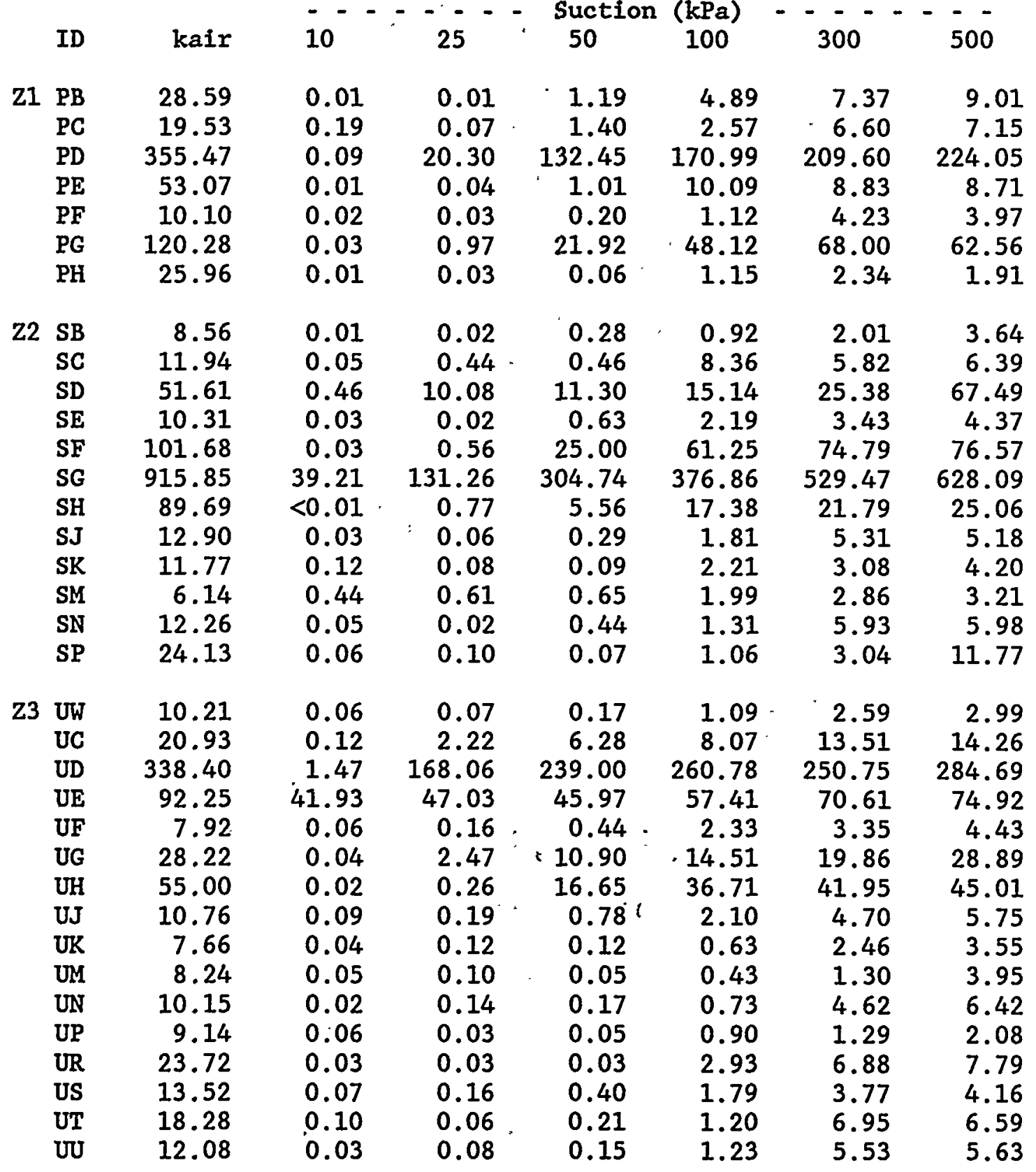


Table A15: Klinkenberg coefficients obtained from laboratory air/water permeability ratios for 105 large core segments.

\begin{tabular}{|c|c|c|c|c|c|c|c|c|}
\hline ID & & $\begin{array}{l}\text { Klinkenberg } \\
\text { Coef. (kPa) }\end{array}$ & ID & & $\begin{array}{l}\text { Klinkenberg } \\
\text { Coef. }(\mathrm{kPa})\end{array}$ & ID & & $\begin{array}{l}\text { Klinkenber } \\
\text { Coef. }(\mathrm{kPa}\end{array}$ \\
\hline $\mathrm{X} 1$ & $\begin{array}{l}\mathrm{AA} \\
\mathrm{AB} \\
\mathrm{AC} \\
\mathrm{AD} \\
\mathrm{AE} \\
\mathrm{AF} \\
\mathrm{AG}\end{array}$ & $\begin{array}{l}575 . \\
264 . \\
613 . \\
408 . \\
401 . \\
242 . \\
206 .\end{array}$ & $\mathrm{Y} 1$ & $\begin{array}{l}\text { GB } \\
\text { GC } \\
\text { GD } \\
\text { GA } \\
\text { GF } \\
\text { GG } \\
\text { GH }\end{array}$ & $\begin{array}{l}335 . \\
777 . \\
468 . \\
521 . \\
637 . \\
294 . \\
190 .\end{array}$ & $\mathrm{Z1}$ & $\begin{array}{l}P B \\
P C \\
P D \\
P E \\
P F \\
P G \\
P H\end{array}$ & $\begin{array}{r}497 . \\
541 . \\
290 \\
1260 \\
382 \\
434 . \\
1047\end{array}$ \\
\hline $\mathrm{x} 2$ & $\begin{array}{l}\mathrm{CA} \\
\mathrm{CB} \\
\mathrm{CC} \\
\mathrm{CD} \\
\mathrm{CE} \\
\mathrm{CF} \\
\mathrm{CG} \\
\mathrm{CH} \\
\mathrm{CJ} \\
\mathrm{CK} \\
\mathrm{CM} \\
\mathrm{CN}\end{array}$ & $\begin{array}{r}95 . \\
481 . \\
243 . \\
1277 . \\
176 . \\
76 . \\
104 . \\
97 . \\
130 . \\
129 . \\
108 . \\
168 .\end{array}$ & $\mathrm{Y} 2$ & $\begin{array}{l}\mathrm{JB} \\
\mathrm{JC} \\
\mathrm{JD} \\
\mathrm{JE} \\
\mathrm{JF} \\
\mathrm{JG} \\
\mathrm{JH} \\
\mathrm{JJ} \\
\mathrm{JK} \\
\mathrm{JM} \\
\mathrm{JN} \\
\mathrm{JP}\end{array}$ & $\begin{array}{c}325 . \\
808 \\
708 \\
904 . \\
234 . \\
114 . \\
204 . \\
67 . \\
123 . \\
105 . \\
130 \\
137 .\end{array}$ & $\mathrm{z2}$ & $\begin{array}{l}\text { SB } \\
\text { SC } \\
\text { SD } \\
\text { SE } \\
\text { SF } \\
\text { SG } \\
\text { SH } \\
\text { SJ } \\
\text { SK } \\
\text { SM } \\
\text { SN } \\
\text { SP }\end{array}$ & $\begin{array}{l}584 . \\
356 . \\
255 . \\
142 . \\
108 . \\
174 . \\
967 . \\
242 . \\
282 . \\
232 . \\
210 . \\
236 .\end{array}$ \\
\hline $\mathrm{X} 3$ & $\begin{array}{l}\text { EA } \\
\text { EB } \\
\text { EC } \\
\text { ED } \\
\text { EE } \\
\text { EF } \\
\text { EG } \\
\text { EH } \\
\text { EJ } \\
\text { EK } \\
\text { EM } \\
\text { EN } \\
\text { EP } \\
\text { ER } \\
\text { ES } \\
\text { ET }\end{array}$ & $\begin{array}{r}409 . \\
213 . \\
765 . \\
577 . \\
831 . \\
445 . \\
139 . \\
89 . \\
143 . \\
106 . \\
135 . \\
232 . \\
100 . \\
115 . \\
119 . \\
176 .\end{array}$ & Y3 & $\begin{array}{l}\text { MB } \\
M C \\
M D \\
\text { ME } \\
\text { MF } \\
\text { MG } \\
\text { MH } \\
\text { MJ } \\
\text { MK } \\
\text { MM } \\
\text { MN } \\
\text { MP } \\
\text { MR } \\
\text { MS } \\
\text { MT } \\
\text { MU }\end{array}$ & $\begin{array}{r}439 . \\
865 . \\
538 . \\
250 . \\
757 . \\
160 . \\
257 . \\
109 . \\
35 . \\
170 . \\
109 . \\
162 . \\
202 . \\
185 . \\
130 . \\
199 .\end{array}$ & Z3 & $\begin{array}{l}\text { UW } \\
\text { UC } \\
\text { UD } \\
\text { UE } \\
\text { UF } \\
\text { UG } \\
\text { UH } \\
\text { UJ } \\
\text { UK } \\
\text { UM } \\
\text { UN } \\
\text { UP } \\
\text { UR } \\
\text { US } \\
\text { UT } \\
\text { UU }\end{array}$ & $\begin{array}{r}774 . \\
262 . \\
99 . \\
98 . \\
281 . \\
101 . \\
213 . \\
199 . \\
161 . \\
90 . \\
136 . \\
177 . \\
335 . \\
168 . \\
237 . \\
217 .\end{array}$ \\
\hline
\end{tabular}


Table Al6: Field observed flow rates and interpreted air permeability.

ID Date

Injection.

Flow Rate

Pressure, $\mathrm{kPa} \mathrm{m} 3 / \mathrm{s} \times \mathrm{E}-9$

Permeablity
m2 x E-16

$\mathrm{XI} \quad \mathrm{AA}$

$A B$

$A C$

$-$

91.2

91.4

$\mathrm{AD}$

$07 / 21 / 88$

91.6

91.5

$\mathrm{AE}$

$08 / 04 / 88$

91.2

$07 / 21 / 88$

$08 / 04 / 88$

AF $\quad 08 / 04 / 88$

91.2

150.6

$09 / 01 / 88$

AG $\quad 09 / 08 / 88$

91.2

90.9

$09 / 08 / 88$

91.1

$09 / 13 / 88$.

90.9

$\mathrm{x} 2$

$\begin{array}{lc}C A & - \\ C B & - \\ C C & 08 / 04 / 88\end{array}$

$09 / 01 / 88$

CD $\quad 07 / 13 / 88$

$09 / 01 / 88$

CE $\quad 07 / 14 / 88$

$08 / 04 / 88$

CF $\quad 07 / 14 / 88$

$08 / 04 / 88$

CG $\quad 07 / 13 / 88$

$08 / 15 / 88$

$\mathrm{CH} \quad 07 / 13 / 88$

$08 / 15 / 88$

CJ $\quad 07 / 13 / 88$

$07 / 13 / 88$

$08 / 15 / 88$

CK $\quad 08 / 15 / 88$

$08 / 25 / 88$

$09 / 01 / 88$

CM $\quad 07 / 13 / 88$

$08 / 15 / 88$

CN $\quad 09 / 06 / 88$

$09 / 08 / 88$

91.2

91.0

91.3

91.1

91.1

91.3

87.2

87.1

91.0

91.6

91.5

91.4

91.0

90.9

91.0

91.1

148.3

91.1

91.2

91.2

91.5

91.5

-
-
602.35
516.62
219.40
307.10
7615.4
7677.3
1766.9
124.64
78.40
117.59
77.27

5.20

4.30

1.78

2.54

66.05

66.46

0.93

1.08

0.48

0.70

0.48

24.49

2806.9

2881.8

77.83

105.47

1854.9

1799.5

15837.

16274.

1463.7

1737.6

1044.5

1349.6

2242.9

2184.2

2324.4

227.57

2448.3

166.38

200.50

26.26

0.66

0.95

16.63

15.23

624.23

699.98

13.38

13.96

8.62

11.21

20.52

20.21

21.16

2.04

1.35

1.46

1.75

2.24

258.03

1.07

127.75

0.91 
Table A16 (Continued)

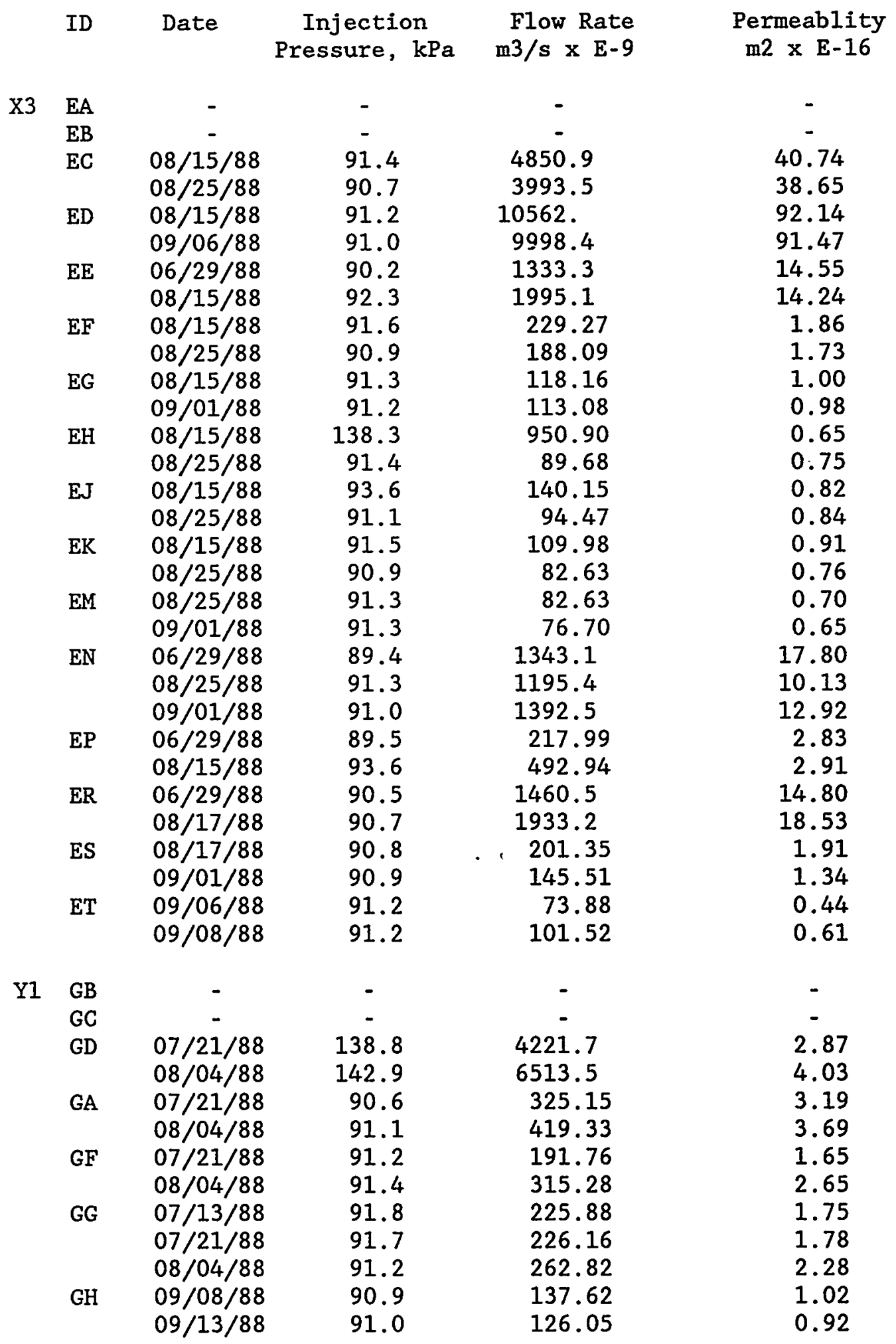




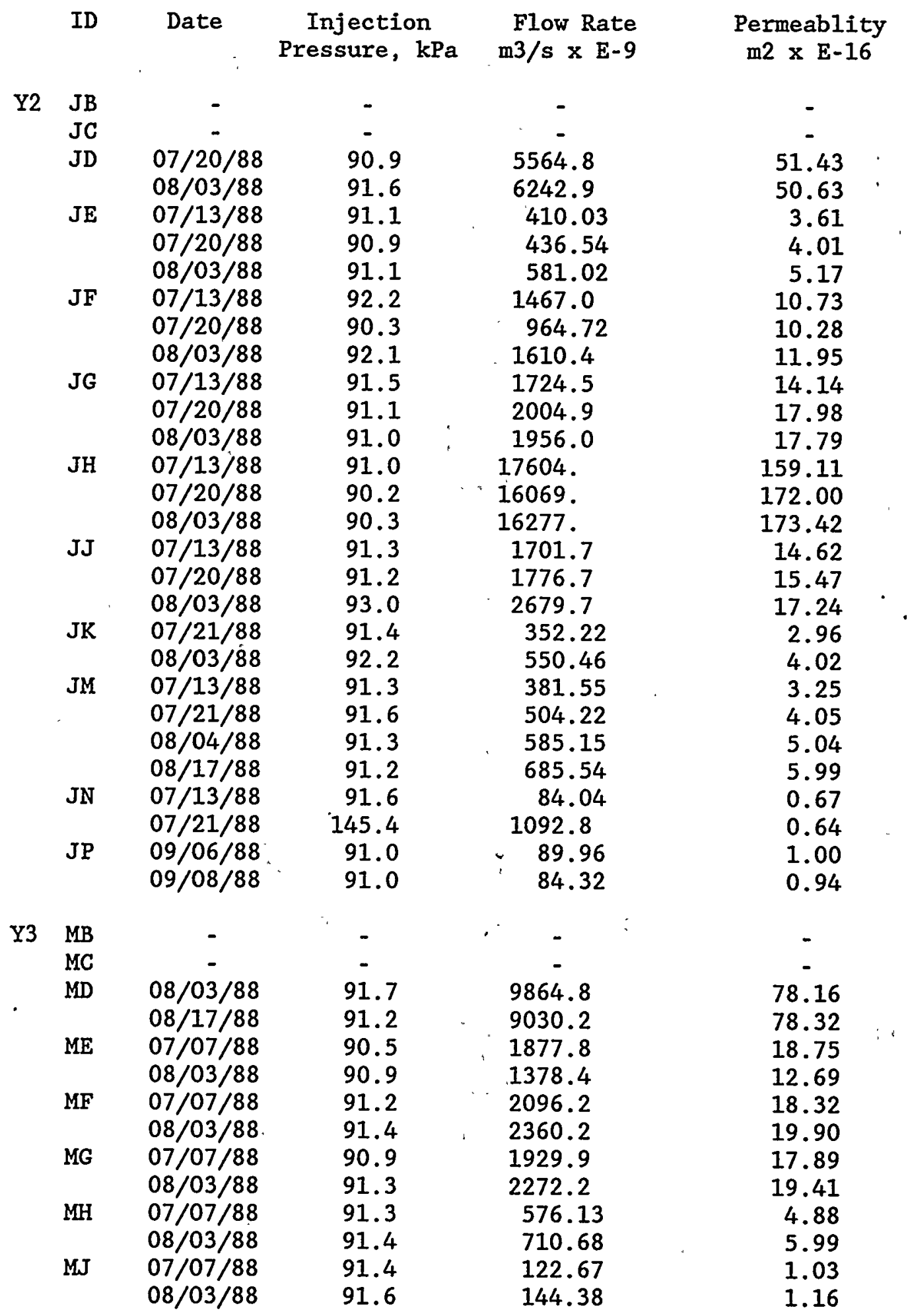


Table A16 (Continued)

\begin{tabular}{|c|c|c|c|c|}
\hline ID & Date & $\begin{array}{c}\text { Injection } \\
\text { Pressure, } \mathrm{kPa}\end{array}$ & $\begin{array}{l}\text { Flow Rate } \\
\mathrm{m} 3 / \mathrm{s} \times \mathrm{E}-9\end{array}$ & $\begin{array}{l}\text { Permeablity } \\
\text { m2 x E-16 }\end{array}$ \\
\hline MK & $\begin{array}{l}08 / 03 / 88 \\
08 / 17 / 88\end{array}$ & $\begin{array}{l}91.5 \\
90.9\end{array}$ & $\begin{array}{l}190.63 \\
236.88\end{array}$ & $\begin{array}{l}1.58 \\
2.17\end{array}$ \\
\hline $\mathbf{M M}$ & $\begin{array}{l}08 / 03 / 88 \\
08 / 17 / 88 \\
08 / 25 / 88\end{array}$ & $\begin{array}{l}91.5 \\
91.7 \\
91.3\end{array}$ & $\begin{array}{l}408.34 \\
263.39 \\
328.25\end{array}$ & $\begin{array}{l}3.37 \\
2.11 \\
2.79\end{array}$ \\
\hline $\mathbf{M N}$ & $\begin{array}{l}08 / 03 / 88 \\
08 / 17 / 88\end{array}$ & $\begin{array}{l}91.4 \\
91.7\end{array}$ & $\begin{array}{l}170.89 \\
159.61\end{array}$ & $\begin{array}{l}1.43 \\
1.28\end{array}$ \\
\hline$M P$ & $\begin{array}{l}08 / 03 / 88 \\
08 / 17 / 88\end{array}$ & $\begin{array}{l}91.0 \\
90.9\end{array}$ & $\begin{array}{l}328.25 \\
329.09\end{array}$ & $\begin{array}{l}2.98 \\
3.04\end{array}$ \\
\hline $\mathbf{M R}$ & $\begin{array}{l}08 / 03 / 88 \\
08 / 25 / 88\end{array}$ & $\begin{array}{l}91.4 \\
90.9\end{array}$ & $\begin{array}{l}195.71 \\
139.59\end{array}$ & $\begin{array}{l}1.64 \\
1.29\end{array}$ \\
\hline MS & $\begin{array}{l}08 / 03 / 88 \\
08 / 25 / 88 \\
09 / 01 / 88\end{array}$ & $\begin{array}{l}91.1 \\
91.0 \\
91.2\end{array}$ & $\begin{array}{r}154.25 \\
87.98 \\
118.44\end{array}$ & $\begin{array}{l}1.38 \\
0.79 \\
1.04\end{array}$ \\
\hline MT & $\begin{array}{l}08 / 25 / 88 \\
09 / 01 / 88\end{array}$ & $\begin{array}{l}91.1 \\
90.9\end{array}$ & $\begin{array}{l}77.27 \\
80.65\end{array}$ & $\begin{array}{l}0.68 \\
0.74\end{array}$ \\
\hline MU & $\begin{array}{l}09 / 06 / 88 \\
09 / 08 / 88\end{array}$ & $\begin{array}{l}91.2 \\
91.2\end{array}$ & $\begin{array}{l}73.88 \\
61.76\end{array}$ & $\begin{array}{l}0.50 \\
0.42\end{array}$ \\
\hline PB & - & - & - & - \\
\hline$P C$ & - & - & - & - \\
\hline PD & $\begin{array}{l}07 / 18 / 88 \\
08 / 17 / 88\end{array}$ & $\begin{array}{l}90.1 \\
90.0\end{array}$ & $\begin{array}{l}15834 . \\
13689\end{array}$ & $\begin{array}{l}173.99 \\
156.84\end{array}$ \\
\hline $\mathrm{PE}$ & $\begin{array}{l}07 / 18 / 88 \\
08 / 17 / 88\end{array}$ & $\begin{array}{l}89.8 \\
90.1\end{array}$ & $\begin{array}{l}15022 \\
15899\end{array}$ & $\begin{array}{l}179.32 \\
178.14\end{array}$ \\
\hline $\mathrm{PF}$ & $\begin{array}{l}08 / 17 / 88 \\
09 / 01 / 88\end{array}$ & $\begin{array}{l}86.1 \\
86.1\end{array}$ & $\begin{array}{l}16307 \\
16267\end{array}$ & $\begin{array}{l}7532.4 \\
5822.5\end{array}$ \\
\hline$P G$ & $\begin{array}{l}07 / 18 / 88 \\
08 / 17 / 88\end{array}$ & $\begin{array}{l}90.7 \\
90.9\end{array}$ & $\begin{array}{l}11853 . \\
13663\end{array}$ & $\begin{array}{l}113.49 \\
126.01\end{array}$ \\
\hline
\end{tabular}

PH (Permeability exceeds, measurement capability)

$\mathrm{Z2} \mathrm{SB}$

$S C$

SD

SE - $08 / 17 / 88$

$08 / 17 / 88$

$09 / 01 / 88$

90.8

91.3

$09 / 01 / 88$

SF

$07 / 20 / 88$

$08 / 17 / 88$

SG

$07 / 20 / 88$

$08 / 17 / 88$

SH $\quad 07 / 20 / 88$

$08 / 17 / 88$

SJ $\quad 07 / 20 / 88$

$08 / 17 / 88$

91.3

91.1

90.6

91.1

88.9

89.2

90.6

91.4

87.9

88.1

-
-
54.14
50.20
92.78
97.85
8736.8
9916.9
16238.
16297.
1871.2
2402.6
16277.
16297.

0.52

0.43

0.79

0.87

86.58

87.53

255.58

235.60

18.50

20.25

395.61

358.72 
Table A16 (Continued)

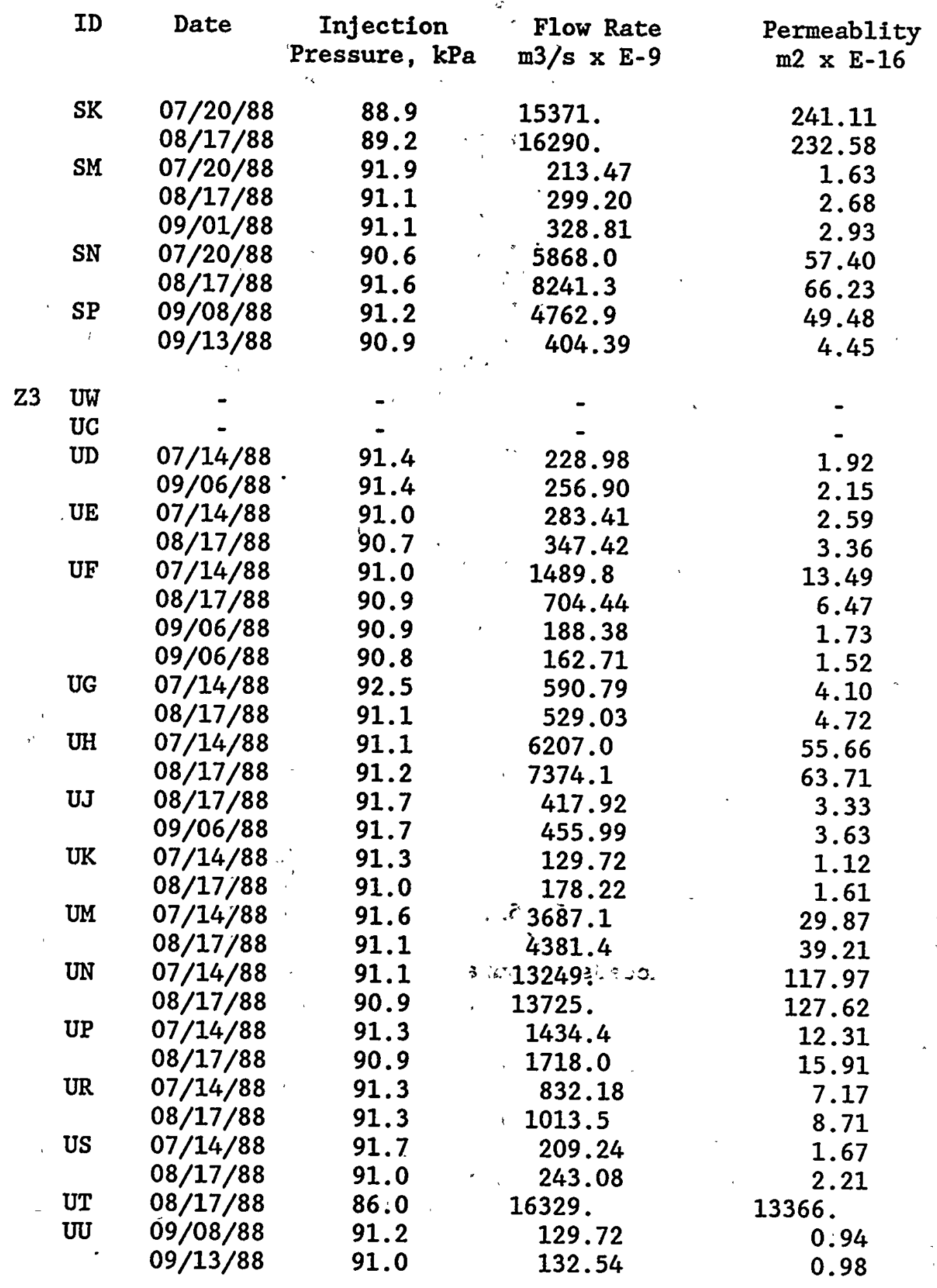


Table A17: Laboratory-estimated thermal conductivity $\left(\mathrm{J} / \mathrm{m} / \mathrm{s} /{ }^{\circ} \mathrm{K}\right)$ and dry rock specific heat $\left(\mathrm{J} / \mathrm{kg} /{ }^{\circ} \mathrm{K}\right)$ for saturated, variably saturated and oven-dried large core segments.

\begin{tabular}{|c|c|c|c|c|c|c|c|c|c|c|}
\hline \multirow{3}{*}{ ID } & & \multicolumn{8}{|c|}{ THERMAL CONDUCTIVITY $\left(\mathrm{J} / \mathrm{m} / \mathrm{s} /{ }^{\circ} \mathrm{K}\right)$} & \multirow{3}{*}{$\begin{array}{c}\text { Dry Rock } \\
\text { Specific Heat } \\
\left(\mathrm{J} / \mathrm{kg} /{ }^{\circ} \mathrm{K}\right)\end{array}$} \\
\hline & & -- & -- & & ction & & & . & . & \\
\hline & & 0 & 10 & 25 & 50 & 100 & 300 & 500 & dry & \\
\hline$X I$ & AA & 1.875 & 1.780 & 1.913 & 1.691 & 1.670 & 1.568 & 1.683 & 1.197 & 595.09 \\
\hline & $A B$ & 1.621 & 1.986 & 1.767 & 1.956 & 2.242 & 1.650 & 1.982 & 1.487 & 822.37 \\
\hline & $\mathrm{AC}$ & 1.989 & 1.565 & 1.640 & 1.603 & 1.835 & 2.066 & 1.796 & 1.388 & 692.02 \\
\hline & $\mathrm{AD}$ & 2.135 & 1.666 & 1.733 & 1.664 & 1.938 & 1.863 & 1.797 & $1: 491$ & 604.79 \\
\hline & $\mathrm{AE}$ & 1.938 & 1.736 & 1.936 & 1.908 & 2.239 & 1.876 & 1.775 & 1.596 & 795.11 \\
\hline & $\mathrm{AF}$ & 2.075 & 2.005 & 2.089 & 2.063 & 2.313 & 1.837 & 1.958 & 1.347 & 680.09 \\
\hline & AG & 1.994 & 1.651 & 1.727 & 1.685 & 1.964 & 1.885 & 1.890 & 1.469 & 637.67 \\
\hline $\mathrm{X} 2$ & $\mathrm{CA}$ & 1.853 & 1.871 & 1.572 & 1.552 & 1.651 & 1.527 & 1.663 & 1.064 & 1168 \\
\hline & $\mathrm{CB}$ & 1.922 & 2.013 & 1.813 & 1.990 & 1.814 & 1.572 & 2.084 & 1.198 & 1125 \\
\hline & CC & 2.174 & 1.937 & 1.989 & 2.568 & 1.881 & 1.845 & 1.610 & 1.430 & 748.75 \\
\hline & $C D$ & 1.707 & 1.868 & 2.287 & 2.030 & 2.785 & 2.040 & 1.939 & 1.335 & 770.39 \\
\hline & $\mathrm{CE}$ & 1.894 & 1.829 & 1.857 & 1.815 & 1.796 & 1.704 & 1.762 & 1.279 & 498.71 \\
\hline & $\mathrm{CF}$ & 2.017 & 2.107 & 1.947 & 1.925 & 1.871 & 1.632 & 1.841 & 1.319 & 748 \\
\hline & CG & 1.637 & 1.597 & 1.737 & 1.912 & 1.517 & 1.719 & 1.349 & 1.333 & 915.32 \\
\hline & $\mathrm{CH}$ & 2.025 & 2.026 & 1.964 & 1.720 & 1.676 & 1.651 & 1.591 & 1.189 & 837.35 \\
\hline & CJ & 2.019 & 2.204 & 2.114 & 2.038 & 2.037 & 1.847 & 2.030 & 1.200 & 694.59 \\
\hline & CK & 1.898 & 1.839 & 1.647 & 1.907 & 1.857 & 2.575 & 1.634 & 1.268 & 511.14 \\
\hline & CM & 1.660 & 1.678 & 1.840 & 1.797 & 1.694 & 1.797 & 1.752 & 1.401 & 756.31 \\
\hline & $\mathrm{CN}$ & 1.603 & 1.689 & 1.742 & 1.356 & 1.814 & 1.506 & 1.338 & .987 & 468.52 \\
\hline $\mathrm{x} 3$ & EA & 1.839 & 1.883 & 1.855 & 1.734 & 1.785 & $1.685^{\circ}$ & 1.844 & 1.088 & 447.99 \\
\hline & EB & 1.983 & 1.771 & 1.722 & 1.654 & 1.745 & 1.749 & 1.809 & 1.223 & 583.80 \\
\hline & EC & 1.901 & 1.844 & 2.000 & 1.678 & 1.951 & 1.615 & 1.708 & 1.149 & 578.51 \\
\hline & ED & 1.835 & 1.978 & 2.377 & 2.017 & 2.194 & 2.333 & 2.065 & 1.311 & 512.15 \\
\hline & $\mathrm{EE}$ & 1.908 & 1.742 & 1.752 & 1.718 & 1.948 & 1.754 & 1.838 & 1.328 & 626.39 \\
\hline & $\mathrm{EF}$ & 1.912 & 1.904 & 1.827 & 1.944 & 2.036 & 1.515 & 2.127 & 1.343 & 345.18 \\
\hline & EG & 2.237 & 1.886 & 1.968 & 2.136 & 1.972 & 1.910 & 1.822 & 1.443 & 726.25 \\
\hline & $\mathbf{E H}$ & 2.202 & 1.747 & 2.580 & 2.459 & 2.116 & 1.896 & 2.138 & 1.280 & 976.70 \\
\hline & EJ & 1.877 & 1.779 & 1.814 & $1: 811$ & 1.804 & 1.810 & 1.698 & 1.290 & 482.28 \\
\hline & EK & 1.773 & 1.828 & 1.917 & 1.983 & 1.797 & 1.687 & 1.884 & 1.126 & 548.81 \\
\hline & EM & 1.746 & 1.757 & 2.000 & 1.810 & 2.030 & 1.726 & 1.681 & 1.212 & 726.72 \\
\hline & EN & 1.853 & 2.021 & 1.832 & 1.758 & 1.835 & 1.911 & 1.986 & 1.111 & 580.79 \\
\hline & EF & 1.767 & 1.883 & 1.801 & 1.793 & 1.586 & 1.614 & 1.957 & $1: 141$ & 724.15 \\
\hline & ER & 1.615 & 1.570 & 1.695 & 1.591 & 1.540 & 1.560 & 1.688 & 1.343 & 668.97 \\
\hline & ES & 1.757 & 1.518 & 1.590 & 1.586 & 1.686 & 2.080 & 1.631 & 1.232 & 683.57 \\
\hline & ET & 1.825 & 1.920 & 2.216 & 1.924 & 1.806 & 1.530 & 1.848 & 1.966 & 517.48 \\
\hline
\end{tabular}


Table A17 (Gontinued)

THERMAL CONDUCTIVITY $\left(\mathrm{J} / \mathrm{m} / \mathrm{s} /{ }^{\circ} \mathrm{K}\right)$

ID

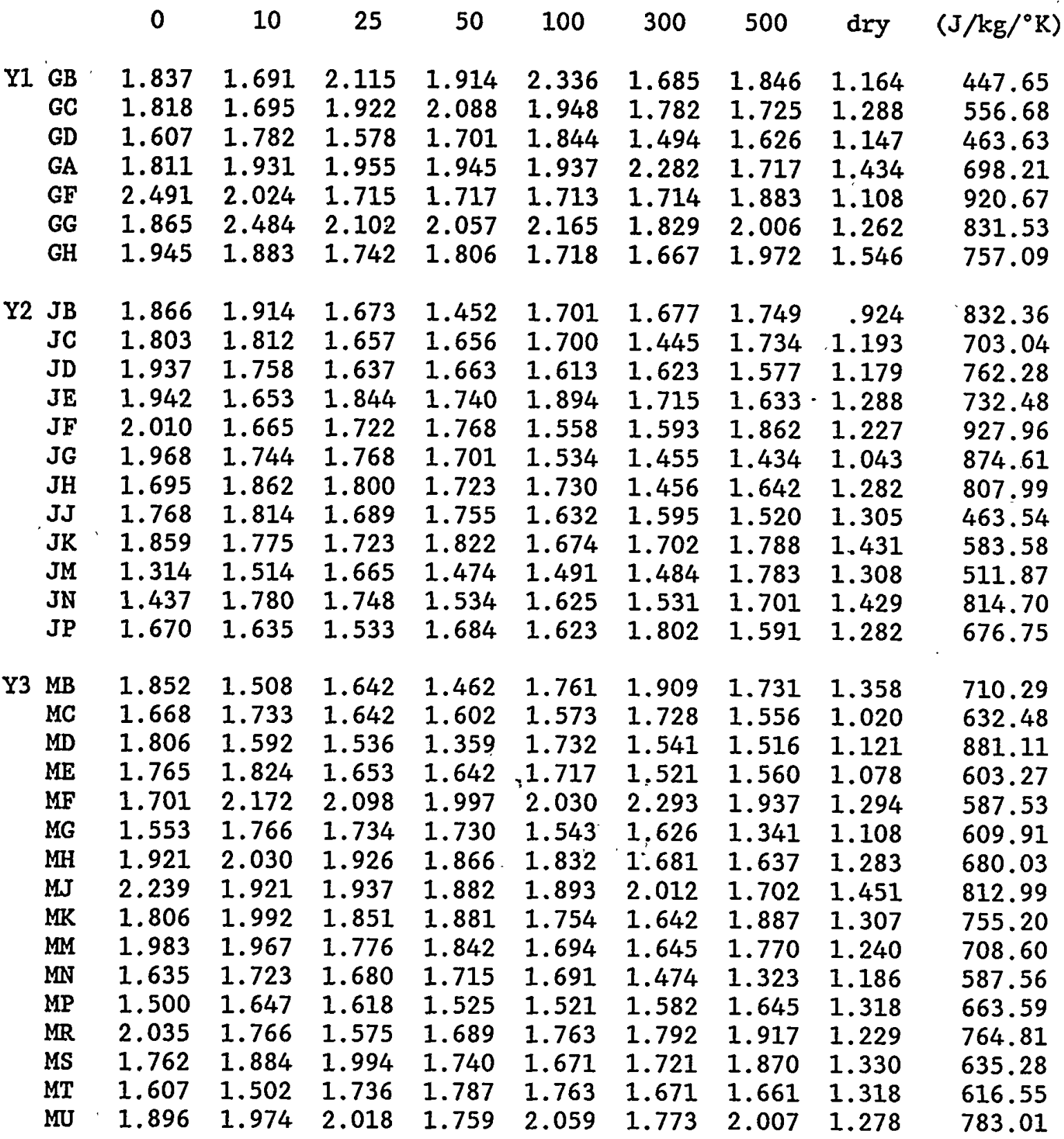

Dry Rock Specific Heat 
Table Al7 (Continued)

- . . . . . . . -

THERMAL CONDUCTIVITY $\left(\mathrm{J} / \mathrm{m} / \mathrm{s} /{ }^{\circ} \mathrm{K}\right)$

ID

$\mathrm{Z1}$

$21 \mathrm{~PB} \quad 1.932$

PC 1.836

PD 1.775

PE 1.901

PF 1.859

PG $\quad 1.600$

$\mathrm{PH} \quad 1.774$

$\mathrm{Z2} \mathrm{SB}$

SC

SD

$S E$

SF

SG

SH

SJ

SK

SM

SN

SP

$23 \mathrm{UW}$

UC

UD

UE

UF

UG

UH

UJ

UK

UM

UN

UP

UR

US

UT

UU
1.820

1.929

2.033

1.819

1.955

1.291

1.659

1.763

1.991

1.885

1.841

1.595

$1.552 \quad 1.843$

1.886

1.539

1.847

1.926

1.577

1.603

1.782

2.014

1.940

1.618

1.611

1.362

1.571

1.741

1.902
1.653

1.770

1.893

1.957

1.809

1.591

1.733

1.935

1.809

1.808

1.747

1.584

1.713

1.830

1.844 suction $(\mathrm{kPa})$

1.703

1.923

1.623

1.938

1.681

1.609

1.995

50

1.400

1.917

1.473

1.650

1.631

1.545

1.983

100

300

1.854

1.788

1.658

2.184

1.932

1.722

1.828

1.934

1.647

1.944

1.672

1.757

1.546

2.030

1.663

1.868

\subsection{6}

1.785

1.779

1.788

1.559

1.893

1.676

1.667

1.864

1.471

1.364

1.761

1.606

1.749

1.382

1.488

1.464

1.569

1.639

1.692

2.443

2.261

1.766

1.722

1.961

1.945

1.897

1.730

1.704

1.744

2.020

1.941

2.028

1.783

1.672

1.628

1.737

1.782

$1.814 \quad 1.611$

1.817

1.697

1.608

1.754

1.505

1.900

1.640

1.704

1.578

1.491

1.858

1.677

1.730

1.604

1.740

1.570

1.687

1.802

1.961

1.704

1.710

1.572

1.521

1.816

1.813

1.809

1.911

1.949

1.719

1.780

1.815

1.913

1.819

1.899

1.606

1.510

1.870

2.036

1.941

1.863

2.057

1.704

1.749

1.714

1.977

1.578

1.696

1.808

1.594

1.755

1.905

1.515

1.941

1.7201 .634

1.766

2. 402
1.608
1.816

1.960
Dry Rock

Specific Heat

500 dry $\left(\mathrm{J} / \mathrm{kg} /{ }^{\circ} \mathrm{K}\right)$

$1.819 \quad 1.368$

$1.714 \quad 1.199$

$1.736 \quad 1.160$

$\begin{array}{ll}1.715 & 1.321\end{array}$

$1.730 \quad 1.301$

$1.591 \quad 1.127$

$1.794 \quad 1.064$

$1.881 \quad 1.313$

$1.699 \quad 1.364$

$\begin{array}{ll}1.684 & 1.338\end{array}$

$\begin{array}{ll}1.575 & 1.207\end{array}$

$1.843 \quad 1.151$

1.095

.829

1.684

1.145

1.7721 .256

1.627

1.330

1.596

1.392

1.248

$1.284 \quad 1.178$

$1.697 \quad 1.451$

1.569

1.281

$1.680 \quad 1.386$

$1.705 \quad 1.235$

$1.841 \quad 1.192$

$1.579 \quad 1.167$

$1.504 \quad 1.100$

$1.643 \quad 1.333$

$1.637 \quad 1.304$

$1.742 \quad 1.304$

$1.669 \quad 1.402$

$1.410 \quad 1.350$

$1.494 \quad 1.166$

$1.759 \quad 1.185$

$1.615 \quad 1.217$

$2.044 \quad 1.287$

813.14

962.41

893.94

797.72

1043.5

1037.7

728.54

832.19

588.45

683.39

793.15

713.16

600.20

501.12

903.52

511.48

946.67

820.72

757.07

684.52

714.16

437.31

662.24

851.96

538.89

469.63

917.89

921.40

619.63 
Table A18: Field observed temperatures, ${ }^{\circ} \mathrm{C}$, in Borehole Y3 for various dates.

Borehole

ID

OBSERVED TEMPERATURES $\left({ }^{\circ} \mathrm{C}\right)$

Y3 M

MC

$\mathrm{MD}$

ME

MF

MG

$\mathrm{MH}$

MJ

MIK

MM

MN

MP

MR

MS

MT

MU

Borehole

ID

$\mathrm{YB}$
$\mathrm{MC}$
$\mathrm{MD}$
$\mathrm{ME}$
$\mathrm{MF}$
$\mathrm{MG}$
$\mathrm{MH}$
$\mathrm{MJ}$
$\mathrm{MK}$
$\mathrm{MM}$
$\mathrm{MN}$
$\mathrm{MP}$
$\mathrm{MR}$
$\mathrm{MS}$
$\mathrm{MT}$
$\mathrm{MU}$

$$
\text { 2/11/87 }{ }_{4 / 22 / 87}{ }_{7 / 28 / 87} 8 / 18 / 87 \quad 12 / 18 / 87
$$
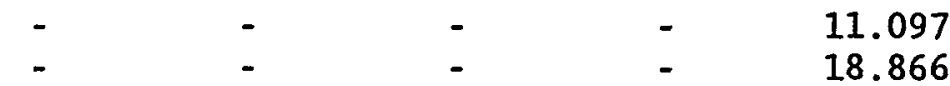

16.574

18.953

16.361

-

18.866

19.422

17.748

34.533

-

25.792

20.814

26.559

21.552

19.192

18.549

18.627

18.784

19.106

19.053

19.189

18.460

18.819

18.968

19.135

19.269

18.686

18.927

19.237

19.062

19.063

19.136

19.207

19.276

$\begin{array}{lllll}19.491 & 19.559 & 19.360 & 19.343 & 19.416 \\ 19.586 & 19.508 & 19.430 & 19.430 & 19.496\end{array}$

$\begin{array}{lllll}19.491 & 19.559 & 19.360 & 19.343 & 19.416 \\ 19.586 & 19.508 & 19.430 & 19.430 & 19.496\end{array}$
-

22.036

21.227

20.052

19.348

19.086

19.043

19.087

19.145

19.215

19.283

19.351 $\begin{array}{lllll}19.491 & 19.559 & 19.360 & 19.343 & 19.416 \\ 19.586 & 19.508 & 19.430 & 19.430 & 19.496\end{array}$

$\begin{array}{lllll}19.491 & 19.559 & 19.360 & 19.343 & 19.416 \\ 19.586 & 19.508 & 19.430 & 19.430 & 19.496\end{array}$

OBSERVED TEMPERATURES $\left({ }^{\circ} \mathrm{C}\right)$.

2/10/88 $3 / 23 / 88 \quad$ 5/19/88 $7 / 13 / 88 \quad 9 / 20 / 88$

16.029

28.932

32.862

31.876

28.818

15.772

17.143

20.837

25.422

28.165

19.149

18.520

19.176

21.272

24.283

20.761

19.833

19.369

19.816

21.471

20.507

20.198

19.744

19.631

20.211

19.983

20.024

19.868

19.687

19.811

19.630

19.755

19.792

19.707

19.673

19.491

19.590

19.685

19.665

19.663

19.463

19.527

19.611

19.613

19.649

19.503

19.537

19.591

19.599

19.627

19.575

19.596

19.628

19.615

19.661

19.642

19.659

19.683

19.660 .

19.684

19.710

19.735

19.759

19.727

19.737

19.781

19.822

19.842

19.791

19.818

19.815

19.881

19.947

19.850

19.863 


\begin{tabular}{|c|c|}
\hline $\begin{array}{l}\text { U.S. NUCLEAR REGULATORY COMMISSION } \\
\text { BIBLIOGRAPHIC DATA SHEET } \\
\text { (See instructions on the reverse) }\end{array}$ & $\begin{array}{l}\text { 1. REPORT NUMBER } \\
\text { (Asslgned by NRC, Add Vol., Supp., Rov., } \\
\text { and Addondum Numbers, if any.) }\end{array}$ \\
\hline \multirow{4}{*}{$\begin{array}{l}\text { Unsaturated Fractured Rock Characterization Methods } \\
\text { and Data Sets at the Apache Leap Tuff Site }\end{array}$} & NUREG/CR-5596 \\
\hline & DATE REPORT PUBLISHED \\
\hline & $\begin{array}{l}\text { MONTH } \\
\text { August } \\
\end{array}$ \\
\hline & $\begin{array}{l}\text { 4. FIN ORGRANT NUMBER } \\
\text { D] } 662\end{array}$ \\
\hline \multirow{2}{*}{$\begin{array}{l}\text { 5. AUTHOR(S) } \\
\text { T.C. Rasmussen, D.D. Evans, P.J. Sheets and J.H. Blanford }\end{array}$} & 6. TYPE OF REPORT \\
\hline & 7. PERIOD COVERED (Inc/usive Dates) \\
\hline \multicolumn{2}{|c|}{$\begin{array}{l}\text { 8. PERFORMING ORGANIZATION - NAME AND ADDRESS III NRC, provide Division, Office or Region, U.S. Nuclear Regulatory Commission, and mailing address: if contractor, provide } \\
\text { name and maillng addressi }\end{array}$} \\
\hline \multicolumn{2}{|c|}{$\begin{array}{l}\text { Department of Hydrology and Water Resources } \\
\text { College of Engineering and Mines } \\
\text { University of Arizona } \\
\text { Tucson, AZ } 85721\end{array}$} \\
\hline \multicolumn{2}{|c|}{$\begin{array}{l}\text { 9. SPONSORING ORGANIZATION - NAME AND ADDRESS IIf NRC, type "Same as above"; if contractor, provide NRC Division, Office or Region, U.S. Nuclear Regulatory Commission, } \\
\text { and malling dddress.) } \\
\text { Division of Engineering } \\
\text { Office of Nuclear Regulatory Research } \\
\text { U.S. Nuclear Regulatory Commission } \\
\text { Washington, DC } 20555 \text {. }\end{array}$} \\
\hline \multicolumn{2}{|l|}{ 10. SUPPLEMENTARY NOTES } \\
\hline \multicolumn{2}{|l|}{ 11. ABSTRACT (200 words or less) } \\
\hline \multicolumn{2}{|c|}{$\begin{array}{l}\text { Performance assessment of high-level nuclear waste containment feasibility } \\
\text { requires representative values of parameters as input, including parameter } \\
\text { moments, distributional characteristics, and covariance structures between } \\
\text { parameters. To meet this need, characterization methods and data sets for } \\
\text { interstitial, hydraulic, pneumatic and thermal parameters for a slightly welded } \\
\text { fractured tuff at the Apache Leap Tuff Site situated in central Arizona are } \\
\text { reported in this document. The data sets include the influence of matric suction } \\
\text { on measured parameters Spatial variability is investigated by sampling along } \\
\text { nine boreholes at regular distances } \\
\text { segments are provided, as weil as field estimates centered on the intervals where } \\
\text { the core segments were collected. Merasurement uncertainty is estimated by } \\
\text { repetitively testing control samples: }\end{array}$} \\
\hline \multirow[t]{6}{*}{ 12. KEY WORDS/DESCR!PTORS (List words or phrases that will assist resesrchers in locating the reporz.) } & $\begin{array}{l}\text { 13. AVAILABILITY STATEMENT } \\
\text { Unl imited }\end{array}$ \\
\hline & 14. SECUAITY CLASSIFICATION \\
\hline & $\begin{array}{l}\text { (This Page) } \\
\text { Uncl assified } \\
\text { (This Report) }\end{array}$ \\
\hline & \\
\hline & 15. NUMBER OF PAGES \\
\hline & 16. PRICE \\
\hline
\end{tabular}

